\title{
SUBCONTRATAÇÃO COMO INSTRUMENTO DE VIOLAÇÃO AO PRINCÍPIO DA PROIBIÇÃO AO RETROCESSO SOCIAL
}

\author{
Dissertação de Mestrado apresentada à Banca \\ Examinadora da Faculdade de Direito da \\ Universidade de São Paulo como requisito \\ parcial à obtenção do título de Mestre em \\ Direito, sob a orientação do Professor Doutor \\ Paulo Eduardo Vieira de Oliveira.
}

FACULDADE DE DIREITO DA UNIVERSIDADE DE SÃO PAULO

São Paulo - 2013 
Autorizo a reprodução e divulgação parcial deste trabalho, por qualquer meio convencional ou eletrônico, para fins de estudo e pesquisa, desde que citada a fonte. 
Nome: GEORGIA PATRIGNANI CALDATTO PIOVESAN

Título: Subcontratação como instrumento de violação ao princípio da proibição ao retrocesso social

Dissertação apresentada à Faculdade de Direito da Universidade de São Paulo como requisito parcial à obtenção do título de Mestre em Direito.

BANCA EXAMINADORA:

Prof.(a) Dr.(a):

Instituição:

Julgamento:

Assinatura:

Prof.(a) Dr.(a):

Instituição:

Julgamento:

Assinatura:

Prof.(a) Dr.(a):

Instituição:

Julgamento:

Assinatura: 
Dedico este trabalho à memória de minha bisavó materna, Durvalina de Souza Coelho, que, com sua altivez e humildade, soube me ensinar, ao longo dos vinte e três anos em que esteve presente em minha vida, os conceitos de força, determinação, fé e coragem. 


\section{AGRADECIMENTOS}

Árdua é a tarefa de agradecer a todas as pessoas que participaram desta longa caminhada até a conclusão do presente trabalho, pois é grande a possibilidade de que me olvide de alguém, embora tão importante quanto aqueles que aqui menciono. Contudo, é digno de nota que este trabalho é resultado da somatória do esforço pessoal e de incontáveis amigos, professores e colegas de trabalho. Necessário, entretanto prazeroso, expressar minha sincera gratidão, especialmente:

- À minha mãe, Silvia Maria Patrignani, que, demonstrando seu amor incondicional, sempre me considerou vencedora, mesmo diante dos obstáculos e percalços enfrentados.

- Ao meu marido, André Charles Bruschi Piovesan, pela paciência e inestimável incentivo concedidos durante os três anos desta pesquisa, coadunando comigo, ademais, nas teorias de distribuição de igualdade e justiça por mim empreendidas nesta pesquisa.

- Ao meu orientador, Prof. Dr. Paulo Eduardo Vieira de Oliveira, pelo compartilhamento do precioso tempo, pelas lições que me foram conferidas, pela demonstração do que é lecionar com amor e segurança, pela compreensão e, acima de tudo, por acreditar no meu trabalho e esforço.

- Ao Prof. Dr. Manoel Carlos Toledo Filho, professor e inestimável amigo, que reconheceu em mim, despretensiosamente, alguém que poderia realizar um bom trabalho tomando lições nesta Faculdade. Seus ensinamentos, lições compartilhadas, livros emprestados e incontáveis diálogos foram imprescindíveis ao resultado que ora se demonstra.

- Ao Prof. Dr. Jorge Luiz Souto Maior, fonte de inspiração; de quem um dia gostaria de seguir os passos, tanto em sua brilhante carreira acadêmica como de magistrado, na qual demonstra inabalável coragem, sabedoria e, sobretudo, senso de justiça.

- À irmã que escolhi, minha grande amiga Tábata Gomes Macedo de Leitão, que me incentivou ao desbravamento da pesquisa, à persistência na luta e me presenteou com a sua companhia incondicional, que mudaram, para sempre, a pessoa que sou.

- Aos amigos e colegas de trabalho, Salvador Eugênio Junior e Pedro Alexandre Matsu Martins da Silva, que, comprometidos com o aprimoramento deste trabalho, iluminaram meu caminho fornecendo-me ensinamentos valiosos sobre método, pesquisa científica, filosofia e sociologia.

- À Dra. Antonia Regina Tancini Pestana, Desembargadora Federal do Trabalho, que, com amor maternal, auxiliou-me pessoalmente nos momentos mais difíceis desta batalha. 
- Aos demais amigos e colegas de trabalho do Gabinete do Tribunal Regional do Trabalho da $15^{\text {a }}$ Região da Dra. Antonia Regina Tancini Pestana - pessoas iluminadas pela paciência em ouvir-me falar, a todo tempo da hora do café diário, deste trabalho e também pelo recorrente incentivo, em nome de Veridiana Pieroni, Naira Brasil, Filipe Fernandes, Raquel Ramos, Bruno Hiroshi e Maria Angélica Pinaud. 
"A gente vai contra a corrente Até não poder resistir." Roda Viva - Chico Buarque 


\section{RESUMO}

Esta pesquisa tem por escopo analisar de modo crítico o fenômeno da subcontratação à luz do pós-positivismo e dos princípios sociais que, inexoravelmente, incidem e lastreiam as normas de direito do trabalho. Para tanto, pretende-se proceder à análise das técnicas de produção introduzidas no Brasil na década de 80, em especial o "toyotismo", verificando se acaso configuraram novas formas de exploração do trabalho humano; isto é, se, de fato, caracterizam forma de precarização das condições de trabalho, colidindo com o a evolução histórica dos direitos e garantias individuais e coletivos. Tais constatações, por certo, ensejam estudos ainda mais específicos, como a responsabilidade da empresa principal nos casos de subcontratação, o desenvolvimento dos direitos sociais e dos direitos humanos no contexto global e mesmo a hermenêutica decorrente do influxo entre realidade e previsão normativa - consolidada pela jurisprudência pátria e regional. De fato, a conclusão pretende ser instrumento de auxílio aos profissionais do direito, da filosofia, da sociologia e de áreas afins, de forma que se possa posicionar de modo contundente e coerente a respeito da subcontratação enquanto fenômeno contemporâneo da sociedade brasileira.

Palavras-chave: Subcontratação; relações de trabalho; responsabilidade; princípios; pós-positivismo. 


\begin{abstract}
The purpose of this work is to analyze critically the phenomenon of subcontracting on the perspective of post-positivism and social principles that inexorably focuses and embases the rules of labor law. Therefore, it is intended to analyze the production techniques introduced in Brazil in the 80s, notedly the "Toyotism", checking if they're new forms of exploitation of human labor; if, in fact, characterize a way of precarious working conditions, colliding with the historical evolution of the individual and collective rights and guarantees. These findings certainly have inspired even more specific studies, such as the main company's responsibility in case of subcontracting, the development of social rights and human rights in the global context and even hermeneutics arising from the influx of reality and normative forecast - consolidated by brazilian and regional jurisprudence. In fact, the conclusion is intended to be a tool to aid professionals, scholars, workers, operators and researchers of law, philosophy, sociology and related fields, so they could stand more forceful and coherent about the subcontracting phenomenon in the contemporary Brazilian society.
\end{abstract}

Keywords: Subcontracting; work relationship; responsability; principles; postpositivism. 


\section{SUMÁRIO}

INTRODUÇÃO

1. Subcontratação .................................................................................................................................14

1.1. Descentralização produtiva: fordismo, taylorismo e toyotismo ....................................................14

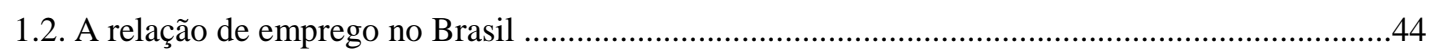

1.3. Flexibilização e globalização ...............................................................................................53

1.3.1. Paradoxo flexibilização e criação de novos empregos ...........................................................55

1.3.2. Flexibilização versus desregulamentação ........................................................................61

1.4. Subcontratação: conceito e delimitação ………………..........................................................69

1.4.1 Precarização das condições de trabalho e o dano social .....................................................73

1.4.1.1 Precarização ...............................................................................................73

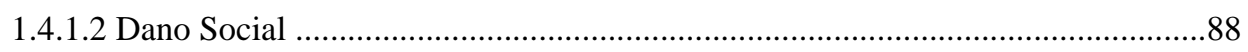

2. Análise jurídica da subcontratação - responsabilidade do subcontratante ...................................98

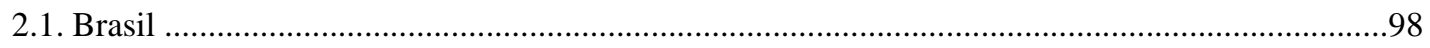

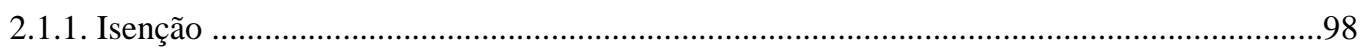

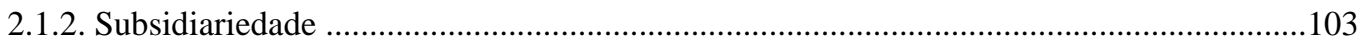

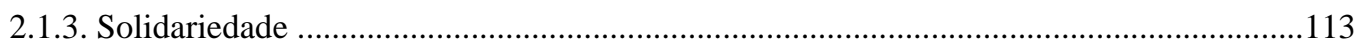

2.1.4. Vínculo de emprego - subordinação estrutural e reticular ..................................................118

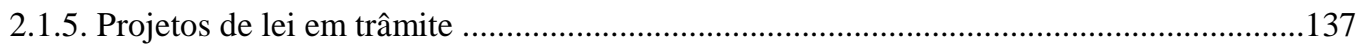

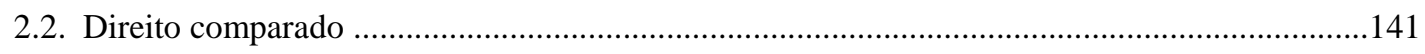

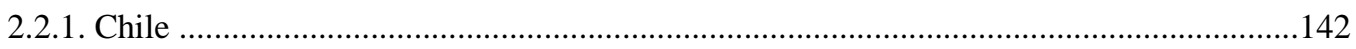

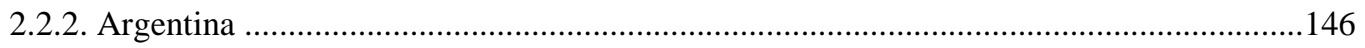

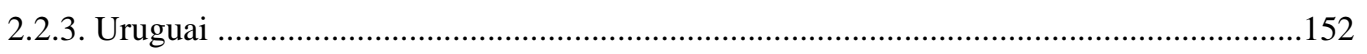

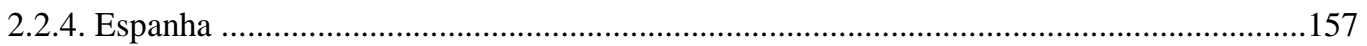

3. O princípio constitucional da proibição ao retrocesso social ...............................................................164

3.1. Crise e nova hermenêtica constitucional ..............................................................................164

3.2. Conceito e função dos princípios: o princípio como norma ......................................................180

3.2.1. O princípio da proibição ao retrocesso social ...............................................................189

3.2.2. O princípio justrabalhista da proteção e sua intersecção com o princípio da proibição ao retrocesso social ......................................................................................................199

4. Considerações finais: Subcontratação como instrumento de violação ao princípio da proibição ao retrocesso social

Referências bibliográficas .............................................................................................................................229

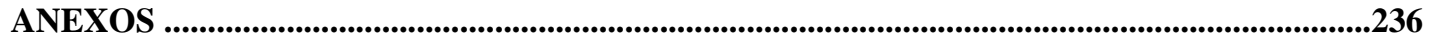




\section{INTRODUÇÃO}

O presente trabalho insere-se no contexto científico do empirismo e da teoria, de modo que se trabalha, ao final, a intersecção entre a subcontratação, objeto derivado da prática trabalhista, e a proteção aos direitos sociais, incluídos como princípios de constitucionais, pesquisa esta de caráter teórico.

Outrossim, o tema está dentro da linha de pesquisa da área de Direito do Trabalho da Faculdade de Direito da Universidade de São Paulo - "Direitos Sociais no contexto dos direitos humanos", considerando-se os projetos acadêmicos desenvolvidos pelos docentes, em especial - "A eficácia dos institutos, normas e princípios de direito interno, comunitário e internacional do trabalho e a efetivação dos direitos humanos."

O contexto é estabelecido pela existência de uma prática de mercado que se convencionou denominar por terceirização, e que logo tornou-se instituto jurídico objeto de estudo por diversos juristas, além de estar sob a análise da mais alta corte trabalhista diuturnamente.

Da terceirização, como será analisado deriva a subcontratação, a qual entendemos pela transferência, por uma empresa chamada principal, ou subcontratante, de uma parte de sua linha produtiva, fato que derivou de uma técnica de produção industrial revolucionária (do ponto de vista das ciências administrativas), que propugnava uma série de mudanças, dentre elas, a necessidade de se fabricar com menos, a produção enxuta.

A partir de então, a fábrica outrora conhecida nos moldes fordistas, organizada como de maneira vertical, com a produção e o desenvolvimento de todos os produtos e serviços dos quais necessitasse, passa a sofrer um processo de descentralização e pulverização.

Com isso, passa a adquirir características horizontais e segmentadas; cada nicho produtivo é transferido agora para uma outra empresa, cuja roupagem formal é completamente distinta daquela que a originou. A empresa principal passa a desvincular-se de todo o seu chão de fábrica, passando a explorar apenas o capital que se gera de sua marca. 
Exemplo do que será demonstrado é o caso da fábrica de chocolates NESTLÉ que subcontratou com exclusividade - vale salientar - a produção de chocolates da pequena empresa OFICINA DO CACAU.

No primeiro capítulo - Subcontratação - tem-se como escopo o estudo da história do desenvolvimento industrial brasileiro, a ocorrência da descentralização produtiva, a relação de emprego no Brasil e os impactos que veio a sofrer tal relação a partir da introdução das novas técnicas em questão.

De outra forma, busca-se, igualmente, analisar os impactos causados pelas formas de descentralização da produção, cominadas com os ideais flexibilizatórios advindos da globalização na relação de emprego e na sociedade como um todo, sob uma perspectiva crítica de redução/exclusão de direitos.

No capítulo segundo - Análise jurídica da subcontratação - responsabilidade do contratante - observa-se a existência de um instituto não regulamentado pelo direito brasileiro, mas cuja prática demandou manifestação do Poder Judiciário que hoje ainda busca construir-se.

\footnotetext{
Neste esteio, analisa-se as diversas formas pelas quais transita o direito no que tange à responsabilidade desta empresa que outrora mantinha uma relação de emprego estável, e que, a partir de novas técnicas de produção, passou a extirpar de seu estabelecimento os postos de trabalho (não apenas os trabalhadores), passando o serviço indispensável, mediante contratos civis, a empresas subcontratadas. Nessa perspectiva, analisa-se a isenção de responsabilidade, a subsidiariedade, a solidariedade e a decretação do vínculo de emprego, mediante a revisitação do conceito de subcontratação.
}

Para o fim de se auxiliar nessa empreitada, buscamos o estudo do direito comparado, que analisa, sob o viés doutrinário e legal - já que apresentam diplomas expressos - a disciplina do instituto da terceirização. Para a consecução deste objetivo, utilizamos os ordenamentos dos países do Mercosul - Chile, Argentina e Uruguai além da Espanha, que, via de regra, apresenta estudos jurídicos consolidados sobre o objeto. 
Por fim, no terceiro capítulo - o princípio constitucional da proibição ao retrocesso social - visa-se, finalmente, realizar a intersecção entre ambas as pesquisas, ou seja, a realidade hoje vivenciada com a introdução de novas técnicas produtivas e a consequente descentralização empresarial, que culminou na realidade da subcontratação, e a sua validade técnica em face dos princípios constitucionais e protetivos do direito do trabalho.

Nas considerações finais, analisa-se a subcontratação a partir da perspectiva do princípio constitucional de vedação do retrocesso social, constante do caput do art. $7^{\circ}$, da CLT, bem ainda sob o novo enfoque hermenêutico dado à Constituição da República, em especial sua normatividade. 


\section{SUBCONTRATAÇÃO}

\subsection{A descentralização produtiva e a subcontratação - do taylorismo ao toyotismo}

Para se cumprir com a finalidade de chegar à descentralização produtiva, decorrente dos modelos de reestruturação produtiva ocorridos no final do século XX no Brasil, inicialmente necessário analisar os modelos de produção taylorista e fordista, que fundamentaram a indústria brasileira em seus primórdios e que se complementaram no chão de fábrica ${ }^{1}$.

O taylorismo, também conhecido como "administração científica do trabalho", surge das ideias de Frederick Taylor, que a partir de sua experiência como operário em uma indústria siderúrgica, passa a observar os trabalhadores a seu redor, seus movimentos, o tempo de trabalho e a produtividade.

Uma vez que se alia a ciência à produção, o capital faz o máximo para extrair dos operários sua capacidade física e mental, como afirma Maria da Graça Druck:

\footnotetext{
Para alguns estudiosos, o taylorismo representa um tipo de mecanização sem a introdução da maquinaria; ou seja, trata-se de "subsumir o trabalho ao capital", através da expropriação do conhecimento dos trabalhadores, o que pode ser viabilizado através do controle efetivo do capital sobre o trabalho, realizado na forma da "gerência científica" e que tem como um dos fundamentos centrais a separação entre o trabalho manual e o trabalho intelectual.
}

Advém, então, de seus estudos, uma nova cultura industrial, que revolucionou o chão fabril, na transição do século XIX para o século XX, nos Estados Unidos.

Em suma, há a clara inserção pelo capital de divisão e de organização do trabalho baseados em uma hierarquia e disciplina fabris que culminaram na máxima subordinação do operariado, inclusive com o controle psicológico mediante técnicas de persuasão e do controle emocional do trabalhador. ${ }^{2}$

\footnotetext{
${ }^{1}$ Atribui-se o período de esfacelamento dos modelos fordista-taylorista de produção, no Brasil, os anos 80-90, com a introdução dos novos padrões toyotistas de produção. Vide, para tanto, DRUCK, Maria da Graça. Terceirização: (Des)Fordizando a fábrica - um estudo do complexo petroquímico da Bahia. Tese de Doutoramento, UNICAMP, Campinas: 1995, p. 36-37.

${ }^{2}$ HARVEY, 1992, p. 119, apud DRUCK, Maria da Graça, Op. Cit., p. 37.
} 
Para o próprio Taylor ${ }^{3}$, seu método de controle dos operários buscava otimizar o trabalho de modo que se visava:

(...) assegurar o máximo de prosperidade ao patrão e, ao mesmo tempo, o máximo de prosperidade ao empregado." Para o empregador, isto significa obter grandes dividendos, desenvolvimento de seus negócios. Para o empregado, além de salários mais altos, há um fato de maior importância: “... o aproveitamento dos homens de modo mais eficiente (...)

Certo é, todavia, que acredita o autor que os trabalhadores devam produzir incessantemente, sem deliberadamente trabalhar devagar, ou "fazer cera"; devem empregar todos os seus esforços durante o período de labor, para a consecução desta finalidade, o que, contudo, não ocorre. Para ele, os operários demonstram vadiagem no trabalho, de forma generalizada, e, portanto, que deveria ser combatida.

Depreende-se de suas afirmações o cenário fabril que se estava vivenciando um cenário de resistência à implantação desta nova forma de gestão, ocasionando diversas mobilizações operárias, de forma intensificada, notadamente nas décadas de 10 e 20 do século XX.

Druck nos fornece ótimo exemplo dessa resistência:

Na metalurgia, por exemplo, os trabalhadores realizaram várias greves contra a desqualificação, o controle do tempo pelo cronômetro e o sistema de pagamento por prêmios. Além disso, reivindicaram o reconhecimento, por parte dos patrões, da representação na fábrica, dos "comités de empresa".

Isso porque a implementação da eficiência, por meio da parcelização, da divisão de tarefas e do controle do tempo de trabalho (com o conseguinte aumento do ritmo de produção), ocasionavam o completo esgotamento do operariado, que não via a contraprestação ser agregada; seus salários continuavam baixos; seus direitos, mínimos.

Junto com o tolhimento de suas capacidades de reflexão por meio da aludida persuasão racional e da exploração máxima de sua força de trabalho, também procurava

\footnotetext{
${ }^{3}$ TAYLOR, 1987, p. 31, apud DRUCK, Maria da Graça, Op. Cit., p. 38.

${ }^{4}$ Op. Cit., p. 40.
} 
o método reforçar a alienação do trabalhador do contexto em que estava inserido, estabelecendo clara divisão entre a execução do trabalho e sua concepção.

Entretanto, a teoria taylorista somente poderia se desenvolver a partir da ausência de conflitos entre capital e trabalho, exigindo, portanto, uma postura de todos, empregados e patrão, no sentido de cooperar para o sucesso desta ciência do gerenciamento e, portanto, no aumento da produtividade.

E, nesse sentido, Taylor delineava certo autoritarismo em sua teoria, utilizando mais a força e a coerção para a implementação das novas técnicas produtivas, alijando ainda mais o trabalhador à sua efetiva integração no processo produtivo.

Surge, então, neste mesmo cenário, os métodos de Henry Ford, inserindo em sua fábrica de automóveis a linha de montagem e a especialização de cada trabalhador em uma determinada função, o que ficou fortemente retratado (e criticado) por Charles Chaplin na espetacular película "Tempos Modernos" (1936), que, contemporaneamente aos fatos, representa a alienação a que os trabalhadores estavam sendo submetidos.

O fordismo, inobstante sua larga concentração e desenvolvimento no início do século XX, é no período pós Segunda Guerra Mundial que definitivamente se instaura, nos EUA, com o objetivo de aumentar intensamente a produção industrial em um momento de reconstrução dos países europeus, devastados pela guerra. Foi, também, eminentemente, uma reação contrarrevolucionária empreendida pelos proprietários dos meios de produção às greves e lutas do proletariado, chancelando o estado de forças distintas que se estabeleceu com o taylorismo, apaziguando os ânimos de uma possível revolução e, ainda, introduzindo um novo modelo político no capitalismo, a socialdemocracia, ou o "Welfare State".

Durante o período do pós-guerra (1945) é que se consolida essa forma de produção e de acumulação de capital, na qual o mundo pode conhecer três décadas de crescimento econômico quase ininterrupto, ocasionado pelo próprio processo políticosocial desenvolvido ao longo dos anos, o que se chamou de "compromisso fordista", 
trazendo consigo a figura do "operário massa", transformando por completo o movimento operário até então visto.

O compromisso fordista se desenvolve no sentido do controle do operariado, que abandona o movimento de luta social em troca de seu reconhecimento como elemento da sociedade civil, inserindo-se nesta como seu efetivo membro ${ }^{6}$, o que permite à burguesia contornar os possíveis conflitos do capital e do trabalho e então chancelar seu plano de exploração da mão de obra de uma vez por todas: acumular capital.

Segundo Antunes, é nesta fase em que se extrai a mais-valia de forma mais extensiva, pois a linha de montagem estava desta forma consolidada ${ }^{7}$ :

\begin{abstract}
Uma linha rígida de produção articulava os diferentes trabalhos, tecendo vínculos entre as ações individuais das quais a esteira fazia as interligações, dando o ritmo e o tempo necessários para a realização das tarefas. Esse processo produtivo caracterizou-se, portanto, pela mescla da produção em série fordista com o cronômetro taylorista, além da vigência de uma separação nítida entre elaboração e execução. Para o capital, tratava-se de apropriar-se do savoir-faire do trabalho, "suprimindo" a dimensão intelectual do trabalho operário, que era transferida para as esferas da gerência científica. A atividade de trabalho reduzia-se a uma ação mecânica e repetitiva.
\end{abstract}

Nesse período de transição entre o Estado Mínimo para o Estado Intervencionista, forma-se a concepção do aludido Estado do Bem-Estar Social $^{8}$ ou "Welfare State", marcado pelo surgimento dos ideais social-democratas, de assistência e seguridade-social ${ }^{9}$ :

Este representa a garantia de sua "seguridade social" em sua qualidade de gestor geral da relação salarial: é o Estado que fixa o estatuto

\footnotetext{
${ }^{5}$ BIHR, Alain. Da grande noite à alternativa: o movimento operário europeu em crise. (trad. Wanda Caldeira Brant) 2 ed., São Paulo, Boitempo Editorial: 2010.

${ }^{6}$ MARX, Karl. Contribuición à la critique de la philosophie hégélienne du droit, tomo III, p. 396, apud BIHR, op. cit., p. 38.

${ }^{7}$ ANTUNES, Ricardo. Os sentidos do trabalho: Ensaio sobre a afirmação e a negação do trabalho. $2^{\mathrm{a}}$ ed., São Paulo: Boitempo, 2009, p. 39.

${ }^{8}$ Afirma Lenio Luiz Streck que o Brasil não passou pela fase do Estado do Bem-Estar Social, de maneira que as consequências da minimização do Estado para os países que passaram por essa política são diversas das apresentadas pela nação, passando esta diretamente para o Estado Neoliberal. In STRECK, Lenio Luiz. Jurisdição constitucional e hermenêutica. 2 ed., Rio de Janeiro: Forense, 2004, p. 61.

${ }^{9}$ BIHR, Alain. Op. Cit., p. 55.
} 
mínimo de todo assalariado (pelo direito do trabalho, pela definição de uma norma de consumo irredutível); é ele que impulsiona a conclusão e garante o respeito aos contratos coletivos; é ele que gere direta ou indiretamente o "salário indireto". Desde então, o proletariado ocidental pode deixar de considerar o Estado como um órgão puramente repressivo a serviço apenas dos capitalistas, para nele ver o instrumento do "bem coletivo".

O fordismo surge, portanto, como um novo modelo de organização capitalista de manutenção de poder sobre o proletariado pela concessão de benefícios de ordem da seguridade social, consolidando-se o denominado "compromisso fordista".

De forma ambígua, o compromisso fordista proporciona à classe proletária algumas de suas reivindicações na medida em que isso lhe possibilita integrar-se à sociedade civil, não se importando, mais com o fato de ser explorado, contanto que assistido, funcionando, assim, como um sistema fajuto de reconhecimento do trabalhador como cidadão, permitindo seu maior controle, sob todos os aspectos. Neutraliza-se, por conseguinte, os possíveis conflitos no chão das fábricas, e, da mesma forma, potencializa a exploração operária, pelo próprio fato de lhe conceder benefícios.

Essa exploração dá-se de forma silenciosa, de modo que o saber e a habilidade operários são monopolizados pelo capital, ocasionando um maior processo de alienação, trazendo aos operários uma sensação de dependência do trabalho.

Exemplo marcante do apoderamento burguês sobre o operariado é o depoimento do operário europeu, Charly Boyadjian, empregado em uma fábrica de calçados onde se trabalha em três turnos de oito horas, 48 horas em seis dias da semana, que declara esta sujeição:

"você ainda encontra facilmente voluntários para trabalhar aos domingos. Tenho certeza que, em certos momentos, se lhes pedissem para trabalhar sete dias da semana durante o ano todo, no limite, a coisa teria funcionado... E ainda tinha gente que trabalhava depois, 'por fora', por alienação, ou às vezes, por necessidade, além dos seus próprios turnos. Quando se trabalha 48 horas por semana, entende, a grana vira o truque, a coisa atrás da qual você corre... Um cara me dizia, gozando (mas sempre tem algo se sério na coisa): "Eu, quando estou de folga, não sei o que fazer, me enche o saco. Melhor eu ir pro 
trampo." A fábrica é tua vida. Quando você tá no batente, de certa forma você está seguro, não tem de fato mais nada pra fazer, tudo está arrumado pra você, você não tem de verdade nenhuma iniciativa. Você tem um pouco mais de grana, então vai comprar um monte de troço, o que puder, você vai comprar qualquer tranqueira. Você corre atrás do dinheiro e no fim, ele não serve pra grande coisa. Não te faz ganhar tempo, essa grana, você acaba perdendo de monte: pra ganhar, vamos dizer, dez minutos num troço que você faz todos os dias, vai perder uma hora por dia no trampo para pagar a coisa, é uma loucura. Mas, no fim, você está satisfeito com a coisa. É de fato a segurança, você não tem mais responsabilidade, é quase uma regressão infantil. Funciona com qualquer um: eu, antes de entrar nessa empresa, eu era militante, politicamente 'avançado', portanto, mas eu caí igualmente na mesma armadilha."10

O que se observa é que o fordismo, com o seu incrível compromisso, tenta (e consegue) modelar o estilo de vida do operariado, ultrapassando as fronteiras da fábrica, onde lhe impõe o ritmo alucinante de trabalho, fazendo inserir no inconsciente de cada um o verdadeiro espírito capitalista - o trabalho não mais era instrumento para garantir a cada um o que é necessário, mas sim para possibilitar um sistema de consumo desenfreado, supérfluo, incutido e manipulado pelo próprio sistema.

Tal situação levou a reforçar ainda mais os ideais democratas, os quais o capital se empenhava para inserir na classe trabalhadora, entretanto, foi justamente com essa tentativa de que surgiu também a figura do "operário massa"; designação relativa às condições de aglomeração urbana em que viviam os operários outrora vitimados por um processo de desenraizamento de suas origens, vez que se tratavam de migrantes e imigrantes. Tal circunstância, entretanto, também criou condições de união e consciência de classe ${ }^{11}$.

Esse agrupamento, como resposta às condições periclitantes de trabalho a que era submetido o operariado, levou à derrocada das lutas de classe, as quais anunciavam

\footnotetext{
${ }^{10}$ GORZ, André. Metamorfoses do Trabalho: Busca do Sentido, Crítica da razão econômica, trad. Ana Montoia, Ed. Anna Blume, p. 118. Recomenda-se a leitura para um olhar marxista mais aprofundado acerca da exploração da mais-valia decorrente do trabalho industrial, as transformações dos indivíduos em seres individualistas e consumistas, a criação mercadológica de necessidades de consumo, a inserção de valores materiais acima dos morais e a completa transformação do trabalho para o sucesso dos objetivo capitalista do aumento crescente e infindável da taxa de lucro, ainda que os seres humanos sejam apenas meios para isso.
} 
as primeiras rachaduras do compromisso fordista, ou seja, de que este operariado não mais se contentava apenas e tão somente com o que o Estado do Bem-Estar Social lhes proporcionava, uma vez que, em contrapartida, a exploração de sua mão de obra se intensificou de sobremaneira.

Desta forma, possível afirmar que o sistema de produção fordista-taylorista vigorou fortemente, principalmente nos Estados Unidos e na Europa, até os anos 60, quando começou a apresentar seus primeiros sintomas de crise, uma vez que o modelo de acumulação proposto era incapaz de sobreviver por si só, dados os limites de absorção da produção pelo restrito mercado consumidor, o inchaço da força de produção e a eclosão dos movimentos de luta dos trabalhadores dentro das fábricas, culminando na queda da taxa de lucros dos fabricantes e o acúmulo de bens em estoque.

A luta do proletariado, que se manifestou sob diversas formas, como pelo absenteísmo, lentidão na produção (denominadas como "operações-tartaruga"), difusão do poder operário, dentre outras, anunciou o limite temporal do compromisso fordista.

Assim, nasceu o que foi denominado de "crise do trabalho"; a recusa de um trabalho alienante e a recusa do operário em fazer do trabalho o centro de sua vida. A revolta, então, deu-se de duas formas, subvertendo-se a lógica da exploração pelo trabalho, sendo o denominador comum a fuga do trabalho e da produção pelo trabalhador: o absenteísmo e "turn-over" crescentes, busca de "pequenos trabalhos" ocasionais, e até mesmo a ruptura com a condição de assalariado e a volta às formas pré-capitalistas de produção, como o trabalho artesanal comerciante e familiar.

Outrossim, revigorou-se a luta pela reconquista de um poder sobre o processo do trabalho, com formas coletivas de pressão ao capital: greves parciais, ataques ao pessoal administrativo e à divisão capitalista do trabalho, formação de conselhos de oficinas e de conselhos de fábrica; difusão das palavras de ordem de autogestão, de controle e até mesmo de poder operário.

Simultaneamente ao movimento operário, que, em razão de sua organização e da falta de consciência de classe foi rapidamente controlado, do compromisso fordista

\footnotetext{
${ }^{11}$ BIHR, Alain, p. 57.
} 
eclodiu, em consequência alguns fatores essenciais, elencados por Alain Bihr, como a queda da produtividade, em razão da desorganização do processo do trabalho; desvalorização de elementos do capital constante, como a obsolescência acelerada e planificada; saturação do mercado, levando à uma contração das perspectivas de venda e a redução gradual da produtividade (que levou ao recrudescimento dos custos sociais, que anteriormente eram quase que gratuitos) ${ }^{13}$.

Não se pode olvidar, ainda, a crise do petróleo da década de 70, ocasionada pela elevação estratosférica de seu preço bruto - decorrente do embargo proposto pelos países membros da OPEP e do Golfo Pérsico à distribuição do petróleo aos Estados Unidos e à Europa -, provocando a primeira recessão generalizada após a Segunda Guerra, a qual também culminou no aumento brutal do desemprego e a contração do comércio mundial.

Interessante demonstrar que no Brasil, após atingir seu ápice, o padrão de acumulação capitalista de cariz desenvolvimentista, baseado nos modelos industriais implementados pelo governo Kubitschek de aceleração do crescimento, este experimentaria, a partir de 1974, seu declínio, que se manifestaria abertamente nos anos 80 .

É possível indicar, apenas a título de síntese, que a crise do capitalismo industrial no Brasil, que surgiu a partir de 1973, foi também, como aponta o Prof. Giovanni Alves $^{14}$

a crise de um padrão de industrialização capitalista centrado na expansão do Departamento III - o setor de bens de consumo duráveis (automóveis, eletrodomésticos, etc.). Desse modo, uma crise capitalista que não passa, de imediato, pelo esgotamento do padrão de organização do trabalho intensivo baseado nos princípios tayloristafordista. Mesmo no decorrer dos anos 80, a metamorfose da superexploração do trabalho iria garantir, sob diversas formas, elevados patamares de lucratividade, articulando padrões tayloristasfordistas no interior do novo paradigma industrial.

\footnotetext{
${ }^{12}$ Expressão mercadológica da língua inglesa, sem tradução literal adequada para a finalidade do tema, cujo sentido técnico está na alta rotatividade de empregados em um mesmo cargo.

${ }^{13}$ BIHR, Alain. Op. Cit., p. 69-73.
} 
O incrível aumento da industrialização no país centrou-se nos setores de bens de consumo duráveis, e, tal como ocorreu a partir dos anos 50, exigia a importação de bens de produção dos países capitalistas centrais.

Tal fato, inevitavelmente, implicaria na necessidade de meios internacionais de pagamentos (no caso, dólares norte-americanos), que seriam adquiridos pelo endividamento externo, propiciados pela liquidez do mercado internacional nos anos 60 e 70. O limite da industrialização hipertardia brasileira era posto em cheque, pela sua condição de dependência à lógica do capital internacional.

Outrossim, no período de 68 a 73, não é demais destacar, a expansão das importações de bens de capital cresceu muito mais do que a produção interna brasileira, ocasionando a tradicional crise da balança comercial de pagamentos.

Tais fatores em conjunto levaram à redução da taxa média de lucro das empresas, fazendo com que os mercados ocidentais se inserissem novamente em uma acirrada competição internacional, movida pelo fenômeno mais intensificado da globalização, já que seu mercado interno não mais representava fonte lucrativa de exploração, vez que atingido seu limite.

Neste sentido, o capital novamente não deixaria de responder à crise, tratando logo de reorganizar seu ciclo produtivo. Nesse contexto se iniciou uma mutação no interior do padrão de acumulação, aliado à globalização, visando alternativas que conferissem maior dinamismo ao processo produtivo, que então dava claros sinais de esgotamento. Gestou-se a transição do padrão taylorista e fordista anterior para as novas formas de acumulação flexibilizada.

O Prof. Ricardo Antunes ${ }^{15}$ nesta conjuntura ressalta:

Foi, entretanto, no contexto do salto tecnológico posterior (primeira resposta às lutas sociais radicais no interior do espaço fabril), que as forças do capital conseguiram reorganizar-se, introduzindo novos problemas e desafios para o mundo do trabalho, que se viu, a partir de então em condições desfavoráveis. (...)

\footnotetext{
${ }^{14}$ ALVES, Giovanni. O novo (e precário) mundo do trabalho - reestruturação produtiva e crise do sindicalismo. Boitempo, 2010, p. 109-110.

${ }^{15}$ ANTUNES, Ricardo, Os sentidos... Op. Cit., 2009, p. 46-49
} 
Foi nesse contexto que o toyotismo e a era da acumulação flexível emergiram no Ocidente, com processo de reestruturação, visando recuperar seu ciclo produtivo e repor sua dominação social.

A intensidade de trabalho outrora baseada na produtividade elevada aos máximos limites físicos humanos, da produção em série e massificada, dá lugar à flexibilização da produção, pela "especialização flexível”, por novos padrões de busca de produtividade, por novas formas de adequação da produção à lógica do mercado. Verificam-se novas modalidades de controle da produção por meio de instrumentos que a tornou mais barata e adaptável, diferentemente da concentração outrora observada.

Tem-se, então, a desconcentração industrial; buscam-se novos padrões de gestão da força de trabalho, dos quais os Círculos de Controle de Qualidade (CCQs), a "gestão participativa", a busca da "qualidade total", são expressões visíveis não só no mundo japonês, mas em vários países de capitalismo avançado e do Terceiro Mundo industrializado, já que na nação do sol nascente, tais técnicas se mostraram eficazes e rentáveis.

O toyotismo, então, penetra, mescla-se ou mesmo substitui o padrão fordista dominante, em várias partes do capitalismo globalizado, tendo como forte aliado o sistema de computadores, utilizado em escala progressiva, o que faz tornar as antigas tecnologias completamente obsoletas, determinando, portanto, a sobrevivência ou a queda de uma organização empresarial.

Segundo o Prof. Giovanni Alves ${ }^{16}$,

trata-se da compreensão do surgimento de uma nova lógica de produção de mercadorias, novos princípios de administração da produção capitalista, de gestão da força de trabalho, cujo valor universal é constituir uma nova hegemonia do capital na produção, por meio da captura da subjetividade operária pela lógica do capital.

E, para tanto, não raro se recorre à divisão de mercados, ao desemprego, à divisão global do trabalho, ao capital volátil, ao fechamento de unidades, à reorganização financeira e tecnológica ou então à denominada liofilização (pulverização) organizativa, baseada na eliminação, transferência, terceirização e 
enxugamento de unidades produtivas ${ }^{17}$, do que se ressalta a subcontratação ora estudada.

O modelo, baseado na criação do engenheiro da fábrica de automóveis Toyota, Taiichi Ohno, deve refletir o modelo da empresa enxuta, ou seja, que reduz ao máximo suas perdas em todas as atividades de trabalho, inclusive às relacionadas ao próprio trabalho.

Os engenheiros americanos Jeffrey Liker e David Meier, treinados no modelo japonês da Toyota, que se incumbiram de trasladar as melhorias para as empresas americanas que trabalhavam, identificaram algumas dessas perdas - superprodução, de modo que produzir antes ou mais do que o necessário significa aumentar os custos com pessoal, armazenagem e transporte; espera (tempo à disposição) dos empregados, ficando à espera de um movimento de uma máquina para realizar seu trabalho; transporte ou transferência, ou seja, a movimentação em si de materiais, peças, mesmo que a curta distância; superprocessamento, ou a inserção de movimentos a mais em uma determinada peça, de forma desnecessária, que podem produzir defeitos ou ainda peças em qualidade superior à desejada; deslocamentos desnecessário dos trabalhadores, como para empilhar peças, procurar ferramentas, etc; defeitos e sua correção (retrabalho) e não-utilização da criatividade dos funcionários. Perda de tempo, ideias, habilidades, melhorias e oportunidades de aprendizagem por não envolver ou não escutar seus funcionários ${ }^{18}$.

$\mathrm{Na}$ indústria toyotista, segundo o modelo propagado no Japão, tem-se características peculiares de produção, como salientado. Sua produção, a fim de evitar desperdícios, é sempre vinculada à demanda, observando-se a heterogeneidade e a variedade na produção, conceito distinto da fábrica fordista, cuja produção era homogênea e massificada.

Observa-se que o modelo proposto, dessa forma, continua utilizando-se da maisvalia relativa, tentando extrair o máximo de produtividade do trabalhador, eliminando quaisquer tipos de movimentos físicos que não estejam relacionados à atividade exata

\footnotetext{
${ }^{16}$ ALVES, Giovanni. Op. cit., p. 31.

${ }^{17}$ ANTUNES, Ricardo, Op. Cit., 2009, p. 51-52.
} 
para a qual foi contratado. Espera-se, portanto, que o trabalhador fique por 8 horas de seu labor estático, realizando apenas e tão somente os movimentos aos quais está automaticamente obrigado a fazer, mas com a agregação de ser um empregado com diversas competências na produção.

O operariado é constituído não mais pela célula específica taylorista; possui empregados multitarefas, treinados e com habilidades diversas para operar diferentes tipos de maquinários e atuar em diversas funções (inclusive, ao mesmo tempo, se necessário). Os procedimentos trazidos pelo sistema merecem ser explicados, uma vez que se constituem de novo padrão utilizado pelas fábricas adaptadas, e que geram como consequência direta uma necessária reestruturação produtiva.

Neste sentido, tem-se o "Just in Time", ou seja, um melhor aproveitamento do tempo de produção, onde o maquinário, as ferramentas e as peças estão alocados em um sentido de minimizar o dispêndio desnecessário de tempo em atividades que não agregam valor, como a movimentação do operário para acessar o maquinário, as ferramentas e as peças.

O aproveitamento da produção também se relaciona ao Kanban, método de organização de estoque, que muito embora se observe sua utilização nos supermercados norte-americanos no ano de 1962, foi difundido de acordo com o toyotismo, com seu uso racional na estocagem das fábricas.

O Kanban, sistema de placas utilizadas para a reposição das peças é fundamental, à medida que se inverte o processo de reposição do estoque: é o final, após a venda, que se inicia a reposição de estoques, e o Kanban é a senha utilizada que alude à necessidade de reposição das peças/produtos. Daí o fato de, em sua origem, o Kanban estar associado ao modelo de funcionamento dos supermercados, que repõem os produtos, nas prateleiras, somente depois da venda ${ }^{19}$.

A fim de se manter os padrões de qualidade, a fábrica no modelo toyotista implementa em seu âmbito de produção o sistema CCQ (Círculos de Controle de Qualidade), que é constituído por grupos de trabalhadores que são levados pelo capital,

\footnotetext{
${ }^{18}$ LIKER, Jeffrey K. e MEIER, David. O modelo Toyota: Manual de Aplicação. Trad. Lene Belon Ribeiro, Porto Alegre: Bookman, 2007, p. 52-54.
} 
a partir de um sistema de inserção do empregado na estrutura de comando, a discutir seu trabalho e desempenho, com vistas a melhorar a produtividade. Tal sistema converte-se em um importante instrumento para o capital apropriar-se das habilidades intelectual e cognitiva do trabalho.

A indústria toyotista, outrossim, disseminando o padrão enxuto da produção, inaugura o sistema horizontal, uma evidência que se refletirá em novos padrões jurídicos, já que os direitos dos trabalhadores aparentam estar sendo flexibilizados.

Diferentemente da verticalização fordista, que supunha o completo processo de produção e serviços dentro de seu âmbito empresarial, na medida em que as fábricas ampliaram as áreas de atuação produtiva, no toyotismo tem-se uma horizontalização, reduzindo-se o âmbito de produção e estendendo-se às subcontratadas, às terceiras, a produção de elementos básicos, que no fordismo são atributos das próprias fábricas, à exemplo das montadoras norte-americanas, cujo padrão fordista as guiou até a inserção dos novos parâmetros, nos anos 70. A horizontalização da produção, contudo, provoca uma onda inconteste de desempregados, como se verificará.

Antunes alerta, entretanto, que o sistema toyotista supõe uma intensificação da exploração do trabalhador, quer pelo fato dos operários trabalharem simultaneamente com várias máquinas diversificadas, quer pelo ritmo e a velocidade da cadeia produtiva. Ou seja, presencia-se uma intensificação do ritmo produtivo dentro do mesmo tempo de trabalho ou até mesmo quando este se reduz ${ }^{20}$.

Da mesma forma, além das novas formas de trabalho, o capital precisou, para superar sua crise, reinventar o imperialismo, por meio da globalização - "a invasão dos mercados alheios”, como advertiu o Professor Márcio Túlio Viana - , de modo que foram se quebrando as barreiras até então existentes entre os países. ${ }^{21}$

Observa Gounet ${ }^{22}$, todavia, que outro ponto essencial do toyotismo é que, para a efetiva flexibilização do aparato produtivo, é também imprescindível a flexibilização

\footnotetext{
${ }^{19}$ ANTUNES, Ricardo. Adeus ao trabalho?, 7 ed., São Paulo: Cortez, 2000, p. 34.

${ }^{20}$ ANTUNES, Ricardo, Os sentidos... Op. Cit., 2009, p. 58.

${ }^{21}$ VIANA, Márcio Túlio. A proteção social do trabalhador no mundo globalizado, In: PIMENTA, José Roberto Freire et alii. Direito do Trabalho: evolução, crise, perspectivas. São Paulo: LTr, 2004, p. 155182 , p. 158.

${ }^{22}$ GOUNET, Thomas, 1991, apud ANTUNES, Ricardo, Op. Cit., 2000, p. 36.
} 
dos trabalhadores, além da extração da mais-valia e do completo apoderamento de seu ser. Trata-se também de se difundir direitos flexíveis, de modo a dispor desta força de trabalho em função direta das necessidades do mercado consumidor.

Vive-se, no universo das formas transitórias de produção, cujos desdobramentos são também agudos, no que diz respeito aos direitos do trabalhador. Estes são desregulamentados e flexibilizados, de modo a dotar o capital do instrumental necessário para adequar-se à sua nova fase. Diminui-se ou mescla-se, dependendo da intensidade, a produção taylorista, com o novo processo toyotista, pela inserção das técnicas de engenharia de produção acima delineadas.

Em razão dos processos renovadores, a fábrica se torna enxuta, a fim de tornarse competitiva, podendo produzir ao máximo com o mínimo dos fatores de produção.

E, como afirma o eminente Prof. Márcio Túlio Viana ${ }^{23}$, resumindo o mundo novo da fábrica toyotista e do fim das barreiras das nações:

\footnotetext{
A "terceirização" leva à "terciarização": no limite, a grande fábrica tende a se tornar simples gerenciadora, sem máquinas e sem operários. E a mesma razão que a faz "se enxugar" a impele a se desgarrar do território de origem, como se passasse de imóvel a móvel, sempre em busca de mão de obra barata, direitos flexíveis, sindicatos dóceis e políticas fiscais favoráveis.

Para vender, já não basta produzir. É preciso "produzir barato", para que se possa "vender barato", e ao mesmo tempo descobrir (ou inventar) novos "nichos para as ofertas: hoje uma lanterna que fala, amanhã um rádio que pisca. Não que o consumidor tenha se tornado mais crítico ou exigente: ficou apenas mais pobre, e nunca foi tão manipulável. A solução é criar - em ritmo de rock - novas vontades, que não se realimentam: o isqueiro musical exige míni-baterias...
}

O que se depreende é que a situação apresentada é constituída por problemas mais profundos que o da simples invenção de produtos e serviços supérfluos, mas principalmente, da criação dessas necessidades. O problema se torna de grande enfoque e que exige maior interferência quando afeta diretamente a força motriz da sociedade os trabalhadores. 
O novo modelo, que se intensificou na exploração do trabalho e iniciou uma nova forma de comércio e de produção, baseada na globalização e, portanto, no intenso volume de exportações, fez-se sentir também em solo brasileiro, mais fortemente a partir da década de 80, e trouxe consigo as mais diversas formas de flexibilização das condições de trabalho, o "novo subproletariado"24, como os terceirizados, subcontratados, trabalhadores em tempo parcial (part time), temporários, informalizados, dentre outros.

Trata-se de, nos termos de Francisco de Oliveira, da existência de meras ocupações $^{25}$, e não mais de empregos - grupos de jovens nos cruzamentos vendendo qualquer coisa, entregando propaganda de novos apartamentos, lavando/sujando vidros de carros a troco de moedas, ambulantes por todos os lugares. Os impactos sociais desse novo modelo, notadamente na classe trabalhadora, são cada vez mais degradantes.

Com a reestruturação produtiva no Brasil, especialmente a partir de 1990, ocorre uma intensa redução do contingente de operários industriais, com um corte de $38,1 \%$ dos empregos formais entre 1990 e $1997^{26}$.

Como ressalta Antunes $^{27}$, há o recrudescimento da heterogeneidade e a fragmentação da classe trabalhadora; a subcontratação segmenta ainda mais os trabalhadores industriais, entre os "centrais" e os "periféricos", vale dizer, entre aqueles que foram mantidos na indústria para o fim de permanecerem no trabalho colaborando com negócio central das empresas (com as garantias e benefícios da relação formal de trabalho), e aqueles que passam a prestar serviços para a fabricação de subprodutos que servirão àquela empresa, em condições mais precarizadas de trabalho, como se verificará na análise mais detida do fenômeno objeto de estudo.

Às transformações que passam a ocorrer no capitalismo industrial se atribui a denominação, portanto, de reestruturação produtiva, e é marcada por diversas mutações no universo do desenvolvimento do trabalho em um período notadamente composto

\footnotetext{
${ }^{23}$ VIANA, Márcio Túlio, Op. Cit., p. 160.

${ }^{24}$ ANTUNES, Ricardo. Os sentidos do trabalho, Op. Cit. 2009, p. 104.

${ }^{25}$ OLIVEIRA, Francisco de. Crítica à razão dualista/O ornitorrinco. São Paulo: Boitempo: 2011, p. 142.

${ }^{26}$ SANTOS, José Alcides Figueiredo. Estrutura de posição de classe no Brasil, mapeamento, mudanças e efeitos na renda, Belo Horizonte, Ed. da UFMG: 2002, p. 145, apud ANTUNES, Ricardo. O caracol e sua concha, 1 ed., São Paulo: Boitempo, 2011, p. 108.

${ }^{27}$ ANTUNES, Ricardo. O caracol..., p. 108.
} 
agora, primordialmente, pela mundialização, transnacionalização e financeirização dos capitais.

O que ocorre, por conseguinte, é a inteira fragmentação do proletariado ${ }^{28}$, que passa a se dividir claramente entre proletários estáveis e com garantias; agora, categoria esta restrita a uma pequena parcela da classe; os trabalhadores excluídos do trabalho, estando nesse último ramo aqueles condenados à margem da sociedade, ao desemprego de longa duração ou aos benefícios da seguridade-social, sem possibilidade de reenquadramento em novas funções e, por fim, os trabalhadores instáveis, onde estão todos aqueles vitimados pela flexibilização das condições de trabalho - o mencionado subproletariado.

Inobstante os fenômenos a que ora se atentam, interessante destacar que as mudanças se alastram para dentro da classe trabalhadora, inclusive; sua visão, como classe, é cindida, e os próprios trabalhadores passam não mais a se reconhecerem como pertencentes a um mesmo grupo como outrora, observando-se divisões dentro de um mesmo segmento social, o que agrava ainda mais o sentido de união do movimento operário - aquele que possui um cargo hierarquicamente superior, ainda que em situação de subordinação a outrem, não reconhece aqueles que detêm cargos de menor prestígio como companheiros de luta e, principalmente, de classe. Eis a fragmentação, que passará a ser característica do século XXI.

Nesse sentido, aponta o Prof. Giovanni Alves ${ }^{29}$, que o sucesso do sistema Toyota vincula-se, numa perspectiva histórica, às grandes derrotas da classe operária, a própria decapitação do seu "intelectual orgânico" no plano produtivo: o sindicato industrial, de classe, transformado num sindicato de empresa, corporativo e interlocutor exclusivo do capital, não mais dos interesses dos empregados.

Trata-se de um esfacelamento da representatividade, um processo de neutralização político-ideológica da classe operária no espaço da produção, tão importante para o sucesso do toyotismo que, no país capitalista de origem, o Japão, uma das passagens essenciais que asseguram a promoção dos dirigentes e a formação das elites da empresa Toyota é a atividade sindical.

\footnotetext{
${ }^{28}$ BIHR, Alain. Op. Cit. P. 83-84.

${ }^{29}$ Op. cit., p. 61.
} 
Junto aos reflexos na classe trabalhadora, vê-se ainda a completa transformação da fábrica, passando-se a inverter o sistema fordista de concentração outrora proposto, transformando-se, então, na "fábrica difusa" ${ }^{30}$ : a fábrica, outrora organizada como uma cidade, onde todos os produtos e serviços eram concentrados, em uma forma verticalizada, passa a se descentralizar e a se externalizar, mediante processos como os de terceirização e subcontratação, com o objetivo de eliminar seus custos fixos com o trabalho ${ }^{31}$.

Neste sentido, interessante ressaltar que enquanto na fábrica fordista aproximadamente $75 \%$ da produção de uma mercadoria era realizada em seu interior, na fábrica toyotista, em uma referência a uma estrutura vertical, apenas $25 \%$ da produção desta mesma mercadoria é assim realizada ${ }^{32}$.

A fábrica prioriza, portanto, o que é central (o "core business"), o que julga ser sua a especialidade no processo produtivo e transfere às empresas subcontratadas grande parte do que antes era produzido dentro de seu espaço produtivo. Esse fenômeno estende-se às subcontratadas, acarretando a expansão dos métodos e procedimentos para toda a rede de fornecedores.

E, neste sentido, como analisa $\mathrm{Bihr}^{33}$, obtém-se a nova estrutura produtiva da fábrica, em franco crescimento nos dias de hoje, privilegiando-se por completo a economia e o enxugamento das estruturas de produção:

A centralidade da grande indústria não é abolida: ela simplesmente se transforma. Em vez de concentrar em um mesmo lugar o máximo de funções produtivas e administrativas, o capital tende hoje, ao contrário, a espalhar a produção e o poder através de todo o espaço social. Pois a fábrica difusa supõe sempre uma unidade central que coordena, planifica, organiza a produção de toda uma rede de unidades periféricas, que podem atingir o número de várias centenas, e até de vários milhares. A concentração piramidal do poder é

\footnotetext{
${ }^{30}$ Como explica Bihr, essa expressão fora cunhada pelos estudiosos do proletariado italiano, a partir de uma análise de reestruturação dos grandes centros industriais da Itália do centro e do norte.

${ }^{31}$ Como bem coloca Ricardo Antunes, nem todo trabalhador assalariado é produtivo, no sentido de que são geradores de um antivalor no processo de trabalho capitalista. São, pelo que Marx denominou, "falsos custos", pois necessários para a sobrevivência do próprio sistema capitalista. ANTUNES, Ricardo. $O$ caracol ..., p.50-51

${ }^{32}$ ANTUNES, Ricardo, Os sentidos do trabalho, Op. Cit., 2009, p. 56.

${ }^{33}$ BIHR, Alain. Op. Cit. P. 87-88.
} 
substituída pelo poder resultante da gestão fluida e flexível de uma rede.

"Externalizar" uma parte das funções produtivas ou administrativas até então incluídas no campo organizacional da grande indústria. Trata-se da desconcentração e até mesmo da desaglomeração das grandes unidades produtivas, da descentralização de sua gestão (cujo controle pela matriz se torna possível graças ao desenvolvimento das redes de informática) e do desenvolvimento das filiais, de todos os movimentos que tiveram um belo impulso no curso desses últimos anos, sob a proteção do slogan "small is beautiful", e que não são de forma alguma contraditórios com uma centralização financeira maior do capital.

Este modelo, decorrente da citada reestruturação produtiva, fez com que se observasse no Brasil a citada liofilização organizacional, delineada pelos seguintes fatores determinantes ${ }^{34}$ :

a) a necessidade de as empresas brasileiras buscarem sua inserção na competitividade internacional;

b) as ações das empresas transnacionais que levaram à adoção, por parte de suas subsidiárias no Brasil, de novos padrões organizacionais e tecnológicos, em alguma medida inspirados no "toyotismo" e nas formas flexíveis de acumulação;

c) a necessidade das empresas nacionais responderem ao avanço do novo sindicalismo, que procurava estruturar-se mais fortemente nos locais de trabalho e que teve forte traço de confrontação, desde as históricas greves do ABC paulista, no pós-78.

Interessante destacar que o cenário econômico do Brasil no final da década de 80 e início da década de 90 se mostrou deveras favorável para o surgimento das práticas de terceirização, como já citado.

Contudo, as políticas de governo foram determinantes à deterioração do trabalho e ao estabelecimento de formas de exploração flexibilizadas. Juntamente a um período de debilidade do sindicalismo brasileiro, o governo Collor (1990-1993) introduziu as

\footnotetext{
${ }^{34}$ ANTUNES, Ricardo e SILVA, Maria A. Moraes (orgs.). O avesso do trabalho. 2 ed., São Paulo: Expressão Popular, 2010, p. 16.
} 
políticas neoliberais de abertura econômica, frente à globalização mundial, objetivando a inserção do país na competitividade externa.

Acompanhado do crescimento do desemprego na indústria nesta nova era, o país pode observar o crescimento da produtividade que, de 1991 a 1996, ascendeu em 132\%, alcançado à custa da produção enxuta (a força de trabalho diminuiu 25\%, entre 1989 e 1992, representando uma redução de 78.700 empregos), do Programa de Qualidade Total, "Just-in-time"/kanban e o uso abundante de horas extras ${ }^{35}$.

A partir de então, o país inicia a absorção dos conceitos toyotistas, reorganizando por completo sua produção industrial, que se baseou em sistemas como redução do número de trabalhadores, intensificação da jornada de trabalho dos empregados, novos sistemas relativos à economia de materiais e aumento da produtividade, dentre outros, sendo a consequência mais marcante para a economia a redução de custos no processo de trabalho, mais fortemente sentida nos setores produtivos automobilístico, de autopeças e têxtil, e no de serviços, como o bancário.

E os impactos para a indústria nacional são gritantes ${ }^{36}$ :

Se durante a década de 1970, segundo Pochmann (2000), no auge da expansão do emprego industrial, o Brasil chegou a possuir cerca de $20 \%$ do total dos empregos na indústria de transformação, 20 anos depois, a indústria de transformação absorvia menos de $13 \%$ do total da ocupação nacional.

Com a mudança da dinâmica industrial voltada para o mercado interno, dada a motivação dependente de maior inserção competitiva externa, a economia nacional começou a conviver, pela primeira vez desde os anos de 1930, com perda absoluta e relativa de postos de trabalho na indústria de manufatura. Entre as décadas de 1980 e 1990, por exemplo, a economia brasileira perdeu próximo a 1,5 milhão de empregos no setor de manufatura.

A eliminação dos postos de trabalho do chão de fábrica se transforma em máquinas de última geração, ou ainda, na alocação da força de trabalho em empresas

\footnotetext{
${ }^{35}$ POSTHUMA, Anne Carolina, 1993, apud ALVES, Giovanni, op. cit., p. 225.

${ }^{36}$ POCHMANN, Márcio. Nova divisão internacional do trabalho e as ocupações no Brasil, 2000, apud ANTUNES, Ricardo e SILVA, Maria A. Moraes, Op. Cit., p. 21.
} 
diversas, externas à sua estrutura física - mas ainda conexas por força de contratação para integração de sua produção, de onde nascerá a subcontratação - a transferência daquele nicho de produção a outra estrutura produtiva, mais enxuta, com um preço a ser pago por produção encomendada, muito inferior, portanto, à manutenção dos mesmos empregados em sua concentração produtiva.

Neste sentido, é comum haver a perfeita correspondência entre antigos empregados da indústria planificada com a nova - estes passam a laborar muito mais, por salários reduzidos, produzindo o mesmo, e em péssimas condições de higiene e segurança -, ou ainda, levada às últimas consequências, a designação de um exempregado como sócio ou diretor desta, a fim de se manter os mesmos padrões de produção de outrora, em patente método de precarização das condições de trabalho pelo barateamento do custeio da mão de obra e dos meios de produção.

E a descentralização produtiva propicia à fábrica, ademais, sua ampliação geográfica, porquanto sua estrutura produtiva se dissemina por um espaço desagregado, por diversas outras fábricas, viabilizando amplas reduções em seu quadro de pessoal, na busca cada vez maior de mão de obra mais barata, acentuando, assim, sua característica de instrumento de precarização das condições de trabalho.

E, para realizar a fábrica enxuta, o sistema toyotista de produção dá início à "fragmentação sistêmica ${ }^{37}$ " da indústria, constituindo as empresas redes, um dos exemplos mais notáveis do fenômeno da subcontratação.

A "fragmentação sistêmica" tem como principal característica a "externalização" de suas atividades produtivas. Instaura-se, a partir desse fenômeno, um novo patamar de flexibilidade e integração, tanto nas dependências da própria fábrica descentralizada como nas relações entre empresas clientes, e possibilitada pelas novas tecnologias de comunicação e informática.

E, como aponta o Prof. Giovanni Alves ${ }^{38}$,

Surge uma miríade de pequenas empresas, subcontratadas ou de fornecedores, em vários graus da cadeia produtiva, que instauram uma

\footnotetext{
${ }^{37}$ ALVES, Giovanni, op. cit., p. 57.

${ }^{38}$ Idem, p. 58.
} 
relação de longo prazo com a empresa central (o conglomerado ou corporação transnacional), cuja duração é determinada pelo ciclo do produto $^{39}$.

A externalização representa meios que permitem às corporações transnacionais estabelecer relações desiguais perante outras empresas - subcontratantes e fornecedores - e reforçar o seu próprio poder econômico, estabelecendo formas estáveis de dominação oligopolística, que foram afetadas pela nova crise do capital, a partir dos anos 70, pela passagem do oligopólio doméstico ao oligopólio mundial e pelas profundas mudanças tecnológicas.

Desse modo, a instauração da empresa-rede pelo toyotismo não significa, como aponta François Chesnais ${ }^{40}$

uma ruptura com as hierarquias e a internalização, mas antes uma nova forma de organizar e gerenciar essas hierarquias, bem como de maximizar as possibilidades de "internalizar" as "externalidades" (...) proporcionadas pelo funcionamento em rede.

O fenômeno apresentado compreende também imaginar algo que não se verificava em um passado recente - a criação de empresas virtuais, decorrentes da própria descentralização produtiva. As empresas se inserem um uma rede tão complexa de contratos e produção, que a principal acaba por se desfazer por completo de seus ativos fixos, propriedades e quaisquer bens, existindo apenas formalmente. Em contrapartida, possui margem de lucros estratosférica.

Um exemplo paradigmático da empresa virtual é a fabricante de calçados esportivos norte-americana Nike. A companhia estabeleceu uma ampla rede de provedores - produtores físicos de seus conceitos ideais, o que faz a empresa principal

\footnotetext{
39 Não seria demais observar que o advento da EIRELI - Empresa Individual de Responsabilidade Limitada - criada pela Lei Federal $\mathrm{n}^{\mathrm{o}}$ 12.441, de 11 de julho de 2011, possibilitou a incremento da subcontratação inclusive de pessoas físicas para participar de referida rede, sem a assunção, da subcontratante, pelos riscos inerentes à relação de emprego, desvencilhando-se formalmente, dos custos da mão de obra, mediante um contrato de natureza civil entre empresas. Referida lei, vale ressaltar, admite um capital social não inferior a 100 vezes o salário mínimo do país (art. $2^{\circ}$ ), capital este suficiente para empreendedores de natureza inclusive industrial.

${ }^{40}$ CHESNAIS, François. A mundialização do capital, São Paulo: Xamã, 1996, p. 109, apud ALVES, Giovanni, op. cit. P. 59.
} 
ser dona apenas das ideias e imagens, os bens de consumo - e de desejo - atualmente vendidos $^{41}$.

Também reflexo da reestruturação produtiva, a financeirização ${ }^{42}$ da riqueza sob a mundialização do capital é fenômeno crescente, por meio da qual o capital procura se valorizar cada vez mais, sem passar pelo complexo de produção de mercadorias, inclusive empreendendo técnicas de exploração da mão de obra por meio de empresas intermediárias, passando de produtor a um detentor de uma marca de consumo consolidada.

Com ela, conforme ensina o Prof. Giovanni Alves, "atingimos o último grau na fetichização das relações de propriedade capitalista", de acordo com os ensinamentos de $\operatorname{Karl} \operatorname{Marx}^{43}$ :

Com o capital que rende juros, a relação capitalista atinge sua forma mais externa, mais fetichizada. Temos aqui D - D', ou seja, dinheiro produzindo dinheiro, valor se valorizando por si só, sem nenhum processo que sirva de mediação entre os dois extremos.

É sob a mundialização do capital que assistimos, portanto, a vigência do capitalismo parasitário e rentista, multiplicando-se a partir de si mesmo, e não mais a partir da exploração de uma atividade industrial. E, é o desenvolvimento dessa lógica da financeirização que irá instaurar um novo perfil do toyotismo, depurando-o, em sua aplicação no ocidente, como técnica (e princípio) de manipulação universal do "trabalho vivo" subsumido à lógica do capital.

Trata-se de introduzir novas técnicas de exploração do trabalho, utilizando-se, ainda de novas tecnologias que possibilitam sua manipulação.

E, com tais técnicas, nota-se também a redução do número de trabalhadores constituintes da classe operária industrial, outrora instalada no complexo produtor de mercadorias. Contudo, não se trata de uma mera reposição de trabalhadores por máquinas, mas o incremento de sua expansão, dita pelo Prof. Giovanni Alves como

41 ROSENBAUM, Jorge e CASTELLO, Alejandro. Régimen Jurídico de la Subcontratación e Intermediación Laboral. Montevidéo: Fundación de Cultura Universitária, 2007, p. 23.

${ }^{42}$ ALVES, Giovanni. Op. cit., 61-62.

${ }^{43}$ MARX, Karl. O capital, Vol. I, 1983, apud ALVES, Giovanni, p. 62-63. 
"periférica", vale dizer, "interpenetrada por unidades de subcontratação industrial e de "serviços" (vale dizer, um neoproletariado "pós-moderno" com estatutos sociais precários $)^{44, \text {. }}$

E, para fins de demonstração da referida afirmação, o historiador Eric Hobsbawn $^{45}$ apresenta dados relativos ao período crítico da introdução das técnicas de acumulação flexível nos principais países de economia capitalista, movidos por políticas neoliberais:

Entre 1973 e fins da década de 1980, o número total de pessoas empregadas na manufatura nos seis velhos países industriais da Europa caiu 7 milhões, ou cerca de um quarto, mais ou menos metade dos quais entre 1979 e 1983. Em fins da década de 1980, enquanto as classes operárias nos velhos países industriais se erodiam e as novas surgiam, a força de trabalho empregada na manufatura estabilizou-se em cerca de um quarto de todo o emprego civil em todas as regiões desenvolvidas ocidentais, com exceção dos EUA, onde a essa altura estava bem abaixo de $20 \%$.

Nos países em desenvolvimento, em especial no Brasil, nos anos 80 a classe operária ainda mantém presença significativa nas indústrias. Contudo, como afirma o Prof. Alves ${ }^{46}$ :

em virtude da mundialização do capital, as empresas, conglomerados e corporações transnacionais no Terceiro Mundo, como é o caso da indústria automobilística, tendem a adotar, cada vez mais, em maior ou menor proporção, os mesmos padrões tecnológico-organizacionais do centro capitalista (...). O complexo de reestruturação produtiva que atinge o Terceiro Mundo tende a debilitar o mundo do trabalho, (re)constituindo - ou meramente extinguindo - pela desindustrialização, os polos de modernidade industrial, instaurados na época da industrialização emergente. Os imperativos da competitividade mundial exigem das corporações transnacionais, os verdadeiros agentes da mundialização do capital, seja nos países capitalistas centrais, seja nos países do Terceiro Mundo, uma lean

\footnotetext{
${ }^{44}$ ALVES, Giovanni, op. cit., p. 67.

${ }^{45}$ HOBSBAWN, Eric. Era dos extremos - o breve século XX, 1995, p. 299, apud ALVES, Giovanni, op. cit., p. 67-68.

${ }^{46}$ ALVES, Giovanni, op. cit., p. 69.
} 
production, que tende a conduzir à redução de pessoal empregado na indústria.

É na indústria automobilística, um dos principais setores industriais do capitalismo mundial, que surge, com maior plenitude, a natureza da crise de acumulação do capital na era da mundialização. Vale dizer, trata-se de uma crise que, apesar de a capacidade de produção ser bem maior que a necessidade de mercado, continua crescendo, principalmente nos países capitalistas emergentes - entre eles o Brasil.

Nesse contexto, o novo complexo de reestruturação produtiva significa não apenas a aceleração da adoção da automação microeletrônica na produção, mas a utilização das novas estratégias organizacionais, inspiradas na "lean production". Articulam nova flexibilidade da produção, não apenas no espaço do processo de trabalho dentro da empresa (ocasionando o surgimento de um novo perfil operário), mas, principalmente, na relação entre empresas, na qual se desenvolvem novas estratégias de descentralização produtiva, como a subcontratação.

Como afirma o Prof. Giovanni Alves ${ }^{47}$,

é nesse âmbito que surge algo fundamental na nova etapa da produção capitalista: uma nova logística da cadeia produtiva, cujo principal exemplo é a "terceirização", que vai permitir às corporações transnacionais do setor automobilísitico desenvolver novos laços de subcontratação, capazes de proporcionar um novo patamar de valorização. As novas plantas industriais das montadoras instaladas no país apresentam, no aspecto da organização da produção, novos tipos de flexibilidade, de estratégias de racionalização de custos, adequadas aos novos requisitos da produção vinculada às novas tecnologias da Terceira Revolução Industrial (por exemplo, o "consórcio modular", utilizado pela Volkswagen, em Resende/RJ e o "condomínio industrial", da General Motors, em Porto Alegre/RS).

Tem-se, portanto, a irrupção dos processos de descentralização produtiva, caracterizada principalmente pela deslocalização das fábricas, baseadas em um intenso processo de terceirização, principalmente a partir dos anos 90 no Brasil, levando à manifestação máxima do toyotismo, porquanto também leva à quebra da consciência de

${ }^{47}$ Idem, p. 182-183. 
classe, pela fragmentação do campo da produção de mercadorias, pulverizando a coletividade do trabalho.

E a terceirização acaba por envolver toda a fábrica, compondo não apenas as atividades que não exigem especialidade, mas também aquelas derivadas do próprio objeto de sua atividade, oferecendo uma divisão especializada do processo produtivo aliada à manutenção do nível tecnológico. É o que se observa, quando ocorre o aumento de transferência de atividades de manutenção, ferramentaria, estamparia, fornecimento de peças e subconjuntos, anteriormente realizados pelos operários da montadora da indústria automobilística, atividade que liderou o complexo de descentralização produtiva no Brasil. E, nesse contexto, diz-se, por exemplo, que o negócio das montadoras é montar automóveis, e nada mais do que isso.

E assim observa o Prof. Giovanni Alves ${ }^{48}$ acerca da descentralização produtiva, fincada na externalização do próprio processo produtivo:

\footnotetext{
A princípio, a terceirização promove a externalização da produção dos demais componentes necessários à produção do produto final. Os processos tipicamente produtivos passam a ser executados nas instalações da empresa subcontratada pela montadora, ou nas próprias instalações da montadora, que cede espaço e equipamento para que o fornecedor opere internamente em sua própria fábrica, como é o caso do consórcio modular ou do condomínio industrial. É uma nova (e radical) terceirização, que se caracteriza pela desverticalização total da empresa, criando uma rede de subcontratação com as empresas das quais passam a comprar o produto que antes produziam.
}

Exemplo maior do início do sistema da subcontratação como fenômeno da descentralização produtiva, a indústria automobilística inaugurou formas radicais de terceirização, denominadas por "consórcio modular" e "condomínios industriais, acompanhada, principalmente, da adoção de inovações tecnológicas da microeletrônica, que possibilitavam a substituição de trabalhadores por robôs.

Denomina-se o consórcio modular a estrutura industrial em que a empresa divide sua linha de montagem de acordo com a especialidade de fabricação de cada componente de seu produto final. Por exemplo, na Volkswagen da cidade de Resende 
(RJ), a linha é dividida em 7 módulos responsáveis por fases específicas do processo produtivo, as quais, por sua vez, tem correspondente um parceiro de fornecimento - o de motores, o de câmbio, chassi, etc.

Eles são os consorciados da VW, responsáveis, com seus próprios operários, por um módulo produtivo, no qual se realiza a montagem de conjuntos completos dos veículos, mas estão todos ligados a um "mestre" da subcontratante, ligado à atividade produtiva.

Trata-se de uma obsessão pela redução de custos, visando aproximar-se cada vez mais do modelo "keiretsu" ${ }^{49,}$ japonês. Nos "keiretsu", afirma Amaro Neto,

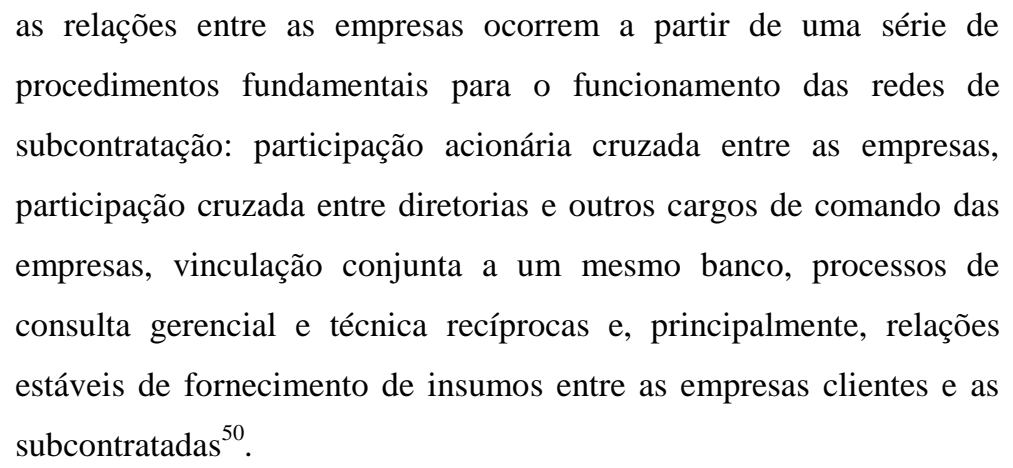

Instaura-se, portanto, uma nova hierarquia entre as empresas componentes da rede, de modo que se mantêm interligadas mediante contratos de fornecimento, mas que, ao mesmo tempo, se confundem em sua personalidade. Objetiva-se, ademais, a promoção, por meio de práticas empresariais de fusão, incorporação e do próprio fechamento das concorrentes, a redução do número de fornecedores, organizadas em níveis de cadeias de suprimento. Ao mesmo tempo, observa-se a padronização dos produtos fornecidos, repassando a estes industriais a tarefa de produzir subsistemas completos dos componentes do automóvel.

\footnotetext{
${ }^{48}$ ALVES, Giovanni. Op. Cit., p. 206.

49 processo de hierarquização das empresas subcontratadas pela corporação transnacional, In WATANABE, Ben apud ALVES, Giovanni, p. 220.

${ }^{50}$ AMARO NETO, J. Desintegração vertical/terceirização e o novo padrão de relacionamento entre empresas: o caso do complexo automobilístico brasileiro. São Paulo, USP, tese de doutorado, Escola Politécnica da USP, 1993, apud ALVES, Giovanni, op. cit., p. 211.
} 
Nesse sentido, interessante trazer à baila exemplo da montadora de veículos Volkswagen $^{51}$ :

Sob a experiência do consórcio modular, os parceiros da VW, por exemplo, comprometem-se a investir em equipamentos e instalações e a contratar a força de trabalho dedicada à produção de partes de um produto final - caminhões e ônibus - que é propriedade da corporação transnacional. O capital investido por cada consorciado VW fica dedicado, portanto, à produção dos módulos do veículo da marca VW. Eles se transformam numa espécie de "sócios" minoritários da VW. Não apenas fornecem peças e componentes dos veículos, mas dividem os riscos do investimento e vão ter maior participação nas decisões. Por exemplo, a VW só paga a peça colocada pelo fornecedor depois de vender o caminhão.

À empresa subcontratante caberá, portanto, a supervisão, a comercialização e a elaboração do projeto, aspectos eminentemente estratégicos da produção capitalista pósmoderna.

No condomínio industrial, por sua vez, à montadora caberá, ainda, a atividade de montagem do produto principal. No caso da Volkswagen, a esta ainda caberia a montagem final dos veículos, após o fornecimento de todas as peças componentes pelas empresas do aludido condomínio.

Em ambos os sistemas, contudo, objetiva-se a redução de custos com logística, uma vez que também se reduz substancialmente a distância geográfica entre as empresas da rede. Notório que há a transferência do risco do negócio aos parceiros empreendedores, cada um assumindo a parcela do componente industrial que produz, o que era, outrora, integralmente assumido na empresa verticalizada.

A pesquisadora Liana Carleial, ao estudar a subcontratação, realizou pesquisa empírica na região metropolitana da cidade de Curitiba (PR), apontando em sua análise a subcontratação nas industriais metalmecânica, eletroeletrônica e de confecções.

A amostra foi composta pelas oito empresas de maior faturamento, de acordo com os dados obtidos na Secretaria da Indústria e do Comércio do Estado do Paraná, em

\footnotetext{
${ }^{51}$ ALVES, Giovanni, op. cit., p. 218.
} 
seus gêneros industriais, empresas A, B, C, D, E, F, G e H. A partir de critérios de visita e entrevista, com ajuda de seus diretores, localizou-se suas subcontratadas: $A=3 ; B=3$; $\mathrm{C}=3 ; \mathrm{D}=3 ; \mathrm{F}=4 ; \mathrm{G}=3$ e $\mathrm{H}=6$, totalizando o montante de 25 empresas subcontratadas para um universo de oito subcontratantes ${ }^{52}$.

Tais empresas dividem-se em segmentos distintos da economia, sendo que as indústrias A, B e C são componentes do ramo da eletroeletrônica; as empresas D, E, F e G compõem o ramo da indústria metalmecânica (material de transporte) e a empresa $H$, por sua vez, participa do segmento das confecções.

Observou a pesquisadora, dentre uma gama de critérios de pesquisa, que quando se referem às vantagens da subcontratação, há similitude entre as respostas, qualificando a subcontratação/terceirização como um procedimento que permite a centralização das tarefas, o foco na atividade que é importante. E o importante é "manter as atividades que agreguem valor e não que agreguem custos": redução de investimentos em ativos, imóveis e a redução do custo da mão de obra; a natureza da flexibilização externa se torna mais nítida.

Diante deste quadro geral, a subcontratação/terceirização apresenta-se, nestas empresas, como uma estratégia casada de busca por liquidez (flexibilidade) e centralidade em atividades-chave (que se caracterizam como as de mais alto conteúdo tecnológico, desenho do produto, concepção, etc.) assentada, no entanto, na busca por redução dos custos, exigência inequívoca da concorrência.

E tais empresas alegaram descentralizar (terceirizar) as seguintes etapas de suas atividades ${ }^{53}$ :

\begin{tabular}{|l|l|}
\hline Etapas produtivas subcontratadas por diferentes indústrias \\
\hline Eletroeletrônica & Estamparia \\
& Ferramentaria \\
& Montagem de gabinetes \\
& Galvanização \\
& Usinagem \\
& Injeção de plásticos \\
& Montagem de cabos \\
& Montagem de cartão \\
\hline
\end{tabular}

52 CARLEIAL, Liana. Redes industriais de subcontratação - em enfoque de sistema nacional de inovação, São Paulo: Hucitec, 2001, p. 17.

${ }^{53}$ Op. Cit., p. 78. 


\begin{tabular}{|l|l|}
\hline Metalmecânica & Usinagem \\
& Tratamento térmico \\
& Carrocerias de madeira \\
& Eixos \\
& Caixas de manutenção \\
& Freios \\
\hline Confecções & Montagem \\
& Bordado \\
& Controle de qualidade \\
& Passadoria \\
& Embalagem \\
\hline
\end{tabular}

Verifica-se do quadro acima que as empresas subcontratantes externalizam as atividades que se confundem com seu próprio "core business", notadamente em razão de não se estabelecer um método eficaz de distinção das atividades essenciais da indústria. Nesse sentido, poderia facilmente indagar-se se à indústria de confecção seu "core business" também não é o da montagem da peça de roupa, ou ainda, do seu bordado; mais ainda, se na indústria metalmecânica a montagem e produção dos eixos não se constituiria sua atividade final ao mercado consumidor.

Em um primeiro momento, poderia se indagar que não se avista, na presente narrativa, qualquer problema para a livre iniciativa propugnada por meio da terceirização ora em exame, nomeadamente em razão da estratégia relacional de garantia de parceria industrial em vistas à sobrevivência no mercado, designando um relacionamento empresarial no qual todos os agentes se beneficiam em igualdade de condições.

Ocorre, todavia, que nem sempre se verifica a relação empresarial sadia entre as componentes da rede de subcontratação ${ }^{54}$, mas a prática espúria do único objetivo da redução dos custos, integrando-se uma típica estratégia de confronto entre operário e capital em razão da precarização de suas condições de trabalho, relação esta em que apenas um dos agentes da subcontratação leva vantagem, obtendo lucro a partir da descentralização de suas atividades a um baixo custo.

As indústrias modernas identificariam o primeiro modelo de terceirização apontado, tais como as indústrias do setor de autopeças do interior de São Paulo, onde

\footnotetext{
${ }^{54}$ Segundo Liana Carleial, a rede é uma estrutura relativamente informal na qual a coordenação das atividades é obtida pela confiança recíproca e a consciência mútua de um interesse comum. Op. Cit., p. 38.
} 
se verifica um tipo de terceirização associado a um esforço articulado entre a grande e a pequena empresa para qualificar fornecedores e aumentar a qualidade dos produtos.

Na segunda hipótese, contudo, são identificadas com maior predominância as indústrias de calçados de Franca, a indústria de confecções do Rio de Janeiro e as "senzalas da moda 55 ", de São Paulo, também do segmento da confecção - sendo comuns os denominados contratos de facção (espécie atípica que reúne elementos da terceirização de serviços e do contrato de empreitada) -, onde existem formas de combinação de fatores de inovação produtiva e o recrudescimento da precarização e instabilidade do emprego, como será verificado em item próprio sobre a referida precarização. Tais ramos, contudo, não são os únicos a lançar mão dessa técnica, de modo que se verifica verdadeiro avanço à flexibilidade do trabalho de forma generalizada na indústria brasileira.

Pode-se, a partir das pesquisas de Carleial, notar que a subcontratação, nesse contexto de precarização, favorece a criação de graus de dependência entre as empresas subcontratante e subcontratada, estas últimas que, em verdade, na maioria das vezes representam a existência de pseudo-empresas.

Neste sentido, constatou-se na pesquisa da autora que dentre as subcontratadas da metalmecânica (B), as pseudo-empresas. Uma delas não possui prédio próprio, bem como todo o maquinário, componentes e matérias-primas pertencem à empresa-mãe; não há qualquer autonomia com relação a esta última.

A rede $\mathrm{C}$ (eletroeletrônica) reúne um produtor de placa de circuito impresso e dois de chicotes elétricos.

A empresa C1 vende $90 \%$ de sua produção para C e seu faturamento depende na mesma proporção da mãe. Ademais, C1 tem todos os equipamentos que foram adquiridos da mãe, e localiza-se no mesmo espaço físico dela, em um galpão cedido. Tem todo o suprimento de matéria-prima e componentes também fornecidos pela empresa-mãe. Constituiu-se, vale mencionar, para atender exclusivamente à empresa $\mathrm{C}$.

\footnotetext{
${ }^{55}$ Referência dada pela Revista Época (Ed. Globo) em reportagem de 02/04/2011, que flagra a existência de condições de trabalho degradantes e análogas à escravidão em pequenas oficinas de costura na cidade de São Paulo, as quais servem a grandes marcas da indústria de confecção brasileira. Disponível em
} 
De acordo com a entrevista realizada pela equipe da pesquisadora na empresa C1, realizada com o diretor industrial, ex-funcionário de C, observou-se que este lá trabalhou lá por catorze anos e aceitou o empreendimento de assumir a direção de $\mathrm{C} 1$ 'porque considerou um grande desafio fazer essa empresa crescer'.

Contudo, sua condição na empresa C1 é precária; não é seu sócio, tem o mesmo salário que tinha em $\mathrm{C}$ mais a participação nos lucros. Desta forma, se $\mathrm{C} 1$ der mesmo certo, lhe será oferecida a participação na sociedade. C depende $100 \%$ da produção de $\mathrm{C} 1$, o que se justifica em razão da transferência total de sua produção para esta última. ${ }^{56}$

Nas demais indústrias a realidade não se difere em muitos aspectos.

É interessante retratar que D1 absorveu, da empresa D, 90\% de seus 130 trabalhadores ${ }^{57}$.

A empresa A3, da categoria dos fornecedores da empresa A (eletroeletrônica) forneceu mais um exemplo de dependência para com a empresa-mãe, uma vez que restou relatado pela pesquisadora que, parando os pedidos efetuados por esta última, toda a produção para, o que significa, decerto, sua falência ${ }^{58}$.

A partir da racionalidade acima apontada é que se desenvolve o presente estudo, perpassando a relação de trabalho no Brasil e sua degradação por meio das técnicas de reestruturação produtiva apontadas. É com a inserção de um enfoque jurídico que se verificará, adiante, a possibilidade de reversão do quadro social estabelecido, ocasionado pelos processos de reestruturação produtiva acima evidenciados.

\subsection{A relação de emprego no Brasil}

Inicialmente, para se perfazer o completo delineamento histórico da relação de trabalho no Brasil, até ser atingido o status atual da relação de emprego e das formas hodiernas de prestação de trabalho, mister essencial é percorrer por toda a história da prestação de trabalho no país, desde o uso da mão de obra indígena, do início do século XVI, até do imigrante europeu, para então se entender como o ranço histórico da

http://revistaepoca.globo.com/Revista/Epoca/0,EMI223067-15223,00.html, acesso em 15 de outubro de 2012.

${ }^{56}$ CARLEIAL, Liana, Op. Cit., p. 140.

${ }^{57}$ Idem, ibidem.

${ }^{58}$ Idem, p. 136-137. 
escravidão de outrora é ainda visível nas relações de poder, e como a dominação de classes sociais constitui-se de elemento ainda mais vivo no chancelamento das formas atuais de exploração da mão de obra.

Observada a riqueza e a fertilidade da terra brasileira, é com a introdução de medidas políticas de uso desta, por Portugal, que o trabalho no Brasil começa a ser efetivamente explorado, a fim de se desenvolver a expansão da indústria agrícola.

Iniciou-se, assim, o plantio do açúcar, onde se depararam os colonos com o primeiro problema relativo à mão de obra - trazê-la de Portugal demandaria despesas ainda maiores, haja vista que as exigências dos patrícios se consistiam em salários maiores do que os pagos em terras portuguesas, e a oferta de terras não representava, em contrapartida, grandes atrativos econômicos para assim procederem. A utilização de escravos africanos, já empreendida em terras europeias, não significava, neste primeiro momento, negócio viável para a colônia, uma vez que os custos de sua caça e importação ainda se faziam impossíveis de serem absorvidos pelos ganhos.

Assim, a utilização da mão de obra indígena tornou-se alternativa, iniciando-se no nordeste e no norte do país, e foi parte dos primeiros projetos de colonização. A captura e comércio do indígena vieram constituir a primeira atividade econômica rentável para aqueles que não se dedicaram à produção e ao comércio do açúcar.

E, como ressalta Celso Furtado ${ }^{59}$, "o fato de que desde o começo da colonização algumas comunidades se hajam especializado na captura de escravos indígenas põe em evidencia a importância da mão de obra nativa na etapa inicial de instalação da colônia”, denotando que, apesar do posterior insucesso do uso desta mão de obra na produção em grande escala da cana, servia-se a uma indústria particularmente rentável, se tornando, inclusive, condição de sobrevivência para a população que se expandiu no norte do país.

Séria e incisiva era, então a luta dos colonos para arregimentar a mão de obra indígena à época, o que foi veementemente combatido pelos jesuítas imigrantes.

\footnotetext{
${ }^{59}$ FURTADO, Celso. Formação econômica do Brasil. 34 ed., São Paulo, Companhia das Letras: 2007, p. 77.
} 
A posterior queda do comércio do açúcar pelo Brasil, em razão da entrada das Antilhas no comércio, com alta produção, e a dificuldade na captura e manutenção dos indígenas nas colônias, que facilmente se rebelavam, somada à introdução de certa diversidade agrícola que se mostrava útil e rentável, possibilitou a expansão da colônia agrícola e a introdução da mão de obra africana escrava para o trabalho.

Interessante considerar a afirmativa dos pesquisadores Calixto Salomão e Brisa Lopes $^{60}$ de que o trabalhador africano significava ao colono altos rendimentos em razão de sua extrema forma de exploração:

A expectativa média de vida extremamente reduzida dos escravos demonstra como, além de explorado ao máximo no trabalho, os gastos com sua saúde e alimentação eram descurados, sendo na verdade inferiores ao nível de subsistência. Como relata Blackburn, o preço relativamente barato pago pelos escravos e o enorme valor da mercadoria por ele produzida criou a lógica econômica desumana de esgotar a vida do escravo em poucos anos de trabalho intenso.

A relação criada entre a alta produção escrava e o quase inexistente custo de sua mão de obra assegurou, portanto, o próspero negócio da caça ao escravo negro e ainda o desenvolvimento progressivo da economia açucareira - conforme relata Celso Furtado ao terminar o século XVI, a produção de açúcar muito provavelmente superava os 2 milhões de arrobas, sendo umas vinte vezes maior que a cota de produção que o governo português havia estabelecido um século antes para a as ilhas do atlântico. ${ }^{61}$

A manutenção da mão de obra escrava africana durante os três séculos em que ocorreu, não se sucedeu, entretanto, sem maiores complicações. Revoltas, fugas e a formação de quilombos eram constantes, ao que lhes eram impingidos sérios e diversos castigos corporais, como relata a história:

Os castigos corporais são comuns, permitidos por lei e com a permissão da Igreja. As Ordenações Filipinas sancionam a morte e mutilação dos negros como também o açoite. Segundo um regimento de 1633 o castigo é realizado por etapas: depois de bem açoitado, o

\footnotetext{
${ }^{60}$ SALOMÃO FILHO, Calixto et alii, Concentração, estrutura e desigualdade: As origens coloniais da pobreza e da má distribuição de renda. São Paulo: Editado por Instituto de Direito do Comércio Internacional e Desenvolvimento (IDCID), 2008, p. 43.

${ }^{61}$ FURTADO, Celso. Op. Cit., p. 77
} 
senhor mandará picar o escravo com navalha ou faca que corte bem e dar-lhe com sal, sumo de limão e urina e o meterá alguns dias na corrente, e sendo fêmea, será açoitada à guisa de baioneta dentro de casa com o mesmo açoite.

Outros castigos também são utilizados: retalhamento dos fundilhos com faca e cauterização das fendas com cera quente; chicote em tripas de couro duro; a palmatória, uma argola de madeira parecida com uma mão para golpear as mãos dos escravos; o pelourinho, onde se dá o açoite: o escravo fica com as mãos presas ao alto e recebe lombadas de acordo com a infração cometida. ${ }^{62}$

Apesar dos grandes problemas enfrentados, a exploração do trabalho africano constituía-se de forma rentável para o desenvolvimento e expansão da colônia agrícola e, posteriormente, do ciclo do ouro no século XVIII, intensificando ainda mais sua busca no ciclo do café, no início do século XIX, quando, em 1808, em decorrência de acordos comerciais celebrados entre Portugal e Inglaterra, quedou-se proibido o tráfico negreiro. Somente muito depois, ainda, na segunda metade do século XIX que a mão de obra imigrante, "livre e assalariada", começou a ser introduzida em solo brasileiro.

De acordo com o Prof. Jorge Luiz Souto Maior ${ }^{63}$, prejuízos de toda a sorte trouxe a escravidão ao Brasil, notadamente para a formação social baseada na justiça social e na valorização do trabalho humano:

Essa situação legou à sociedade, como diz Luiz Felipe Alencastro (apud Pompeu, p. 64) "uma insensibilidade", uma espécie de descompromisso com a sorte das pessoas que se situam fora das classes mais favorecidas. Evidentemente que esse forte fator cultural influencia na abordagem do direito do trabalho, um direito que, por se preocupar com essa maioria desfavorecida, é desprezado e considerado como resultado indevido da intervenção fascista do Estado Novo.

A escravidão fundou a civilização brasileira e ao fazê-lo "viabilizou um projeto excludente, em que o objetivo das elites é manter a diferença com relação ao restante da população" (Manolo Garcia Florentino, apud Pompeu, p. 64).

\footnotetext{
${ }^{62}$ KOSHIBA, Luiz e PEREIRA, Denise F. Manzi. História do Brasil, 6 ed., São Paulo: Atual, 1993, p. 34.

${ }^{63}$ Op. Cit., 2000, p. 62-63.
} 
O valor do trabalho, decorrente desta formação cultural, é, até os dias atuais, legado à uma situação de completo desfavorecimento, como se ao outro, inferior em classe (e muitas vezes estigmatizado por conta da cor da pele), fosse dado o dever de trabalhar de maneira inesgotável, com a crescente retirada de direitos, de modo que costuma considerar a elite que "um trabalhador que até há pouco tempo era escravo, já tem muito se lhe é conferido algum direito. ${ }^{64,}$

O caráter agrário do país começa a se modificar com a introdução das primeiras indústrias, a partir do final do século XIX e início do século XX, introdução esta proveniente dos investimentos dos então colonos, adquiridos com o sucesso da exportação cafeeira, transformados em novas formas de acumulação de capital, ideias trazidas da já ocorrida revolução industrial europeia.

Em 1810, já havia fábricas instaladas, sendo do ramo têxtil (Rio de Janeiro) e siderúrgico (Minas Gerais e São Paulo). Em 1845, Irineu Evangelista de Souza, o Visconde de Mauá, instala em Ponta D’Areia (Niterói, Rio de Janeiro) fábrica de fundição e estabelecimento naval. Na Bahia, por volta de 1890, instala-se fábrica têxtil denominada "Cia. dos Fiais".

Foi, entretanto, Luís Tarquínio, denominado como o pioneiro dos patrões humanitários, que inseriu em sua fábrica de tecidos, em 1889, obras sociais destinadas à urbanização e higiene dos operários, como anota Catharino:

[A obra] desenvolvida no complexo da "Vila Operária" (inaugurada em 1902), com a "Escola Rui Barbosa", inclusive museu de história natural, com serviço de assistência médica completa (Adriano Gordilho à frente durante mais de 40 anos), e até com jornal para os operários ("O Trabalho") e revista ("Cidade do Bem"), deveria ser motivo de orgulho para todos os brasileiros. Apenas mais um fato significativo: o regulamento da "Vila" assegurava à operária gestante e parturiente salários integrais durante quinze dias antes e trinta dias após o parto ${ }^{65}$.

\footnotetext{
${ }^{64}$ MAIOR, Jorge Luiz Souto. Op. Cit., 2000, p. 64.

${ }^{65}$ CATHARINO, José Martins. Compêndio Universitário de Direito do Trabalho, vol. I, Ed. Jurídica e Universitária, São Paulo: 1972.
} 
O industriário Jorge Street, dono de uma fábrica de tecidos de juta, fez semelhante em São Paulo, onde, no distrito do Belém, criou vila operária com escola, creche, igreja, clube recreativo e esportivo, denominada por Maria Zélia, muito conhecida na cidade ${ }^{66}$.

São estas atitudes, entretanto, baseadas em uma concessão patronal, que iniciam a abertura de uma perspectiva de classe aos trabalhadores (diferente do Welfare State americano, mediado por políticas do Estado), e então lhes possibilita uma visão além da exploração de trabalho, iniciando a reivindicação de seus direitos.

Neste período do século XIX ao século XX, entretanto, cabe destacar que pouco se obteve em termos de legislação relativa ao trabalho, notadamente em razão do que se discutiu até então. Em 1830, observa-se lei que regulou o contrato de prestação de serviços dirigida a brasileiros e estrangeiros, o que ocorreu muito em razão da profusão da mão de obra imigrante que estaria por vir.

O crescimento na elaboração das leis de proteção ao trabalho, entretanto, não surgiu apenas com os governos que foram sendo instaurados com a República, mas especialmente como resultado de luta do operariado, mormente na insistência em greves, diferentemente do que se costuma afirmar.

O processo deu-se de maneira paulatina, gradual, cujo resultado se mostrou ínfimo diante do que se precisou perder de vidas operárias para a melhoria das condições de trabalho. A argumentação burguesa foi incisiva, baseada unicamente nos ideais iluministas de liberdade, pauta em que se acreditava serem os homens todos livres, e portanto, aptos para venderem sua força de trabalho.

Entretanto, o eminente mestre Evaristo de Moraes, já em 1905, assistia à opressão da classe sem se calar, redigindo em seus textos jornalísticos e em sua doutrina aquilo que a burguesia fingia não ver:

O homem é livre - argumentam; tem o direito de vender o seu trabalho pelo preço e nas condições que quiser. Mas, na vida industrial moderna, essa liberdade de trabalho só tem gerado a opressão e a miséria, a exploração do operariado e seu rebaixamento progressivo.

\footnotetext{
${ }^{66}$ MAIOR, Jorge Luiz Souto. Op. Cit., p. 65.
} 
Hoje, já ninguém contesta quanto influi a inexorável lei da concorrência na remuneração do trabalho operário - e isso basta para desfazer o encanto ilusório da "liberdade do trabalho."67

Antes mesmo da abolição já havia alguns textos esparsos, como a Lei de 1830, que regulava o contrato por escrito sobre prestação de serviços de brasileiros ou estrangeiros feitos dentro ou fora do Império (do qual se pode apontar fato curioso: em seu art. $7^{\circ}$, havia a proibição expressa de contratar com "africanos bárbaros", à exceção dos já existentes no Brasil); em 1837, regulando a locação de trabalho onde figurasse estrangeiro como locador, tendo sido ambas revogadas com o Governo Provisório de 1890.

O Código Comercial, de 1850, tratou de cuidar de algumas disposições acerca dos trabalhadores, em razão da expansão da atividade comercial, do que se pode destacar haver cuidado: dos altos-empregados (feitores, mestres, administradores ou diretores de fábricas); do acidente de trabalho; do aviso prévio; da indenização pela denúncia antecipada dos contratos a termo resolutivo; da justa causa; do trabalho marítimo, etc.

Da abolição da escravidão até o início da era Vargas (Revolução de 1930) os diplomas de maior relevância são: em 1891, a limitação do trabalho do menor, admitindo-se apenas os maiores de 12 anos no interior das fábricas dentro do Distrito Federal; 1903, lei sobre sindicalização dos profissionais da agricultura; em 1907, lei sobre sindicalização dos trabalhadores urbanos; em 1916, o Código Civil, com o capítulo sobre locação de serviços, regulamentando a prestação de serviços de trabalhadores; em 1919, temos uma lei sobre acidente do trabalho, seguida do Tratado de Versalhes; em 1923 é a Lei Elói Chaves, disciplinando a estabilidade no emprego conferida aos ferroviários que contassem 10 ou mais anos de serviço junto ao mesmo empregador, instituto, mais tarde, estendido a outras categorias; em 1925, há lei assegurando férias anuais de 15 dias, sem prejuízo da remuneração, a empregados e operários de estabelecimentos comerciais, industriais, bancários e jornalísticos. Em 1930 cria-se o Ministério do Trabalho ${ }^{68}$.

\footnotetext{
${ }^{67}$ MORAES FILHO, Evaristo de. Apontamentos de direito operário. 2 ed., Edição comemorativa do centenário do Autor, LTr, São Paulo: 1971, p. 9.

${ }^{68}$ BARROS, Alice Monteiro de. Curso de direito do trabalho. 6 ed., São Paulo: LTr, 2009, p. 69-70.
} 
É a Constituição de 1934, entretanto, que exerce um verdadeiro marco histórico no desenvolvimento legislativo do país, uma vez que foi a primeira a declarar direitos econômicos e sociais, de modo que a "ordem econômica deve ser organizada conforme os princípios da justiça e as necessidades da vida nacional, de modo a que possibilite a todos existência digna".

Seguiram tais ditames à maneira liberal-progressista, estabelecendo direitos anteriormente não previstos em um texto constitucional - igual salário, salário mínimo, duração do trabalho em geral, assistência e previdência, convenções coletivas, regulamentação estatutária "de todas as profissões", instituição da Justiça do Trabalho; etc.

Em 1937, com o golpe e a criação do Estado Novo, possibilitava ao presidente, instituído Ditador, o poder de legislar sobre, inclusive, o "direito operário", o que foi feito para que se garantisse a "situação autocrática" 69 ", ou ainda, segundo o Professor Souto Maior, como uma "fórmula da classe burguesa para impedir a emancipação da classe operária. [Uma vez que] Com o direito do trabalho a separação de classes se mantém $^{70,}$.

Ainda assim, as precárias condições de trabalho eram vigorantes no Brasil, razão pela qual as greves dos operários ainda ocorriam em massa, notadamente influenciados pelos movimentos sindicais inspirados pelos ideais anarquistas, socialistas e comunistas, bem como da implantação do Partido Comunista, em 1922.

Neste cenário, surge, então, a maior manifestação legislativa em matéria de direito do trabalho, a Consolidação das Leis do Trabalho, aprovada pelo Decreto-Lei n. 5452 , de $1^{\circ}$ de maio de 1943 , entrada em vigor em 10 de novembro do mesmo ano aniversário do Estado Novo, e publicada em 9 de agosto, que, em meio a reformas políticas e a revoltas sociais, surge como um elemento aplacador da fúria social e um ótimo instrumento de propaganda política, que incrementou o ideal de que os direitos trabalhistas haviam sido concedidos, ao invés de conquistados.

\footnotetext{
${ }^{69}$ CATHARINO, José Martins. Op. Cit., p. 29.

${ }^{70}$ MAIOR, Jorge Luiz Souto. Op. Cit., 2000, p. 69
} 
A CLT constitui-se de marco histórico eminente do direito do trabalho, uma vez que retira da regulamentação civil um assunto muito peculiar que é a prestação subordinada de trabalho por pessoa natural, outrora tida como mera locação de serviços pelo Código Civil de 1916, para, então, estruturá-la como a relação de emprego, constituída por um vínculo entre o prestador de serviços, agora denominado como empregado, ao seu tomador, o empregador, com características e proteções específicas, distintas da legislação civilista da época de influências iluministas.

O estatuto serve-se, em conjunto à Constituição da República e aos Tratados da Organização Internacional do Trabalho ratificados pelo Brasil, como limites mínimos à força aviltante do capital, com o fundamento principal da dignidade da pessoa humana e o valor social do trabalho.

Neste assunto em especial, são diversas as tentativas de reforma da CLT, a fim de se admitir a precarização da estrutura de emprego, como a regulamentação da terceirização (à exemplo dos Projetos de Lei 4.330/2004, do Deputado Federal Sandro Mabel; o PL n ${ }^{\circ}$ 6.832, do Deputado Paulo Delgado, dentre outros), a admissão dos trabalhadores como "pessoas jurídicas" (trabalhadores intelectuais, autônomos) e até mesmo, chancelada pela Corte Suprema do país, a admissibilidade de retirada completa de direitos do trabalhador terceirizado pelo poder público, com a completa isenção de responsabilidade de suas entidades em caso de inadimplemento de verbas trabalhistas por parte da empresa prestadora de serviços.

Trata-se da Ação Direta de Constitucionalidade $n^{\circ} 16$, proposta pelo Governador do Distrito Federal no ano de 2007, cujo julgamento pelo Supremo Tribunal Federal se deu em 25 de novembro de 2010, decidiu tratar-se de constitucional o art. 71 da Lei 8.666/93, admitindo à administração pública a contratação de empresa terceirizada, e, ainda, afastando em definitivo a responsabilidade do Poder Público em relação a qualquer débito trabalhista e fiscal das empresas contratadas, inobstante o art. 37 da Constituição da República ser claro e expresso ao admitir a prestação de serviços apenas por intermédio da realização de concurso público.

Vale ressaltar que apenas dois ministros pronunciaram-se contrários à admissão do referido preceito, do que se pode concluir que o julgado possui carga fortemente política. 
O que se objetiva ressaltar é que as novas formas de exploração do trabalho humano, provenientes dos modelos de flexibilização, em completo aviltamento a direitos arduamente conquistados, seja por sua flexibilização ou desregulamentação, constituem-se ofensa ao vínculo de emprego formalmente constituído pela CLT, de forma que o Poder Judiciário, órgão cujo dever precípuo é o defesa da ordem e da segurança jurídica, rechaça as normas em vigor, em um franco retrocesso social.

O retorno às antigas formas de exploração, sem qualquer proteção à dignidade do trabalhador, parece estar sendo renovado, na medida em que o neoliberalismo avança sobre as proteções de outrora.

\subsection{Flexibilização e globalização}

Com o advento do toyotismo, flexibilizar tornou-se um dos neologismos mais utilizados pelos estudiosos do mercado, sempre com a bandeira de que é necessário flexibilizar direitos, ou seja, moldá-los ao mundo atual, regulando-se a relação de trabalho de forma nova, adaptando-a ao mundo globalizado, para se garantir empregos.

E então, crescente é a categoria dos trabalhadores nos setores de serviços, bem como daqueles que submetem às novas formas de trabalho precarizadas, notadamente nas subcontratadas, uma vez que surgem a partir do modelo anterior, mas com a redução de direitos jamais vista, à exemplo do trabalhador "part time" (em tempo parcial), ou seja, que laboram em jornada reduzida, com vencimentos também reduzidos; com contratos com prazos determinados, em franca quebra ao princípio da continuidade da relação de emprego, submetendo os trabalhadores à prestação de serviços com pouca ou nenhuma garantia; os terceirizados e subcontratados, que tem sua relação de emprego, antes mantida com o efetivo beneficiário de seu trabalho, completamente cindida, respondendo agora para uma empresa menor, com menor solidez, a baixos salários e quase nenhuma condição digna de trabalho.

Ainda, conforme alertou Bihr, a parcela dos trabalhadores informais é como um exército, composta de trabalhadores com pouca ou nenhuma qualificação profissional para se manterem no emprego e tampouco competitivos no mercado, mas que se constituem pura e simplesmente como um excedente da fábrica enxuta. Acabam por ser despejados nas filas dos desempregados, vindo a se socorrer do trabalho informal, que 
não contribui com a geração de contribuição à Receita (prejudicando, portanto, todo o sistema previdenciário) e se submetendo a todos os riscos da atividade profissional.

Da mesma forma, ocorre o aumento da força de trabalho feminina, que atinge mais de $40 \%^{71}$ da força de trabalho em diversos países avançados, absorvida preferencialmente nas formas precarizadas, como "part time", sendo certo que sua remuneração é inferior ao trabalho masculino.

O teletrabalho, o trabalho em domicílio, possibilitados pelas tecnologias da informação e das telecomunicações obtém grande parcela de recrudescimento, aumentando o período em que o trabalhador permanece à disposição, prolongando sua jornada.

Em suma, pode-se afirmar que a ideia de flexibilização, em nossa realidade, tem sido utilizada com o pressuposto único de satisfação do interesse econômico, de modo que o capital, encontrando como aliada a política neoliberal, perquire por alterações legislativas que tem um fim específico, qual seja, a diminuição do custo do trabalho, objetivo completamente distinto de sua preocupação fundamental - a melhoria das condições de trabalho do trabalhador, preservando-lhe a dignidade e garantindo uma contraprestação justa pelo serviço.

E, neste sentido, convencionou-se pela assembleia constituinte de 1988, juntamente com os diplomas que se seguiram, que os direitos fundamentais dos trabalhadores são: salário mínimo; limitação da jornada (adicional de hora extra); adicional noturno; férias anuais (feriados); $13^{\circ}$ salário; regras de proteção ao salário; proteção contra alterações contratuais por ato exclusivo do empregador (art. 469 da CLT); descanso semanal remunerado; verbas indenizatórias para a dispensa injusta; aviso prévio; estabilidades provisórias no emprego, em casos excepcionais e socialmente justificáveis; FGTS; proteção do trabalho da criança, do adolescente e da mulher; normas de segurança e higiene do trabalho; direito de greve e seguro social contra contingências sociais.

Tais direitos são irrisórios, diante do que o capital aufere da mão de obra do trabalhador, uma vez que não mais se verifica, por exemplo, a estabilidade como regra

\footnotetext{
${ }^{71}$ ANTUNES, Ricardo, Op. Cit., 2009, p. 105.
} 
geral, ou garantias de aumento real dos salários de acordo com os índices da inflação. Retirar ou condicionar tais direitos significaria seu imediato aviltamento.

Os direitos trabalhistas no Brasil se constituem de garantias ainda muito inferiores aos objetivos da República e de preservação da dignidade humana do trabalhador. Diferentemente do que se alega, tais direitos em diversos países do mundo são muito melhor amparados, prevendo aos trabalhadores limites inferiores de jornada e ganhos maiores em razão de horas extras (ex. Austrália, com adicional de 150\% e limite semanal da jornada em 38 horas) ou a estabilidade no emprego como regra, devendo a dispensa ser sempre motivada, como na Espanha e na Nova Zelândia ${ }^{72}$.

Desta forma, descabida é qualquer afirmação no sentido de que o verdadeiro entrave para o crescimento econômico no Brasil é a excessivamente protetiva legislação trabalhista, porquanto parece que "conspira contra a ampliação do espaço de negociação",73 para o capitalismo.

Como se observou, a nova ordem mundial trazida pelos novos processos de produção, incutidos nos ideais individualistas do neoliberalismo, não pode, por um longo tempo se sustentar. O empobrecimento geral da sociedade é certo, e a passos largos já ocorre, de modo que não poderá servir de base para o capitalismo em um futuro não muito distante.

A perda do sentido social do trabalho e da consciência de classe dos trabalhadores, aliados às condições precárias de trabalho e a miserabilidade de seus salários é o verdadeiro estopim para que a bomba da desigualdade exploda. E então, será tarde demais para o capitalismo enxergar que flexibilizar não é a melhor opção para seu desenvolvimento.

\subsubsection{Paradoxo flexibilização e criação de novos empregos}

A palavra de ordem do mundo capitalista globalizado de hoje é flexibilizar. E flexibilizar refere-se à adaptação das normas de proteção existentes às exigências do

\footnotetext{
${ }^{72}$ Para uma visualização completa dos direitos trabalhistas assegurados em uma grande amostra de países, vide MAIOR, Jorge Luiz Souto, Op. Cit., 2000, p. 145-154.

${ }^{73}$ PASTORE, José. Flexibilização dos Mercados de Trabalho e Contratação Coletiva, São Paulo, LTr: 1995 , p. 15.
} 
capital, o qual requer maior maleabilidade dos trabalhadores e dos sistemas jurídicos de proteção para o fim de funcionar na rapidez que as relações comerciais se desenvolvem.

De acordo com o economista José Pastore ${ }^{74}$, figura de destaque do governo Fernando Henrique Cardoso (marcado eminentemente pelo neoliberalismo que resultou em uma grande crise do capital, notadamente em razão da ingerência da moeda internacional na economia), apresenta a flexibilização como alternativa única para o desemprego, uma vez que seus encargos sociais constituem-se de verdadeiro obstáculo para o desenvolvimento do país.

Ocorre, todavia, que há uma situação com a qual existe uma irrefutável concordância, conforme salientou Umberto Romagnoli, que afirma poder ser a flexibilização "considerada como uma droga: se acostumam com ela rapidamente, nunca têm o suficiente e querem doses cada vez maiores".

E isto é fato. Uma vez que o empresário observa quão reduzidos estão seus custos com mão de obra, notadamente pelo fato de poder produzir mais com menos contingente, de forma que tende a incrementar seus lucros, passa a tentar encontrar nichos na legislação (ou até mesmo os cria, indiferente ao conteúdo em vigência) que o permita fazer isso ainda mais intensamente.

Daí então, passa a atacar fortemente o vínculo de emprego, exigindo, muitas vezes, dos seus empregados que peçam demissão e se tornem pessoas jurídicas para continuar lhe prestando serviços, ou até mesmo que o faça na informalidade, conforme restou demonstrado alhures, em franco avanço à precarização.

O empregado passa de assalariado a microempresário, acrescentando ao seu nome o sufixo "ME", ou mais modernamente, o "LTDA"75, mas sem usufruir de qualquer das poucas vantagens que ser seu próprio patrão pode trazer. Continua tendo que respeitar horários (de entrada, mas talvez não de saída), ser subordinado, mas, em contrapartida, não tem mais as garantias de outrora - seu FGTS está paralisado, suas férias, quando e se as tiver, não serão remuneradas corretamente; seu $13^{\circ}$ salário, se pago, o será na modalidade oficiosa, sem passar por qualquer registro de contabilidade.

\footnotetext{
${ }^{74}$ PASTORE, José. Op. Cit., p. 157.

${ }^{75}$ Referência à já citada EIRELI, Lei no $12.441 / 2011$.
} 
As promessas de emprego provenientes da flexibilização se fixam apenas na precarização das condições de trabalho, e jamais cumprem seu objetivo.

O trabalho parcial, ou "part time", os contratos por prazo determinado, a terceirização, não constituem alternativa para o desemprego, uma vez que somente se constituem de instrumento para que o trabalhador tenha de trabalhar mais, em piores condições, muitas vezes em dois empregos, para que consiga garantir o sustento de sua família. A falta de fixação a uma única fonte de renda, por tempo superior ao que os contratos por prazo determinado permitem impossibilitam o trabalhador de consumir a prazo, ou planejar seus gastos, uma vez que está imerso na situação da efemeridade do trabalho.

Neste sentido, para alguns que consideram ser estas consequências meros reflexos da intercessão desmedida do Estado, a solução para tais problemas seria sua completa ausência, permitindo-se a regulação por meio da vontade das partes.

É exemplo o estudioso Milton Friedman ${ }^{76}$, que assim afirma:

Qualquer intervenção no livre jogo do mercado é coercitiva. A intervenção do Estado só se justifica para manter a lei e a ordem, julgar disputas sobre a interpretação da lei, reforçar os contratos, promover a competição, evitar o monopólio. O Estado não deveria intervir para fixar salário mínimo, pois iria distorcer o mercado; em programas de previdência, em razão de que iria provocar injustificada distribuição de renda e um incentivo para os filhos que não viessem a cuidar dos pais idosos. A fixação de salários pelos sindicatos é prejudicial ao trabalhador, em razão de excluir do mercado os que querem trabalhar sob remuneração menor. A melhor garantia para o empregado é a concordância entre empregadores para a garantia de seus serviços e a melhor garantia para o empregador é poder escolher entre vários empregados o que melhor o satisfaça. Deveria haver redução nas atividades do Estado. O Estado mínimo só pode ser conquistado se houver um Estado forte.

Desta forma, em verdade as relações de emprego, para que se autorregulassem, como as do mercado, deveriam ocorrer somente de acordo com a manifestação de

76 FRIEDMAN, Milton e Rose. Liberdade de escolha, 1988, apud MARTINS, Sérgio Pinto. Flexibilização das condições de trabalho. 3 ed., São Paulo, Atlas: 2004, p. 19. 
vontade das partes, notadamente se os empregados desejam, por uma circunstância ou outra, auferir menor renda (situação que é impossível de ser vislumbrada senão por uma coação irresistível, ainda que implícita, do tomador de serviços), ou então, trabalhar mais sem qualquer garantia.

Ocorre, todavia, que a flexibilização proveniente da globalização, que nada mais significa que o afastamento gradual do Estado na regulamentação das relações de trabalho, seja por revogar disposições com outras mais flexíveis, ou pela omissão no afastamento de práticas contrárias ao ordenamento (como decisões judiciais permissivas, políticas econômicas de favorecimento ao capital estrangeiro, etc), só trouxe problemas sociais que se multiplicam e até hoje não encontram solução no modelo de exploração atual.

Interessante destacar, novamente, que para ilustrar o quadro caótico ocasionado pelo novo modelo de produção, tem-se por conclusão necessária que o achatamento das garantias sociais não é o diferencial que trará melhores condições de empregabilidade, uma vez que as taxas de lucro têm sido cada vez maiores, mas igualmente tem sido a taxa de desemprego e, por consequência, como acima aludido, os problemas sociais, como ilustram Martin e Schumann:

\footnotetext{
Em nenhum outro lugar a decadência social se mostra tão claramente quanto no país que deu origem à contra-revolução capitalista: nos EUA, a criminalidade assumiu proporções epidêmicas. No Estado da Califórnia, que seria considerado individualmente, a sétima potência econômica do mundo, as despesas com presídios ultrapassam o total do orçamento para cultura. ${ }^{77}$
}

Trata-se, portanto, de uma alegação falaciosa; a flexibilização das condições de trabalho, aliado a um modelo de governo neoliberal, permissivo, que valoriza o capital e que se omite diante da infringência das normas sociais, traz problemas em ordem progressiva à sociedade como um todo, uma vez que não se restringe à esfera de uma ou de algumas fábricas, mas da ordem capitalista de produção - e da sociedade que se deteriora, portanto.

\footnotetext{
${ }^{77}$ SCHUMANN e MARTIN, p. 130, apud MAIOR, Jorge Luiz Souto, Op. Cit., 2000, p. 130.
} 
Como resultado, contrariamente aos índices de empregabilidade que vem prometendo, a precarização das condições de trabalho com o enxugamento das indústrias e com a introdução de legislações que apoiam o modelo, só trouxe o desemprego estrutural e outras consequências, como considera o Prof. Ricardo Antunes:

O mais brutal resultado dessas transformações é a expansão, sem precedentes na era moderna, do desemprego estrutural, que atinge o mundo em escala global. Pode-se dizer, de maneira sintética, que há uma processualidade contraditória que, de um lado, reduz o operariado industrial e fabril; de outro, aumenta o subproletariado, o trabalho precário e o assalariamento no setor de serviços. Incorpora o trabalho feminino e exclui os mais jovens e os mais velhos. Há, portanto, um processo de maior heterogeneização, fragmentação e complexificação da classe trabalhadora ${ }^{78}$.

Observa-se, neste sentido, que as indústrias sofreram uma grande perda de mão de obra, laborando de forma a adaptar-se às novas modalidades de produção, introduzidas pela robótica, pelo avanço das telecomunicações e de toda ordem de tecnologia fabril e de automação industrial.

Se, sob a mundialização do capital ocorre o crescimento da classe dos trabalhadores assalariados, com a particularidade da redução e metamorfose da classe operária tradicional, do crescimento dos assalariados dos "serviços" e da proliferação do trabalho assalariado "precário", ou do subproletariado, também instaura-se, como um componente contraditório do desenvolvimento capitalista, o crescimento do desemprego estrutural, com a constituição de um novo patamar de exclusão social nos principais países capitalistas.

Nestes, mais especificamente da Europa Ocidental, os efetivos de trabalhadores ocupados na indústria representavam cerca de $40 \%$ da população ativa no começo dos anos 40. No ano 2000, sua proporção se situava próxima dos $30 \%{ }^{79}$.

No ano de 2010, considerando-se o universo da Alemanha, França, Itália e Espanha, o índice caiu para $16,7 \%$ da população empregada na indústria ${ }^{80}$.

\footnotetext{
${ }^{78}$ ANTUNES, Ricardo, Op. Cit., 2000, p. 49-50.

${ }^{79}$ Idem, p. 51.
} 
Da mesma forma, segundo a OIT, há perto de um bilhão de desempregados no mundo, sendo 40 milhões encontrados nos países avançados ${ }^{81}$. A lógica, portanto, não é outra senão do descarte de mão de obra, do que se pode facilmente depreender tratar-se o reestruturação produtiva e a flexibilização das normas protetivas de uma lógica perversa, que vive da precarização.

$\mathrm{Na}$ verdade, o imperativo do capitalismo mundial é, cada vez mais, introduzir novas tecnologias microeletrônicas e novos padrões organizacionais vinculados à lógica do toyotistmo (o "lean production"), não apenas na indústria, mas no setor de serviços, que tendem a não possuir mais a capacidade de absorver a parcela de trabalhadores assalariados que estão à procura de empregos.

\section{Como destaca o Prof. Giovanni Alves ${ }^{82}$,}

o predomínio da financeirização da riqueza, uma das determinações intrínsecas à mundialização do capital, impulsiona o processo de valorização na perspectiva da redução do trabalho vivo como estratégia de rentabilidade acionária.

As políticas neoliberias tendem a promover a desigualdade social com virtude de um novo patamar de acumulação e alocação de riqueza, o que demonstra ser o desemprego um problema político, e não apenas um mero problema macroeconômico, decorrente das condições do mercado e da excessiva interferência do Estado na regulamentação das relações privadas.

E, como adverte a pesquisadora Liana Carleial $^{83}$,

\footnotetext{
Nos países subdesenvolvidos, porém, os efeitos da reestruturação industrial podem ser ainda mais danosos, pois a retração dos postos de trabalho em grandes empresas, com política salarial e de benefícios bem estruturadas, pode estar sendo acompanhada da criação de postos de trabalho inseguros e com remunerações ainda mais baixas, diante dos excedentes populacionais disponíveis. Ademais, o arsenal da política econômica é, em geral, compromissado com a estabilidade monetária e as contas externas...
}

\footnotetext{
${ }^{80}$ OIT - Índice de Emprego total - Quadro 9, de www.ilo.org.br, acesso em 08 de junho de 2012.

${ }^{81}$ VIANA, Marcio Tulio. Op. Cit., p. 163
} 
Interessante destacar que, neste mesmo sentido, o economista Joseph Stiglitz, pesquisando o desenvolvimento mundial e a pobreza, concluiu que, como reflexo das novas condições capitalistas da globalização, o número atual de pessoas vivendo na pobreza atualmente aumentou em quase 100 milhões ${ }^{84}$. Isto ocorreu ao mesmo tempo em que a renda mundial aumentou em média $2,5 \%$ ao ano.

Por dedução, pode-se facilmente depreender que o desemprego aumentou, a precarização do trabalho levou à informalidade e, como consequência, a pobreza é o maior desafio da atualidade. Em contrapartida, os lucros aumentaram, e sua concentração, em igual proporção, levou ao enriquecimento de poucos.

Não há como se concluir, portanto, que as novas técnicas de produção geram mais postos de emprego. Em verdade, encontrou-se um nascedouro de oportunidades para o capital, acompanhadas de um amplo quadro de desemprego estrutural - aquele em que os postos de trabalho são extirpados da indústria, de cariz, portanto, irreversível.

Os benefícios para o capital, sem dúvida, são diversos, de forma que, sem qualquer resistência de classe ou do poder público encontram meios para se disseminar e ampliar sua margem de lucro. Deixam para trás, contudo, o rastro de miséria social e a desilusão do ser humano, acreditando que trabalhar não mais é o centro da sua vida, de forma que não mais adquirirá seu sustento ou poderá realizar seus sonhos - e, por conseguinte, transformar o organismo social em instrumento de desenvolvimento para a humanidade, deixando de atingir os objetivos expostos na Constituição da República.

\subsubsection{Flexibilização versus desregulamentação}

Ao que parece, o crescimento e o desenvolvimento da economia é contraditório às normas de proteção ao trabalhador, de forma que, em um primeiro momento, para ser possível a competitividade de uma nação na economia globalizada, segundo a maioria dos economistas e defensores da política neoliberal, o ideal seria a total regulamentação

\footnotetext{
${ }^{82}$ ALVES, Giovanni. Op. Cit., p. 76.

${ }^{83}$ CARLEIAL, Liana. Op. Cit. p. 154-155.

${ }^{84}$ STIGLITZ, Joseph E. Globalization and Its Discontants. New York/London, 2003, p. 6, apud PIOVESAN, Flávia. Direito ao trabalho e a proteção dos direitos sociais nos planos internacional e constitucional, In PIOVESAN, Flávia e CARVALHO, Luciana Paula Vaz de (orgs.). Direitos Humanos e Direito do Trabalho, São Paulo: Atlas, 2010, p. 13.
} 
das relações de trabalho pelas leis de mercado, em uma franca desregulamentação legal já existente.

Neste sentido, é necessário empreender a distinção da flexibilização das normas e da desregulamentação do direito do trabalho, muito embora ambas, ao que restou claro, sejam prejudiciais aos trabalhadores e à sociedade como um todo, se perpetradas no sentido reducionista de direitos.

Em sentido contrário, contudo, referida distinção pode, inclusive, auxiliar o legislador para o fim de salientar a necessidade de manutenção de normas de proteção, e, por conseguinte, fazer flexibilizar as leis de mercado, para o fim de se estabelecer uma ordem baseada na justiça social.

Esta foi, ademais, a preocupação do Diretor Geral da Organização Internacional do Trabalho (OIT), Sr. Michel Hansenne, cujo mandato foi de 1989 a 1999, ao emitir relatório sobre as condições de trabalho na era da globalização, no ano de 1996, período em que o trânsito comercial transnacional era recente e crescia vultosamente:

\begin{abstract}
A cooperação internacional deve encaminhar-se para humanizar a globalização, conciliando as necessidades em matéria de justiça social com os imperativos da competição econômica.

Insto aos Estados-Membros da OIT a que abandonem a prática de normas trabalhistas e condições sociais artificialmente desfavoráveis, que lhes permitem obter vantagens desleais, e se esforcem por encontrar mecanismos que permitam distribuir com equidade os benefícios da liberalização do comércio ${ }^{85}$.
\end{abstract}

Certo é, neste sentido, que o objetivo estabelecido pela OIT é de preservação da proteção ao trabalhador diante das mutações bruscas que a relação capital-trabalho vem sofrendo, de forma a proteger a sociedade de um verdadeiro "dumping" social mundial - no qual os países dominantes, organizando-se no sentido de excluir ou reduzir minimamente a proteção aos trabalhadores, consigam tornar-se competitivos desta forma, uma vez que possibilitam a entrada de seus produtos no mercado com preços inferiores, excluindo, portanto, naturalmente os demais.

\footnotetext{
${ }^{85}$ In SÜSSEKIND, Arnaldo. Direito constitucional do trabalho, 2 ed., Rio de Janeiro, Renovar:2001, p. 46.
} 
Estabelece-se, então, a concorrência desleal, o prejuízo aos consumidores em razão da detenção de parcela significativa do mercado consumidor (monopólio) e, ao mesmo tempo, causando impactos irreversíveis na arrecadação previdenciária e nos trabalhadores, agora em péssimas condições de trabalho ou em desemprego.

Desta forma, fator determinante é o estabelecimento de normas que garantam a dignidade do trabalhador e que, por conseguinte, possibilitem uma justa concorrência entre as nações.

$\mathrm{Na}$ retórica neoliberal, entretanto, a lei é rígida em excesso, tem raízes corporativistas, se fez em uma época eminentemente agrária do país, e, portanto, é completamente descabida às relações de hoje, mostrando-se extremamente paternalista, enquanto as relações exigem rapidez e disseminam a volatilidade. E, segundo coloca magistralmente o Prof. Viana, o que importa, falaciosamente, para os defensores desta lógica não é tanto "o Direito do Trabalho, mas o Direito ao Trabalho" "86, uma vez que o direito é um custo, do qual as empresas modernas tem de se livrar, em nome de sua própria existência...

Flexibilizar é, como se vem frisando, adaptar as regras do direito do trabalho à nova realidade, enquanto desregulamentar é deixar o trabalhador desguarnecido de qualquer proteção institucional.

Como pondera o Prof. Arnaldo Süssekind ${ }^{87}$,

Na flexibilização sobrevive a legislação de proteção ao trabalho com algumas normas gerais irrenunciáveis e outras que admitem as adaptações precitadas [já verificadas a teor do que dispõem os incisos VI, XIII e XIV, da Constituição da República]; na desregulamentação, o Estado não intervém nas relações de trabalho, para que a autonomia provada, coletiva ou individual, disponha, sem limitações legais, sobre as condições de trabalho.

E continua, advertindo:

\footnotetext{
${ }^{86}$ VIANA, Marcio Túlio, Op. Cit., p. 169.

87 SÜSSEKIND, Arnaldo. A globalização da economia e o direito do trabalho. In: Revista LTr, publicação mensal, Ano 61, nº 01, Jan/1997, p. 40-44.
} 
Do contrário, seria admitir a possibilidade de retorno à fase histórica em que as péssimas condições de trabalho justificaram a ampla e diversificada reação que fundamentou o advento da legislação socialtrabalhista.

Distintamente do que se cumpre dizer, o ordenamento trabalhista brasileiro, em absoluto, não se trata de rígido ou inflexível. A própria Constituição da República admite a possibilidade de flexibilização de algumas proteções: redutibilidade salarial, compensação de horários na semana e trabalho em turnos de revezamento (art. $7^{\circ}, \mathrm{VI}$, XIII e XIV), mas sob tutela sindical. Para este último, ainda, recentemente o Tribunal Superior do Trabalho admitiu, contrariamente a todas as disposições de saúde do trabalhador (e portanto, completamente inadmissível na lógica de proteção), a jornada de 8 horas em turnos de revezamento... Como denominar o ordenamento por inflexível, se até mesmo o judiciário trabalhista chancela tais reformas, por meio de jurisprudência consolidada?

Os exemplos, entretanto, não se esgotam na jurisprudência, uma vez que houve reformas na legislação no sentido de amparar a flexibilização das normas de proteção ao trabalho, além dos incisos do artigo $7^{\circ}$ acima delineados, tais como a ampla liberdade patronal para despedir os empregados sujeitos ao regime de FGTS (Lei 5.107/66, agora substituída pela Lei 8.036/90, muito embora haja uma forte corrente doutrinária no sentido de acreditar estar em vigor a Convenção n ${ }^{\circ} 158$ da OIT, que impedia a dispensa imotivada); a modalidade de trabalho em tempo parcial, conforme possibilita o art. 58A, da CLT; a possibilidade de suspensão do contrato de trabalho, de acordo com o art. 476-A, da CLT.

Constituem igualmente modalidade de flexibilização a ampliação do rol de contratos determinados, como se infere da Lei n. 9.601, de 1998, contendo redução de encargos, a terceirização disciplinada pela Súmula n. 331 do TST, a contratação de trabalhador temporário, na forma da Lei n. 6.019, de 1974, as formas de subcontratação variadas, o trabalho em domicílio, disciplinado pelo art. $6^{\circ}$ da CLT; o trabalho por meio de cooperativas, regulamentado pela Lei $\mathrm{n}^{\circ}$ 5.764, de 1971; o contrato de estágio, hoje regulamentado pela Lei $\mathrm{n}^{\circ}$ 11.788, de 2008; os trabalhadores intelectuais (ou a "pejotização") decorrente de uma interpretação extensiva do art. 129 da Lei $11.196 / 2005$, dentre diversas outras práticas. 
A desregulamentação, distintamente, conceitua-se pelo afastamento do Estado, ou seja, a retirada das proteções institucionais do trabalhador por autonomia da iniciativa privada, substituindo-se uma norma legal por outra autônoma. Por premissa inicial, básica de acordo com a perspectiva protecionista do trabalhador, qualquer tentativa de desregulamentação é nula de pleno direito, uma vez que vai de encontro com o quanto determinado pelo caput do artigo $7^{\circ}$ da Constituição da República:

Art. $7^{\circ}$ - São direitos dos trabalhadores urbanos e rurais, além de outros que visem à melhoria de sua condição social (...)

São tais direitos constituídos, portanto, de um núcleo mínimo de proteção, uma vez que o referido artigo admite outros direitos, com o objetivo de, progressivamente, melhorar sua condição social. Está aí o nascedouro do princípio da proibição ao retrocesso social às condições de trabalho, que será melhor discutido no capítulo 5 do presente trabalho.

Citando Javillier ${ }^{88}$, o Professor Arnaldo Süssekind resume a diferença ora estabelecida, no sentido de que:

A desregulamentação não é uma solução. E não se deve confundi-la com a flexibilização, porque nesta um núcleo de normas de ordem pública deve permanecer intangível.

Este núcleo intangível está descrito nos direitos sociais, dos quais os direitos trabalhistas são espécies na Constituição de 1988, sendo que se encontram no Título II desta, denominado como "Direitos e Garantias Fundamentais".

Cabe destacar que esta foi a primeira carta constitucional brasileira que encabeçou os direitos sociais como integrantes do elenco dos direitos fundamentais, inclusive com aplicabilidade imediata, além de ter sido o marco jurídico da transição democrática e da institucionalização dos direitos humanos. E, por assim dizer, constituem também os direitos trabalhistas, espécies dos direitos sociais, o arcabouço dos direitos humanos.

\footnotetext{
88 JAVILLIER, Jean-Claude. "Synthesis", no 23/96, SP, Rev. Do TRT da $2^{\text {a }}$ Região, p. 14-16, apud SÜSSEKIND, Arnaldo. Op. Cit., 2001, p. 52.
} 
Nada obstante, às normas internacionais ratificadas pelo ordenamento também se confere igual tratamento. O Ex-Ministro do Supremo Tribunal Federal, Sepúlveda Pertence, cujo mandato foi exercido de 1989 a 2007, neste sentido, afirmou, sabiamente, que "os direitos sociais dos trabalhadores, enunciados no art. $7^{\circ}$ da Constituição, se compreendem entre os direitos e garantias constitucionais incluídas no âmbito normativo do art. $5^{\circ}, \S 2^{\circ}$, de modo a reconhecer alçada constitucional às convenções internacionais anteriormente codificadas no Brasil" ${ }^{\prime 89}$.

Admite-se, portanto, que os tratados internacionais ratificados pelo Brasil que venham a dispor sobre direitos humanos, desde que não contrariados por preceito da Constituição, adquirem status desta Norma Maior, ou seja, também inserem-se no ordenamento como garantias fundamentais, o que reitera, portanto, a norma aberta exposta no referido artigo art. $5^{\circ}, \S 2^{\circ}$, podendo facilmente arriscar sem receio de que tal atributo é conferido independentemente da votação especial exigida no $\S 3^{\circ}$ do mesmo artigo. A classificação como direito fundamental é suficiente para que passe a integrar o conceito de cláusula pétrea ${ }^{90}$, sendo indiferente sua recepção como Emenda Constitucional; por excelência, é uma norma constitucional, posição esta já consolidada na doutrina.

Ora, como fundamental, a etimologia explica que se trata daquilo que não se pode dispor, tem caráter indispensável, porquanto intrínseco ao sistema e, portanto, à sociedade. Neste sentido, impossível conceber o país sem os direitos trabalhistas expostos, no sentido de se atingir, sempre, os objetivos da República, estipulados no art. $3^{\circ}$, como a promoção da justiça social, a erradicação da pobreza e a redução das desigualdades sociais e regionais.

Impossível olvidar, outrossim, que o direito do trabalho, conforme exposto no art. $7^{\circ}$ da Carta Magna jamais poderá ser objeto de emenda constitucional ou lei (nisso entenda-se a normatividade heterônoma e autônoma do direito do trabalho) tendente a aboli-lo, ou seja, desregulamentá-lo, uma vez que o artigo 60 do texto constitucional

\footnotetext{
${ }^{89}$ SÜSSEKIND, Arnaldo, Op. Cit., 2004, p. 87.

90 A Constituição da República de 1988 é a primeira Constituição Brasileira a incluir os direitos internacionais no elenco dos direitos constitucionalmente garantidos, nos termos do artigo $5^{\circ}$, $\S \S 2^{\circ}$ e $3^{\circ}$, da Constituição Federal, cf. PIOVESAN, Flávia. Op. Cit., p. 27.
} 
expressamente determina ser proibida proposta de emenda neste sentido, uma vez que se tratam de garantias individuais - são as chamadas cláusulas pétreas.

Neste sentido, imprescindível é a lição do Prof. Paulo Bonavides ${ }^{91}$ :

Tanto a lei ordinária como a emenda à Constituição que afetarem, abolirem ou suprimirem a essência protetora dos direitos sociais, jacente na índole, espírito e natureza de nosso ordenamento maior, padecem irremissivelmente da eiva da inconstitucionalidade, e como inconstitucionais devem ser declaradas por juízes e tribunais, que só assim farão, qual lhes incumbe, a guarda bem-sucedida e eficaz da Constituição.

E, contra esta disposição, somente a revolução poderá combater, uma vez que se trata do poder constituinte originário instituído. A revisão, ou o poder constituinte reformador, somente poderá ocorrer nos limites estabelecidos pela própria Constituição, de modo que haverá sempre o núcleo fundamental de normas inatingíveis por este poder, como são os direitos do trabalhador ${ }^{92}$.

A flexibilização, nesta ordem, é admitida pela Constituição nas hipóteses infirmadas em seu artigo $7^{\circ}$. Entretanto, certo é que se estabelece um conflito normativo, uma vez que, embora os incisos VI, XIII e XIV autorizem expressamente tais hipóteses é necessário aplicá-los em conformidade com o princípio da proibição ao retrocesso social, de modo que a norma não se torne um elemento de autorização para a consolidação de flagelos sociais, tendo-se em vista a natureza de sua regulamentação e o que visa flexibilizar.

Neste sentido, é possível encontrar entendimento jurisprudencial seguindo-se contra a flexibilização adotada pela Constituição da República, inobstante entendimento consolidado do TST (Súmula 423) de maneira especial no que tange à possibilidade de majorar o turno ininterrupto de revezamento, mediante negociação coletiva, para oito horas, sem o devido pagamento do adicional extraordinário, dado que ofende diretamente normas que visam garantir a higidez física e mental do trabalhador.

\footnotetext{
${ }^{91}$ BONAVIDES, Paulo. Op. Cit., p. 657.

92 SÜSSEKIND, Arnaldo, Op. Cit., 2004, p. 85-86.
} 
Não se pode, neste sentido, admitir o direito do trabalho sem a forte intervenção estatal (ainda que haja críticas diversas a respeito do Estado), porquanto é a instituição responsável pela manutenção e garantia de direitos, ainda que de forma repressiva pelo judiciário, dependente, muitas vezes, do ativismo judicial. Conforme demonstrado, a flexibilização de direitos em nada trouxe ao trabalhador ou ao país qualquer progresso social, sendo responsável pelo recrudescimento das desigualdades sociais já vistas.

Conforme salienta o Prof. Souto Maior, a intervenção estatal como forma de garantir direitos não se trata de um autoritarismo, "mas do reconhecimento de que as regras do mercado livre já nos levaram e não se inibirão de nos levar, novamente, aos horrores sociais do período pós-revolução industrial e pós-guerras. ${ }^{93}$,

Ainda assim, afora os limites materiais impostos, o Prof. Souto Maior continua sua lição, dizendo haver ainda outros limites impeditivos da flexibilização e da desregulamentação:

\begin{abstract}
Ataca-se o direito do trabalho porque seria ele o responsável pelo encarecimento da mão de obra, inviabilizando atividades empresarias. Dois aspectos devem ser levantados a respeito dessa questão: um de ordem moral, outro de natureza econômica. Moralmente, a alegação é hedionda, já que, levada a cabo, o seu fundamento é o de que se ainda houvesse a escravidão o sucesso dos investimentos empresariais estaria garantido. Desmerece-se, assim, a pessoa humana do trabalhador e a importância que seu trabalho possui para a atividade empresarial. Além disso, é falaciosa, tendo em vista a realidade histórica em que se podem verificar vários casos em que, apesar do regime de escravidão, as atividades empresarias - indústrias e na agricultura, principalmente - não obtiveram êxito, levando seu empreendedor à bancarrota. Do ponto de vista econômico, a argumentação, mais uma vez é falsa, já que o custo da mão de obra na realidade brasileira - representa muito pouco, em relação ao investimento total da empresa ${ }^{94}$.
\end{abstract}

A chave para o sucesso dos empreendimentos brasileiros, seja no mercado interno como no exterior, na competitiva corrida da globalização não reside nos parcos avanços e retrocessos da legislação social expressa no Brasil, do que se pode concluir

\footnotetext{
${ }^{93}$ MAIOR, Jorge Luiz Souto, Op. Cit., 2000, p. 279.
} 
ser mero argumento retórico da faceta neoliberal da política brasileira, que, movida pela força do capital, conseguem munir-se do monopólio ideológico da sociedade a seu favor. Por conseguinte, tais ideais fragmentam ainda mais a classe dos trabalhadores, já que são vistos como meros instrumentos de produção, descartáveis, maleáveis e moldáveis de acordo com as frias necessidades da economia.

Conforme será demonstrado, entretanto, o Brasil pós-ditadura foi construído sobre pilares de uma Constituição democrática, embasada em um constitucionalismo social, estimando o valor do trabalho mais que a sua exploração e, neste sentido, sempre o progresso social, por meio do ordenamento, em um franco avanço à justiça social.

E, como ponderou Kant ${ }^{95}$, as pessoas, e em geral qualquer ser racional, devem existir como um fim em si mesmo e jamais como um meio, a ser arbitrariamente usado para este ou aquele propósito. Logo, impossível empreender institucionalmente que sejam os trabalhadores meros meios para o acúmulo do capital, perdendo seu conceito de valor-fonte do direito para se tornar um ser apenas cumpridor de deveres, estes estabelecidos pelo direito, o direito do capital.

Indispensável, portanto, avaliar se as formas de exploração do trabalho hodiernas, especialmente a subcontratação, são coerentes dentro do contexto do ordenamento jurídico em vigor ou se se constitui de forma de precarização ainda mais intensa do trabalho, e, por assim ser, deva ser reprimida com a força da lei e do primado da justiça social.

\subsection{Subcontratação: conceito e delimitação}

A partir das observações histórico-sociológicas acima delineadas, é possível estabelecer o conceito e a delimitação do objeto do presente trabalho, de forma a pinçálo do universo das relações empresariais decorrentes da reestruturação produtiva.

Essa delimitação se faz imprescindível, uma vez que o universo da subcontratação deve ser compreendido, de agora em diante, com a semântica técnica que seus termos trazem, como todo e qualquer processo de transferência da produção para um terceiro, sendo este o objeto de estudo do presente trabalho.

\footnotetext{
${ }^{94}$ Idem, p. 155.
} 
A subcontratação pode, sem problemas de incorreções técnicas, ser tratada como terceirização, mas esta última deve ser entendida como gênero dos processos de externalização que a indústria brasileira passou a sofrer com o implemento das técnicas toyotistas de produção. Dessa forma, é possível afirmar que o processo de subcontratação produtiva é um método de terceirização, notadamente porque esta também designa a externalização dos serviços outrora componentes do complexo empresarial fordista, mas que não será abordado no presente tema.

Por subcontratação assim entende o Professor livre-docente e pesquisador da Universidade Estadual de Campinas, Éolo Marques Pagnani ${ }^{96}$ :

Subcontratação é um processo de relações jurídico-econômicas estabelecidas entre pequenas, médias e grandes empresas industriais, que normalmente é materializado mediante um acordo contratual entre uma empresa primária (contratante) e uma empresa secundária (subcontratada) para: 1) fornecimento, pelo subcontratado, por solicitação da empresa contratante, de peças, componentes, subconjuntos ou conjuntos, que serão incorporados ao produto da empresa primária, obrigando, por isso mesmo, as duas empresas a se envolverem em atividades de fabricação. 2) a elaboração (manufaturação) para a empresa contratante, fornecendo, ou não, esta última, as matérias-primas para a subcontratada. Pode também ser por operações de acabamento de peças, componentes ou produtos, que a empresa contratante fornece e recebe de volta.

Nesse aspecto, a subcontratação pressupõe, então, uma relação contratual que pode estabelecer-se formalmente ou informalmente pela mera entrega da planilha de pedidos ou simplesmente por solicitação verbal.

Interessante, contudo, observar que a subcontratação justamente em razão de sua análise sob a perspectiva jurídica, deve ser abordada de acordo com o impacto que causa ao mundo do trabalho, notadamente quando constituída a fim de incrementar sua precarização.

\footnotetext{
${ }^{95}$ Apud PIOVESAN, Flávia. Op. Cit., 2010, p. 6.
} 
E, nesse viés, ressalta a pesquisadora Liana Carleial $^{97}$ :

É importante reter, porém, que a crescente presença da subcontratação pode ser indicadora de um número cada vez maior de trabalhadores sem contrato de trabalho, porém subordinados organizacionalmente a uma determinada empresa. Em muitos casos, os contratos que se estabelecem entre as empresas são de natureza comercial, ficando a pequena empresa responsável pela contratação de trabalhadores ou ainda pela utilização de trabalhadores autônomos.

Observa-se, a partir da perspectiva ora apresentada, a completa fluidez dos processos de trabalho, do que se conclui pela alteração da forma de constituição das indústrias - aquela que concentrava toda a produção e serviços em benefício de seu produto final, funcionando como uma estrutura verticalizada, fora completamente planificada, horizontalizada, especializando-se por completo em seu produto final, ou muitas vezes, na exploração daquelas empresas que produzem seu produto final, retirando qualquer espaço outrora destinado a funções diversas para as submeterem à subcontratação de novas empresas, em cujas atividades supostamente tenham se especializado.

Como se verificou, a subcontratação ora estudada apresenta-se pela existência dos contratos de facção, de natureza civil e comercial, independentemente do nome formal que se lhe atribui, e ainda pela relação das redes de empresas.

Ao contrato de facção pode-se atribuir o conceito de que se trata de um "repasse a um terceiro da realização de parte (facção) das atividades necessárias à obtenção de um produto final (...). ${ }^{98, "}$ Tal contrato mescla conceitos da terceirização, representada no ordenamento jurídico brasileiro pela Súmula 331, do TST, com a empreitada e a subempreitada, regulamentada pelo art. 455, da CLT, contratos de natureza civil que, como se verá, não impedem o estabelecimento de uma relação trabalhista de responsabilidade.

\footnotetext{
${ }^{96}$ PAGNANI, Éolo Marques. A subcontratação na pequena e média empresa industrial. Campinas. UNICAMP. Tese de Doutoramento, 1976, p. 56-57.

${ }^{97}$ CARLEIAL, Liana. Op. Cit., p. 39.

${ }^{98}$ KROST, Oscar. Contrato de facção: fundamentos da responsabilidade da contratante por créditos trabalhistas dos empregados da contratada. In: Justiça do Trabalho, Ano $24-\mathrm{n}^{\mathrm{o}} 287$ - Novembro de 2007. HS Editora, pp. 28-35, p. 35.
} 
Por sua vez, o Prof. Irany Ferrari nos fornece elementos da referida modalidade contratual, afirmando que, em um só contrato, a um só tempo, verifica-se a prestação de serviços e o fornecimento de bens.

Nesse sentido, essa modalidade contratual apresenta tais características ${ }^{99}$ :

a) Entrega de peças em 'estado bruto' pela empresa contratante;

b) A realização dos serviços nas instalações da empresa contratante;

c) A autonomia da empresa contratada;

d) A entrega, ao final, de produtos acabados pelo contratante;

e) A inexistência de exclusividade na prestação de serviços pela empresa contratada, quem em regra, presta serviços a mais de uma empresa.

Como se verificou alhures, todavia, não se pode afirmar de forma generalizada que o contrato de facção seguirá sempre, a rigor, a manifestação dos elementos acima delineados, podendo se verificar a existência de exclusividade no fornecimento dos produtos acabados e, ainda, a própria realização dos serviços em locais diversos de onde se encontra a subcontratante, característica essa da descentralização produtiva.

Como bem coloca o Prof. Souto Maior, tal medida resultou da necessidade do capital em tornar nebulosa a identificação da relação de emprego alastrando a linha de produção para além dos limites físicos da fábrica.

E, nesse contexto, o processo produtivo acabou por ser "pulverizado em diversas unidades, fornecendo a aparência de que cada uma das unidades seja a realização de uma atividade empresarial específica. ${ }^{100,}$

Como visto, a empresa subcontratante passa a explorar a atividade de outras empresas, funcionando tal qual um centro de controle, muitas vezes estando localizada em outra região do planeta.

\footnotetext{
${ }^{99}$ FERRARI, Irany. Terceirização - contrato de facção - responsabilidade subsidiária. São Paulo - 2004 - Ano 40 - LTr Sup. Trab. 110/04 p. 486.

${ }^{100}$ MAIOR, Jorge Luiz Souto. Curso de direito do trabalho - A Relação de Emprego, Vol. II, São Paulo, LTr: 2008, p. 137.
} 
Necessário é, neste contexto, suscitar o fato de que a subcontratação é muitas vezes utilizada como subterfúgio para intermediação de mão de obra, de modo que esta não passa de um instrumento pelo qual a empresa principal se utiliza para o fim de evadir-se das leis fiscais, trabalhistas e de outra natureza, com um artificial deslocamento de sua massa produtiva para outra empresa. Neste caso, não há dúvidas de que se está diante de uma situação eminentemente fraudulenta, e que também deve ser reprimida pelo direito do trabalho.

Dessa forma, é a partir dessa perspectiva que se envidará a análise jurídica que o Brasil e outros países realizam acerca da subcontratação.

\subsubsection{Precarização das condições de trabalho e o dano social}

\subsubsection{A precarização}

Observa-se do desenvolvimento deste trabalho que a todo tempo é feita referência à precarização das condições de trabalho como consequência direta da reestruturação produtiva, notadamente ao se abordar a subcontratação nos moldes em que está sendo retratada.

Inicialmente, contudo, interessante é destacar que a precarização a que nos referimos reforçou as desigualdades já observadas no país, implementadas pelo crescimento da economia brasileira no período de 1970-1973.

O crescimento industrial da época sustentou-se, além de outros fatores macroeconômicos, na indústria pesada e na expansão do Departamento III (o setor de bens de consumo duráveis), e a verdadeira contenção dos salários reais, isto é, a penalização do crescimento dos salários reais dos trabalhadores.

A partir dessa política, reproduziu-se, num novo patamar histórico, a exclusão social, um dos traços estruturais do capitalismo no Brasil; mais que isso, "tornou a exclusão um elemento vital de seu dinamismo ${ }^{101 "}$.

A reestruturação produtiva serviu apenas como característica de aprofundamento das desigualdades e da exclusão social, precarizando as condições de trabalho, ou seja,

${ }^{101}$ OLIVEIRA, Francisco, 1972, p. 85, apud ALVES, Giovanni, p. 164. 
reduzindo os salários, os benefícios e as garantias sociais outrora fornecidas pela relação de emprego.

Logo, a precarização é resultado direto da tentativa do capital de expulsar, de uma vez por todas, o custo do trabalho de sua lógica produtiva, produzindo, como denominou o Prof. Giovanni Alves, a "subproletarização tardia".

Decorrente da cisão da classe operária, a subproletarização tardia é constituída pelos trabalhadores assalariados em tempo parcial, temporários ou subcontratados, seja na indústria, seja nos serviços interiores (ou exteriores) à produção do capital. Não é demais afirmar que ocorre a predominância da "informalização" nas relações de trabalho, o que nada mais é do que um eufemismo para a nova precariedade do trabalho assalariado.

E destaca o referido Professor ${ }^{102}$ :

O subproletariado tardio é uma parcela importante do "proletariado pós-industrial", um equivalente contemporâneo do proletariado sem direitos, oprimido e empobrecido" (o que Gorz denomina, por exemplo, "proletariado pós-industrial", é constituído não apenas pela subproletarização tardia, mas pelos desempregados estruturais) (Gorz, 1992). Ela é tão importante para a nova ordem do capital quanto o desemprego estrutural. É um aspecto dissimulado da nova exclusão social, do qual o desemprego estrutural é sua fratura exposta, muitas vezes, a discussão da quantidade de empregos sobrepõe-se à da qualidade dos novos postos de trabalho, ocultando, portanto, o problema da subproletarização tardia como um dos maiores problemas do mundo do trabalho no limiar do século XXI.

Na verdade, o que se tem sob as novas perspectivas da acumulação mundializada do capital é o desenvolvimento de uma cisão no mercado de trabalho, por meio da imposição plena da flexibilidade.

Neste sentido, a lógica do toyotismo impulsiona - com a noção de "fábrica enxuta", ou de "lean production" - o desenvolvimento de um complexo de pequenas

${ }^{102}$ ALVES, Giovanni. Op. Cit., p. 78. 
empresas de fornecedores e subcontratadas, em que o contrato social de trabalho é precário, ou não possui o mesmo estatuto social da empresa principal.

O aumento da subcontratação é um indicativo da subproletarização tardia, uma vez que a precariedade do emprego e do salário é o que caracteriza, de certo modo, a condição do trabalho assalariado nas pequenas unidades produtivas que circulam na órbita das corporações transnacionais.

Trata-se de uma estratégia de organização industrial voltada para o controle de trabalho e de emprego, adequada à nova época de crise de valorização do capital, na qual a instabilidade das relações econômicas impõe a constituição, pelas corporações transnacionais, de um "colchão ${ }^{103}$ " de pequenas empresas capazes de amortecer as inconsistências dos mercados.

E isso se reflete diretamente nos benefícios e nos salários pagos aos empregados das empresas subcontratadas.

A análise do DIEESE intitulada "Os trabalhadores frente à terceirização" (1993) apontou, como um dos principais efeitos da terceirização sobre o mundo do trabalho no Brasil, o ataque aos benefícios sociais - e salários - dos trabalhadores da empresa principal, que tendem a ser superiores aos vigentes nas firmas subcontratadas. Outras consequências consideradas perversas pelo DIEESE dizem respeito às condições ambientais e de segurança no trabalho, muitas delas consideradas insalubres.

A tabela abaixo demonstra a pesquisa realizada pelo Departamento em uma amostra de 40 empresas que realizam algum tipo de terceirização. São elas do ramo metalúrgico $(52,5 \%)$, eletricitário (15\%), companhias telefônicas $(12,5 \%)$, vestuário $(7,5 \%)$, bancos $(5 \%)$, processamento de dados $(5 \%)$ e petróleo $(5 \%)$.

De uma forma geral, o estudo aponta que a terceirização proporcionou às referidas empresas a dilapidação das conquistas dos trabalhadores, nos percentuais abaixo apontados ${ }^{104}$ :

Efeitos da terceirização sobre as condições de trabalho

Diminuição dos benefícios sociais $72,5 \%$

\footnotetext{
103 A expressão é do Prof. Giovanni Alves. Op. Cit., p. 81.

${ }^{104}$ ALVES, Giovanni. Op. Cit., p. 268-269.
} 


\begin{tabular}{|lc|}
\hline Salários mais baixos & $67,5 \%$ \\
Ausência de equipamentos de proteção/falta de segurança/ \\
insalubridade & $2,5 \%$ \\
Trabalho menos qualificado & $17,5 \%$ \\
Trabalho sem registro & $7,5 \%$ \\
Perda de representação sindical & $5,0 \%$ \\
\hline Jornada mais extensa & $5,0 \%$ \\
\hline
\end{tabular}

Fonte: Dieese, 1993

Não é difícil concluir, portanto, que a terceirização tem permitido às empresas contratantes livrarem-se dos encargos sociais e legais, além de não repassarem as conquistas dos acordos coletivos aos trabalhadores das empresas contratadas, ocasionando um verdadeiro enfraquecimento da representatividade sindical. Em outras palavras, a terceirização em geral (e nela compreendida a subcontratação) significa a redução de salários, perda de benefícios sociais e a implementação de condições de trabalho inseguras, que levam à maior exposição do trabalhador aos riscos de acidentes de trabalho.

A pesquisadora Liana Carleial, em atenção às empresas de sua análise, observou que são gritantes as diferenças de salários e benefícios entre as empresas subcontratantes e subcontratadas.

As maiores diferenças foram encontradas entre as empresas do ramo da eletroeletrônica e metalmecânica. Eis a tabela de comparação:

Quadro - Distribuição dos benefícios entre as empresas subcontratadas

Empresa do ramo A - eletroeletrônica ${ }^{105}$

\begin{tabular}{|c|c|}
\hline Subcontratante A & Subcontratada A3 \\
\hline \multicolumn{2}{|c|}{ Salário na produção } \\
\hline Piso: $2,88 \mathrm{SM}$ & Piso: $2 \mathrm{SM}$ \\
\hline Médio: 6,08 SM & Médio: $3 \mathrm{SM}$ \\
\hline \multicolumn{2}{|c|}{ Salário na administração } \\
\hline Piso: 5,21 SM & \multirow[t]{2}{*}{ Tem dois trabalhadores que ganham $10 \mathrm{SM}$} \\
\hline Médio: 17,94 SM & \\
\hline \multicolumn{2}{|c|}{ Direitos/benefícios auferidos pelos trabalhadores } \\
\hline Carteira assinada & Carteira assinada \\
\hline INSS & INSS \\
\hline Vale-transporte & Vale-transporte \\
\hline Restaurante & Vale-alimentação mais vale-mercado \\
\hline $\begin{array}{c}\text { Seguro-saúde (médicos + dentistas, dentro e fora } \\
\text { da empresa) }\end{array}$ & Seguro-saúde \\
\hline Participação nos lucros (para certos grupos) & Já pagaram alguma escola; nunca dissel \\
\hline
\end{tabular}

${ }^{105}$ Referência para o ano de 2001. CARLEIAL, Liana. Op. Cit., p. 162. 


\begin{tabular}{|c|c|}
\hline Seguro em grupo & \multirow{3}{*}{ não pagariam } \\
\hline Dias livres & \\
\hline $\begin{array}{c}\text { Programa de ajuda escolar (ajuda monetária } \\
\text { dependendo do nível salarial) }\end{array}$ & \\
\hline Creche & \\
\hline
\end{tabular}

Empresas do ramo D - metalmecânica ${ }^{106}$

\begin{tabular}{|c|c|}
\hline Subcontratante D & Subcontratada D2 \\
\hline \multicolumn{2}{|c|}{ Salário na produção } \\
\hline Piso: 3,1 SM & Piso: $3 \mathrm{SM}$ \\
\hline Médio: 5,94 SM & Médio: 4,5 SM \\
\hline \multicolumn{2}{|c|}{ Salário na administração } \\
\hline Piso: 4,34 SM & Piso: $4,5 \mathrm{SM}$ \\
\hline Médio: $19,40 \mathrm{SM}$ & Médio: $5 \mathrm{SM}$ \\
\hline \multicolumn{2}{|c|}{ Direitos/benefícios auferidos pelos trabalhadores } \\
\hline Carteira assinada & Carteira assinada \\
\hline INSS & INSS \\
\hline Vale-transporte & Vale-transporte \\
\hline Restaurante subsidiado: $95 \%$ pela empresa & \multirow[t]{6}{*}{ Seguro saúde } \\
\hline $\begin{array}{l}\text { Seguro-saúde (com assistência médica e } \\
\text { odontológica estendido para familiares) }\end{array}$ & \\
\hline Lanches para todos os funcionários & \\
\hline Convênios com supermercados e farmácias & \\
\hline Gratificação anual & \\
\hline Seguro de vida & \\
\hline
\end{tabular}

Inobstante se verificar a existência de carteira assinada, a diferença entre o salário auferido e os benefícios é abismal. O trabalhador da empresa subcontratada faz parte da estrutura produtiva da empresa subcontratante, entretanto, seus laços são estritamente formais, baseados em contratos comerciais, o que os distancia de sobremaneira da proteção oferecida pela categoria da referida subcontratante.

E isso não somente se reflete nos salários e benefícios, mas também no grau de escolaridade dos trabalhadores.

Inobstante o nível de especialização que muitas atividades requerem - a exemplo da indústria eletroeletrônica, dado o uso de tecnologias baseadas em microcomputadores - observa-se a redução do grau de instrução dos trabalhadores da subcontratada.

${ }^{106}$ CARLEIAL, Liana. Op. Cit., p. 166. 
De modo especial, na indústria de confecções, a totalidade dos trabalhadores possui primeiro grau incompleto, o que se justifica diante das tarefas semi-artesanais desenvolvidas no ramo, exigindo apenas o aprendizado do serviço em si, que é estritamente manual.

Nas demais subcontratadas o panorama é melhor; há alguma participação de trabalhadores com segundo grau completo e até nível superior.

A pesquisadora oferece um quadro geral comparativo a respeito de algumas das subcontratadas, com relação às subcontratantes ${ }^{107}$ :

Na rede A, inicialmente, observa-se uma diferença muito grande entre a empresa-mãe e as subcontratadas. Nestas, em duas delas [do total de três subcontratadas], $100 \%$ dos trabalhadores tem primeiro grau incompleto e na terceira, cuja situação é melhor, a média é representada por aqueles que têm só até a quinta série. Porém, há trabalhadores que apenas sabem ler e escrever.

Na rede B, na qual a qualificação dos trabalhadores da empresa-mãe é muito limitada, a qualificação formal de duas [do total de três subcontratadas] de suas subcontratadas chega a ser levemente superior à mãe. B2 tem $70 \%$ dos trabalhadores com primeiro grau ao passo que B3 tem $80 \%$ de seus trabalhadores nestas condições. Já a empresa subcontratada B1 tem o conjunto de seus trabalhadores com primeiro grau incompleto. A condição de acesso atual para cada uma das empresas não se constitui numa informação compatível com as exigências necessárias de uma organização do trabalho moderna. Apenas B2 acompanha B na exigência de primeiro grau completo. As demais priorizam a experiência sujeita à restrição de saber ler e escrever.

A rede comandada pela empresa $\mathrm{C}$ [que também tem três subcontratadas] não vai diferir das duas anteriores. C1 tem $35 \%$ de seus trabalhadores na produção com segundo grau completo e os demais com primeiro grau; C3 tem $85 \%$ de seus trabalhadores com primeiro grau. $\mathrm{O}$ requisito de qualificação que permite o acesso hoje às empresas é o primeiro grau completo em $\mathrm{C}$ e C3. As outras duas dividem-se entre priorizar a experiência e saber ler e escrever.

${ }^{107}$ CARLEIAL, Liana. O. Cit., p. 156-157. 
Não é demais concluir, muitas das vezes, que as subcontratadas são pseudoempresas. Na linguagem de um dos proprietários de uma subcontratada do ramo da eletroeletrônica, "eu sou um contratador de mão de obra".

E, diante deste cenário, não é demais afirmar que a qualificação e o treinamento dos empregados das subcontratadas é praticamente inexistente; não há interação entre a empresa-mãe e as subcontratadas na troca de tecnologias para o aprimoramento dos trabalhadores, tornando a rede enfraquecida.

Interessante notar que a autora utilizou-se da opinião do Sr. Vanderlei Quaquarini, vice-presidente do Soletroar (sindicato representante das eletroeletrônicas da região de Curitiba) para firmar algumas convicções.

A primeira delas é que a "subcontratação é um processo que lesa o trabalhador". O sindicato tem claro que as razões que levam a isto são "a concorrência e a busca pela redução de custos", porém acha que pode haver diferentes formatos. O mais pernicioso deles é aquele no qual a "empresa (ou a pseudo) é apenas uma executora de tarefas, e a grande empresa se responsabiliza por toda a matéria-prima, componentes, máquinas, etc. Este tipo, com certeza, só faz prejudicar o trabalhador. Logo: "essa empresa não vai mesmo conseguir dar ao trabalhador o que a grande empresa pode dar"108.

O quadro se torna ainda mais desanimador quando a reestruturação produtiva é levada às últimas consequências: trata-se, como se evidenciou, de um método eficiente de eliminação de postos de trabalho, de modo que o desemprego é crescente. Neste comento, a capacidade de criação de postos de trabalho na indústria decresce incisivamente.

Por conseguinte, o exército de trabalhadores dispensados poderá ser empregado em pequenas empresas subcontratadas, transformar-se-ão em trabalhadores por conta própria (o trabalhador em domicílio, por exemplo), passarão a trabalhar temporariamente com este tipo de vínculo (temporário), trabalharão sem carteira

${ }^{108}$ CARLEIAL, Liana. Op. Cit., p. 170. 
assinada e sem vínculo para algum patrão; poderão ainda constituir cooperativas de trabalho, ou então cairão no desemprego ${ }^{109}$.

A indústria de calçados no interior do estado de São Paulo, na cidade de Franca, a indústria da moda em São Paulo, a indústria de confecções pelo país, de microeletrônica, de metalurgia, são exemplos de descentralização produtiva baseada na subcontratação em plena operação, com as características de precarização das condições de trabalho, notadamente no que tange aos salários, higiene e segurança no trabalho; ampliação geográfica de sua fábrica; horizontalização (ou descentralização) produtiva; intensiva exploração da mão de obra; controle rígido da qualidade e quase nenhuma possibilidade de fiscalização dos órgãos governamentais, haja vista a disseminação da planta industrial, inclusive pelas casas dos operários.

A pesquisa desenvolvida pela socióloga Vera Lúcia Navarro, da Universidade de São Paulo, traz em seu bojo os impactos ocasionados no trabalho e no trabalhador pela reestruturação produtiva a partir da inserção da metodologia toyotista no Brasil.

Segundo a autora ${ }^{110}$, a indústria calçadista vem reproduzindo os modelos internacionais da reestruturação produtiva:

Nos últimos anos, o processo de reestruturação das indústrias de calçados de Franca tem se pautado mais pelo "enxugamento" do quadro de pessoal e pela crescente exploração do trabalho informal, precarizado, subcontratado, encoberto sob o manto do neologismo "terceirização", do que pela renovação de seu aparato tecnológico, pela adoção de novas tecnologias e novas formas de organização do trabalho no interior das fábricas.

Esses aspectos, revelados pela pesquisa, demonstram algumas das especificidades do processo de reestruturação produtiva em curso no país, que tem se pautado, em boa medida, pela simples exclusão de parte da força de trabalho empregada formalmente e sua posterior inclusão no mercado de trabalho através de formas precárias de exploração.

\footnotetext{
${ }^{109}$ CARLEIAL, Liana. Op. Cit., p. 199.

${ }^{110}$ NAVARRO, Vera Lúcia. A reestruturação produtiva na indústria de calçados de couro em Franca $(S P)$, in ANTUNES, Ricardo. Op. Cit., 2010, p. 67.
} 
O fato é que as políticas econômicas que autorizam essa possibilidade de externalização da produção, supostamente, chancelando-a, em prestígio à livre iniciativa e ao empreendedorismo, não mensuram as consequências sociais que a flexibilização dos direitos trabalhistas provenientes da reestruturação do sistema produtivo podem ocasionar, tais como o desemprego estrutural e o recrudescimento de uma massa de trabalhadores inseridos em condições de trabalho indignas, expostos aos mais diversos riscos e sem nenhuma proteção legal.

O trabalho da Professora de Sociologia da FEA-USP baseou-se no estudo empírico dos impactos causados pelas mudanças ocasionadas pela reestruturação produtiva, desde os anos 1980, na indústria de calçados de Franca-SP, e quais os impactos dessas transformações sobre o conjunto da força de trabalho ali empregada.

Alerta a pesquisadora ${ }^{111}$ que, independentemente das variações ascendentes e decrescentes do volume da produção ao longo da década de 1986-1996, a indústria calçadista francana extinguiu pelo menos 16.500 postos de trabalho nesse período, em sua enorme maioria em decorrência não da incorporação de maquinaria mais desenvolvida ao setor, e, sim, da adoção de estratégias de gerenciamento da produção pelas indústrias. Ao mesmo tempo em que se reduziram drasticamente os postos de trabalho nas indústrias, proliferaram diversas modalidades de trabalho em domicílio e nas bancas ${ }^{112}$.

Interessante trazer a análise empírica realizada pela pesquisadora, que demonstra que a subcontratação é meio de precarização das condições de trabalho em larga expansão.

A justificativa para tal reestruturação produtiva está baseada no preço das máquinas para o trabalho no couro ou no material sintético (matéria prima da indústria calçadista), que é deveras elevado.

\footnotetext{
${ }^{111}$ NAVARRO, Vera Lúcia, Op. Cit., p. 74.

112 Bancas: denominação dada às unidades produtivas prestadoras de serviço para as indústrias de calçados de Franca, especializadas em realizar determinadas etapas de confecção de calçados. Ex.: banca de pesponto, banca de corte, banca de chanfração, banca de ponteação etc. Na região produtora de calçados do Rio Grande do Sul, essas unidades produtivas são denominadas "ateliers". NAVARRO, Vera Lúcia, Op. Cit., p. 123.
} 
Nesse viés, somente as indústrias de grande porte podem adquiri-las, como é o caso da máquina de corte, baseadas na microeletrônica, restringindo seu uso por apenas aquelas empresas que possuem altos volumes de produção, categoria em que não se enquadra a grande maioria das indústrias francanas.

As grandes empresas calçadistas daquela cidade, nos últimos anos, vêm exigindo, contudo, que seus cortadores sejam habilitados tanto no corte manual quanto no corte mecânico. Entretanto, são poucas aquelas empresas que adotam programas de requalificação profissional de seus empregados, cabendo a estes requalificar-se por iniciativa própria.

Neste sentido, a maioria das empresas acaba por subcontratar o corte, que é repassado às bancas, podendo ser efetuado tanto pelo uso de máquinas (balancins) quanto manualmente. Esse processo ganha corpo a partir de 1993, quando começam a proliferar em Franca as bancas de corte.

O depoimento de um trabalhador sapateiro da região elucida o caso ${ }^{113}$ :

“De 1993 para cá, as empresas estão terceirizando o corte (...) Isso está ocorrendo porque o corte, depois do pesponto, é a operação que ocupa o maior número de pessoas dentro da fábrica”. (P.A.R., sapateiro e sindicalista)

Com a saída do corte para ser realizado fora das indústrias, as empresas calçadistas adotaram estratégias para controlar o uso dessa matéria prima, como a existência de funcionários que passaram a atuar fora da empresa, fiscalizando o trabalho nas bancas.

A seleção dos trabalhadores encarregados de realizar o corte em bancas ou em domicílio é rigorosa e é dada preferência a ex-funcionários, considerados de confiança pelas empresas calçadistas. Em geral, os donos de bancas de corte são ex-funcionários das empresas que contratam seus serviços, e ainda, há um agravante, em patente desrespeito à legislação trabalhista: algumas dessas bancas trabalham exclusivamente para determinada empresa, reforçando a existência de uma dependência econômica daquela estrutura empresarial externalizada.

${ }^{113}$ NAVARRO, Vera Lúcia, Op. Cit., p. 83. 
Juntamente às bancas, cresce também o trabalho de corte realizado em domicílio, executado por um único operário que trabalha sozinho em sua residência operando um balancim obtido, na maioria das vezes, por meio de empréstimo ou como forma de pagamento por ocasião de sua demissão da empresa.

No caso dos trabalhadores em domicílio, inobstante a existência de qualquer proteção legal do trabalhador, determina a empresa subcontratante que o maquinário deve ser instalado na casa dos trabalhadores, o que lhes impõe os custos das necessárias alterações que tais imóveis devem sofrer em suas estruturas, o que ocorre para o fim de que possam suportar os impactos provocados pela prensa hidráulica.

E assim observa a pesquisadora autora do trabalho ${ }^{114}$ :

A transferência das atividades do corte do interior das fábricas para o domicílio dos sapateiros, além de penalizar o trabalhador pela inexistência de contratos que garantam constância de fornecimento de trabalho, pela existência de intermediários que leva ao aviltamento dos salários, também o penaliza ao fazê-lo arcar com os custos de instalação do maquinário em sua residência. Em muitos casos, o funcionamento do balancim, além de colocar em risco a estrutura das residências, em sua maioria casas populares, também coloca em risco a saúde do trabalhador e de sua família. (...) O barulho e a trepidação provocados pelo balancim atingem não apenas o trabalhador e sua família, mas também os vizinhos.

$\mathrm{O}$ que mais gera preocupação nessa atividade, quando realizada em locais improvisados, é a falta de adoção de medidas de prevenção de acidentes, de fiscalização e manutenção desses equipamentos. As recomendações quanto à segurança no trabalho com prensas (podemos considerar o balancim como um tipo de prensa) indicam que uma série de medidas de inspeção e intervenção preventiva devem ser executadas periodicamente.

Não apenas a operação do corte acaba por ser subcontratada. Uma outra série de procedimentos, como o "tressê" (colocação de enfeites), a chanfradura e a costura, é realizado por bancas ou em domicílio, com a predominância do trabalho feminino em tais atividades.

${ }^{114}$ NAVARRO, Vera Lúcia, Op. Cit., p.87. 
O procedimento da subcontratação não é, contudo, diretamente com estas trabalhadoras, levando também a existência de um intermediário que retira, nas indústrias, grande quantidade de trabalho a ser realizada em domicílio, entrega as peças nas moradias das trabalhadoras, retorna, no dia seguinte, recolhendo o trabalho pronto e o leva de volta para as indústrias. Essa mesma pessoa efetua o pagamento das trabalhadoras, que é semanal, e é feito a partir do número de pares de peças executadas.

Por ser domiciliar, o trabalho tem caráter familiar, envolvendo muitas vezes parentes diversos, marido e filhos pequenos, ocupando, ainda, o dia todo das mulheres, prolongando-se à noite e aos finais de semana, sendo interrompidos apenas para os afazeres domésticos. Nenhum tipo de ferramenta, assim como equipamentos de proteção, é fornecido pela fábrica, cabendo às trabalhadoras adaptarem-se ao material e desenvolverem os próprios meios de trabalho nos sapatos.

Há de se considerar, ainda, que a atividade envolve condições insalubres de trabalho, como a fase de coladeira de peças. Isso porque a cola utilizada para colar as peças é acondicionada em pequenas bacias sem nenhuma proteção sendo inalada pela trabalhadora durante toda a jornada de trabalho.

À falta de fiscalização do Ministério do Trabalho se une também a necessidade contínua da produtividade, acompanhada da baixa remuneração. $\mathrm{O}$ ritmo de trabalho extenuante acaba por impedir que medidas de segurança como a adoção de recipientes fechados com pequenas aberturas para o pincel sejam adotadas.

A partir de meados dos anos 1980, a transferência da atividade do pesponto ${ }^{115}$ para as bancas passou a ser utilizada como recurso para reduzir os custos de produção.

E, à medida que cresceu essa modalidade de subcontratação de trabalho, cresceu também a informalidade do trabalho dos sapateiros, num quadro de agravamento das condições de trabalho e de maior exploração da força de trabalho, especialmente pela utilização do trabalho de mulheres, jovens e crianças, o que contribuiu sobremaneira para o barateamento da produção, num quadro mais precário das condições e das relações de trabalho. 
E não é demais observar que ${ }^{116}$ :

Nessas unidades produtivas, às crianças e adolescentes são reservados os serviços de mesa, que incluem as atividades de colar, dobrar e aparar, cortar linha, lixar peças de couto etc. Essas bancas, é bom lembrar, são montadas, em sua maioria, em locais improvisados, pouco ventilados, contando com iluminação inadequada, oferecendo pouca proteção aos trabalhadores. O ruído emitido pelas máquinas quando em operação superam os níveis de tolerância legalmente recomendados. Sob essas condições, o trabalho nos serviços de mesa, potencialmente prejudiciais à saúde, se agrava, dada a exigência do manuseio de produtos tóxicos, como cola e solventes.

Os serviços de costura igualmente deslocaram-se para fora da fábrica. Foi a partir dos 1970, quando as seções de costura manual começaram a ser desmontadas nas empresas de maior porte, a prática habitual era o repasse direto desse trabalho às costuradeiras, que deixavam as fábricas para trabalhar em seu domicílio, nos anos 1980, momento no qual a intermediação deixa de ser exceção para se tornar regra.

Trata-se de um trabalho mais especializado e, portanto, mais caro, uma vez que também exige mais do trabalhador, que acaba tendo sua própria produtividade limitada por sua capacidade física.

Isso porque a constante mudança de modelos que entram na linha de produção penaliza o trabalhador, tanto pelo fato de provocar quedas em seu rendimento, quanto pelo maior desgaste físico que proporciona e, consequentemente, pelos problemas de saúde daí decorrentes. São comuns os problemas de saúde, relacionados ao trabalho, que acometem os costuradores, principalmente aqueles provocados por esforços físicos repetitivos, problemas estes que não são assistidos pela previdência social, em vista da informalidade a que estão os trabalhadores sujeitos.

A indústria de confecção segue os mesmos parâmetros da indústria de calçados.

\footnotetext{
115 Pesponto: costura à máquina destinada a unir as peças que compõem o cabedal [parte superior do sapato]. O pesponto pode ter também função ornamental. Nota da autora, NAVARRO, Vera Lúcia. Op. Cit., p. 124.

${ }^{116}$ NAVARRO, Vera Lúcia. Op. Cit., p. 101.
} 
A ação do Ministério do Trabalho e Emprego tem se mostrado, contudo, eficiente medida de combate à precarização, em autêntica luta contra a exploração do trabalhador que se sujeita ao labor em condições análogas a de escravo.

Sua única liberdade é, muitas vezes, a de aceitar ser aliciado, haja vista que se constituem de trabalhadores estrangeiros, alienados à cultura e à legislação brasileira. Após isso, perde completamente sua identidade, passando a viver em condições subhumanas.

A reportagem da revista Época, produzida por Ana Aranha e denominada "Cerco às senzalas da moda" ${ }^{\prime 117}$ trouxe a realidade das grandes confecções nacionais que se utilizam da subcontratação para a produção de suas peças.

A crônica aborda a ação de auditores fiscais do trabalho, do Programa de Erradicação do Trabalho Escravo Urbano, que averiguaram, após denúncias, a condição de vida de trabalhadores bolivianos que costuravam peças de roupa em uma casa na cidade de São Paulo, em um bairro residencial, para as lojas Pernambucanas, marca nacional cujo faturamento em 2009 foi de $\mathrm{R} \$ 4,1$ bilhões.

Os trabalhadores tinham jornada de trabalho das $8 \mathrm{~h} 00$ às $22 \mathrm{~h} 00$, diariamente, recebendo, por peça, vinte centavos de real, o que os fazia jamais pararem a produção. Concentravam-se na residência em torno de 16 trabalhadores, apertados em 2 cômodos, sem janelas, de $6 \mathrm{~m}^{2}$ cada um.

As condições do imóvel são terríveis: fios elétricos pendurados no teto, sacos de roupa misturados à comida, inexistente qualquer ventilação. O que mais surpreende é que o mesmo local servia para abrigar os imigrantes. Dentre eles, constavam dois jovens menores de 18 anos e, ainda, três crianças, que circulavam entre as máquinas.

Inobstante se tratar de peças das Lojas Pernambucanas, as empresas eram formalmente separadas: os trabalhadores supostamente prestavam serviços para uma empresa subcontratada (Dorbyn), sem qualquer registro em carteira de trabalho ou benefício assegurado pela legislação do trabalho.

${ }^{117}$ Revista Época. ed. no 673/2011, Ed. Globo, 11/04/2012. 
Como consequência da operação, a subcontratante foi autuada em multa de $\mathrm{R} \$$ 2,2 milhões, em razão de manter trabalhadores em condições análogas à escravidão, conduta inclusive tipificada criminalmente. Ainda, os 16 trabalhadores receberam sua carteira de trabalho assinada, e o pagamento de verbas rescisórias: tudo em nome da subcontratada, contudo.

Estimam os auditores federais do trabalho e coordenadores do programa, Giuliana Cassiano e Luis Alexandre Faria, que só na cidade de São Paulo, existam 8 mil pequenas oficinas como esta que servia as Pernambucanas. "Só as empresas que alimentam a cadeia podem mudar essa lógica", afirma Giuliana, em discurso de combate às técnicas de reestruturação produtiva das confecções que levam à tamanha precarização do trabalho.

As lojas Marisa e Collins também já sofreram autuação pela mesma conduta e, segundo afirma Renato Bignami, coordenador nacional do Grupo Móvel de Fiscalização do Trabalho Escravo, "a Nike é uma das mentoras da terceirização do produto final para baratear custos".

Contudo, observa-se que há mudança na mentalidade das grandes confecções: não lhes é interessante manter sua imagem associada à exploração de pessoas ou ao trabalho escravo, de modo que vem investindo na transparência de seu relacionamento com os fornecedores e consumidores.

O que se denota é que a subcontratação pode tratar-se de um meio perverso do desmantelamento da proteção social causada pelo capital, uma vez que se retira da esfera de proteção legal o trabalhador contratado pela subcontratada, alijando-o por completo da classe trabalhadora e, muitas vezes, da própria noção de dignidade, como no caso acima.

As consequências à classe trabalhadora, infelizmente, não param por aí.

Alastram-se, ainda, pela consciência de classe e, em uma autêntica captura da subjetividade operária, por conseguinte, à sua representatividade sindical, abalando as estruturas da força e da coesão dos trabalhadores na luta por seus direitos, uma vez, que dada a característica de pequena e média empresa das empresas subcontratadas, o controle do capital é maior. 
Neste comento, é interessante o ensinamento do Professor Giovanni Alves ${ }^{118}$ :

Por isso, o crescimento da estratégia de terceirização, que se inclina a "enxugar" a montadora e a incentivar a proliferação das firmas subcontratadas, tende a debilitar, em última instância, o poder de barganha sindical da classe. Uma debilitação da classe no plano não apenas do estatuto salarial, mas principalmente do estatuto políticoideológico, tendo em vista que a possibilidade de constituição de uma consciência necessária de classe é maior nas grandes empresas do que nas firmas subcontratadas - notadamente nas pequenas e médias subcontratadas. A estrutura de organização sindical no Brasil constituiu-se, em termos históricos, no sentido "verticalizado"; incapaz, portanto, de organizar uma categoria assalariada cada vez mais "horizontalizada" pela nova (e radical) terceirização e de contribuir para a resistência da classe contra a sanha do capital.

Portanto, na perspectiva da luta de classes, a terceirização é um processo enfraquecedor, debilitante da classe operária, relegando-a à massa de manobra política. Seus objetivos constitucionais sufragados pela melhoria contínua das condições sociais de trabalho deixam de ser cumpridos, contribuindo para a precarização das condições de trabalho, haja vista a completa ausência de resistência da classe frente ao corte salarial e de benefícios.

\subsubsection{O dano social}

Interessante iniciar o estudo do presente tópico a partir de um trecho de artigo publicado pelo Prof. Jorge Luiz Souto Maior ${ }^{119}$, que sintetiza o que até agora estudamos:

O descumprimento deliberado do direito do trabalho pode ser considerado uma questão de interesse social, motivando a intervenção do Ministério Público, na medida em que, principalmente no que tange às regras de segurança e medicina do trabalho, esta atitude gera grande custo social, representado pelo acréscimo vertiginoso de doenças no trabalho e acidentes do trabalho, além de poder ser visto como uma forma de se estabelecer uma concorrência desleal entre as empresas, incentivando o "dumping” social numa perspectiva interna.

${ }^{118}$ ALVES, Giovanni. Op. Cit., p. 222-223.

${ }^{119}$ MAIOR, Jorge Luiz Souto. A Fúria. In: Revista LTr, São Paulo, Ano 66, no 11, p. 1287-1309. 
Não é difícil perceber no Brasil, neste sentido, nos dias atuais, o fenômeno que já há algum tempo é visto na Europa, o "dumping" social. O fenômeno vem trazendo crises econômicas domésticas intensas, sendo tido pela imprensa europeia ${ }^{120}$ como uma das piores consequências até então vistas decorrentes das novas estratégias de competição de mercados, em uma derradeira expansão de danos sociais, que merecem reparo.

Uma vez que somos um reflexo tardio das transformações industriais ocorridas no Velho Mundo, não é demais concluir que também o seremos quanto às consequências que tais transformações trazem, em proporções, contudo, proporcionalmente devastadoras, ante a ínfima proteção social trazida pelo Estado.

Nesse sentido, a matéria foi objeto de preocupação do Tribunal Superior do Trabalho, que editou o Enunciado $\mathrm{n}^{\mathrm{o}} 4$ da $1^{\mathrm{a}}$ Jornada de Direito Material e Processual da Justiça do Trabalho, organizada pela ANAMATRA, realizada em 2007, naquele Tribunal, cujo teor se transcreve:

"DUMPING SOCIAL". DANO À SOCIEDADE. INDENIZAÇÃO SUPLEMENTAR. As agressões reincidentes e inescusáveis aos direitos trabalhistas geram um dano à sociedade, pois com tal prática desconsidera-se, propositalmente, a estrutura do Estado Social e do próprio modelo capitalista com a obtenção de vantagem indevida perante a concorrência. A prática, portanto, reflete o conhecido 'dumping social', motivando a necessária reação do Judiciário Trabalhista para corrigi-la. O dano à sociedade configura ato ilícito, por exercício abusivo do direito, já que extrapola os limites econômicos e sociais, nos exatos termos dos arts. 186, 187 e 927 do Código Civil. Encontra-se no art. 404, parágrafo único, do Código Civil, o fundamento de ordem positiva para impingir ao agressor contumaz uma indenização suplementar, como, aliás, já previam os arts. 652 , 'd', e $832, \S 1^{\circ}$, da CLT ${ }^{121}$.

Inobstante não se observar do referido enunciado caráter vinculativo ou jurisprudencial, significa um avanço no sentido de uma percepção, pelo Tribunal

\footnotetext{
${ }^{120}$ LOFFREDO, Antonio. O novo cenário da descentralização produtiva, In: GAETA, Lorenzo y MOYA, Rosario Gallardo (Dir.). Los empresários complejos: un reto para el Derecho del Trabajo, Editorial Bomarzo S.L., Albacete, Espanã, 2010, p. 24.
} 
Superior, de que práticas tendentes a abolir ou a flexibilizar os direitos trabalhistas devem ser repelidas pelos magistrados e pela sociedade, em ordem a justamente preservar o Estado Social e o próprio capitalismo, mediante uma concorrência leal, em que todos respeitam as mínimas regras estabelecidas institucionalmente.

Logo, veda-se o enriquecimento a partir de uma ideologia de desconstrução de direitos, conduta esta que deve, ademais, ser penalizada civilmente, conforme estabelece o referido enunciado, diante do franco avanço à quebra do Contrato Social. Trata-se do respeito àquilo que arduamente conquistaram os trabalhadores ao longo de séculos de luta.

Seu desrespeito contumaz levaria, é forçoso concluir, às leis do mercado estabelecidas pelo século XVIII na Europa industrial, quando o trabalho em jornadas extenuantes e à base de salários miseráveis era plenamente admitido. Trata-se, conforme bem colocou o Professor acima citado, de uma "traição com nossos antepassados e também assumir uma atitude de descompromisso com relação às gerações futuras" ${ }^{122}$.

Visa-se, portanto, proteger primados constitucionais como a dignidade da pessoa humana e o valor social do trabalho, princípios fundamentais da República (art. $1^{\text {o }}$, incisos III e IV), os direitos trabalhistas, garantias fundamentais dispostas pela Constituição, e a própria livre iniciativa (art. 170), mas desde que esta se paute na valorização do trabalho humano e no respeito das garantias e princípios referidos, cumprindo a propriedade privada também o seu papel social, direito individual também cunhado como garantia fundamental (art. $5^{\circ}$, inciso XXIII).

Para o desenvolvimento da sociedade com base no respeito a tais garantias, eleitas, ademais, como valores essenciais em decorrência dos horrores vividos na Segunda Guerra Mundial, é necessário garantir sua eficácia.

E tal eficácia passa a ser garantida a partir do momento em que a sociedade não mais admite a flexibilização dos conceitos pertinentes aos direitos humanos, bem ainda àqueles de natureza social, como o direito ao trabalho digno.

121 Disponível em http://www.anamatra.org.br/jornada/anexos/ementas_aprovadas.pdf, acesso em 25/10/2009.

${ }_{122}$ MAIOR, Jorge Luiz. O Dano Social e sua Reparação. In: Revista IOB Trabalhista e Previdenciária, Ano XIX, no 225, p.58-72, março/2008, p. 58. 
Nesse exato contexto, segundo o Prof. Jorge Luiz Souto Maior, “as terceirizações, as subcontratações, falências fraudulentas, táticas de fragilização do empregado (como: falta de registro, transformação do trabalhador em pessoa jurídica, dispensas sem pagamentos de verbas rescisórias, justas causas fabricadas) têm imposto a milhões de cidadãos brasileiros um enorme sacrifício quanto a seus direitos constitucionalmente consagrados (...). ${ }^{123}$,

Numa perspectiva de coletividade, assim como aborda o presente trabalho, o desrespeito aos direitos sociais, especificamente ao direito ao trabalho e salário dignos, como reflexo imediato da precarização, inegavelmente traz como consequência dano à sociedade.

E o ordenamento traz, ainda, no texto constitucional, o dever do Estado, mediante legislação eficaz, em reprimir tais condutas empresariais.

É o que se extrai dos $\S \S 4^{\circ}$ e $5^{\circ}$, do art. 173 da Constituição da República:

Art. 173 .

(...)

$\S 4^{\circ}$. A lei reprimirá o abuso do poder econômico que vise à dominação dos mercados, à eliminação da concorrência e ao aumento arbitrário dos lucros.

$\S 5^{\circ}$. A lei, sem prejuízo da responsabilidade individual dos dirigentes da pessoa jurídica, estabelecera a responsabilidade desta, sujeitando-a às punições compatíveis com sua natureza, nos atos praticados contra a ordem econômica e financeira e contra a economia popular.

E, neste sentido, cumprindo com o contexto constitucional, rezam as regras do direito civil que também comete ato ilícito aquele que ao exercer seu direito, excede manifestamente os limites impostos pelo seu fim econômico e social - o abuso de direito.

${ }^{123}$ MAIOR, Jorge Luiz. O Dano Social..., p. 62. 
No que se refere ao abuso de direito, o Prof. Paulo Eduardo Vieira de Oliveira ${ }^{124}$ nos fornece singular explicação do conceito supra:

“(...) pode ocorrer que o agente pratique irregularmente um ato no exercício do direito, cometendo ato ilícito. Assim agindo, incorre-se no que a doutrina denomina "abuso de direito". Embora se atue dentro das prerrogativas que o direito concede, na se considera a finalidade social do direito subjetivo e, assim agindo, causa dano a outrem.”

Dita finalidade social é considerada para Josserand ${ }^{125}$, como a destinação daquele direito e o espírito da instituição, o que nos remete à ideia da conquista dos direitos sociais, bem ainda de sua elevação à categoria de direito fundamental, constitucionalmente protegido, ademais, por uma imutabilidade pétrea, conforme estabelece o inciso IV, do $§ 4^{\circ}$, do art. 60, da Constituição da República.

Por conseguinte, caberá ao agente providenciar sua indenização, conforme propugnam os supracitados artigos 187 e 927 do diploma civil brasileiro.

Trata-se não mais de restringir a necessária reparação ao agente individualmente prejudicado, senão levar em consideração toda a coletividade, os interesses metaindividuais que o direito, e em especial o direito do trabalho - visa tutelar.

E, para tanto, o jurista Mauro Cappelletti assim leciona, acerca da necessária efetividade da condenação judicial em indenização do dano social:

“(...) o juiz é legitimado a estender o âmbito da própria decisão, de modo a compreender a totalidade do dano produzido pelo réu, e, em geral, a decidir eficazmente mesmo às absent parties ou precisamente erga omnes. É a revolução dos conceitos tradicionais de responsabilidade civil e de ressarcimento dos danos (...). ${ }^{126,}$

E a reparação não só visa a proteção à coletividade de trabalhadores, mas também, como já ressaltado, aos demais empregadores. Aquele empregador que,

\footnotetext{
${ }^{124}$ OLIVEIRA, Paulo Eduardo Vieira. O dano social no direito do trabalho, 2 ed., São Paulo: LTr, 2010, p. 56.

125 JOSSERAND, Louis. De l'espirit des droits et de leur relativé, 1927, apud OLIVEIRA, Paulo Eduardo Vieira. $O$ dano social..., p. 58.

${ }^{126}$ CAPPELLETTI, Mauro. In: Formações sociais e interesses coletivos diante da justiça civil. Trad. Nelson Renato Palaia Ribeiro de Campos. Revista de Processo, São Paulo: LTr, 2002, p. 141, apud MAIOR, Jorge Luiz Souto. O Dano Social..., p. 64.
} 
valendo-se das agressões aos direitos do trabalhador, consegue auferir maior lucro, obtém indevida vantagem econômica com relação aos demais, que cumprem a legislação. Desta forma, estes últimos, verificando uma verdadeira vantagem no descumprimento dos direitos dos trabalhadores, igualmente pendem à prática de tal atitude. $^{127}$

Em grandes proporções, tem-se a precarização dos direitos sociais conquistados, numa perspectiva de lucratividade a todo custo, e em benefício exclusivo do capital.

Verifica-se, portanto, como trazido pelo Enunciado $\mathrm{n}^{\mathrm{o}} 4$, de verdadeiro "dumping" social. "Dumping" é proveniente do verbo "to dump", que em uma tradução livre significa "quebrar, jogar ao chão". O termo é originário das ciências econômicas, sendo que, com seu conteúdo técnico, significa a "venda de produtos a preços mais baixos que os custos, com a finalidade de eliminar concorrentes e conquistar fatias maiores de mercado" 128 .

E as práticas acima evidenciadas da subcontratação com os escusos interesses de ampliar a taxa de lucros e precarizar as condições de trabalho significam nada menos que o despejamento dos direitos sociais no lixo, no passado de uma conquista de direitos hoje desnecessários sob a ótica capitalista e flexibilizadora, já que o próprio capital se encarrega de formar as relações de trabalho à sua maneira, de acordo com a competitividade de cada um.

Nesse contexto de desagregação dos direitos sociais, hoje já estão mais arrojados os magistrados trabalhistas, seguindo a tendência de incorporar a tese supra às suas decisões, tendo-se em vista a agressão metaindividual que cada ofensa significa à legislação trabalhista.

Interessante trazer à baila, pela inserção histórica e pelo tom crítico, a sentença proferida pelo Juiz do Trabalho Substituto Adriano Antônio Borges, nos autos $\mathrm{n}^{\mathbf{o}}$ 0001895-78.2011.5.03.0138, em trâmite perante a 38 ${ }^{\mathrm{a}}$ Vara do Trabalho de Belo Horizonte (TRT da $3^{\mathrm{a}}$ Região).

${ }^{127}$ Como salienta Mario Garmendia Arigón, se "el atractivo que para el sujeto representa el no dar cumplimiento a la norma jurídica es superior a la aflicción que le provoca la amenaza de sanción, el 
Nos presentes autos, o autor postulava o reconhecimento da condição de bancário, por haver prestado serviços na condição de terceirizado ao Banco Ibi S.A. Banco Múltiplo. Restou devidamente comprovado, da instrução processual, que em verdade, o trabalhador desempenhava, travestido do cargo de promotor de vendas, funções desempenhadas pela categoria dos bancários.

Afora os direitos individuais reconhecidos ao reclamante, também decidiu o Ilustre Magistrado ${ }^{129}$, de forma poética:

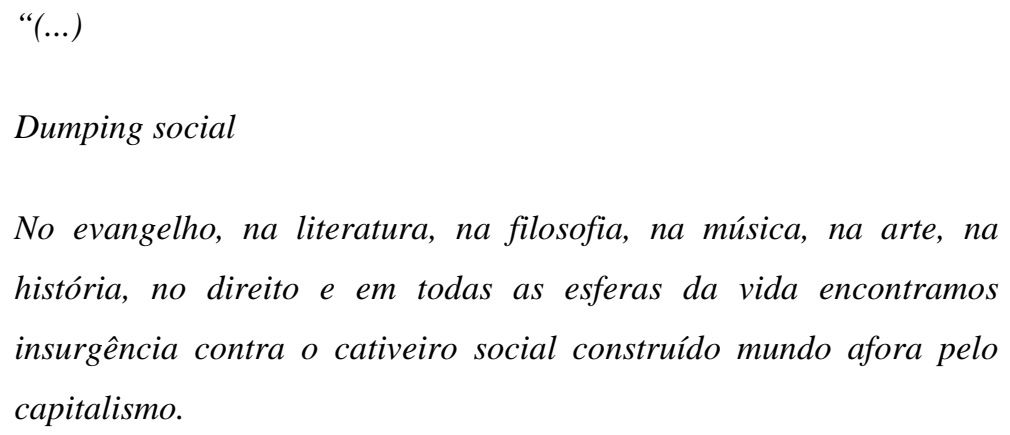

Estávamos bem, muito bem, numa sociedade primitiva fundada na liberdade, na igualdade, na fraternidade e no respeito à vida e à natureza quando o ocidente, em sua empreitada financiada pelos bancos, nos descobriu e, a partir de então, nos cobriu de misérias, de escravidão, de doenças capitais.

Pobre Caminha! que admirado com a altruísta nudez de nossas vergonhas, não percebeu (disso não posso ter tanta certeza) que a partir de então iniciava-se a verdadeira vergonha do aniquilamento de uma raça, de um embrião de nação que dormia no ventre esplêndido de um trópico inocente, puro, destituído de toda mazela, uma autêntica humanidade em flor.

Pobre brasileiro! que depois de mais de 500 anos ainda se vê tratado como mercadoria, como coisa, como um não ser pelo capital financeiro, que executando seu projeto de economicídio e de cárcere social, castra o reino da liberdade do homem, e o que é pior, na

efecto estimulante del acatamiento no se verificará" In: GARMENDIA ARIGÓN, Mario. Eficacia práctica de las normas laborales. Montevideo: FCU, 2005, p. 24/25.

${ }^{128}$ SANDRONI, Paulo. Dicionário de Economia, Série Os Economistas, Abril Cultural, 1985, p. 124.

${ }^{129}$ In: Terceirização ilícita gera condenação em $R \$ 50$ mil por dumping social, disponível em www.migalhas.com.br/Quentes/17,MI155925,51045-

Terceirização+ilicita+gera+condenacao+em+R \$+50+mil+por+dumping+social, acesso em 21/05/2012. 
maioria das vezes, com a ajuda do Estado, que trocou a política pela irracionalidade da matemática econômica.

É triste constatar que o grito do abolicionismo ainda não se fez ouvido; que a Casagrande ainda sobrevive da morte na senzala; que a dialética de Hegel entre o senhor e o escravo ainda não é possível; que brasileiro ainda só é bom na batata.

Basta! não podemos deixar que a injustiça social apodreça entre nós;que a democracia continue ameaçada pela força do capital;que a gananciosa guerra produtivista continue matando silenciosamente o povo e se escondendo através de leis comprometidas com o admirável mundo novo teatralizado pelo capital.

Ora, data venia, do ponto de vista de um Estado Social (que não me ouçam Mrs.Tatcher nem Ronald Regan), não dá para aceitar impunemente a conduta empreendida pela recdas, que comprometidas com a ditadura do capital, impuseram e continuam impondo escravidão à classe trabalhadora deste país.

Em sendo assim, entendendo legítimo material e processualmente o grito de qualquer excluído, e até porque o recte. é uma célula da sociedade brasileira, defiro, EM FAVOR DO FAT, que representa a coletividade de trabalhadores deste país, indenização de $R \$$ 50.000,00 (cinquenta mil reais) por prática do dumping social pelas recdas.”

Interessante ressaltar que o beneficiário da indenização referida pode ser a entidade governamental acima identificada, ou ainda alguma ONG que atue na área social.

Contudo, o Prof. Souto Maior acredita que, com fulcro no dever do resgate da autoridade do ordenamento, bem ainda do preceito fundamental da dignidade humana, tal indenização deve ser revertida em favor do autor da ação individual.

Para o Professor das Arcadas,

"não se trata de uma atitude que visa enriquecer indevidamente o autor. Seu propósito é inibir a repetição do ilícito; anular o lucro obtido pelo réu com a atitude de agressão ao ordenamento; e fazer crer 
a todos os demais empregadores, concorrentes do réu, que o respeito à ordem jurídica não lhes representa um prejuízo concorrencial. ${ }^{130}$,

Não há como negar, pelo tudo o que foi exposto, que as práticas adotadas pelos subcontratantes, levam à precarização das condições de trabalho e, por conseguinte, em uma análise holística de cunho social, ao alegado "dumping", em uma franca desvalorização da prática ética e sustentável do capitalismo.

Em segunda instância, a decisão supra restou confirmada quanto aos direitos individualmente conferidos ao trabalhador. Contudo, no que tange à indenização por "dumping" social, assim entendeu o MM. Desembargador Relator, Luiz Ronan Neves Koury, membro da $2^{\text {a }}$ Turma do Egrégio Tribunal Regional do Trabalho da $3^{\text {a }}$ Região:

$$
\text { “(..) }
$$

As demandadas não se conformam com a condenação ao pagamento de $R \$ 50.000,00$ ao Fundo de Amparo ao Trabalhador a título de indenização por dumping social.

Não há nos autos elementos de convicção que indiquem a intenção deliberada e reiterada do empregador em não cumprir as normas convencionais e trabalhistas, além da demonstração de vendas de produtos a preços tão baixos a não permitir a concorrência do mercado internacional, conseguidos, necessariamente, pela quase escravidão do trabalhador.

Além de não comprovada a vantagem para a reclamada, a indenização por dumping social não tem previsão legal.

Dou provimento para excluir da condenação a indenização por dano social. $^{131,}$,

Observamos, portanto, que o ativismo que se verifica na primeira instância pode não ser seguido pelo caráter conservacionista ainda dominante nos Tribunais.

Não há como se admitir que o "dumping social" esteja condicionado à verificação do dolo de uma empresa; trata-se de uma condição impossível de se ver

\footnotetext{
${ }^{130}$ MAIOR, Jorge Luiz Souto. O Dano Social..., p. 72.

${ }^{131}$ Acórdão publicado em 06/06/2012. Acesso em http://as1.trt3.jus.br/consulta/detalheProcesso1_0.htm?conversationId=850826, em 03/11/2012.
} 
implementada! Que empresário, em sã consciência, confessará que a agressão aos direitos trabalhistas ocorreu de forma deliberada e com o único fim de angariar lucros?

Ora, são agressões que não se podem simplesmente admitir diante da existência de um pacto social firmado, numa perspectiva do alcance cada vez maior de direitos trabalhistas, consoante determina o caput do art. $7^{\circ}$, da Constituição da República:

"São direitos dos trabalhadores urbanos e rurais, além de outros que visem à melhoria de condição social (...)"

Está, portanto, expresso na Carta Magna da República que cabe à sociedade e ao Estado a garantia e a melhoria dos direitos de todos os trabalhadores, e não do chancelamento de seu desrespeito e agressão. Não há dúvidas, diante de tudo o quanto exposto, que a decisão supra não está de acordo com o ordenamento jurídico e com os princípios primazes do direito do trabalho. O reclamante, contudo, não recorreu da decisão para o Tribunal Superior do Trabalho.

No que se refere à previsão legal, o abuso do direito insculpido como ato ilícito previsto no art. 187, do Código Civil, dispensa maiores digressões.

Pelo que se vê, ao menos do caso em questão, proveniente de um tribunal considerado de vanguarda, ainda é extenso o caminho e longa a batalha para se punir e ensinar os agressores do direito do trabalho, cumprindo-se, dessa forma, com o caráter binomial que a teoria da indenização prevê hodiernamente. 


\section{ANÁliSE JURÍDICA DA SUBCONTRATAÇÃO - RESPONSABILIDADE DO SUBCONTRATANTE}

\subsection{Brasil}

A subcontratação, tal qual estudada no presente trabalho, conforme destacado, é tida como uma variação do fenômeno da terceirização.

A terceirização, por sua vez, é em si um fenômeno econômico que remete o direito do titular da unidade produtiva a eleger sua técnica de gestão e se vincula com o direito de propriedade e de liberdade de empresa, consagrado pelas normas constitucionais (arts. $5^{\circ}$, caput e 170), o que impediria uma censura jurídica pelo mero fato de externalizar algum segmento de sua produção.

Nesse contexto, uma vez que ora com aquela se confunde, ora se torna um fenômeno díspar, três são as perspectivas jurídicas pelas quais são abordadas.

Observemos cada uma delas.

\subsubsection{Isenção}

O Prof. Sergio Pinto Martins ${ }^{132}$, partindo da perspectiva de que a subcontratação pode ser entendida como a delegação a terceiros de partes da atividade da empresa, sustenta que se trata a subcontratação, indiretamente, de um contrato de empreitada, nos termos do art. 455 da CLT e dos arts. 610 a 626 do Código Civil, diferindo-se, portanto, da terceirização de serviços, a cujas consequências jurídicas subordina-se de forma diversa a empresa contratante.

Nesse esteio, o caput do art. 455 da CLT assim prescreve:

Art. 455. Nos contratos de subempreitada responderá o subempreiteiro pelas obrigações derivadas do contrato de trabalho que celebrar, cabendo, todavia, aos empregados, o direito de reclamação contra o empreiteiro principal pelo inadimplemento daquelas obrigações por parte do primeiro.

\footnotetext{
${ }^{132}$ MARTINS, Sérgio Pinto. Flexibilização das condições de trabalho. 3 ed., São Paulo, Atlas: 2004, p. 95-96.
} 
No caso da subcontratação, a inteligência do artigo supra é feita de forma que o empreiteiro é representado pela empresa subcontratada, não havendo, entretanto, a figura do subempreiteiro, ressaltando-se, portanto, a característica daquele agente social que requer a produção de um resultado, de um fim, (a obra), sendo este o dono da obra. Os empregados do empreiteiro, desta forma, nada poderiam exigir do dono da obra, é dizer, a empresa subcontratante.

Em suma, como define Catharino ${ }^{133}$, apresentando, ainda, as principais características da empreitada:

Conceito de empreitada (locatio conductio operis faciendi): é o contrato pelo qual uma pessoa, condutor-empreiteiro, mediante remuneração, obriga-se a realizar uma obra, para outra, sua dona. (...)

Ao conductor-empreiteiro cabe a execução da obra, realizando-a sozinho, auxiliado por terceiros, em relação ao seu dono, ou, simplesmente, dirigindo outro(s) que a paga; o conductor-empreiteiro tanto pode ser pessoa física quanto jurídica; como a obrigação do empreiteiro é a de conduzir a obra, seu trabalho é autônomo em relação a quem a paga; tratando-se de obra a ser realizada, o contrato de empreitada é a termo resolutivo ou final.

A empresa subcontratada, na qualidade de empreiteira, é quem irá, portanto, contratar formalmente os empregados, os quais, por sua vez, trabalharão em benefício da atividade da empresa subcontratante.

A antiga redação da Orientação Jurisprudencial nº 191 , da $1^{\text {a }}$ Seção de Dissídios Individuais do C. Tribunal Superior do Trabalho, anterior à Resolução n 175/2011, reforçava ainda mais tal entendimento:

\section{Dono da obra. Responsabilidade}

Diante da inexistência de previsão legal, o contrato de empreitada entre o dono da obra e o empreiteiro não enseja responsabilidade solidária ou subsidiária nas obrigações trabalhistas contraídas pelo empreiteiro, salvo sendo o dono da obra uma empresa construtora ou incorporadora.

${ }^{133}$ CATHARINO, José Martins. Op. Cit., Compêndio..., p. 278. 
E, nesse contexto, a subcontratação, comumente vislumbrada enquanto contrato de facção, adquire forma de um contrato de cunho eminentemente civil entre as empresas, não se verificando a terceirização ou a subcontração, mas apenas uma relação cliente-consumidor entre ambas, em que aquele encomenda determinada atividade produtiva (obra) pagando-se apenas pelas unidades produzidas.

Diante de tal fator preponderante, ou seja, a existência de uma relação empresarial diversa, baseada em uma obra certa e determinada, não haveria que se falar em terceirização de atividades.

O TRT mineiro ( $3^{\mathrm{a}}$ Região) apresenta em seus anais jurisprudenciais recentíssimos os seguintes julgados:

(...) CONTRATO DE FACÇÃO. AJUSTE DE NATUREZA CIVIL. RESPONSABILIDADE SUBSIDIÁRIA DO CONTRATANTE. DESCABIMENTO. INAPLICABILIDADE DA SÚMULA N $\mathrm{N}^{\circ}$ 331, IV, DO TST. O contrato de facção, hipótese contemplada neste processado, tem seu objeto restrito ao fornecimento, pela empresa contratada, de produtos prontos e acabados à empresa contratante, para que esta, a seu turno, os utilize na sua própria atividade econômica. Esta modalidade contratual, de caráter essencialmente civil, não se destina à obtenção de mão-deobra, tampouco a regular a prestação de serviços propriamente dita, não se podendo cogitar a presunção de culpa in vigilando, ou in elegendo, da empresa adquirente de tais produtos, que, nesse contexto, não pode ser responsabilizada subsidiariamente pelos créditos trabalhistas devidos aos empregados da empresa contratada. É inaplicável às hipóteses de verdadeira facção o entendimento contido na Súmula no 331, IV, do c. TST, sendo imperativo, para tanto, que a prestação laboral e a atividade da empresa de facção não sofram ingerência direta da contratante, e que não se realizem com exclusividade para uma só beneficiária. TRT $3^{\mathrm{a}}$ Região - Minas Gerais. $8^{\mathrm{a}}$ Turma, autos n 0001373-47.2010.5.03.0086 RO, Rel. Des. Marcio Ribeiro do Valle, publicação 13/03/2012.

O TRT paranaense ( $9^{\mathrm{a}}$ Região) também coaduna do mesmo entendimento:

CONTRATO DE FACÇÃO - GRUPO ECONÔMICO SÚMULA 331 - NÃO ENQUADRAMENTO. Trata, o contrato de 
facção, de ajuste que tem por objeto a entrega de produtos acabados, a serem elaborados no âmbito da empresa de facção, por seus próprios empregados, sem que exista ingerência por parte da contratante. No caso, as atividades desta diferiam, em essência, das desenvolvidas pela empregadora, realidade extraída da prova produzida, bem assim, dos objetos sociais contratualmente previstos. Responsabilidade da contratante que não se reconhece, portanto, seja na forma solidária ou subsidiária, já que a regular prática do contrato de facção, como ocorrido, não se confunde com a formação de grupo econômico (art. $2^{\circ}, \S 2^{\circ}$, da CLT), nem atrai a incidência da Súmula 331, do C. TST. Recurso da ré a que se dá provimento. TRT $9^{a}$ Região (PR). RO $n^{\text {o }}$ 6822010303905 PR 682-2010-303-9-0-5, 6 ${ }^{\mathrm{a}}$ Turma, Rel. $^{\mathrm{a}}$ Des $^{\mathrm{a}}$. Sueli Gil El-Rafihi, publicação: 14/08/2012.

Profícua é a produção de julgados neste mesmo sentido pelo TST, conforme se extrai das ementas abaixo:

RECURSO DE REVISTA. PROCEDIMENTO SUMARÍSSIMO. RESPONSABILIDADE SUBSIDIÁRIA. CONTRATO DE FACÇÃO. O contrato de facção é um contrato tipicamente cível, na área industrial, que possui natureza híbrida, o qual não se confunde com a terceirização de mão de obra, uma vez que não há ingerência da empresa contratante sobre o sistema de produção da empresa contratada, pelo que é inaplicável a responsabilidade subsidiária prevista na Súmula $n^{\circ} 331$, IV, do TST. Recurso de revista de que não se conhece.(RR - 107400-41.2007.5.12.0011, Relatora Ministra: Kátia

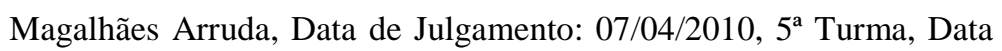
de Publicação: 16/04/2010)

RECURSO DE REVISTA. ADMISSIBILIDADE. CONTRATO DE FACÇÃO. RESPONSABILIDADE SUBSIDIÁRIA. SÚMULA No 331, IV, DO TST. INAPLICABILIDADE. Trata-se a hipótese de contrato de facção, de natureza civil, onde a indústria contrata empresa para o fornecimento de produtos prontos e acabados, não para o fornecimento de mão-de-obra, com intermediação de empresa prestadora de serviços. Nesse contexto, o entendimento desta Corte é no sentido de ser inaplicável a Súmula $\mathrm{n}^{\circ}$ 331, IV, do TST. Precedentes. Recurso de revista conhecido e provido. (RR - 6180060.2008.5.12.0011, Relator Ministro: Emmanoel Pereira, Data de

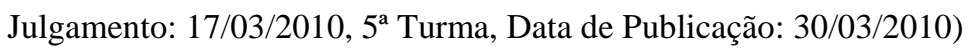


RECURSO DE REVISTA. RESPONSABILIDADE SUBSIDIÁRIA.

CONTRATO DE FACÇÃO. SÚMULA N $\quad$ N $^{\mathrm{o}} 331$.

INAPLICABILIDADE. O contrato de facção firmado entre as partes para fornecimento de produtos acabados é de natureza civil e inexistindo exclusividade na prestação de serviços, bem como ingerência da tomadora na execução das atividades produtivas, evidencia-se a impossibilidade de configuração de culpa in vigilando ou in eligendo da tomadora dos serviços, pressupostos para imputação de responsabilidade subsidiária. Assim, não se tratando de intermediação irregular de mão-de-obra, torna-se inaplicável à hipótese a orientação contida na Súmula no 331, IV. Precedentes desta Corte. Recurso de revista de que não se conhece. (RR - 6120059.2007.5.12.0048, Relator Ministro: Guilherme Augusto Caputo Bastos, Data de Julgamento: 17/03/2010, $7^{\text {a }}$ Turma, Data de Publicação: 30/03/2010)

RECURSO DE REVISTA - CONTRATO DE FACÇÃO RESPONSABILIDADE SUBSIDIÁRIA - INAPLICABILIDADE DA SÚMULA N $\mathrm{N}^{\circ} 331$, IV, DO TST. Percebe-se que a hipótese ora em deslinde é de contrato de facção, de natureza civil, em que a indústria contrata empresa para o fornecimento de produtos prontos e acabados, não para o fornecimento de mão de obra, com intermediação de empresa prestadora de serviços. Nesse contexto, não se aplica a orientação que emana da Súmula $n^{\circ} 331$, IV, do TST, cujo objetivo é o de evitar que o empregado seja prejudicado em face da inadimplência da empresa prestadora dos serviços, tendo como pressuposto a existência de culpa in eligendo e in vigilando, premissas não estabelecidas no acórdão recorrido. Recurso de revista conhecido e provido. (RR - 67440-64.2007.5.12.0048, Relator Ministro: Luiz Philippe Vieira de Mello Filho, Data de Julgamento: 24/02/2010, $1^{\text {a }}$ Turma, Data de Publicação: 05/03/2010)

Segundo o Prof. Irany Ferrari, referida hipótese tem por objetivo a entrega de produtos prontos e acabados elaborados pela empresa faccionista (dentro de seu âmbito físico, inclusive), por seus empregados. 
E, assim sendo, "a empresa que adquire referidos produtos não pode ter nenhuma responsabilidade sobre os empregados da produtora, uma vez que estes últimos nada têm a ver com a empresa compradora. ${ }^{134,}$

Difere-se, ademais, do contrato de terceirização porquanto este tipo de contrato visa à realização de trabalhos envolvendo empresas tomadora e prestadora de serviços, em cuja situação os empregados desta ficam à disposição daquela, com vistas ao desempenho de atividades contratadas. O contrato de facção por sua vez, dada sua característica, mantém sua autonomia, não possuindo nenhuma ingerência da empresa cliente.

Desta forma, em se tratando de uma relação eminentemente comercial - sem qualquer implicação trabalhista, sob a ótica de seus defensores -, nenhum tipo de responsabilidade caberia à empresa subcontratante.

\subsubsection{Subsidiariedade}

Há juristas que defendem, contudo, que a subcontratação é, em seus fundamentos práticos, o mesmo que a terceirização de serviços, devendo ser tratada de acordo com o escopo abordado pela jurisprudência consolidada do TST, vale dizer, a responsabilidade subsidiária prevista na Súmula 331.

Interessante demonstrar que referido entendimento jurisprudencial surgiu a partir do marco inicial de intermediação de mão de obra exposto pela Lei nº 6.019/74, que, como sabido, regulamenta o contrato de trabalho temporário.

Neste caso legal específico, havia pertinência entre o serviço prestado pelo empregado da empresa de trabalho temporário e aquele visado pela empresa tomadora, de maneira que o trabalhador encaixava-se à estrutura central desta última, de modo a substituir mão de obra efetiva e permanente diante de uma necessidade transitória ou do acúmulo extraordinário de serviços $\left(\right.$ art. $2^{\circ}$ ). Entretanto, o diploma legal veda que a terceirização em questão, pela própria natureza do trabalho prestado, ultrapasse os 3 meses previstos (art. 10).

\footnotetext{
${ }^{134}$ FERRARI, Irany. Contratos de facção e terceirização - distinção para efeito de responsabilidade. In: LTr Suplemento Trabalhista, São Paulo, 2010, Ano 46, no 036/10, p. 160.
} 
Não foi, contudo, a Lei $\mathrm{n}^{\circ}$ 6.019/74 a primeira manifestação legislativa a autorizar a externalização de mão de obra, tendo o Decreto no 200/1967 inaugurado referida prática para a administração pública, descentralizando-se atividades meio, já com o intuito de redução de custos.

Entretanto, foi a Lei 5.645/70 que pareceu dar os primeiros passos para o que se verifica hoje com a redação da Súmula 331, do TST: referido diploma legal regulamentou a reforma da administração pública, possibilitando a transferência de atividades denominadas de "execução" para terceiros, como limpeza, conservação, custódia, transporte. Surgiu, então, a terceirização dos serviços.

Posteriormente, foi o segmento de segurança e de vigilância de instituições bancárias e de transportes de valores, conforme as disposições da Lei n ${ }^{\circ}$ 7.102/83 (art. 10). A Lei $n^{\circ} 8.863 / 94$ ampliou o âmbito de aplicação dos dispositivos desta última, possibilitando a contratação de empresas terceirizadas para serviços de vigilância por qualquer instituição, pública ou privada, além de segurança de pessoas físicas, transporte e transportes de carga.

O entendimento jurisprudencial, até então, mostrava-se restritivo, tendo o TST editado, por meio da Resolução $n^{\circ}$ 04/1986, a Súmula 256, a qual consagrava a ilegalidade da "contratação de trabalhadores por empresa interposta" em situações não abrangidas pelas Leis $\mathrm{n}^{\circ}$ 6.019/74 e 7.102/83 “formando-se o vínculo empregatício diretamente com o tomador dos serviços".

Referido enunciado estabelecia nítida diferença entre a intermediação de mão de obra (tratada pela Lei $n^{\circ}$ 6.019/74, como legítimo instrumento de colocação de trabalhadores temporários na atividade fim da empresa) e a terceirização de serviços.

Eis o texto do antigo entendimento jurisprudencial:

CONTRATO DE PRESTAÇÃO DE SERVIÇOS. LEGALIDADE (cancelada) - Res. 121/2003, DJ 19, 20 e 21.11.2003

Salvo os casos de trabalho temporário e de serviço de vigilância, previstos nas Leis nº 6.019, de 03.01.1974, e 7.102, de 20.06.1983, é ilegal a contratação de trabalhadores por empresa interposta, 
formando-se o vínculo empregatício diretamente com o tomador dos serviços.

Observa-se que o Tribunal Superior, diante das tentativas do capital em desviar-se da relação de emprego, tentou restringir a contratação de serviços terceirizados aos casos previstos nas leis acima, considerando-se como ilegal as demais hipóteses, uma vez que tal modalidade mostrou-se prejudicial aos direitos do trabalhador.

Em 1993, nos auspiciosos anos da transformação industrial brasileira, o Tribunal acompanhou a abertura comercial, flexibilizando os direitos do trabalhador por meio da redação da Súmula 331 (Resolução no 23/1993), cuja composição assim inicialmente se fixou:

\section{No 331. CONTRATaÇÃo de PRESTaÇão de SERViÇOS. LEGALIDADE.}

I - A contratação de trabalhadores por empresa interposta é ilegal, formando-se o vínculo diretamente com o tomador dos serviços, salvo no caso de trabalho temporário (Lei no 6.019, de 03.01.1974).

II - A contratação irregular de trabalhador, através de empresa interposta, não gera vínculo de emprego com os órgãos da Administração Pública Direta, Indireta ou Fundacional (art. 37, II, da Constituição da República).

III - Não forma vínculo de emprego com o tomador a contratação de serviços de vigilância (Lei $n^{\circ} 7.102$, de 20.06.1983) e de conservação e limpeza, bem como a de serviços especializados ligados à atividademeio do tomador, desde que inexistente a pessoalidade e a subordinação direta.

IV - O inadimplemento das obrigações trabalhistas, por parte do empregador, implica na responsabilidade subsidiária do tomador dos serviços, quanto àquelas obrigações, desde que hajam participado da relação processual e constem também do título executivo judicial.

A Resolução $n^{\circ}$ 174/2011 atribuiu nova redação ao item IV, tendo, ainda, inserido os itens V e VI à sua redação, conforme se observa do texto: 
CONTRATO DE PRESTAÇÃO DE SERVIÇOS. LEGALIDADE (nova redação do item IV e inseridos os itens V e VI à redação) Res. 174/2011, DEJT divulgado em 27, 30 e 31.05.2011

I - A contratação de trabalhadores por empresa interposta é ilegal, formando-se o vínculo diretamente com o tomador dos serviços, salvo no caso de trabalho temporário (Lei $n^{\circ} 6.019$, de 03.01.1974).

II - A contratação irregular de trabalhador, mediante empresa interposta, não gera vínculo de emprego com os órgãos da Administração Pública direta, indireta ou fundacional (art. 37, II, da CF/1988).

III - Não forma vínculo de emprego com o tomador a contratação de serviços de vigilância (Lei n ${ }^{\circ}$ 7.102, de 20.06.1983) e de conservação e limpeza, bem como a de serviços especializados ligados à atividademeio do tomador, desde que inexistente a pessoalidade e a subordinação direta.

IV - O inadimplemento das obrigações trabalhistas, por parte do empregador, implica a responsabilidade subsidiária do tomador dos serviços quanto àquelas obrigações, desde que haja participado da relação processual e conste também do título executivo judicial.

V - Os entes integrantes da Administração Pública direta e indireta respondem subsidiariamente, nas mesmas condições do item IV, caso evidenciada a sua conduta culposa no cumprimento das obrigações da Lei n. ${ }^{\circ}$ 8.666, de 21.06.1993, especialmente na fiscalização do cumprimento das obrigações contratuais e legais da prestadora de serviço como empregadora. A aludida responsabilidade não decorre de mero inadimplemento das obrigações trabalhistas assumidas pela empresa regularmente contratada.

VI - A responsabilidade subsidiária do tomador de serviços abrange todas as verbas decorrentes da condenação referentes ao período da prestação laboral. (grifo nosso)

Inobstante a dura realidade dos terceirizados do serviço público, que agora têm o ônus de demonstrar a inadimplência e a culpa do administrador público neste evento, denota-se a nítida manutenção do caráter neoliberal dos anos 90, mesmo diante dos 
princípios constitucionais de isonomia entre os trabalhadores e constante melhoria das condições de trabalho e das teorias progressistas dos direitos sociais.

Autorizou-se a terceirização de atividades meio de forma, portanto, indiscriminada, abrindo uma comporta doutrinária e jurisprudencial de discussões sobre referida expressão que até os dias de hoje não se fechou.

A terceirização reconhecida pelo Tribunal é, portanto, aquela em que "não há controle da atividade pelo tomador, não há subordinação direta e não há delegação de atividade fim, mas de meio. O que não impede o tomador de fiscalizar esse serviço ${ }^{135, "}$

Reconheceu-se a responsabilidade subsidiária do tomador de serviços de maneira irrestrita, mas a discussão acerca do que se tratava como atividade meio ou fim mostra-se inócua, uma vez que traz um ranço eminentemente subjetivo.

De acordo com a autora Tábata Gomes Macedo de Leitão ${ }^{136}$, o entendimento propugnado pelo Tribunal contraria texto expresso de lei e, portanto, de acordo com referido critério, haveria ilegalidade na contratação de trabalhadores terceirizados:

\begin{abstract}
“(...) a relação de emprego se estabelece pela natureza não eventual da prestação de serviços e não pela sua ligação direta ou indireta com o objeto central das atividades desenvolvidas. Nesses termos, o critério instituído pela Súmula 331, estabelecendo permissão jurisprudencial para prática da terceirização, por meio da divisão em atividade-fim ou atividade-meio, contraria dispositivo legal expresso.
\end{abstract}

Cumpre ressaltar que todas as atividades prestadas de maneira contínua a uma empresa estão ligadas, embora indiretamente, à realização da atividade central de tal empresa, sendo, portanto, necessárias e indispensáveis, caso contrário, por tudo que vimos até aqui, certamente já teriam sido eliminadas em prol do aumento dos lucros.
\end{abstract}

\footnotetext{
${ }^{135}$ CADIDÉ, Iracema Mazetto. A subordinação estrutural no contexto da terceirização. In: Revista LTr Legislação do Trabalho, Ano 74, nº 05, Maio/2010, p. 570.

${ }^{136}$ LEITÃO, Tábata Gomes Macedo de. A terceirização no contexto de eficácia dos direitos fundamentais. Dissertação de Mestrado. São Paulo: Faculdade de Direito da Universidade de São Paulo, 2012, p. 165-166.
} 
Pensemos, por exemplo, no caso da limpeza: em termos econômicos pode-se dizer que, na atividade bancária, a limpeza não está diretamente relacionada com o objeto central, com a atividade-fim da empresa. Não obstante, todos os trabalhadores têm direito a um ambiente adequadamente limpo, conforme artigo 200 da Consolidação das Leis do Trabalho ou mesmo de acordo com a Norma Regulamentadora $\mathrm{n}^{\mathrm{o}} 24$ do Ministério do Trabalho. Além disso, o ambiente de trabalho - figurando na ordem social na Constituição de 1988 - foi elevado ao patamar de direito fundamental. Portanto, em termos jurídicos, não se pode afirmar que os serviços de limpeza não constituam atividade essencial." Nesse sentido, sendo atividade permanente, essencial e concorrendo para realização do objeto central, é parte integrante da empresa e há de ser realizada por meio de contratos diretos com os trabalhadores, conforme regra do ordenamento justrabalhista."

De acordo com sua pesquisa, em se verificando a característica de atividade permanente e essencial, concorre para a realização do objeto central da empresa contratante, de modo que deve ser realizada por trabalhadores cuja relação jurídica a ser configurada é a de vínculo de emprego direto com a contratante.

O critério atribuído pelo TST acaba por gerar distorções na interpretação do direito, distanciando-o cada vez mais da realidade de tentativa do distanciamento do capital para com os meios de produção.

Interessante, nesse sentido, trazer à baila caso fático envolvendo a companhia NESTLÉ BRASIL LTDA., grande fabricante de chocolates no Brasil e a empresa de pequeno porte (EPP) OFICINA DO CACAU LTDA.

Conforme se verifica do ANEXO 1, as empresas celebraram contrato cujo objeto (Cláusula Primeira) constituía-se em “industrialização (fabricação elou acondicionamento), fornecimento e entrega dos Produtos que NESTLÉ vier a lhe encomendar com base neste Contrato, nas quantidades e dentro da periodicidade que lhe sejam requeridas por esta última, serviços estes que serão executados nas instalações industriais da OFICINA DO CACAU...".

E referida fabricação, para o fim de manter os padrões da subcontratante, deveria seguir os parâmetros estabelecidos, de acordo com os "conhecimentos" transmitidos por 
esta última, seguindo-se, inclusive o denominado NQS (Nestlé Quality System), assumindo a subcontratada integralmente a responsabilidade do processo de industrialização e a qualidade dos produtos (Cláusula Quarta).

Inobstante a ingerência e a notória transferência dos riscos da grande empresa à pequena empresa subcontratada, observa-se, ainda, a exigência de exclusividade na produção (Cláusula décima), vedando-lhe expressamente a venda de produtos a terceiros, obrigação que inclusive durará até depois de terminada a vigência do contrato.

Observando uma possível fraude na contratação, empregado da empresa OFICINA DO CACAU ajuizou demanda trabalhista perante a vara do trabalho da cidade de Jacareí, São Paulo (TRT 15 ${ }^{\mathrm{a}}$ Região, $\mathrm{n}^{\mathrm{o}}$ 0000889-03.2011.5.15.0138), postulando, em suma, o pagamento de verbas rescisórias que não percebeu quando de sua dispensa, em agosto de 2011, pela empresa NESTLÉ, já que trabalhava em sua atividade-fim.

Em sentença (ANEXO 2), o Juízo de primeira instância entendeu pela parcial procedência da demanda, subsumindo os fatos apresentados pela reclamante ao item IV da Súmula 331, TST, de modo que deverá a empresa NESTLÉ responder subsidiariamente pelos créditos derivados da relação de emprego mantida entre o trabalhador e a empresa OFICINA DO CACAU, créditos estes frustrados diante da impossibilidade de manutenção da empresa por motivos financeiros.

A responsabilidade em questão, embora questionada mediante recurso ordinário interposto pela NESTLÉ, restou mantida, conforme acórdão também anexo (ANEXO $3)$.

Tal caso é paradigmático no sentido de se demonstrar o que se colocou no Capítulo 1, ou seja, na tentativa de ver-se livre dos meios de produção, o capital externaliza suas atividades produtivas, exigindo, para tanto, que lhe seja exclusiva a prestação dos serviços (nesse caso, a facção), fulminando-lhe de morte, contudo, ao fim do contrato. Trata-se da pseudo-empresa referida pela pesquisadora Liana Carleial.

Ocorre, contudo, que ambas as decisões, seja de primeira como de segunda instância, utilizam-se do critério abordado pela Súmula, observando se a terceirização ocorreu na atividade-fim ou atividade-meio da empresa. O que se constatou é que, 
diante do objeto social da empresa subcontratante, deveria a atividade prestada pela empresa OFICINA DO CACAU enquadrar-se como atividade-fim, e, portanto, conforme alertou o Juízo de primeiro grau, à míngua de pedido formulado pelo trabalhador, não se estabeleceu o vínculo direto de emprego com a empresa subcontratante.

Contudo, são diversos os entendimentos propagados pela jurisprudência no sentido de se verificar apenas a responsabilidade subsidiária entre as empresas componentes da rede ou do contrato de facção, uma vez que se admite sua eventualidade, tal qual obra certa.

Em outro caso paradigmático deste E. Tribunal (ANEXO 4), as empresas HBR e SAFETLINE figuravam no polo passivo de diversas reclamações trabalhistas; a primeira como empregadora formal dos trabalhadores, e aquela, como real beneficiária de sua mão de obra.

As atividades desempenhadas pela empresa terceirizada consistiam-se, segundo provas produzidas nos autos $\mathrm{n}^{\mathrm{o}} 0016200-96.2009 .5 .15 .0140$, em:

“a) a primeira reclamada, HBR, produzia cabedais (sapatos sem sola) exclusivamente para a segunda ré, Safetline;

b) a Safetline ingeria nos negócios da HBR, tecendo exigências técnicas diretamente associadas ao modo de produção dos cabedais comprados;

c) a Safetline fornecia tecnologia e maquinário à HBR para fabricação dos produtos que comprava com exclusividade;

d) a Safetline oferecia treinamento aos empregados da HBR.”

Nesses termos, os Desembargadores componentes da $4^{\mathrm{a}}$ Câmara (2 ${ }^{\mathrm{a}}$ Turma) do Egrégio Tribunal, acompanhando a Relatoria do Exmo. Desembargador José Pedro Camargo Rodrigues de Souza, decidiram pela condenação da segunda ré SAFETLINE na responsabilização subsidiária frente aos créditos inadimplidos da trabalhadora autora da demanda (acórdão publicado em 01/07/2011).

Baseou-se o E. Relator na ocorrência inequívoca da culpa in vigilando da tomadora de serviços; tendo deixado de exercer seu dever de vigilância sobre a empresa 
prestadora de serviços frente suas obrigações trabalhistas, o que redundou no inadimplemento de verbas devidas à autora da demanda.

Outrossim, entendeu que o presente caso não se trata de contrato de facção, mas de mero contrato de prestação de serviços.

Interessante demonstrar que dentro do mesmo contexto fático, como se verificará no tópico abaixo, entendeu a mesma Câmara pela aplicação da responsabilidade solidária entre as mesmas empresas.

Contudo, ainda no sentido da responsabilidade subsidiária quando se observa a externalização da unidade produtiva, têm-se os seguintes julgados:

EMPRESA SIDERÚRGICA. TERCEIRIZAÇÃO RELACIONADA A SUBPRODUTO DA ATIVIDADE PRINCIPAL DA TOMADORA. RESPONSABILIDADE SUBSIDIÁRIA CONFIGURADA. INAPLICABILIDADE DA OJ 191 DA SDI-1. INCIDÊNCIA DA SÚMULA 331 DO C. TST. Pela análise dos dados fáticos do processo, aliados a informações colhidas na internet, constata-se que o reclamante lidava diretamente com a escória resultante da atividade principal da tomadora, em decorrência do contrato de prestação de serviços de manutenção firmado entre as rés. Outrossim, os serviços do demandante se davam, integralmente, no âmbito da recorrente, onde cumpria o total da sua jornada laboral,realizando as tarefas objeto da pactuação entre as reclamadas. Postas estas premissas, ab initio, entendo que a hipótese refoge à figura do dono da obra, pelo que, inaplicável a OJ nº 191 da SDI-I do C.TST. Extrai-se das informações fáticas colhidas, que a escória constitui subproduto das atividades siderúrgicas de produção de aço, e deve ser extraída com regularidade porque envolve matéria usualmente presente na siderurgia, além de se tratar de produto tóxico, que exige as devidas cautelas e procedimento técnico na lida. Logo, ainda que não se trate de produto objeto do interesse primordial da ré, que é a produção de aço, a escória, como subproduto siderúrgico, exige constante atividade com vistas à sua retirada dos fornos. A manutenção dos fornos, assim, é uma exigência natural e constante decorrente das atividades de siderurgia. Ainda que a ré terceirize tais atividades, não se pode negar sua responsabilidade direta por elas, vez que elas não se comparam à eventual necessidade de uma prestação de 
serviços de manutenção, como consertos de maquinários ou reparação episódica de construção civil, estas sim, hipóteses que guardariam adequação à figura do dono da obra. No caso concreto, a situação passa longe desse enquadramento, afigurando-se como atividade terceirizada decorrente da precípua produção de aço, possuindo típico viés de terceirização de serviços, na qual a mão-de-obra envolvida permanece tempo integral da jornada laboral e durante todo o pacto havido com a prestadora de serviços no âmbito da recorrente. Nesse contexto, não se pode excluir que o aproveitamento dos préstimos do reclamante integravam a rotina da atividade encetada pela tomadora, já que é não só do seu interesse, mas sua obrigação, fazer a manutenção e retirada da escória de seus fornos, em decorrência da atividade principal encetada pela indústria do aço. Assim, entendo quea hipótese atrai a incidência da responsabilidade subsidiária, como tomadora dos serviços do autor, nos termos da Súmula n 331 do C.TST. TRT $2^{\mathrm{a}}$ Região - São Paulo, $4^{\mathrm{a}}$ Turma, Processo $\mathrm{n}^{\mathrm{o}}$ 20120020295, Recldas: Usinas Siderúrgicas de Minas Gerais S.A., Reframon Montagem e Manutenção de Refratários Ltda; Reclte: Fernand Rodrigues dos Santos. Rel. Ricardo Artur Costa Trigueiros, publicação 06/06/2012.

RESPONSABILIDADE SUBSIDIÁRIA - SUPOSTOS. A jurisprudência unívoca da Superior Corte visa a não deixar a parte autora ao desabrigo da proteção legal se o "tomador de serviços", embora não sendo o empregador direto, é legal e indiretamente responsável pelos débitos trabalhistas da empresa prestadora de serviços no beneficiar-se das atividades do trabalhador contratado pela empresa interposta. A questão dos autos estampa duas situações bem distintas. A primeira, com limite em 28.02.2003, quando havia entre as Reclamadas apenas uma relação comercial, advinda de compra e venda de peças e componentes automotivos, que não encorpa subsidiariedade, já que não se cuida de terceirização, não sendo a segunda Reclamada a tomadora dos serviços da primeira, cuja produção era destinada também a outras empresas. A segunda, após a transferência do maquinário e do pessoal da empregadora para os recintos da segunda Reclamada, por força de termo de compromisso celebrado entre as empresas, quando a segunda Reclamada passou a se beneficiar da produção que lhe era destinada com exclusividade, o que se deu até a rescisão do termo de compromisso em 08.04.2003, estando caracterizada 
a terceirização para efeitos de reconhecimento de responsabilidade subsidiária da segunda Reclamada, neste curto interregno. TRT $3^{\mathrm{a}}$ Região - Minas Gerais. $6^{\mathrm{a}}$ Turma, Processo $\mathrm{n}^{\mathrm{o}}$ 00778-2003-029-03-00-5, Recldas: Maxion Componentes Automotivos S.A.; Ilger Componentes Automotivos Industriais Ltda.; Recltes: Rodrigo de Souza Novaes e Vicentina Gregório da Silva. Rel $^{\mathrm{a}}$. Emilia Facchini, publicação 04/09/2003.

Cumpre destacar, de acordo com o que acima se verifica, que a subcontratação é entendida, a partir de uma interpretação malfadada do direito e do caso concreto, como terceirização lícita, o que se depreende justamente pela interpretação subjetiva que a expressão "atividade-meio" pode carregar consigo.

Desta feira, são inúmeros os julgados que, diante do mesmo contexto probatório de externalização produtiva, da produção em rede ou do contrato de facção, se dividem em entendimentos, muitas vezes dentro de um mesmo Tribunal, como se noticiou alhures.

Passemos à análise da responsabilidade solidária, também aplicada frente ao mesmo caso fático.

\subsubsection{Solidariedade}

No ano de 2011, o Tribunal Superior do Trabalho promoveu um evento direcionado à comunidade científica dos juristas e à sociedade, buscando novas soluções ao antigo problema da responsabilidade empresarial diante da terceirização: tratou-se da Audiência Pública sobre a Terceirização, realizada nos dias 4 e 5 de outubro ${ }^{137}$.

Referido evento trouxe estudiosos, sindicalistas, presidentes de associações empresariais e professores para o fim de se travar um diálogo multifocal acerca da terceirização, abordando seus aspectos econômicos, sociais e jurídicos.

Abrilhantou referido evento a explanação do Professor e Desembargador aposentado do TRT da $3^{\text {a }}$ Região (Minas Gerais) Márcio Túlio Viana, em 4 de outubro de 2011, que nos trouxe opinião diversa acerca da empresa em rede, ipsis litteris:

137 Para ter acesso completo ao evento e aos documentos lá produzidos, acesse: http://www3.tst.jus.br/ASCS/audiencia_publica/index.php. 
"Falar em terceirização é falar de duas coisas, a palavra tem dois sentidos. Podemos falar em terceirização referindo-nos, por exemplo, a uma fábrica de automóveis que usa uma outra fábrica de autopeças para construir o seu veículo. Mas podemos falar também falar em terceirização nos referindo a uma empresa que fornece a outra trabalhadores para fazer conservação e asseio. No primeiro caso, a fábrica de autopeças produz, fabrica um produto acabado. É a empresa em rede. Não tem a ver, a meu ver, com a Súmula 331 do nosso TST. A norma que regula essa hipótese é o grupo de empresas, o art. $2^{o}, \S 2^{\circ}$ da CLT. Pois bem, muitas vezes, como sabemos, as empresas do grupo precarizam, as pequenas empresas com frequência fazem o "serviço sujo" para as grandes. Como são menos visíveis, podem precarizar direitos trabalhistas $e$ oferecer contratos mais apetitosos para as grandes.

Qual seria a solução então? A meu ver, ampliar a o entendimento do que seja um grupo econômico, para proteger melhor o trabalhador. Naturalmente, os interesses comerciais do país não podem se sobrepor aos interesses, também do país, humanitários. $^{138,}$

Trata-se, portanto, de uma terceirização externa, na qual, para o eminente Professor, nada mais seria do que a existência de um grupo econômico de empresas, definido no parágrafo $2^{\circ}$ do art. $2^{\circ}$ da Consolidação das Leis do Trabalho. Neste instituto, observa-se claramente laços de dependência, controle e direção entre as distintas unidades que se criam para realizar a atividade econômica.

O Prof. Paulo Eduardo Vieira de Oliveira afirma ser essencial a autonomia das empresas participantes, mas também a possibilidade ou não de subordinação à uma empresa principal; neste sentido, o conceito de grupo de empresas admite a existência de empresas coligadas, sem uma necessária relação de dominação, mas de coordenação - caso da rede de empresas. Neste caso, imprescindível é a unidade de comando, que é

\footnotetext{
${ }^{138}$ Transcrição da fala do Professor efetuada pela autora. Acesso direto ao vídeo: http://www.youtube.com/watch?v=1BVGDStCjQ\&list=PL1A193424E8F196C6, acesso em 29/08/2012.
} 
existência de controle destas empresas por uma ou algumas pessoas físicas em comum $^{139}$.

Neste caso, uma vez que tutelado pela lei, não há dúvida de que os direitos dos trabalhadores serão solidariamente atribuídos a todas as empresas do grupo, ainda que tenha o trabalhador prestado serviços para a empresa que produzia especificamente apenas um item componente de um produto da empresa principal, subcontratante.

Interessante ressaltar que tampouco importará, para a finalidade da análise das consequências trabalhistas, o fundo formal, é dizer, o contrato comercial a que estão vinculadas as empresas e pelo qual a relação de subcontratação se apresenta, podendo se observar contratos como os denominados por arrendamento de obra, obra certa, empreitada, consultoria, transferência de tecnologia, fornecimento, ou ainda, situações de fato propriamente não denominadas, mas em que nitidamente observa-se o contrato de facção, a produção em rede, bastando depreender da situação o fornecimento de produtos ou matérias-primas que se agregarão no produto final da empresa contratante, ou principal.

Sua análise a partir do ponto de vista jurídico, portanto, é de um contrato civil ou comercial, nos termos do Código Civil, celebrado entre duas empresas, onde uma delas se compromete a fornecer (subcontratada), conforme destacado elo economista e pesquisador Éolo Marques Pagnani, peças, componentes, subconjuntos ou conjuntos, e que se agregarão ao produto final da outra (subcontratante) mediante pagamento.

Conforme já explanado alhures, uma vez que não se pode concluir que o contrato de facção ou a produção em rede trate-se sempre de terceirização de atividadefïm, mormente em razão do ranço subjetivo de tal conceito, interessante levar em consideração que ainda assim não seja considerado (o que levaria à aplicação do item I, da Súmula 331, TST), haverá a inequívoca existência do grupo de empresas, de modo a se decretar a responsabilidade solidária das empresas envolvidas na produção do bem.

Entendemos, entretanto, que ainda que não haja a deliberada intenção de encobrimento de terceirização ilícita - e, portanto, intermediação de mão de obra -

139 OLIVEIRA, Paulo Eduardo Vieira de. Campo de Aplicação do direito do trabalho - sujeitos: empregador e empregado. In: MAIOR, Jorge Luiz Souto e CORREIA, Marcus Orione Gonçalves (org.). 
mediante a utilização do contrato de facção, é certo que, como colocou de forma indistinta o preclaro Professor Márcio Túlio Viana, deve-se responsabilizar as empresas envolvidas na empreitada de forma solidária. Isto porque, conforme depreendeu-se, trata-se da utilização de trabalhadores engajados para a elaboração, facção, de um único produto, de propriedade da empresa principal, que será por esta vendido, lhe proporcionando lucros acima dos que obteria se não descentralizasse sua produção.

De modo que, precarizando a relação de trabalho mediante a flagrante ingerência econômica na atividade produtiva da subcontratada, obtém indevidamente vantagens financeiras, devendo responsabilizar-se paritariamente à empresa que apenas e tão somente empregou formalmente aqueles empregados. Por tais razões, a existência do contrato de facção tal qual seu conceito - entrega de produtos acabados - não exclui a necessária aplicação da responsabilidade patrimonial da empresa subcontratante.

Interessante destacar, contudo, que esse não é o entendimento majoritário dos tribunais brasileiros, destacando, contudo, que somente se verificará aludida responsabilidade se houver o manejo fraudulento do contrato de facção.

Neste sentido, a ementa extraída do voto de relatoria da Desembargadora Ana Paula Pellegrina Lockmann, do TRT da $15^{\mathrm{a}}$ Região, assim considerou sobre o contrato de facção, envolvendo as mesmas empresas SAFETLINE e HBR:

(...) TERCEIRIZAÇÃO DA ATIVIDADE-FIM. CONTRATO DE FACÇÃO. IRREGULARIDADE. RESPONSABILIDADE SOLIDÁRIA. Tendo o suposto contrato de facção - figura híbrida criada pela indústria, especialmente utilizada no setor têxtil, que reúne elementos da terceirização e da empreitada - sido utilizado com vistas a encobrir contratação irregular de empresa interposta para a consecução da atividade-fim do empreendimento, na medida em que a empresa contratante atribuiu parte do seu processo produtivo a outra empresa, que atuou exclusivamente e sob a sua ingerência na confecção do seu produto semi-acabado, cujo arremate e embalagem ficaram por sua conta, resta cristalina a fraude perpetrada, consoante artigo $9^{\circ}$ da CLT, devendo a mesma responder solidariamente pelas verbas deferidas à obreira na origem, atendendo aos limites do pedido. Recurso provido. TRT $15^{\text {a }}$ Região - Campinas, SP. $3^{\text {a }}$ Turma, $5^{\text {a }}$ 
Câmara, Rel ${ }^{\mathrm{a}}$. Desa ${ }^{\mathrm{a}}$. Ana Paula Pellegrina Lockmann, autos $\mathrm{n}^{\mathbf{o}}$ 0193400-27.2008.5.15.0140, Recldas: H B R INDÚSTRIA E COMÉRCIO DE CALÇADOS LTDA. - EPP - SAFETLINE EQUIPAMENTOS DE SEGURANÇA LTDA.; Recltes: DÉBORA FERNANDA DE SOUZA, publicação 06/05/2011.

E o Egrégio Tribunal Superior ressoa no mesmo sentido:

RECURSO DE REVISTA. CONTRATO DE FACÇÃO. GRUPO ECONÔMICO. RESPONSABILIDADE SOLIDÁRIA. O Regional, com base na prova dos autos, entendeu configurado o grupo econômico, consignando que restou evidenciado ingerência, não só econômica, mas também nas atividades produtivas, não se tratando de regular contrato de facção. Entendimento contrário demandaria exame da prova. Óbice da Súmula 126 do TST. Recurso de revista não conhecido. RR n ${ }^{\text {o }}$ TST-RR-63900-71.2008.5.12.0048, $8^{\text {a }}$ Turma, Rel $^{\text {a }}$. Min $^{\text {a }}$ Dora Maria da Costa. Reclte: KARILEISE DA SILVA NASCIMENTO; Recldas: IBERPUNTO INDÚSTRIA E COMÉRCIO TÊXTIL S.A., DU PANO CONFECÇÕES LTDA., MANTEIGAS CONFECÇÕES LTDA., TALHARIA E MODELAGEM TRAÇO FORTE LTDA. e CATIVA TÊXTIL INDÚSTRIA E COMÉRCIO LTDA. E OUTROS. Publicação: 05/08/2011.

(...) CONTRATO DE FACÇÃO - ASSUNÇAO DO PARQUE EMPRESARIAL - GRUPO ECONÔMICO - RESPONSABILIDADE SOLIDÁRIA. Diante do contexto fático em que ficou demonstrado o desvirtuamento do contrato de facção originalmente firmado entre as reclamadas, passando a segunda reclamada a assumir administrativamente os negócios da primeira, inarredável a sua condenação solidária na lide ante a formação de grupo econômico, nos termos do artigo $2^{\circ}, \S 2^{\circ}$, da CLT. (...). TST-RR-6117/2002-902-02$00.28^{\text {a }}$ Turma, Rel ${ }^{a}$. Mina ${ }^{\mathrm{a}}$. Dora Maria da Costa. Reclte: Geraldo Gonçalves de Sales; Reclda: PRIMO TEDESCO S.A. Publicação: $14 / 08 / 2009$.

É de vanguarda, portanto, o entendimento propugnado pelo Excelso Professor Márcio Túlio Viana que, diante de suas retinas fatigadas, pode presenciar no Tribunal em que atuou, inúmeros casos fáticos como o ora analisado, e dos quais se concluiu pela existência inequívoca do vilipêndio dos direitos trabalhistas e a propagação das 
mazelas sociais decorrentes da precarização das condições de trabalho trazidas pela subcontratação.

A análise da subcontratação conforme demonstrada, também deve ser empreendida por meio de uma figura ainda mais progressista, que é a subordinação reticular ou estrutural, admitindo que os empregados da empresa subcontratada devem ser, em verdade, também formalmente vinculados à subcontratante, tendo seus contratos de trabalho firmados com esta última.

\subsubsection{Vínculo de emprego - subordinação estrutural e reticular}

A externalização da produção ocorre na situação em que uma empresa, denominada ora como principal, confie ou encarregue a outra empresa, a subcontratada, por meio de um acordo civil ou comercial, a realização de uma obra ou serviço produtivo (ou parte destes), que será executado com sua própria organização de meios econômicos, materiais, técnicos e humanos, assumindo seu risco empresarial. Em regra, subcontrata à outra, peças, componentes, subconjuntos ou conjuntos, e que se agregarão ao seu produto final.

Nesse contexto, afirma o Prof. Jorge Luiz Souto Maior, que, para tornar nebulosa a identificação da relação de emprego, a grande empresa, que antes trazia todos os seus empregados numa mesma linha de produção, alastrou referida linha para além dos limites físicos da fábrica ${ }^{140}$.

Trata-se, conforme traçados os limites desse trabalho, da aludida subcontratação, que se manifesta indiscutivelmente pela externalização produtiva mediante contratos de facção e a produção em rede, pulverizando-se a produção para que se confira um falso aspecto de que cada uma dessas unidades produtivas se trate de uma unidade empresarial autônoma e específica, desvinculando-se o capital, como afirma o referido professor, "em aparência” do trabalho.

Neste sentido, não raro se observa o trabalho explorando o trabalho, conforme aludido alhures, ex-empregados agora referidos como empresários ou gestores, passam

${ }^{140}$ MAIOR, Jorge Luiz Souto. Curso de Direito do Trabalho..., p. 137. 
a coordenar o trabalho de outros trabalhadores, tudo em benefício da empresa principal, oferecendo-lhe o produto acabado para que o explore economicamente no mercado.

Logo, o direito do trabalho como pensado pelos intérpretes mais restritivos do conceito de subordinação - arraigados ao pensamento neoliberal do distanciamento do Estado da relação de trabalho - não teria, em tese, incidência sobre tais trabalhadores que, figuradamente, estão no primeiro degrau de exploração de uma pirâmide, sendo a grande empresa seu topo.

Todavia, diante do que apresentamos como objetivo do direito do trabalho, notadamente o de figurar como verdadeiro instrumento de justiça social, hábil a não permitir o retorno das condições de trabalho vistas nos séculos XVIII e XIX, lhe cabe a árdua tarefa de, mediante o que nos permite a ciência jurídica, também fazer com que os trabalhadores dessa pirâmide sejam a contento integrados à sua proteção.

E essa proteção não se trata meramente de se aplicar a responsabilidade subsidiária ou solidária às empresas envolvidas mas, em um caso de exploração exclusiva de uma empresa, consoante visto pelo exemplo NESTLÉ x OFICINA DO CACAU acima, é de efetivar as normas sociais mediante a declaração do vínculo de emprego entre todos os empregados desta última empresa com a empresa principal, inclusive dos sócios proprietários que, mesmo constituídos como gestores de uma pessoa jurídica, também ostentam, na verdade, a função de empregados, com o diferencial de que assumem o risco do empreendimento.

Igualmente, coloca o Professor Souto Maior ${ }^{141}$ caso paradigmático, em cujo trecho de sua obra se observa:

\footnotetext{
"Nas situações, portanto, em que, por exemplo, costureiras trabalhem em suas residências para uma outra pessoa [realidade inclusive estudada no presente trabalho], ou empresa, que "compra" daquela o produto acabado para vendê-lo, livremente, no mercado [verdadeiro contrato de facção], há de se reconhecer que tais costureiras são empregadas da empresa final e que o intermediário, mesmo constituído como pessoa jurídica, também o é, com um aspecto ainda pior que é o de ter sido utilizado como empregador aparente, tendo,
}

${ }^{141}$ Idem, p. 138. 
inclusive, que arcar com parcela do risco econômico que era próprio da grande empresa."

Ocorre, contudo, que os juristas mais argutos, podem valer-se da premissa de que tal declaração de vínculo de emprego é claramente contra legem, uma vez que está em desacordo com o conceito de subordinação previsto pela CLT (art. $3^{\circ}$ ). Desta forma, carecendo um dos requisitos do vínculo de emprego, tal tese seria descabida, retornando-se ao conceito do distanciamento do capital ao trabalho.

Para refutar tal argumento, trazemos, inicialmente, a irretorquível proposição defendida pela autora Tábata Gomes Macedo de Leitão, com a qual concordamos integralmente (vide Capítulo II, item "Subsidiariedade"), e que defende que, uma vez em se tratando a atividade subcontratada de atividade essencial e permanente para a realização do objeto principal da empresa, ilegal se verificaria o seu repasse a terceiros, exegese esta do próprio art. $3^{\circ}$ da CLT.

Contudo, é dever demonstrar também, à guisa do quanto preceitua o caput do art. $7^{\circ}$ da Constituição da República ${ }^{142}$ e o princípio protetor justrabalhista do in dúbio pro operário, que a interpretação da subordinação aludida no art. $3^{\circ}$ da CLT deve encarar outras perspectivas além daquelas já evidenciadas, de modo a garantir a efetividade dos direitos sociais aos trabalhadores ora abordados.

Neste sentido, assim evidencia o referido artigo:

Art. $3^{\circ}$ - Considera-se empregado toda pessoa física que prestar serviços de natureza não eventual a empregador, sob a dependência deste e mediante salário.

A norma positivada fornece-nos substratos caracterizadores da relação de emprego - pessoa natural que presta serviços com pessoalidade, de forma habitual, onerosa e sob a dependência de um empregador.

Referida dependência poderia ser analisada sob o ponto de vista econômico, já que a maioria da massa trabalhadora necessita de seus empregos para sobrevivência

\footnotetext{
${ }^{142}$ Art. $7^{\circ}$. São direitos dos trabalhadores urbanos e rurais, além de outros que visem à melhoria de sua condição social: (...)
} 
própria e de seus familiares, contudo, tal regra não pode ser tida como requisito à formação do vínculo de emprego, sob pena de se excluir aqueles empregados que, mesmo possuindo maior patrimônio que seu empregador, lhe vende sua força de trabalho.

Certo é que, como verificado no Capítulo 1 do presente trabalho, a maioria das empresas componentes da rede de empresas, quando submetidas à entrega de produtos, depende economicamente da empresa principal ou então de grandes conglomerados, o que, no presente caso, é um forte indício da existência da descentralização da produção com vistas à redução da mão de obra e de seus custos.

Entretanto, certo é que a dependência que se estuda no presente item é a dependência sob o aspecto jurídico, convencionada como subordinação.

A subordinação levará em consideração a submissão do trabalhador não à figura de seu patrão, mas, como adverte o Prof. Souto Maior, à relação de poder derivada da atividade exercida ${ }^{143}{ }^{144}$, sob pena de se admitir a coisificação do trabalhador mediante sua sujeição pessoal às ordens pessoais do empregador personificado.

Afirma o Prof. Süssekind, que a subordinação é jurídica porque "resulta de um contrato: nele encontra seu fundamento e seus limites. (...) Há de se partir do pressuposto da liberdade individual e da dignidade da pessoa do trabalhador (...). A subordinação não cria um status subjectionis: é apenas uma situação jurídica. ${ }^{145,}$

Apenas para ilustrar pequena crítica a esta teoria, sem adentrar nos meandros do contratualismo e do anticontratualismo, em 1905, Evaristo de Moraes, de acordo com as bases teóricas construídas em Karl Marx e Herbert Spencer, afirmava que essa liberdade era "pouca coisa, na prática: pois, mudando de oficina, o operário apenas troca uma escravidão por outra. O constrangimento que a vida industrial moderna exerce

\footnotetext{
${ }^{143}$ MAIOR, Jorge Luiz Souto. Relação de emprego e direito do trabalho, São Paulo: LTr, 2008, p. 62. ${ }^{144}$ Ou ainda, como coloca Paulo Emílio Ribeiro de Vilhena, a "participação integrativa da atividade do trabalhador na atividade do credor do trabalho". Relação de emprego: estrutura legal e supostos. São Paulo: LTr, 1999, pp. 463-64.

${ }^{145}$ SÜSSEKIND, Arnaldo Lopes et alii, Instituições..., p. 249.
} 
sobre o operário parece ao grande filósofo e sociólogo inglês mais duro do que o do senhor em relação ao escravo."146

Guardadas as devidas proporções quanto à evolução da legislação protetiva, no que tange à verdadeira liberdade o conceito ainda hoje é válido; oprimido por sua situação de desprovimento patrimonial próprio que lhe possa garantir o sustento, o trabalhador é obrigado a vender sua força de trabalho. Portanto, a liberdade atinente ao trabalhador restringe-se apenas e tão somente à procura do emprego, muitas vezes tendo de se sujeitar àquele que o aceita, e não o que melhor lhe cabe de acordo com o que precisa ou deseja.

Trocando em miúdos, no que tange ao conceito clássico de subordinação, temse que "ao direito do empregador de dirigir e comandar a atuação concreta do empregado corresponde o dever de obediência, diligência e fidelidade do empregado" 147 .

Ocorre, entretanto, que este conceito abarca somente a relação dicotômica, dual, entre o empregador (empresa) e a pessoa natural que é diretamente contratada, tem sua CTPS anotada e desempenha suas funções dentro da estrutura daquela empresa mediante ordens diretas.

A situação que ora se vislumbra não está comportada por este conceito simplista, merecendo necessária releitura.

Neste sentido, interessante destacar as palavras do Prof. Souto Maior ${ }^{148}$, mais uma vez, mas que elucidam com perfeição o que ora se pretende:

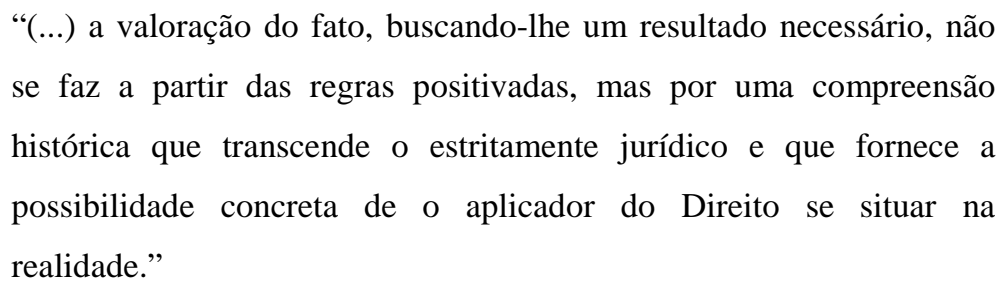

${ }^{146}$ MORAES FILHO, Evaristo de. Apontamentos..., p. 11.

${ }_{148}^{147}$ SÜSSEKIND, Arnaldo Lopes et alii, Instituições..., p. 250.

${ }^{148}$ MAIOR, Jorge Luiz Souto. Curso de direito do trabalho - Vol. I, Parte I, São Paulo: LTr, 2011, p. 630-631. 
E assim que se construiu a teoria da subordinação estrutural, desenvolvida pelo Ministro Maurício Godinho Delgado ${ }^{149}$, igualmente tomado pela preocupação de uma releitura do conceito de subordinação, amplificando-a para admitir a inserção do trabalhador na dinâmica do tomador final de seus serviços, daquele que realmente aufere lucros de sua força de trabalho:

"Estrutural é, pois, a subordinação que se manifesta pela inserção do trabalhador na dinâmica do tomador de seus serviços, independentemente de receber (ou não) suas ordens diretas, mas acolhendo, estruturalmente, sua dinâmica de organização e funcionamento".

Referida tese, vale destacar, é produto do estudo da autora Gabriela Neves Delgado, que entende que quando o caput do art. $7^{\circ}$ da Constituição Federal de 1988 elenca direitos constitucionais trabalhistas, ele o faz para todo e qualquer trabalhador. ${ }^{150}$

Tal teoria, impende destacar, não se consolidou no mundo jurídico por tentar dissolver a dicotomia clássica do trabalhador autônomo versus trabalhador empregado, o que empreenderia toda uma revisão da construção do ordenamento jurídico trabalhista.

Contudo, não é demais estabelecer a eficácia desta teoria para abater as tentativas flexibilizadoras do capital, como é a terceirização e sua espécie ora estudada, a subcontratação.

O conceito se estabeleceria a partir de uma perspectiva objetiva da prestação de serviços, não mais na subordinação do empregado às ordens do empregador, mas, como pondera Lorena Vasconcelos Porto, "pela simples integração da prestação laborativa nos fins da empresa. Havendo a inserção dos serviços prestados pelo trabalhador nos objetivos perseguidos pelo tomador, configura-se a subordinação.”151

Desta forma, a força de trabalho empreendida pelo trabalhador empregado da empresa subcontratada, uma vez que se integra aos objetivos empresariais da empresa

\footnotetext{
${ }^{149}$ DELGADO, Maurício Godinho. Direitos fundamentais na relação de trabalho. In: Revista LTR 7006/667 apud MAIOR, Jorge Luiz Souto. Relação de emprego..., p. 62.

${ }^{150}$ Vide: DELGADO, Gabriela Neves. Direito fundamental ao trabalho digno. São Paulo: LTr, 2006.

151 PORTO, Lorena Vasconcelos. A subordinação no contrato de trabalho - uma releitura necessária. São Paulo: LTr, 2009, p. 250.
} 
subcontratante, notadamente por ser-lhe permanente e essencial, seria ele subordinado a esta última e, portanto, seu empregado direto.

Tal teoria se aplicaria em definitivo aos exemplos demonstrados no presente trabalho, como no caso NESTLÉ x OFICINA DO CACAU, HBR x SAFETLINE ou até mesmo nas confecções e indústrias de calçados, desconstituindo a aparência de pessoa jurídica das subcontratadas.

Destaca-se, inclusive, os referidos julgados em que o Ministro foi autor, quando do exercício de seu mister como Desembargador na Corte trabalhista da $3^{\mathrm{a}}$ Região $^{152}$ :

EMENTA: VÍNCULO DE EMPREGO - CONFIGURAÇÃO - A relação empregatícia forma-se quando presentes os elementos fático-jurídicos especificados pelo caput dos artigos $2^{\circ}$ e $3^{\circ}$ da CLT: trabalho prestado por pessoa física a um tomador, com pessoalidade, não-eventualidade, onerosidade e subordinação. A subordinação, elemento cardeal da relação de emprego, pode se manifestar em qualquer das seguintes dimensões: a clássica, por meio da intensidade de ordens do tomador de serviços sobre a pessoa física que os presta; a objetiva, pela correspondência dos serviços deste perseguidos pelo tomador (harmonização do trabalho do obreiro aos fins do empreendimento); a estrutural, mediante a integração do trabalhador à dinâmica organizativa e operacional do tomador de serviços, incorporando e se submetendo à sua cultura corporativa dominante. Atendida qualquer destas dimensões da subordinação, configura-se este elemento individuado pela ordem jurídica trabalhista (art. $3^{\circ}$, caput, CLT). TRT $3^{\text {a }}$ Região (MG). Autos nº 00326-2007-07603-00-4, Rel. Des. Mauricio Godinho Delgado. Reclte: Luciano Maurílio da Silva; Recldas: Aroeira Telecomunicações Ltda; Norte Sul Representaç̃os; Tim Maxitel, Publicação: 31/08/2007.

Muito interessante e elucidativo este outro entendimento, de lavra do mesmo Tribunal, do Desembargador Resende Chaves Junior:

VÍNCULO DE EMPREGO COM A TOMADORA DOS SERVIÇOS. SUBORDINAÇÃO ESTRUTURAL - Em estando o trabalhador inserido na rede da estrutura produtiva da empresa pós-industrial e 
flexível, não há mais necessidade de ordem direta do empregador, que passa a ordenar apenas a produção. Nesse ambiente pós-grande indústria, cabe ao trabalhador ali inserido habitualmente apenas “colaborar". A nova organização do trabalho pelo sistema da acumulação flexível, imprime uma espécie de cooperação competitiva entre os trabalhadores que prescinde do sistema de hierarquia clássica. Em certa medida, desloca-se a concorrência do campo do capital, pra introjetá-la no seio da esfera do trabalho, pois a própria equipe de trabalhadores se encarrega de cobrar, uns dos outros, o aumento da produtividade do grupo; processa-se uma espécie de sub-rogação horizontal do comando empregatício. A subordinação jurídica tradicional foi desenhada para a realidade da produção fordista e taylorista, fortemente hierarquizada e segmentada. Nela prevalecia o binômio ordem-subordinação. Já no sistema ohnista, de gestão flexível, prevalece o binômio colaboração-dependência, mais compatível com uma concepção estruturalista da subordinação. Nesta ordem de idéias, é irrelevante a discussão acerca da ilicitude ou não da terceirização, como também a respeito do disposto no art. 94, II, da Lei $n^{\circ} 9.472 / 97$, já comentada acima, pois no contexto fático em que se examina o presente caso, ressume da prova a subordinação da reclamante-trabalhadora ao empreendimento de telecomunicações, empreendimento esse que tem como beneficiário final do excedente do trabalho humano a companhia telefônica, repete-se. TRT $3^{\text {a }}$ Região (MG). Autos no 00776-2008-010-03-00-6 RO, Rel. Des. José Eduardo Resende Chaves Junior, Reclte: Ellen Campos Câmara; Recldas: SCI Serviços Ltda e Telemar Norte Leste S.A., publicação: 03/04/2009.

Inobstante ambos os julgados referirem-se à prestação de serviços como a modalidade de terceirização, é importante destacar que se trata de um posicionamento de vanguarda, cuja tendência - e escopo desta pesquisadora com o presente trabalho - é ampliar-se também aos casos de produção em rede e contrato de facção.

Analisando a mesma tese empreendida pelo I. Ministro, os magistrados e juristas Marcus Menezes Barberino Mendes e José Eduardo de Resende Chaves Junior ${ }^{153}$ (deste

\footnotetext{
${ }_{152}^{15}$ Ementa extraída da obra supra, p. 250-251.

153 MENDES, Marcus Menezes Barberino \& CHAVES JUNIOR, José Eduardo de Resende. Subordinação estrutural-reticular e alienidade. In: Revista do Tribunal Regional do Trabalho da $15^{\mathrm{a}}$ Região, Campinas, SP, n. 32, jan/jun 2008, p. 127-146.
} 
último, inclusive, que se observa o julgado acima), falam em subordinação estruturalreticular, abordando o caráter da rede de empresas em que se insere o trabalhador.

Inicialmente, a subordinação, ressaltam os autores, estava restrita à esfera subjetiva, formando-se entre padrão e empregado e desenvolvendo-se, num contexto de centralidade produtiva, o local onde se desenvolvia o comando e a prestação do trabalho concentrava-se no interior da fábrica.

Contudo, o avanço da sociedade industrial proporcionou desenvolvimento ao capitalismo de modo a suscitar um avanço tecnológico (notadamente diante do teletrabalho e dos sofisticados meios de comunicação e logística) que igualmente se sucedeu nas tentativas de elisão de sua responsabilidade pelo risco da atividade empreendida.

A partir disso, a legitimação passiva daquele que deve responder pelos encargos trabalhistas e pelo contrato de trabalho se torna diluída; a alienidade, ou seja, a desvinculação do trabalhador da utilidade patrimonial do trabalho (o que efetivamente produz) e o alheamento (para quem é efetivamente produzido determinado bem) acabam por ser determinantes para se desenvolver uma "exegese sistemática e estável $^{154 \text { " }}$ para a constituição da relação de emprego, conceitos não verificados na ideia tradicional de subordinação.

Nesse contexto, poderá se observar, à guisa dos julgados que isentam de qualquer responsabilidade a empresa principal da rede produtiva ou subcontratante do contrato de facção, que há evidente desvirtuamento conceitual da relação de emprego, mormente em razão da "crescente concepção do trabalhador (supostamente) autônomo, mas econômica e habitualmente dependente de uma mesma rede produtiva. ${ }^{155,}$

Aliado a isso, os autores criticam a forma pela qual os juízes estão interpretando os signos contidos na CLT. Reconhecem que embora não seja possível uma interpretação infinita, já que as normas compõem um sistema de comunicação, é certo, contudo, que as possibilidades semânticas do conceito de subordinação jurídica não

\footnotetext{
${ }^{154}$ Idem, p. 135.

155 Idem, p. 136.
} 
estão esgotadas, notadamente do contínuo seccionamento (pulverização) das atividades empresariais.

Nesse sentido, imprescindível, ainda, conceber-se um novo conceito de empregador, como é a figura do consórcio de empregadores:

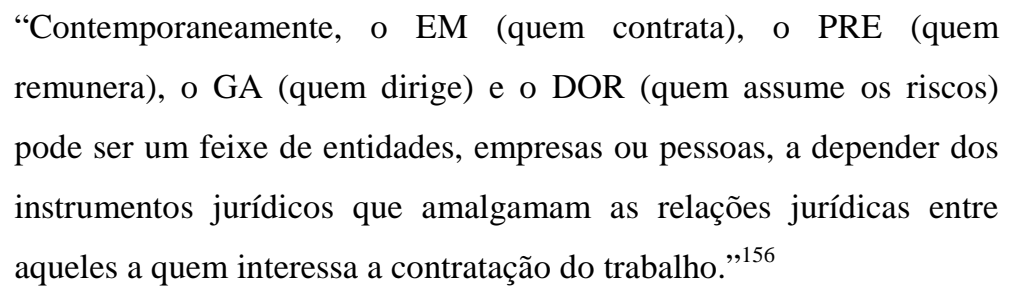

A Súmula 331 do TST admitiu referido seccionamento, assimilando parcialmente a subordinação estrutural-reticular. Coloca, contudo, que para se verificar o vínculo de emprego entre subcontratante e os empregados da empresa subcontratada, deverá verificar-se a existência de dois requisitos - a pessoalidade na prestação do trabalho e a existência de ordens diretas aos trabalhadores.

Este último requisito, entretanto, sob o ponto de vista dos juristas acima, é equivocado, uma vez que a atual realidade produtiva claramente confunde o poder empregatício (gênero) com a ordem direta (espécie). Logo, demais componentes do gênero poder empregatício serão igualmente suficientes para a configuração do vínculo de emprego, verificando-se, com a introdução das técnicas toyotistas de produção, a flexibilização do modelo de produção baseado na "ordem-subordinação" e passando-se para o modelo "colaboração-dependência".

Referido modelo externaliza-se pela falsa liberdade e autonomia conferidas ao trabalhador mediante, por exemplo, a secção da hierarquia ou o Home Office, a criação de comandos abstratos presentes nos regulamentos, treinamentos ou contratos, a execução do trabalho distante da estrutura central do capital, a concessão de vultosa remuneração a trabalhadores de alto escalão ${ }^{157}$ e se serviriam para afastar a incidência da relação de emprego (em especial a subordinação), nomeadamente em se verificando

\footnotetext{
${ }^{156}$ Idem, p. 137.

${ }^{157}$ Admitem, ainda, a subordinação mediante múltiplas outras formas de controle e mando (gestão), como GPS, celulares, tacógrafos, softwares de vigilância e registro, palm tops, câmeras de vídeo, relatórios de produção e desempenho, sejam analógicos ou digitais. Idem, p. 144.
} 
a empresa-rede. Trataria-se, mais do que tudo, da existência de trabalhadores 'autônomo-dependentes'.

Contudo, para os autores:

\begin{abstract}
"A subordinação neste contexto subsiste, ainda que difusa, latente e diferida, justificando, dessa forma, a extensão a eles dos direitos celetistas. O trabalhador supostamente autônomo, mas habitualmente inserido na atividade produtiva alheia, a despeito de ter controle relativo sobre o próprio trabalho, não detém nenhum controle sobre a atividade econômica." 158
\end{abstract}

E, desta forma:

“(...) a subordinação jurídica emerge não apenas do uso da voz do empregador, do supervisor ou do capataz. Ela pode se formar na retina dos múltiplos agentes econômicos coordenados pela unidade central, de modo silencioso e aparentemente incolor e até indolor. A subordinação jurídica pode ser então 'reticular', também nesse sentido e através de instrumentos jurídicos de associação empresária, onde nenhuma atividade econômica especializada é desenvolvida pelo suposto empregador, que se envolve na produção de um determinado resultado pactuado com a unidade central. Suposto, não porque em verdade não o seja, mas por não ser o único empregador."159

Destaca-se, portanto, que na rede empresarial, haverá o resultado do vínculo de emprego decretado diretamente com a empresa principal subcontratante (seja de trabalhadores supostamente autônomos ou aqueles cujo contrato de trabalho foi estabelecido junto à subcontratada) e, em se tratando de situações em que outras estão envolvidas, em uma verdadeira cadeia de desenvolvimento de um produto, serão as demais solidariamente responsáveis, nos termos do $\S 2^{\circ}$, do art. $2^{\circ}$, da CLT.

Desta forma, imputando a todos os componentes da rede econômica (reticular, portanto), não se verificaria a necessidade de se perquirir a existência de fraude, de terceirização de atividade-fim ou da mera intermediação de mão de obra, consoante aponta a Súmula 331, do TST, uma vez que, conforme concluem, "o mais relevante é

\footnotetext{
158 Idem, p. 141.

${ }^{159}$ Idem, p. 143.
} 
assegurar a efetividade do direito material do trabalho e não a imputação da fraude, afinal inexistente se todos são empregadores." 160

Assumir a existência desse grupo independe, como se vem ressaltando, a existência de uma coalizão formal de referido grupo, bastando que os fatos demonstrem a existência de um objetivo comum no mercado mediante a inserção de produtos e serviços produzidos/fornecidos em conjunto.

Interessante, neste sentido, observar também as decisões abaixo:

\section{VÍNCULO DE EMPREGO - SUBORDINAÇÃO - TRABALHO EXECUTADO NO DOMICÍLIO.}

Se no exercício das funções, o trabalhador executa tarefas inseridas no contexto das atividades essenciais ao processo produtivo da empresa, não se exige, para análise do elemento subordinação, prova de expedição de ordens e fiscalização direta, bastando que se passe a ordenar a produção, o que traduz numa forma de organização produtiva.

O fato de o serviço ser prestado na casa do trabalhador não exclui a relação de emprego, pois não há distinção entre o trabalho realizado no estabelecimento do empregador e o executado no domicílio do empregado (Artigo $6^{\circ}$, da CLT).

O trabalhador em domicílio integra, embora à distância, a organização empresarial sob comando do titular desta, que assume, na realidade prática, todo o risco do negócio. Não se trata de trabalho por conta própria, mas por conta alheia, estando evidente, a subordinação jurídica, principal elemento caracterizador da relação de emprego, bem como a onerosidade, a pessoalidade e a não eventualidade do serviço prestado. TRT 15 ${ }^{\mathrm{a}}$ Região (Campinas, SP), autos no 000034008.2011.5.15.0133, Reclte: Talita Viana Alves; Recldas: Rodrismar Porto Morais, Plant Forte Comércio de Produtos Agrícolas Ltda., Rel. Des. Dagoberto Nishina de Azevedo, publicação: 16/07/2012.

VÍNCULO EMPREGATÍCIO. SUBORDINAÇÃO RETICULAR. CONFIGURAÇÃO

Dá-se a chamada subordinação reticular quando, não obstante o laborista tenha um controle relativo sobre suas funções, de forma supostamente autônoma, não detém a mesma autonomia com relação

${ }^{160}$ Idem, ibidem. 
ao aspecto econômico da atividade empresarial. Na dúvida entre o trabalho dito "autônomo-dependente" e o empregado clássico, a boa regra de hermenêutica aconselha a não reduzir o potencial expansivo e protetivo do direito do trabalho.

Nestas condições, com a existência simultânea dos demais elementos caracterizadores da relação de emprego, a saber; onerosidade, pessoalidade e habitualidade, deve-se reconhecer o vínculo empregatício, com a conseqüente descaracterização de outras formas de relação de trabalho. Recurso da ré a que se nega provimento. TRT 15ª Região (Campinas, SP), autos no 00901-2007-007-15-00-9, Reclte: Deuber Gustavo Rodolfo; Recldas: Célia Maria Gardiano Barbin, Henrique Barbin Neto, Rel. Des. Carlos Roberto do Amaral Barros, publicação: 04/06/2010.

Interessante a ementa abaixo que também nos fornece ótima lição sobre subordinação:

SUBORDINAÇÃO ESTRUTURAL, INTEGRATIVA OU RETICULAR - OU SIMPLESMENTE SUBORDINAÇÃO. CARACTERIZAÇÃO. A subordinação como um dos elementos fático-jurídicos da relação empregatícia é, simultaneamente, um estado e uma relação. Subordinação é a sujeição, é a dependência que alguém se encontra frente a outrem. Estar subordinado é dizer que uma pessoa física se encontra sob ordens, que podem ser explícitas ou implícitas, rígidas ou maleáveis, constantes ou esporádicas, em ato ou em potência. Na sociedade pós-moderna, vale dizer, na sociedade info-info (expressão do grande Chiarelli), baseada na informação e nainformática, a subordinação não é mais a mesma de tempos atrás. Do plano subjetivo - corpo a corpo ou boca/ouvido- típica do taylorismo/fordismo, ela passou para a esfera objetiva, projetada e derramada sobre o núcleo empresarial. A empresa moderna livrou-se da sua represa; nem tanto das suas presas. Mudaram-se os métodos, não a sujeição, que trespassa o próprio trabalho, nem tanto no seu modo de fazer, mas no seu resultado. O controle deixou de ser realizado diretamente por ela ou por prepostos. Passou a ser exercido pelas suas sombras; pelas suas sobras - em células de produção. A subordinação objetiva aproxima-se muito da não eventualidade: não importa a expressão temporal nem a exteriorização dos comandos. No fundo e em essência, o que vale mesmo é a inserção objetiva do 
trabalhador no núcleo, no foco, na essência da atividade empresarial. Nesse aspecto, diria até que para a identificação da subordinação se agregou uma novidade: núcleo produtivo, isto é, atividade matricial da empresa, que Godinho denominou de subordinação estrutural. A empresa moderna, por assim dizer, se subdivide em atividades centrais e periféricas. Nisso ela copia a própria sociedade pós-moderna, de quem é, simultaneamente, mãe e filha. Nesta virada de século, tudo tem um núcleo e uma periferia: cidadãos que estão no núcleo e que estão na periferia. Cidadãos incluídos e excluídos. Trabalhadores contratados diretamente e terceirizados. Sob essa ótica de inserção objetiva, que se me afigura alargante (não alarmante), eis que amplia o conceito clássico da subordinação, o alimpamento dos pressupostos do contrato de emprego torna fácil a identificação do tipo justrabalhista. Com ou sem as marcas, as marchas e as manchas do comando tradicional, os trabalhadores inseridos na estrutura nuclear de produção são empregados. Na zona grise, em meio ao fogo jurídico, que cerca os casos limítrofes, esse critério permite uma interpretação teleológica desaguadora na configuração do vínculo empregatício. Entendimento contrário,data venia, permite que a empresa deixe de atender a sua função social, passando, em algumas situações, a ser uma empresa fantasma - atinge seus objetivos sem empregados. Da mesma forma que o tempo não apaga as características da não eventualidade; a ausência de comandos não esconde a dependência, ou, se se quiser, a subordinação, que, modernamente, face à empresa dependência econômica. TRT $3^{\text {a }}$ Região (MG). Autos no 00942-200803-00-2 RO, Reclte: Arlete Maria de Souza; Recldas: TNL CONTAX S/A, TELEMAR NORTE LESTE S/A, Rel. Des. Luiz Otávio Linhares Renault, publicação: 13/12/2008.

Em recente julgado, entendeu o C. TST com relação a uma grande indústria do ramo da siderurgia pela isonomia de direitos entre empregados de seu quadro e de empresas subcontratadas, observando-se, para tanto, a existência da aludida subordinação estrutural. Destaca-se trecho que interessa ao presente estudo: 


\section{LABORAL}

$O$ sindicato-Autor propôs a presente ação, alegando que os substituídos fazem jus à Participação nos Lucros e multa convencional asseguradas por instrumento normativo firmado entre o Sindicato das Indústrias Metalúrgicas, Mecânicas e de Material Elétrico e Eletrônico de João Monlevade, Barão de Cocais, Bela Vista de Minas, São Domingos do Prata e entre o Sindicato dos Trabalhadores das Indústrias Metalúrgicas, Mecânicas, Material Elétrico e Eletrônico de João Monlevade, São Domingos do Prata, Bela Vista de Minas e Rio Piracicaba.

Assevera que os substituídos prestam serviços dentro da usina do Grupo Arcellor Mittal S.A., juntamente com os empregados da tomadora, em regime de conexão funcional, nas mesmas condições e ambiente de trabalho, devendo ser reconhecido tratamento isonômico, aplicando-se, por analogia, o art. 12 da Lei 6.019/74.

A Ré, por sua vez, apresentou defesa, alegando que seu objetivo social consiste na locação de máquinas e equipamentos (montagem e desmontagem de andaimes), estando seus empregados afetos aos instrumentos normativos firmados entre a Federação do Comércio do Estado de Minas Gerais e a Federação dos Empregados no Comércio e Congêneres do Estado de Minas Gerais, para quem são recolhidas as contribuições sindicais.

Integral razão assiste ao Recorrente.

Com efeito, a regra geral é que o enquadramento sindical do empregado seja determinado pela atividade preponderante da empresa, pois a cada categoria profissional de empregados corresponde uma atividade econômica do empregador.

Assim, a categoria profissional do empregado é a que se adequa à atividade preponderante da empresa em que ele trabalha.

Dessa forma, todos os empregadores, empregados, agentes ou trabalhadores autônomos, ou profissionais liberais podem associar-se livremente, desde que exerçam, respectivamente, a mesma atividade ou profissão, similares ou conexas.

Por conseguinte, a viga mestra do sindicalismo brasileiro é a categoria, que pode ser diferenciada e se forma por empregados que exerçam profissões ou funções diferenciadas por força de estatuto profissional especial ou em conseqüência de condições de vida singulares. 
No vértice de uma e de outra figura depara-se com o mesmo ponto de envergadura jurídica: a categoria, cuja aglutinação se dá pela identidade de atividades e de vida. O enquadramento sindical do empregado é determinado em estrito paralelismo com a atividade preponderante da empresa.

Parte-se da atividade preponderante da empresa para chegarse à categoria profissional, sendo que o caminho inverso, na maioria das vezes, leva ao mesmo resultado, porque poucas são as categorias diferenciadas e o foco predominante na empresa acaba por dominar e arrastar a maioria das atividades desenvolvidas por seus empregados. A economia moderna, marcada pela fusão de empresas e pela diversidade de atividades, tem conduzido as empresas à exploração de diversas atividades, com linhas tênues quanto à efetiva predominância de uma sobre a outra.

E no vertente caso em exame, verifica-se que as atividades preponderantes da empresa demandada, empregadora dos substituídos no presente feito, não se limitam e nem estão afetas, isoladamente, à locação de máquinas e equipamentos (andaimes), como aparentemente consta do contrato social, cláusula $1^{a}$., folha 86, mas, sim, igualmente, à montagem e desmontagem dos mesmos, através de pessoas qualificadas para tanto.

Assim com tranqüilidade se afirma até mesmo em face do argumento tão reiterado - e desconsiderado na origem, venia concessa - pelo Sindicato recorrente, a respeito da manutenção, por mais de cinco anos, de contrato com a empresa Arcellor Mittal S.A., através do qual a recorrida fornece a mão-de-obra especializada à execução do mister; aliás, trabalhadores esses terceirizados que laboram na função, justamente, de montadores e ajudantes de andaimes e por anos a fio, sem que a eles se estendam os mesmos direitos e benesses garantidos aos demais empregados da tomadora.

Não dá azo à dúvida, a propósito, o documento que a própria empresa ré acosta ao processado, folhas 108/117 e que, supostamente, referendaria a tese defensiva. Entrementes, lá se infere que o objeto da contratação da Escalar pelo Grupo Arcellor (pertencente, frise- se, à Companhia Siderúrgica Belgo-Mineira), é a locação, montagem, remanejamento e desmontagem de andaimes tubulares, atividade cuja execução seria impossível sem a disponibilização de mão-de-obra especializada para tanto. Interessante ainda pontuar a relação iniciada em julho de 2004, teoricamente para atender à necessidade emergencial que se 
desnatura (é flagrante), quando observamos os aditivos pactuados seqüencialmente no curso de todo aquele ano, com extensão ao de 2005 e 2006, culminando com o 10 . Termo Aditivo datado de 20 de dezembro de 2006, sem prazo previsto para o término. Tenho por suficiente a circunstância para demonstrar, à saciedade, o quão imprescindível é a atividade empreendida pelos substituídos ao alcance dos objetivos econômicos da tomadora da mão-de-obra, o que poderia nos levar até a uma ilicitude da terceirização, frise-se.

Nessa linha de raciocínio, a força de trabalho disponibilizada pela recorrida estava, também, jungida à subordinação 'estrutural' ou 'integrativa' - como a denomina Bruno Alves Rodrigues (RODRIGUES, Bruno Alves Novo paradigma de subordinação na relação de emprego, in Rev. Trib. Reg. Trab. $3^{a}$ Reg., Belo Horizonte, v.39, n.69, jan./jun.2004, pp. 72-73.) - ou ainda, como preferimos, subordinação 'reticular'.

Aliás, no magistério do insigne Prof. Maurício Godinho Delgado, a subordinação estrutural é 'a que se manifesta pela inserção do trabalhador na dinâmica do tomador de seus serviços, independentemente de receber (ou não) suas ordens diretas, mas acolhendo, estruturalmente, sua dinâmica de organização $e$ funcionamento' (DELGADO, Maurício J. Godinho - Direitos fundamentais na relação de trabalho in SILVA, Alessandro etti alli coordenadores Direitos humanos: essência do direito do trabalho São Paulo: LTr, 2007, p. 86).

E segue o eminente Professor precisando esse novo conceito de relação de emprego, sublinhando que a 'subordinação estrutural supera as dificuldades de enquadramento de situações fáticas que o conceito clássico de subordinação tem demonstrado, dificuldades que se exacerbam em face, especialmente, do fenômeno contemporâneo da terceirização trabalhista. Nesta medida ela viabiliza não apenas alargar o campo da incidência do Direito do Trabalho, como também conferir resposta normativa eficaz a alguns de seus mais recentes instrumentos desestabilizadores - em especial a terceirização'.

$\mathrm{Na}$ função de montadores de andaimes e ajudantes, os substituídos exerciam mister essencialmente inserido nas atividades empresariais da empresa contratada pela reclamada. E uma vez. inseridos neste contexto essencial da atividade produtiva da empresa pós-industrial e flexível, não há mais necessidade de ordem direta do empregador, que passa a ordenar apenas a produção. 
Neste ambiente pós-grande indústria, cabe ao trabalhador ali inserido habitualmente apenas 'colaborar'. A nova organização do trabalho, pelo sistema da acumulação flexível, imprime uma espécie de cooperação competitiva entre os trabalhadores que prescinde do sistema de hierarquia clássica. Em certa medida, desloca-se a concorrência do campo do capital, para introjetá-la no seio da esfera do trabalho, pois a própria equipe de trabalhadores se encarrega de cobrar, uns dos outros, o aumento da produtividade do grupo; processa-se uma espécie de sub-rogação horizontal do comando empregatício.

A subordinação jurídica tradicional foi desenhada para a realidade da produção fordista e taylorista, fortemente hierarquizada e segmentada. Nela prevalecia o binômio ordem-subordinação. Já no sistema ohnista, de gestão flexível, prevalece o binômio colaboraçãodependência, mais compatível com uma concepção estruturalista da subordinação.

A nova organização produtiva concebeu a empresa-rede que se irradia por meio de um processo aparentemente paradoxal, de expansão e fragmentação, que, por seu turno, tem necessidade de desenvolver uma nova forma correlata de subordinação reticular.

Nessa ordem de idéias, é irrelevante a discussão acerca da ilicitude ou não da terceirização (que de toda sorte não integra a litiscontestatio, não se olvida), pois no contexto fático em que se examina o presente caso, ressuma da prova a subordinação dos trabalhadores ao empreendimento do tomador, esse que figura como beneficiário final do excedente do trabalho humano disponibilizado pela ré.

O poder de organização dos fatores da produção é, sobretudo, poder, e inclusive poder empregatício de ordenação do fatortrabalho. E a todo poder corresponde uma antítese necessária de subordinação, já que não existe poder, enquanto tal, sem uma contrapartida de sujeição. Daí que é decorrência lógica concluir que o poder empregatício da empresa subsiste, ainda que aparentemente obstado pela interposição de empresa prestadora de serviço. $O$ primado da realidade produtiva contemporânea impõe reconhecer a latência e o diferimento da subordinação direta.

Conclui-se, nesse viés, que independentemente da licitude ou não da terceirização de serviços e dispensada, inclusive, eventual prova da subordinação direta do trabalhador ao tomador, fruto da inserção daquele na organização produtiva da empresa-rede, é a 
extensão dos direitos e vantagens garantidos aos empregados daquela que se beneficia da mão-de-obra, também àqueles que, via interposta pessoa, contribuem para o alcance dos seus objetivos econômicos.

Destarte, ao reverso da compreensão originária e na linha de argumentação recursal, inteiramente aplicáveis são as Convenções Coletivas trazidas com a inicial, seja porque o objetivo social da Ré corresponde à categoria profissional representada pelo sindicatoAutor, seja porque as atividades desenvolvidas pelos substituídos contribuem para o atendimento dos interesses finais da tomadora da força de trabalho.

E além do exposto, a pretensão encontra igual suporte tanto no princípio isonômico garantido constitucionalmente, quanto na incidência analógica do artigo 12, da Lei 6.019/74.

Por outro lado, o fato de a Recorrida ter assegurado a seus empregados a participação nos lucros prevista em norma coletiva firmada pelo sindicato-autor, em 2005, se apresenta como um derradeiro reforço ao acolhimento do desiderato.

Provejo, condenando a reclamada ao pagamento da parcela Participação nos Lucros e Resultados - PLR - aos empregados da ré que prestam serviços à empresa Mittal, acrescida da multa convencional vindicada na peça de ingresso por descumprimento da obrigação estabelecida através de negociação coletiva, mero corolário da obrigação determinada. (...) AIRR - 1124084.2008.5.03.0102, Agravado: SINDICATO DOS TRABALHADORES NAS INDÚSTRIAS METALÚRGICAS, MECÂNICAS E DE MATERIAL ELÉTRICO, MATERIAL ELETRÔNICO, DESENHOS, PROJETOS E INFORMÁTICA DE JOÃO MONLEVADE, RIO PIRACICABA, BELA VISTA DE MINAS E SÃO DOMINGOS DO PRATA.; Agravante: ESCALAR EQUIPAMENTOS LTDA. Relator Ministro: Guilherme Augusto Caputo Bastos, Data de Julgamento: 31/10/2012, $2^{\text {a }}$ Turma, Data de Publicação: 16/11/2012.

Observa-se, de acordo com os entendimentos apresentados, que a teoria em questão, embora de vanguarda, já alcança as vertentes do Tribunal Superior, cabendo aos juízes de primeira instância e desembargadores dos tribunais encararem os fatos sob uma perspectiva progressista, de preservação dos direitos trabalhistas e, principalmente, de contenção do avanço desmedido da força do capital sobre o trabalho. 
Trata-se da preservação de direitos sociais fundamentais, constitucionalmente garantidos, cujo ferimento contumaz e reiterado vem causando nada menos do que a precarização das condições de trabalho, o já versado "dumping" social e o desmantelamento completo da proteção do Estado, como se verificou na indústria de calçados em Franca, das confecções em São Paulo, da indústria metalmecânica, etc.

\subsubsection{Projetos de Lei}

O cenário brasileiro da terceirização - nessa, compreendida a subcontratação como estudada - é precário no que tange à situação parlamentar dos projetos de lei em trâmite.

Como visto, a responsabilidade do adquirente de matéria prima trabalhada ou de peças prontas, é dizer, do subcontratante é, na maioria dos casos, limitada à responsabilidade subsidiária proveniente da interpretação que o Tribunal Superior do Trabalho, ao longo dos anos, desde o advento da Lei $n^{\circ} 6.019 / 74$, foi the conferindo diante dos casos práticos.

Diante de um contexto como o nosso, diversos projetos de lei estão em tramitação no Congresso Nacional. Uma vez que a discussão é farta, escolhemos aqueles que mais se destacaram nas pesquisas realizadas sobre o tema.

O Projeto de Lei $n^{\circ}$ 4.302/98 (ANEXO 5), de autoria do ex-Presidente da República Fernando Henrique Cardoso visa regulamentar a prestação de serviços, e dispõe que a empresa contratante é subsidiariamente responsável (art. 21) pelas obrigações trabalhistas e previdenciárias assumidas e inadimplidas pela prestadora de serviços. Tal responsabilidade excepcionalmente se verificará como solidária, entretanto, se demonstrada a existência de grupo econômico entre empresa contratante e contratada. 
O referido Projeto encontra-se desde 04 de julho de 2011 na Mesa Diretora da Câmara dos Deputados ${ }^{161}$. Aprovado na referida Casa, o Projeto Seguirá para tramitação no Senado Federal ${ }^{162}$.

O Projeto de Lei $n^{\circ}$ 4.330/2004 (ANEXO 6), de autoria do Deputado Federal Sandro Mabel (PL-GO) incorpora os dispositivos do Projeto de Lei de autoria do Poder Executivo, que, após mais de 6 anos de "frutíferas discussões", se possibilitou uma tratativa de regulamentação de acordo com a necessidade do mercado.

Neste sentido, o projeto em tese, que mais uma vez somente se refere à prestação de serviços, traz em seu bojo a definição da empresa prestadora de serviços como sendo aquela que presta serviços determinados e específicos para a empresa contratante. É a empresa prestadora responsável pela contratação, remuneração e direção do trabalho de seus empregados, não se formando vínculo de emprego em nenhuma hipótese com a empresa tomadora de serviços.

Referido projeto inova, estabelecendo requisitos formais e financeiros para a constituição da empresa terceirizada (art. $3^{\circ}$ ), como um patamar mínimo patrimonial e, dentre outros, a imobilização de seu capital mediante convenção ou acordo coletivo, a fim de garantir o saldamento das verbas trabalhistas devidas. Contudo, será a empresa contratante a responsável pelas condições ambientais e de segurança dos trabalhadores terceirizados.

Como regra, no que tange à responsabilidade do tomador de serviços, prevê-se a subsidiariedade (art. 10), ficando-lhe ressalvado o direito de ação de regresso em face da prestadora de serviços inadimplente.

Verificando-se a contratação, pela empresa terceirizada de outra empresa (quarteirização) para a prestação de serviços, entre estas se configurará a responsabilidade solidária ante os créditos provenientes da relação de emprego (art. 11).

\footnotetext{
161 Conforme consulta realizada no sítio da Câmara dos Deputados na internet, disponível em http://www.camara.gov.br/proposicoesWeb/fichadetramitacao?idProposicao=20794, acesso em 26/12/2012.

162 Conforme consulta realizada no sítio da Câmara dos Deputados na internet, disponível em http://www.camara.gov.br/proposicoesWeb/fichadetramitacao?idProposicao=267841, acesso em 26/12/2012.
} 
Tal Projeto encontra-se hoje na Comissão de Trabalho, de Administração e Serviço Público da Câmara dos Deputados, desde 08/06/2011.

Conforme se depreende de sua análise, ainda que perfunctória, os Projetos em voga trazem em seu bojo o ideário neoliberal toyotista, privilegiando a manutenção da precarização da relação de trabalho empreendida pela terceirização.

De forma diametralmente oposta, o Projeto de Lei $n^{\circ}$ 1.621/2007 (ANEXO 7), de autoria do Deputado Federal Vicentinho (PT-SP), aborda o assunto com base nos casos vivenciados a partir das experiências sindicais, consolidados pela CUT como forma de demonstração da realidade precária dos trabalhadores terceirizados ao Congresso Nacional.

Referida proposição legal aborda, em sua justificativa, que a terceirização caminha também para as atividades nucleares da empresa, é dizer, no contexto que se aborda, a descentralização produtiva e a externalização industrial.

Em seu texto, contudo, nota-se o estudo da prestação de serviços (art. $2^{\circ}$ ), muito embora aborde a terceirização da atividade fim $\left(\S 1^{\circ}\right.$, art. $\left.3^{\circ}\right)$, definindo-a como o conjunto de operações, diretas ou indiretas, que guardam estreita relação com a finalidade central em torno da qual a empresa foi constituída, está estruturada e se organiza.

Neste comento, proíbe a terceirização ou a contratação de pessoa jurídica para a realização da atividade fim, embora nos pareça que o conceito atribuído a esta continue sendo subjetivo e, portanto, não esclarecedor para fins de aplicação da própria lei.

Pode-se dizer, entretanto, que se trata do primeiro projeto que aborda, ainda que implicitamente, a externalização da produção, permitindo-se a realização dos serviços contratados nas instalações físicas do prestador, desde que se garanta ao trabalhador demovido igualdade de salários, jornada, benefícios, ritmo de produção e condições de saúde e segurança $\left(\operatorname{art.} 7^{\circ}\right)$.

Por sua vez, a responsabilidade do contratante será, independentemente de culpa (in eligendo, ou seja, na escolha da empresa contratada) solidária para com as 
obrigações trabalhistas e previdenciárias assumidas pela empresa contratada perante seus empregados (art. $9^{\circ}$ ).

Ainda, como modo de fomentar a regularização do trabalho terceirizado e reprimir condutas de precarização, dispõe o projeto que será imposta à empresa descumpridora dos termos da Lei multa de $10 \%$ sobre o valor do contrato de terceirização em favor do trabalhador prejudicado, desde que este ingresse com a competente reclamação trabalhista perante o Poder Judiciário.

A proposição, que possui o trâmite mais atualizado, encontra-se hoje na Comissão de Desenvolvimento Econômico, Indústria e Comércio, desde 28/11/2012 ${ }^{163}$. Após tramitação nesta Casa, assim como os demais projetos, seguirá para o Senado Federal para votação.

Por fim, apensado a este último, está o Projeto de Lei nº 6.832/2010 (ANEXO 8), apresentado pelo Deputado Paulo Delgado (PT-MG), complementando-o ao estabelecer à empresa contratante condições para a aplicação da responsabilidade subsidiária frente aos créditos trabalhistas - somente poderá valer-se do aludido benefício de ordem se houver o cumprimento do quanto disposto pelos arts. $2^{\circ}, 3^{\circ}$ e $7^{\circ}$ da referida proposição, ou seja, se a empresa contratante exigir da contratada a apresentação de documentos que demonstrem sua regularidade formal perante os órgãos de registro e fazendários, bem como aqueles que atestem o adimplemento das obrigações trabalhistas.

Desta forma, demonstrando o cumprimento do seu dever de vigilância sobre o empregador formal dos trabalhadores, isentar-se-á da responsabilidade solidária que o Projeto estabelece como regra.

\footnotetext{
163 Conforme consulta realizada no sítio da Câmara dos Deputados na internet, disponível em http://www.camara.gov.br/proposicoesWeb/fichadetramitacao?idProposicao=359983, acesso em 26/12/2012.
} 
Referido projeto encontra-se também na Mesa Diretora da Câmara dos Deputados, desde 17/02/2011, após pedido de desarquivamento para apenso ao Projeto $\mathrm{n}^{\mathrm{o}} 1.621 / 2007^{164}$.

Da análise empreendida dos projetos de lei acima apresentados, verifica-se a existência de embates diametralmente opostos sobre a matéria versada; os dois projetos iniciais, de cunho eminentemente neoliberal, defendem a institucionalização da terceirização nos exatos termos em que hoje se encontra.

No outro ponto, por sua vez, nota-se a intenção eminentemente protecionista ao trabalhador, garantindo-lhe, principalmente, a isonomia e a igualdade pretendida pela Constituição da República frente aos trabalhadores efetivos e, ainda, a plena garantia de satisfação de seus créditos eventualmente inadimplidos pela empresa contratada.

\subsection{Direito comparado}

A utilização do direito comparado também como base de estudos ao instituto em análise justifica-se diante da ausência legislativa específica da qual padece o direito do trabalho brasileiro, inobstante os noticiados projetos de lei em trâmite no Congresso Nacional.

Sem realizar qualquer juízo de valor sobre o objeto do direito comparado, mesmo porque tal empreenderia a tomada de um recorte metodológico próprio, nos restringiremos a analisar a legislação de alguns dos países irmãos, cujo traço histórico de colonização e exploração os une. São esses os membros plenos do Mercosul Argentina e Uruguai - e o país associado ao bloco econômico em 1996, Chile. Atentamos, ainda, para o que nos ensina a Espanha, diante da atualíssima legislação sobre o tema.

A presente escolha fundamenta-se no fato de o Brasil guardar com tais países proximidades histórico-social-econômicas, o que nos confere semelhança também quanto aos problemas experimentados por cada uma dessas sociedades.

\footnotetext{
164 Conforme consulta realizada no sítio da Câmara dos Deputados na internet, disponível em http://www.camara.gov.br/proposicoesWeb/fichadetramitacao?idProposicao=466967, acesso em 26/12/2012.
} 
A semelhança dos processos históricos e das situações sócio-econômicas vivenciadas por esses países são notórias e podem ser visualizadas pela análise crítica dos fatos ocorridos desde a colonização, dos que tiveram lugar durante os processos de independência, durante os regimes autoritários, durante a tentativa de implantação de um modelo neoliberal a partir da década de 90 e também pela análise dos demais fatos subsequentes.

A proximidade social-econômica é evidente e se constata não só pela exploração de mão-de-obra, a existência de trabalho escravo, a proximidade da renda per capita, os valores estabelecidos como salário mínimo em cada país, como também pelo fato implícito, mas vital, na constituição do Mercosul e de qualquer bloco econômico: tal formação somente é possível entre países que possuam realidades próximas, bem como objetivos comuns.

Ainda relativamente ao Mercosul, não se pode olvidar sua trajetória e projetos futuros de integração não apenas econômica, mas também social. Neste diapasão, a importância da pesquisa reflete-se ainda no fato de se observar de que forma tais países enfrentam a situação estudada pelo presente trabalho.

Interessante demonstrar, a título ilustrativo e informativo ao leitor apenas, que o art. $8^{\circ}$ da CLT permite-nos utilizar o direito comparado como mecanismo de integração das normas jurídicas, quando estas forem omissas.

Passamos a análise do instituto de acordo com os referidos países.

\subsubsection{Chile}

O Chile prevê como possibilidade de terceirização, ou genericamente a subcontratação, a externalização laboral, correspondente à colocação para fora do âmbito físico da empresa uma parte do processo produtivo de seus bens ou ainda uma atividade de cunho acessório, como os serviços. Forma-se, portanto, uma relação triangular.

Nessa perspectiva, os trabalhadores se vinculam formalmente à empresa prestadora de serviços ou fornecedoras dos bens a que foi cometida, comumente caracterizada como obra certa ou tarefa, independentemente de sua natureza. 
Como bem explana a estudiosa do direito do trabalho Irene Rojas Miño ${ }^{165}$, a relação assim se estabelece:

\begin{abstract}
"La primera empresa es la contratista o subcontratista y la segunda es la empresa principal o usuaria y es esta última la que encarga a la primera una obra o servicio, en base a un precio, plazo y modalidad de ejecución, bajo alguna fórmula contractual. Lo que identifica a la subcontratación laboral, es que la contratista o subcontratista es la que organiza la específica actividad empresarial objeto de la contrata o subcontrata, por lo que dirige la actividad laboral requerida para la realización de la obra o servicio, manteniendo, desde luego, la dirección laboral de dicha obra. Por consiguiente, la relación individual de trabajo se plantea entre el trabajador y la empresa contratista o subcontratista; sin embargo, el provecho de este trabajo beneficia a la empresa principal."
\end{abstract}

Em razão da existência de referida prestação laboral, foi aprovada, em 14 de janeiro de 2007, a Lei $\mathrm{n}^{\mathrm{o}}$ 20.123, (diploma alterador do Código do Trabalho vigente) que "regula o trabalho em regime de subcontratação, o funcionamento de serviços transitórios e o contrato de trabalho de serviços transitórios. Passou a admitir expressamente, ademais, a modalidade de fornecimento de mão de obra, conquanto se preenchessem alguns pré-requisitos para tanto.

O Código do Trabalho chileno, de 1931, já previa em seu art. 64 (ora derrogado), a possibilidade de responsabilização subsidiária do tomador de serviços a respeito das obrigações laborais e da previdência social decorrentes da relação de emprego mantida entre os trabalhadores e a empresa prestadora de serviços/obras.

O instituto passou a ser previsto no art. 183-A, primeira parte:

Es trabajo en régimen de subcontratación, aquél realizado en virtud de un contrato de trabajo por un trabajador para un empleador, denominado contratista o subcontratista, cuando éste, en razón de un acuerdo contractual, se encarga de ejecutar obras o servicios, por su cuenta y riesgo y con trabajadores bajo su dependencia, para una tercera persona natural o jurídica dueña de la obra, empresa o faena,

\footnotetext{
${ }^{165}$ MIÑO, Irene Rojas. Subcontratación laboral, suministro de trabajo y cesión ilegal de trabajadores. Chile: Abeledo Perrot Legal Publishing, 2011, p. 21.
} 
denominada la empresa principal, en la que se desarrollan los servicios o ejecutan las obras contratadas. Con todo, no quedarán sujetos a las normas de este Párrafo las obras o los servicios que se ejecutan o prestan de manera discontinua o esporádica.

Em suma, a Lei $\mathrm{n}^{\circ} 20.123$ estabeleceu uma nova normativa legal sobre a subcontratação laboral, nos seguintes aspectos: definiu seu conceito; estabeleceu o efeito da imputação da relação laboral à empresa principal quando se verifique que esta situação acoberta uma cessão ilegal de trabalhadores. Ademais, definiu um regime de responsabilidade solidária (art. 183-B) que, sob o cumprimento de exigências específicas, passaria a ser subsidiária.

Neste caso, deverá a empresa subcontratante exigir o cumprimento do seu direito de informação para com a empresa subcontratada, bem ainda exercer a faculdade de reter o montante contratual a ser pago, em benefício dos direitos dos trabalhadores:

Art. 183-C. La empresa principal, cuando así lo solicite, tendrá derecho a ser informada por los contratistas sobre el monto y estado de cumplimiento de las obligaciones laborales y previsionales que a éstos correspondan respecto a sus trabajadores, como asimismo de igual tipo de obligaciones que tengan los subcontratistas con sus trabajadores. El mismo derecho tendrán los contratistas respecto de sus subcontratistas.

El monto y estado de cumplimiento de las obligaciones laborales y previsionales a que se refiere el inciso anterior, deberá ser acreditado mediante certificados emitidos por la respectiva Inspección del Trabajo, o bien por medios idóneos que garanticen la veracidad de dicho monto y estado de cumplimiento. El Ministerio del Trabajo y Previsión Social deberá dictar, dentro de un plazo de 90 días, un reglamento que fije el procedimiento, plazo y efectos con que la Inspección del trabajo respectiva emitirá dichos certificados. Asimismo, el reglamento definirá la forma o mecanismos a través de los cuales las entidades o instituciones competentes podrán certificar debidamente, por medios idóneos, el cumplimiento de obligaciones laborales y previsionales de los contratistas respecto de sus trabajadores. 
En el caso que el contratista o subcontratista no acredite oportunamente el cumplimiento íntegro de las obligaciones laborales y previsionales en la forma señalada, la empresa principal podrá retener de las obligaciones que tenga a favor de aquél o aquéllos, el monto de que es responsable en conformidad a este Párrafo. El mismo derecho tendrá el contratista respecto de sus subcontratistas. Si se efectuara dicha retención, quien la haga estará obligado a pagar con ella al trabajador o institución previsional acreedora.

En todo caso, la empresa principal o el contratista, en su caso, podrá pagar por subrogación al trabajador o institución previsional acreedora.

La Dirección del Trabajo deberá poner en conocimiento de la empresa principal, las infracciones a la legislación laboral y previsional que se constaten en las fiscalizaciones que se practiquen a sus contratistas o subcontratistas. Igual obligación tendrá para con los contratistas, respecto de sus subcontratistas.

E então, aplicar-se-á a responsabilidade subsidiária sobre o tomador, empresa principal:

Art. 183-D. Si la empresa principal hiciere efectivo el derecho a ser informada y el derecho de retención a que se refieren los incisos primero y tercero del artículo anterior, responderá subsidiariamente de aquellas obligaciones laborales y previsionales que afecten a los contratistas y subcontratistas en favor de los trabajadores de éstos, incluidas las eventuales indemnizaciones legales que correspondan por el término de la relación laboral. Tal responsabilidad estará limitada al tiempo o período durante el cual el o los trabajadores del contratista o subcontratista prestaron servicios en régimen de subcontratación para el dueño de la obra, empresa o faena. Igual responsabilidad asumirá el contratista respecto de las obligaciones que afecten a sus subcontratistas, a favor de los trabajadores de éstos.

Se aplicará también, lo dispuesto en el inciso precedente, en el caso que, habiendo sido notificada por la Dirección del Trabajo de las infracciones a la legislación laboral y previsional que se constaten en las fiscalizaciones que se practiquen a sus contratistas o subcontratistas, la empresa principal o contratista, según corresponda, 
hiciere efectivo el derecho de retención a que se refiere el inciso tercero del artículo precedente.

Entretanto, previu também a legislação supra a possibilidade de se verificar a "pseudo-contratação", utilizando-se do instituto para encobrir um ilícito contratual, o fornecimento ilegal de mão de obra. Neste caso, a empresa principal é responsabilizada diretamente, inclusive com relação ao vínculo de emprego dos trabalhadores outrora mantido com a empresa subcontratada.

A primeira espécie de cessão ilegal se configura a partir do não cumprimento das exigências essenciais postas pela lei com relação à subcontratação, ou seja, os serviços se realizam sem sujeição aos requisitos do trabalho em regime de subcontratação, assinalados pelo art. 183-A, supra, ou se limitam a intermediar mão de obra para a realização de uma tarefa.

Neste último caso, formalmente se verifica uma contratação entre empresa principal e subcontratada e o acordo de vontades simplesmente traz em seu bojo a cessão de trabalhadores que passam a depender da empresa principal, mantendo a empresa contratada a aparência de empregadora.

\subsubsection{Argentina}

Para o fim de fazer frente às novas estratégias industriais competitivas, aludem os autores argentinos, a exemplo de Eduardo Alvarez, que a indústria iniciou um processo de fragmentação do ciclo produtivo, na busca de um diferencial no mercado, concentrando-se sua produção no que se denominou "competências nucleares", ou seja, o básico de sua atividade, externalizando (terceirizando) as demais atividades, mesmo que não se tratem das eminentemente periféricas.

A fábrica então redimensionou-se - inclusive fisicamente - reduzindo o tamanho de sua infra-estrutura, na parte em que não era identificável com a rentabilidade desejada, até o limite de concentrar-se em sua atividade nuclear, o que, inclusive, refletiu na mão de obra, que passou a ser oferecida no mercado a um preço mais baixo. 
Nesse sentido, de acordo com o autor supracitado, Alain Supiot ${ }^{166}$ foi um dos primeiros em advertir que a subcontratação tal qual se estuda, a produção em rede, ou "subcontratação centrífuga" gera problemas de natureza muito diferente que, todavia, não estão muito bem resolvidos. Ressaltou, ademais, que a externalização de atividades anteriormente realizadas no seio da empresa, sempre descartando hipóteses de fraude, tem consequências evidentes para os trabalhadores envolvidos, que não encontram solução adequada nas normas tradicionais atinentes à responsabilidade patrimonial e aludiu, ainda, ao caráter insuficiente e limitado da proteção com a que se conta em relação ao multifacetado fenômeno.

Esse é um problema que também se encontra em terra brasiliensis, demandando estudos da presente natureza em ordem a corrigir as deficiências legislativas e adequar o direito à realidade presente.

No irmão latino, contudo, verifica-se dispositivo na Lei de Contrato de Trabalho (LCT, $n^{\circ}$ 20.744) acerca da terceirização genérica (art. 30), preceito que se encontra positivado desde os idos de 1976, época em que vigorava intenso regime ditatorial. Tal fato, insta salientar, demanda diversas críticas dos juristas, inclusive no sentido de se conclamar sua reforma, uma vez que não confere ao trabalhador inserido no contexto da descentralização produtiva a adequada proteção.

Eis o texto do referido artigo:

\author{
Art. 30. - Subcontratación y delegación. Solidaridad. \\ Quienes cedan total o parcialmente a otros el establecimiento o \\ explotación habilitado a su nombre, o contraten o subcontraten, \\ cualquiera sea el acto que le dé origen, trabajos o servicios \\ correspondientes a la actividad normal y específica propia del \\ establecimiento, dentro o fuera de su ámbito, deberán exigir a sus
}

\footnotetext{
${ }^{166}$ SUPIOT, Alain. Trabajo y Empleo: Transformaciones del trabajo y futuro del Derecho del Trabajo Europeo, Ed. D. Teoría, 1999, nota 2, p. 25 y ss., apud ALVAREZ, Eduardo. Artículo: Tercerización, descentralización productiva y derecho del trabajo, In: Revista Argentina - Derecho del Trabajo - ISSN 2250-8074 - Año I - no 1 - Mayo 2012, Editorial Ministerio de Justicia y Derechos Humanos de la Nación, p. 8-9, nota de rodapé $\mathrm{n}^{\circ} 11$.
} 
contratistas o subcontratistas el adecuado cumplimiento de las normas relativas al trabajo y los organismos de seguridad social.

Los cedentes, contratistas o subcontratistas deberán exigir ademas a sus cesionarios o subcontratistas el número del Código Unico de Identificación Laboral de cada uno de los trabajadores que presten servicios y la constancia de pago de las remuneraciones, copia firmada de los comprobantes de pago mensuales al sistema de la seguridad social, una cuenta corriente bancaria de la cual sea titular y una cobertura por riesgos del trabajo. Esta responsabilidad del principal de ejercer el control sobre el cumplimiento de las obligaciones que tienen los cesionarios o subcontratistas respecto de cada uno de los trabajadores que presten servicios, no podrá delegarse en terceros y deberá ser exhibido cada uno de los comprobantes y constancias a pedido del trabajador y/o de la autoridad administrativa. El incumplimiento de alguno de los requisitos harán responsable solidariamente al principal por las obligaciones de los cesionarios, contratistas o subcontratistas respecto del personal que ocuparen en la prestación de dichos trabajos o servicios y que fueren emergentes de la relación laboral incluyendo su extinción y de las obligaciones de la seguridad social". Las disposiciones insertas en este artículo resultan aplicables al régimen de solidaridad específico previsto en el artículo 32 de la Ley 22.250. (Párrafo incorporado por art. 17 de la Ley $N^{\circ}$ 25.013 B.O. 24/09/1998) (grifo nosso)

Prevê, portanto, que a empresa principal logrará desvencilhar-se da responsabilidade solidária, em caso de inadimplência da empresa empregadora (prestadora de serviços), ao demonstrar que exigiu desta última documentos que demonstrem o pagamento mensal dos direitos dos trabalhadores, incluindo-se aqueles derivados da extinção de seu contrato de trabalho e da previdência social.

Interessante demonstrar que, em um recorte histórico breve, referido artigo fora editado em sua redação original no ano de 1974, como $\mathrm{n}^{\circ} 32$, prevendo a responsabilidade solidária da empresa tomadora de obras ou serviços de forma indistinta, às atividades principais ou acessórias, bastando o inadimplemento dos direitos trabalhistas.

Após um ano e meio de sua vigência, contudo, o regime militar, por intermédio da Lei $\mathrm{n}^{\mathrm{o}} 21.297$, promoveu sua alteração in pejus, remunerando-o como de $\mathrm{n}^{\mathbf{0}} 30$, 
limitando, ademais, a responsabilidade solidária aos casos em que a empresa principal subcontrate atividades normais e específicas próprias. E o trabalho de "desmonte" do artigo 30 foi retomado em 1998, com a Lei 25.013, que estabeleceu a necessidade de culpa in vigilando para a decretação da responsabilidade solidária do tomador. Nos demais casos, vigorará, pura e simplesmente, sua impunidade, sequer de supletividade podendo então se cogitar. ${ }^{167}$

E, para ilustrar o entendimento restritivo que se dava ao referido artigo (acompanhando, pois sua interpretação literal e principalmente os objetivos econômicos da época), interessante trazer o caso paradigmático conhecido como "Rodríguez, Juan R. c/ Cía Embotelladora Argentina S.A. y otro""168 (ANEXO 9).

Em sentença proferida em 15 de abril de 1993 pela Corte Suprema de Justiça Nacional da Argentina ( $n^{\circ}$ 317/XXIII), entendeu-se que a subcontratação perpetrada pela empresa produtora de refrigerantes Pepsi Cola em seu esquema produtivo não se trata de terceirização e, portanto, está livre da incidência do art. 30 da LCT, tratando-se meramente de estratégia empresarial de negócios.

Referido trabalhador laborou formalmente para a empresa Cía. Embotelladora Argentina S.A., empresa dedicada à fabricação, venda e distribuição de refrigerantes da linha Pepsi na Capital Federal e região da Grande Buenos Aires. A referida Cía. Embotelladora comprava da Pepsi extratos (xaropes), elaborava o produto final, o vendia e distribuía aos consumidores.

Sustentaram os juízes, inclusive da Corte Nacional de Justiça - que mantiveram a sentença - que a empresa Pepsi não elegeu como atividade empresarial a produção do refrigerante, mas apenas do xarope vendido à empregadora do obreiro; esta, por sua vez, se encarregava da produção do refrigerante em si, pelo que eram absolutamente independentes (inobstante constar do contrato social da ré Pepsi que também era seu objeto social a fabricação das referidas bebidas). Entenderam, outrossim, que não restou demonstrada nenhuma vinculação jurídica entre as empresas,

\footnotetext{
${ }^{167}$ CIAMPA, Gustavo. Artículo: Apuntes para una reforma del art. 30. LCT, In: Revista Argentina Derecho del Trabajo - ISSN 2250-8074 - Año I - no 1 - Mayo 2012, Editorial Ministerio de Justicia y Derechos Humanos de la Nación, p. 22-25.

${ }^{168}$ Disponível em http://www.losrecursoshumanos.com/contenidos/4376-rodriguez-juan-r-c-companiaembotelladora-argentina-sa-y-otro.html, acesso em 6 de dezembro de 2012.
} 
de modo que a responsabilização desta última por dívida alheia seria afrontar dispositivos constitucionais que garantem a intangibilidade patrimonial.

De outro modo, "para que nazca aquella solidaridad es menester que una empresa contrate o subcontrate servicios que complementen o completen su actividad normal. Debe existir una unidad técnica de ejecución entre la empresa y su contratista (...). Esta unidad no ha sido probada en el presente caso."

Rechaçou-se, desta forma, o pedido de responsabilidade solidária formulado pelo trabalhador Juan Rodríguez.

Defendem os autores argentinos que hoje, contudo, o pensamento é diverso, consolidando-se uma tendência protetiva tal qual demanda o princípio protetor. A mudança de composição da Corte Suprema em 2003 trouxe também uma mudança de paradigma.

Para o autor Gustavo Ciampa ${ }^{169}$,

\footnotetext{
"En contraposición al criterio de la anterior integración de la CSJN criterio economicista que supeditaba la protección del trabajador a las reglas del mercado - la Corte Suprema de Justicia en su actual composición ha sido enfática en resaltar que el trabajador es sujeto de "preferente tutela constitucional" remarcando reiteradamente que "el hombre no debe ser objeto de mercado alguno, sino señor de todos éstos, los cuales sólo encuentran sentido y validez si tributan a la realización de los derechos de aquél y del bien común. De ahí que no debe ser el mercado el que someta a sus reglas y pretensiones las medidas del hombre ni los contenidos y alcances de los derechos humanos. Por el contrario, es el mercado el que debe adaptarse a los moldes fundamentales que representan la Constitución Nacional y el Derecho Internacional de los Derechos Humanos de jerarquía constitucional, bajo pena de caer en la ilegalidad'."
}

Certo é que a litigiosidade do art. 30 da LCT e que motivou as discussões e a possibilidade de adoção de uma ou de outra ideologia, reside na expressão "actividad normal y específica propia del establecimiento", como causa da solidariedade passiva na terceirização, isso porque a definição do que seja essencial ou inerente à atividade 
produtiva para fim de estabelecer o dever de responsabilidade solidária da empresa principal torna-se deficiente.

Nesse diapasão, o jurista Eduardo Alvarez assim afirma ${ }^{170}$ :

"Resulta indispensable una modificación del ordenamiento, que, manteniendo los deberes de conducta con los que contratan o subcontratan, referidos a la exigencia del cumplimiento de las disposiciones laborales y de seguridad social, permita conceptualizar con claridad el eje de la responsabilidad y elucidar si la actividad que ha sido objeto de externalización resulta o no indispensable y si el objeto de la empresa podría llevarse a cabo si la tarea es asumida. ${ }^{171}$ En este orden de ideas, y tal como lo sugiriera en el "Informe sobre el estado actual del sistema de relaciones laborales en la Argentina", podríamos inspirarnos en la jurisprudencia del Tribunal Supremo Español y establecer que, para que se genere la solidaridad, será preciso concluir que la actividad contratada o subcontratada posee el carácter de "complementaria absolutamente esencial para el desarrollo de la principal" y que lleva a afirmar, para utilizar palabras del mismo órgano jurisdiccional, que "sólo las tareas que corresponden al ciclo productivo de la empresa" proyectan responsabilidad solidaria."

Isso porque qualquer norma laboral deve encontrar fundamento em um sentido único da disciplina e inspirar-se no principio protetor.

Desta feita, em função das modificações que puderam ter tido as relações de trabalho e os novos métodos de produção, é necessário adequar a normativa legal à nova realidade, a fim de que as transformações operadas nos sistemas produtivos não deixem desguarnecidos os trabalhadores alheios a tais decisões empresariais.

Aponta também o autor Gustavo Ciampa ${ }^{172}$ que "debe ser clara la formulación del texto legal en el sentido de que 'en todos los casos' las empresas serán solidariamente responsables", o que, de vez por todas, solucionaria o conflito perpetrado pela redação de caráter economicista do artigo 30 em destaque.

\footnotetext{
${ }^{169}$ CIAMPA, Gustavo. Op. cit. p. 27-28.

${ }^{170}$ ALVAREZ, Eduardo. Artículo: Tercerización..., p. 17.

${ }^{171}$ Nota da autora: No sentido de se garantir a solvência das empresas envolvidas e, assim, a existência efetiva de crédito suficiente a adimplir os direitos trabalhistas decorrentes dessa relação de trabalho.

172 CIAMPA, Gustavo. Artículo: Apuntes para una reforma del art. 30. LCT..., p. 30.
} 
Há autores, contudo, que defendem que a descentralização produtiva, no seu exato sentido de terceirização de uma porção do processo produtivo da empresa, notadamente com o deslocamento externo físico da atividade empresária de um lugar para outro, tem necessariamente como consequência a decretação do vínculo de emprego entre a empresa principal, subcontratante, e os empregados da subcontratada, em se verificando a intenção de se complicar a identificação da pessoa do empregador.

Neste sentido, o art. 26 da LCT argentina assim define o conceito de empregador:

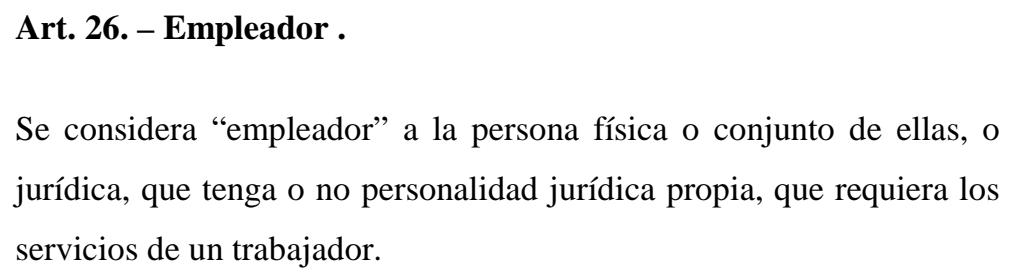

Neste sentido, defende Juan Confalonieri ${ }^{173}$ que, nos últimos anos, a jurisprudência do país tem admitido a figura do empregador plural. Não se trata, contudo, da presença de vários empregadores em uma mesma relação jurídica, ou de várias posições contratuais ocupadas por diferentes pessoas, senão de várias pessoas que ocupam uma mesma única posição.

De acordo com referido autor, tal teoria se baseia no Código Civil argentino (art. 690), notadamente no instituto da obrigação plural ou múltipla, em que concorram elementos como a diversidade de credores, a diversidade de devedores e uma só prestação a ser cumprida, de causa (origem) única. Demanda que cada empregador seja integralmente responsável por cada empregado, e ainda, de forma solidária.

\subsubsection{Uruguai}

O regime jurídico uruguaio se distancia dos demais em seus dispositivos reguladores.

\footnotetext{
${ }^{173}$ CONFALONIERI, Juan A. Artículo: Transformaciones productivas e identificación del empleador. El empleador plural o múltiple, In: Revista Argentina - Derecho del Trabajo - ISSN 2250-8074 - Año I no 1 - Mayo 2012, Editorial Ministerio de Justicia y Derechos Humanos de la Nación, p. 44.
} 
Contudo, em seu conceito aproxima-se de todas as demais definições, inclusive a brasileira. De acordo com Juan Raso Delgue ${ }^{174}$ :

"Desde el punto de vista jurídico, "la subcontratación es un contrato por el cual una empresa se obliga a realizar una o varias obras o servicios en beneficio de un tercero por un precio determinado, asumiendo los riesgos con autonomía técnica y económica.”

No presente caso, são as obras constantes do conceito acima que nos interessa, uma vez que é deste modo que trata o ordenamento jurídico uruguaio a subcontratação proveniente da externalização produtiva.

Tal conceito, contudo, antes da positivação que se analisará, provocou inúmeras discussões doutrinárias, tendo se desenvolvido inúmeras teorias inclusive sobre seu alcance ante os fatos apresentados em juízo ${ }^{175}$.

Inicialmente, a subcontratação teve seu primeiro dispositivo positivado pela Lei $\mathrm{n}^{\circ}$ 10.449, de 1943. Referida lei destacava a necessidade de se trazer ao ordenamento a imposição da regra de um salário mínimo, baseado nas peculiaridades locais dos trabalhadores, e que se servisse para satisfazer às suas necessidades básicas.

Em seu artigo $3^{\circ}$, verifica-se que o legislador dedicou tratamento também ao trabalhador subcontratado ou intermediado, assim dispondo:

Artículo $3^{\circ}$.- Todo patrono o empresario que utilice subcontratistas o intermediarios permanecerá, no obstante, obligado subsidiariamente al pago de los salarios mínimos fijados.

Foi, contudo, com a lei $\mathrm{n}^{\mathrm{o}} 18.099$ de janeiro de 2007, que se dispensou tratamento integral ao instituto em voga, alterando, inclusive, o regime de responsabilidade do empresário principal. Referido conjunto de artigos traz em sua introdução a informação de que a lei em questão estabelece normas para a proteção dos trabalhadores ante o processo de descentralização empresarial.

174 DELGUE, Juan Raso. La contratación atípica del trabajo. Montevideo: Editorial Amalio M. Fernández, 2003, p. 229.

${ }^{175}$ Em GARMENDIA, Mario \& GAUTHIER, Gustavo. Tercerizaciones - Análisis de las leyes $n^{\circ} 18.099$ y 18.251 y su aplicación jurisprudencial. 2 ed., Montevideo: Fundación de Cultura Universitaria, 2012, p. 74. 
Trata-se de uma evolução legislativa decorrente do reconhecimento das mazelas sociais que a terceirização trouxe à sociedade uruguaia, em uma tentativa de restabelecimento e apaziguamento dos conflitos sociais provenientes do fenômeno econômico neoliberal.

Assim dispõe o art. $1^{\circ}$ deste texto normativo:

Artículo $1^{\mathrm{o}}$. Todo o patrono o empresario que utilice subcontratistas, intermediarios o suministradores de mano de obra, será responsable $\underline{\text { solidario de las obligaciones laborales de éstos hacia los trabajadores }}$ $\underline{\text { contratados, así como del pago de las contribuciones a la seguridad }}$ $\underline{\text { social a la entidad provisional que corresponda, de la prima de }}$ accidente de trabajo y enfermedad profesional y de las sanciones $y$ $\underline{\text { recuperos que se adeuden al Banco de Seguros del Estado en relación }}$ a esos trabajadores. (grifo nosso)

Referido dispositivo traz que a obrigação das empresas subcontratantes não se restringirá meramente aos seus direitos trabalhistas decorrentes do contrato de trabalho, mas também das obrigações derivadas da seguridade social, ao prêmio devido ao instituto de seguros de acidente e doença ocupacional e, ainda, às sanções e demais dívidas relacionadas a estes trabalhadores e que seja credor o Banco de Seguros do Estado.

Inobstante ser considerada uma evolução, a Lei em questão, por não trazer claramente um conceito relativo às espécies de subcontratação, gerou, como salientado, conflitos doutrinários e jurisprudenciais.

Motivada por tanto, foi então aprovada pelo Parlamento a Lei $\mathrm{n}^{\circ} 18.251$, de janeiro de 2008, que, pela primeira vez no direito uruguaio, traz um conceito positivo do que se trata o fenômeno em estudo. Eis o texto, constante do art. $1^{\circ}$-A:

Artículo $1^{\circ}$. A los efectos de la ley $n^{\circ} 18.099$, de 24 de enero de 2007:

A)(Subcontratación). Existe subcontratación cuando un empleador, en razón de un acuerdo contractual, se encarga de ejecutar obras o servicios, por su cuenta y riesgo y con trabajadores bajo su dependencia, para un tercera persona física o jurídica, denominada patrono o empresa principal, cuando dichas obras o servicios se 
encuentren integrados en la organización de éstos o cuando formen parte de la actividad normal o propia del establecimiento, principal o accesoria (mantenimiento, limpieza, seguridad o vigilancia), ya sea que se cumplan dentro o fuera del mismo.

Como se verifica, a lei supra aproximou-se do dispositivo contido na súmula 331, do C. TST, bem ainda ao quanto dispõe o art. 30, da LCT argentina, em um franco retrocesso à proteção do trabalhador.

Nesse contexto, passou-se a exigir a existência de um vínculo contratual entre duas empresas e, ainda, que as obras ou serviços terceirizados se encontrem integrados na organização da empresa principal ou formem parte da atividade normal ou própria do estabelecimento, seja principal ou acessória, que se cumpram dentro ou fora do local das atividades.

A responsabilidade do empresário principal será subsidiária $\left(\operatorname{art.} 6^{\circ}\right.$ ), desde que exerça o direito de informação que lhe cabe, ou seja, exija da empresa subcontratada o seguinte, de acordo com o art. $4^{\circ}$ da lei 18.251:

Artículo $4^{\circ}$. (Información sobre el cumplimiento de las obligaciones laborales y de seguridad social).- Todo patrono o empresario que utilice subcontratistas, intermediarios o suministradores de mano de obra tiene derecho a ser informado por éstos sobre el monto y el estado de cumplimiento de las obligaciones laborales, previsionales, así como las correspondientes a la protección de la contingencia de accidentes de trabajo y enfermedades profesionales que a éstos correspondan respecto de sus trabajadores.

A esos efectos, queda facultado a exigir a la empresa contratada la exhibición de los siguientes documentos:

A) Declaración nominada de historia laboral (artículo 87 de la Ley $\mathrm{N}^{\circ} 16.713$, de 3 de setiembre de 1995) y recibo de pago de cotizaciones al organismo previsional.

B) Certificado que acredite situación regular de pago de las contribuciones a la seguridad social a la entidad previsional que corresponda (artículo 663 de la Ley $\mathrm{N}^{\mathrm{o}} 16.170$, de 28 de diciembre de 1990). 
C) Constancia del Banco de Seguros del Estado que acredite la existencia del seguro de accidentes del trabajo y enfermedades profesionales.

D) Planilla de control de trabajo, recibos de haberes salariales y, en su caso, convenio colectivo aplicable.

Asimismo, podrá requerir los datos personales de los trabajadores comprendidos en la prestación del servicio a efectos de realizar los controles que estime pertinentes.

Exercendo o direito em questão, o empresário principal responderá apenas subsidiariamente pelos créditos inadimplidos pelo empregador. Do contrário, cairá na regra da responsabilidade solidária.

Contudo, interessante notar que o texto do art. $1^{\mathrm{o}}$ da Lei $\mathrm{n}^{\mathrm{o}} 18.251$, inobstante ser derivado de um conflito de ideias acerca do conceito da subcontratação, não deixa claro o que se trata por obras ou serviços integrados à organização da empresa principal, bem ainda o que seja atividade própria ou normal do estabelecimento empresarial, principal ou acessória.

Tais critérios se mostram mais uma vez ineficazes à proteção do trabalhador, vez que são subjetivos. Dessa forma, o posicionamento ideológico e o recorte científico inadequadamente adotados pelo intérprete determinarão, portanto, a completa isenção da responsabilidade do empresário subcontratante.

Indicando um caminho a se seguir na análise do dispositivo do art. $1^{\circ}$, discorre o jurista e professor Mario Garmendia, em parceria com o também jurista Gustavo Gauthier, em novíssima obra:

Aplicado el concepto a las vicisitudes de la organización empresarial en los procesos de descentralización productiva, las partes faltantes podrían identificarse con aquellas actividades que se desarrollaban en la empresa y que en determinado momento dejaron de desarrollarse con recursos y personal propios, como consecuencia de un proceso de exteriorización. Pero también podría aludirse a aquellas actividades nuevas que la empresa principal ha resuelto incorporar para completar o complementar su ciclo productivo. Las obras y servicios encargados a terceros vendrían así a suplir o complementar (integrar) actividades 
que antes eran desarrolladas directamente por el empresario principal y también aquellas otras que se incorporan ex post al proceso productivo como consecuencia de la evolución del negocio.

(...) El requisito de la integración a la organización debe ser entendida en el sentido que tanto las obras como los servicios pasan a formar parte en un todo complejo, armónico e interdependiente que constituye la organización de la empresa principal $^{176}$.

Desta forma, segundo tal perspectiva, ainda aquelas atividades que anteriormente faziam parte do contexto empresarial podem ser externalizadas sem que haja responsabilidade solidária, ou até mesmo direta, do empresário principal.

De outro modo, para que haja ao menos a responsabilidade subsidiária do tomador, diversos requisitos devem ser cumpridos, trazendo ao trabalhador maior ônus, ante a possibilidade de quedar-se sem seus direitos trabalhistas preconizados pela lei. Patente, portanto, o retrocesso experimentado pela sociedade uruguaia.

\subsubsection{Espanha}

A doutrina espanhola dissocia os conceitos de terceirização de serviços e de subcontratação.

Segundo a jurista María Ángeles Alcalá Díaz ${ }^{177}$, há a cooperação entre indústrias para a produção e comercialização de produtos como estratégia de expansão dos negócios. Tal fenômeno se caracteriza:

“(...) Bajo la denominación de subcontratación de la producción se incluyen las decisiones estratégicas de organización de la empresa en las que total o parcialmente se trasladan a otras empresas externas la fabricación del producto bajo la marca y según las características y métodos definidos por la empresa descentralizada."

No mesmo sentido, destaca o Professor David Montoya Medina ${ }^{178}$ :

${ }^{176}$ GARMENDIA, Mario \& GAUTHIER, Gustavo. Tercerizaciones..., p. 97.

${ }^{177}$ DÍAZ, María Ángeles Alcalá. Técnicas jurídico-contratuales de descentralización empresarial (p. 95162). In: GAETA, Lorenzo y MOYA, Rosario Gallardo (orgs.). Los empresarios complejos: un reto para el Derecho del Trabajo. 1 ed., España: Editorial Bomarzo, 2010, p. 102.

${ }^{178}$ MEDINA, David Montoya. Trabajo en contratas y protección de los trabajadores. Valencia: Tirant Lo Blanch, 2004, p. 53. 
“(...) la ciencia económica otorga a la subcontratación un doble sentido. En una acepción amplia, designa toda descentralización al exterior de la empresa de las actividades o fases que integran su ciclo productivo. En un sentido estricto, cuando se habla de subcontratación se hace referencia a la operación mediante la que una empresa encomienda a otra la ejecución de una parte de la producción o de ciertos servicios."

Trata-se de um modelo de produção, como destacado, que se baseia na fragmentação do ciclo produtivo em um contexto geral de interdependência ou coordenação entre as empresas, formando-se, assim, uma rede. Formalmente, contudo, observa-se a autonomia jurídica e econômica.

De acordo com a pesquisa revelada pela autora, há dois tipos evidenciados de subcontratação - aquela em que há, de fato, a independência econômica das empresas, todas trabalhando para o desenvolvimento de um produto mediante o desenvolvimento tecnológico, troca de informações e conhecimento, de modo que se nota uma rede horizontal, com mesmo nível de competitividade no mercado. Sua finalidade é a especialização da atividade desenvolvida, com o fito do aprimoramento da qualidade do produto.

Interessante, neste contexto, destacar trecho da análise da jurista ${ }^{179}$ :

"Las grandes alianzas entre empresas creando redes horizontales se establecen generalmente en los mercados internacionales y las empresas intervinientes pretenden desarrollar un amplio elenco de actividades interrelacionadas y complementarias para abastecer distintos mercados, sin que cada empresa tenga que asumir los costes y sobre todo, el desarrollo tecnológico de cada una de dichas actividades. Con frecuencia este tipo de alianzas se realiza entre grandes empresas, mediante fórmulas en las que se evidencia la igualdad de los contratantes y a menudo, operan en el mismo sector económico y, por tanto, técnicamente, son competidoras. En estos casos, la finalidad general es el incremento de la competitividad de cada una de las empresas que componen la red, pero el objetivo inmediato es la especialización en una parte de la actividad de producción, condicionada por las necesidades de inversión en

${ }^{179}$ DÍAZ, María Ángeles Alcalá. Técnicas jurídico-contratuales..., p. 106. 
tecnología e información para el desarrollo de dicha actividad. Ello explica que este tipo de redes se haya generalizado en algunos sectores económicos (automoción, informática, electrónica, etc.) que presentan altos estándares de desarrollo tecnológico e innovación y el ahorro de costes en este concepto ha aconsejado la externalización de parte de la producción."

Por outro lado, a prática demonstra também a existência de redes de empresas em um conjunto piramidal (vertical, portanto), em que a grande empresa traslada para diversas pequenas empresas auxiliares parte de sua produção, em uma franca expansão da precarização das condições de trabalho. Neste caso, observa-se nitidamente o controle exercido pela grande empresa sobre as demais, estabelecendo relação de dependência e subordinação.

Nesta situação observa-se como característica principal condições de desigualdade entre as empresas, sendo que a grande empresa descentralizadora, mediante a imposição de condições de produção e do desenvolvimento dos aspectos empresariais, consegue estabelecer uma relação de dependência econômica e de subordinação para com as subcontratadas. Nada obstante, a relação formalmente estatuída está regular; as empresas mantêm autonomia jurídica e, ainda, trabalham por instrumentos contratuais verossímeis, como o arrendamento de obra, contratos de distribuição ou de franquia, condição esta imposta pela subcontratante.

Interessante notar, também, como observa a autora ${ }^{180}$ :

\footnotetext{
"En relación con la subcontratación de la producción, el pacto de exclusiva suele incluirse de manera frecuente, aunque, de forma general, es a éstas últimas a las que se impone dicho pacto, sin que, paralelamente, se imponga restricción alguna en este sentido, al empresario principal. Así, en la descentralización de la producción, el pacto de exclusiva se impone a las empresas auxiliares a fin de evitar que puedan utilizar los conocimientos adquiridos como consecuencia de la contrata con el empresario principal a favor de empresas competidoras. En estos casos, el pacto de exclusiva no es recíproco, toda vez que el empresario principal puede formalizar contratos con empresas auxiliares como estime conveniente sin que se apliquen
}

${ }^{180}$ Op. cit., p. 120. 
restricciones contractuales de esta naturaleza ni de carácter geográfico ni cuantitativo."

A exclusividade de produção das empresas auxiliares para com a grande empresa denota a aludida dependência econômica e a subordinação, de modo que a existência de cada uma das primeiras depende exclusivamente do contrato mantido com a segunda e, dessa forma, a manutenção de seus empregos. Enquanto a subcontratante pode contratar com diversas subcontratadas ao mesmo tempo, fragmentando cada nicho de produção à uma subcontratada, esta fica sujeita à observação da produção em exclusividade para a outra, sob pena, inclusive, de multa contratual ou até mesmo de sua quebra.

A subordinação se evidencia, mais uma vez, pelo estabelecimento de condições produtivas pela grande empresa às auxiliares; verifica-se que há evidente obrigação de fazer imposta, e não apenas de resultado (produção). Impõe a subcontratante um manual de instruções a ser seguido pelas subcontratadas, de cujo descumprimento, ademais, lhes podem advir sanções.

Observa-se, portanto, patente extensão dos poderes de direção do empresário subcontratante, ainda que desempenhada a produção em local diverso de sua sede.

Neste contexto de descentralização empresarial que é nosso objeto de estudo, assim como o ordenamento jurídico brasileiro, adverte a autora em voga que há verdadeira inadequação do direito do trabalho espanhol ao novo fenômeno de descentralização empresarial.

Isto porque o art. 42 do Estatuto dos Trabalhadores traz em seu bojo a possibilidade de responsabilidade da empresa subcontratante de forma solidária; contudo, contempla apenas hipóteses específicas de descumprimento de obrigações trabalhistas por parte das subcontratadas, como às dívidas salariais e de seguridade social, e não a outros direitos individuais ou coletivos dos trabalhadores; somente se verificará a responsabilidade da subcontratante quando esta proceda à subcontratação de atividade própria (inobstante as dificuldades de se apresentar um conceito a esta expressão); e, por fim, as responsabilidades cessarão após um ano do final do contrato. 
Eis o texto do referido artigo ${ }^{181}$ :

Sección $2^{\mathrm{a}}$. (Actualizado a fecha de 15 de octubre de 2011)

Garantías por cambio de empresario.

Artículo 42. Subcontratación de obras y servicios.

1. Los empresarios que contraten o subcontraten con otros la realización de obras o servicios correspondientes a la propia actividad de aquellos deberán comprobar que dichos contratistas están al corriente en el pago de las cuotas de la Seguridad Social. Al efecto, recabarán por escrito, con identificación de la empresa afectada, certificación negativa por descubiertos en la Tesorería General de la Seguridad Social, que deberá librar inexcusablemente dicha certificación en el término de treinta días improrrogables y en los términos que reglamentariamente se establezcan. Transcurrido este plazo, quedará exonerado de responsabilidad el empresario solicitante.

2. El empresario principal, salvo el transcurso del plazo antes señalado respecto a la Seguridad Social, y durante el año siguiente a la terminación de su encargo, responderá solidariamente de las obligaciones de naturaleza salarial contraídas por los contratistas y subcontratistas con sus trabajadores y de las referidas a la Seguridad Social durante el período de vigencia de la contrata. No habrá responsabilidad por los actos del contratista cuando la actividad contratada se refiera exclusivamente a la construcción o reparación que pueda contratar un cabeza de familia respecto de su vivienda, así como cuando el propietario de la obra o industria no contrate su realización por razón de una actividad empresarial.

3. Los trabajadores del contratista o subcontratista deberán ser informados por escrito por su empresario de la identidad de la empresa principal para la cual estén prestando servicios en cada momento. Dicha información deberá facilitarse antes del inicio de la respectiva prestación de servicios e incluirá el nombre o razón social del empresario principal, su domicilio social y su número de identificación fiscal. Asimismo, el contratista o subcontratista deberán informar de la identidad de la empresa principal a la Tesorería General de la Seguridad Social en los términos que reglamentariamente se determinen.

181 Disponível em http://www.ugt.es/DatoBasico/estatutodelostrabajadoresactualizado.pdf, acesso em 02/10/2012. 
4. Sin perjuicio de la información sobre previsiones en materia de subcontratación a la que se refiere el artículo 64 de esta Ley, cuando la empresa concierte un contrato de prestación de obras o servicios con una empresa contratista o subcontratista, deberá informar a los representantes legales de sus trabajadores sobre los siguientes extremos:

a) Nombre o razón social, domicilio y número de identificación fiscal de la empresa contratista o subcontratista.

b) Objeto y duración de la contrata.

c) Lugar de ejecución de la contrata.

d) En su caso, número de trabajadores que serán ocupados por la contrata o subcontrata en el centro de trabajo de la empresa principal.

e) Medidas previstas para la coordinación de actividades desde el punto de vista de la prevención de riesgos laborales.

Cuando las empresas principal, contratista o subcontratista compartan de forma continuada un mismo centro de trabajo, la primera deberá disponer de un libro registro en el que se refleje la información anterior respecto de todas las empresas citadas. Dicho libro estará a disposición de los representantes legales de los trabajadores.

5. La empresa contratista o subcontratista deberá informar igualmente a los representantes legales de sus trabajadores, antes del inicio de la ejecución de la contrata, sobre los mismos extremos a que se refieren el apartado 3 anterior y las letras b) a e) del apartado 4 .

6. Los trabajadores de las empresas contratistas y subcontratistas, cuando no tengan representación legal, tendrán derecho a formular a los representantes de los trabajadores de la empresa principal cuestiones relativas a las condiciones de ejecución de la actividad laboral, mientras compartan centro de trabajo y carezcan de representación. Lo dispuesto en el párrafo anterior no será de aplicación a las reclamaciones del trabajador respecto de la empresa de la que depende.

7. Los representantes legales de los trabajadores de la empresa principal y de las empresas contratistas y subcontratistas, cuando 
compartan de forma continuada centro de trabajo, podrán reunirse a efectos de coordinación entre ellos y en relación con las condiciones de ejecución de la actividad laboral en los términos previstos en el artículo 81 de esta Ley. La capacidad de representación y ámbito de actuación de los representantes de los trabajadores, así como su crédito horario, vendrán determinados por la legislación vigente y, en su caso, por los convenios colectivos de aplicación.

Alerta a autora, contudo, que a jurisprudência e a doutrina vêm interpretando o disposto no item " 1 " de forma extensiva, ou seja, de acordo com o espírito protetor da norma, e não em seu sentido literal.

Desta feita, se aplicaria a responsabilidade solidária independentemente do tipo de atividade que se subcontrata em todas as facetas em que se apresente descentralização produtiva ou de distribuição, independentemente do tipo de contrato que estejam vinculadas as empresas subcontratante e subcontratada.

O que se observa, neste sentido, é que

$$
\begin{aligned}
& \text { “con el instrumento contractual utilizado se cree una relación } \\
& \text { interempresarial de colaboración por la que se posibilite que una } \\
& \text { empresa preste una obra o servicio a favor de otra bajo criterios de } \\
& \text { subordinación y dependencia. Se exige en este sentido que la } \\
& \text { subordinación de las empresas auxiliares respecto de la empresa } \\
& \text { principal no sólo implique una interdependencia económica, sino } \\
& \text { también una posición jerárquica y de control ejercitado por ésta sobre } \\
& \text { aquellas. (...) }
\end{aligned}
$$

Entendemos, contudo, que sob esta análise de integração da estrutura da empresa principal, não há que se falar em mera responsabilização solidária das empresas, solução que se adotaria apenas de forma residual. Neste contexto, cremos que a solução mais acertada seja a declaração do vínculo de emprego dos empregados da empresa auxiliar para com a subcontratante (grande empresa), assim como os empresários, já que estão apenas travestidos pela figura do pequeno empreendedor, dependendo exclusivamente do contrato com que mantém com aquela.

\footnotetext{
${ }^{182}$ DÍAZ, María Ángeles Alcalá. Técnicas jurídico-contratuales..., p. 156.
} 
O empresário real é o detentor dos meios de produção da grande empresa que, inclusive, condiciona o estabelecimento de um contrato - seja este a que título for desde que observadas a devida sistemática de produção, suas regras, a exclusividade e, muitas vezes, a ingerência da subcontratante.

É o que defende a jurista Elena Desdentado Daroca ${ }^{183}$, com base na existência de fraude à relação de trabalho:

"En definitiva, el empresario será, a pesar de toda apariencia formal, quien reciba la prestación, dirija la ejecución de esa prestación y quien se apropie de su utilidad patrimonial, como se deduce de la remisión implícita del número 2 del art. 1 al número 1 del mismo precepto. Es este "test" el que resultará definitivo. Si la empresa es solvente y tiene su propia organización productiva, pero, en el caso concreto, se limita a ceder trabajadores a otro empresario, que es quien realmente ejercita los poderes empresariales y quien hace suyos los frutos del trabajo, existirá interposición."

Desta forma, a subcontratação vertical em voga nada mais seria a empresa subcontratada do que uma intermediadora de mão de obra, em ordem a preservar a grande empresa dos custos da mão de obra.

183 DAROCA, Elena Desdentado. La responsabilidad del empresario en la descentralización productiva. Un análisis crítico del art. 42 del estatuto de los trabajadores (p. 185-212). In: GAETA, Lorenzo y MOYA, Rosario Gallardo (orgs.). Los empresarios complejos: un reto para el Derecho del Trabajo. 1 ed., España: Editorial Bomarzo, 2010, p. 192. 


\section{O PRINCÍPIO CONSTITUCIONAL DA PROIBIÇÃO AO RETROCESSO SOCIAL}

\subsection{Crise e nova hermenêutica constitucional}

Há pouco tempo vive-se no direito brasileiro, em termos de hermenêutica Constitucional, um fenômeno completamente distinto do que até então se observou das Cartas Constitucionais, notadamente no que tange aos direitos humanos fundamentais.

Nota-se que o texto contemporâneo conferiu grande ênfase aos direitos de segunda geração (especialmente quanto aos direitos sociais), e, portanto à proteção da sociedade civil, fato distinto dos principais temas das constituições anteriores, que privilegiaram a forma de organização do Estado.

Com a Carta de 1988, abandona-se a velha hermenêutica dos princípios constitucionais que marcou a interpretação do juspublicismo no final do século XIX e até a metade do século XX, que tinha como base fundamental o caráter eminentemente programático de suas normas, ou seja, a carência de normatividade, invocada propositadamente, segundo salienta o eminente Professor Paulo Bonavides, "para retirar-lhes o sentido normativo de cláusulas operacionais. ${ }^{184,}$

Nesta velha hermenêutica constitucional dos princípios, observa-se sua cisão em duas fases, sendo a primeira marcada pelo jusnaturalismo, e a segunda de cunho positivista.

No jusnaturalismo, como se tem como viga mestra os direitos como sendo inexoráveis à existência humana, tal qual o direito à liberdade e à vida ("um conjunto de verdades objetivas derivadas da lei divina e humana" ${ }^{, 185}$ ), há uma evidente característica metafísica, abstrata. Os princípios que permeiam a norma constitucional estão em um patamar abstrato, acima das leis, mas que se servem apenas de elemento norteador, jamais entrando na esfera dogmática; sua normatividade é nula, portanto, o que demonstra seu caráter eminentemente programático.

\footnotetext{
${ }^{184}$ BONAVIDES, Paulo. Curso de direito constitucional, 25 ed., São Paulo, Malheiros: 2009, p. 259.

${ }^{185}$ FLÓRES-VALDÉS, Joaquín Arces. Los Principios Generales del Derecho y su Formulación Constitucional, p. 38, apud BONAVIDES, Paulo, Op. Cit., p. 261.
} 
Essa teoria ressurge após um longo reinado do positivismo no direito e nos princípios, de modo que até mesmo era motivo de vergonha em sua manifestação, haja vista que não era tida como um método efetivo de interpretação do direito - na obra clássica "Os Princípios Gerais de Direito", o filósofo e professor alemão Peter Berger preferia trocar a expressão "Direito Natural" contida por "ideia de Direito"186 (Rechtsidea), ressaltando ainda mais seu caráter metafísico e, portanto, afastado do direito, denotando a distância em que se encontravam os princípios das normas - até se observar a insuficiência do ordenamento jurídico para a solução das questões fáticas que se apresentam.

A partir do final do século XIX até a primeira metade do século XX observouse, com a elaboração dos códigos, a expansão doutrinária do positivismo, fase esta na qual ocorre a teorização dos princípios nestes diplomas, resolvendo o problema da insuficiência normativa, funcionando, como interpreta Gordillo Cañas ${ }^{187}$, "para estender sua eficácia de modo a impedir o vazio normativo", da mesma forma que "garante o reinado absoluto da lei"

Mas, da mesma forma que o jusnaturalismo, os princípios acabam por padecer de irrelevância jurídica, segundo adverte o Professor Paulo Bonavides, uma vez que são considerados meras pautas programáticas supralegais, carecendo, ainda, de efetiva normatividade. Ou seja, inobstante estarem escritos, como dever de observância, esvaziam-se porque não pretendem adentrar sua eficácia, o que se depreende de sua própria redação.

A fim de superar essa dicotomia, que reinou na filosofia do direito por um grande período, fala-se hoje em neoconstitucionalismo ${ }^{188}$, em nova hermenêutica Constitucional, bem como do pós-positivismo. Trata-se de um marco filosófico da atualidade, denotando a necessidade de incluir os princípios tais quais normas cuja

\footnotetext{
${ }^{186}$ DE DIEGO, Felipe Clemente, "Prólogo", in Giorgio Del Vecchio, apud BONAVIDES, Paulo, Op. Cit., p. 260.

${ }^{187}$ GORDILLLO CAÑAS, "Ley, principios generales y Constitución...". In: Anuario de Derecho Civil, t. LXI, fasc. 2, abr./jun. 1988, PP. 484 e 485, apud BONAVIDES, Paulo, Op. Cit., p. 262.

${ }^{188}$ BARROSO, Luís Roberto. Neoconstitucionalismo e constitucionalização do direito - o triunfo tardio do direito constitucional no Brasil. In: Revista da Escola da Magistratura do Tribunal Regional do Trabalho da $2^{a}$ Região, Ano 2, $n^{\circ} 2$ (set.2007), São Paulo, Semestral, Revista Oficial do TRT da $2^{a}$ Região - São Paulo, p. 11-52.
} 
vinculação social ocorra da mesma forma que a lei formalmente construída pelo Poder Legislativo.

Atribui-se à Constituição da República de 1988 fundamental importância no direito, uma vez que não apenas trata de temas técnicos relacionados à forma de governo ou ao Estado, mas, principalmente, aos direitos naturais também positivados, de forma que refletem, por conseguinte, segundo afirma o Prof. Tércio Sampaio Ferraz Jr., um indício de enfraquecimento desta dicotomia "jusnaturalismo-positivismo", de forma que o direito natural, anteriormente visto como algo imanente à natureza e compulsório ao homem, agora é observado pelo Estado ${ }^{189}$.

Introduziu-se, portanto, no ordenamento posto, a necessidade de observância dos preceitos de dignidade e, principalmente, de interpretação de acordo com o objetivo de se fazer justiça social. Nascem, desta forma, a normatividade dos princípios e a reaproximação dos conceitos axiológicos ao direito, não mais de forma metafísica, mas posta, proporcionando a formação de uma nova interpretação da Constituição e o desenvolvimento de uma teoria dos direitos fundamentais construída sobre a dignidade humana ${ }^{190}$.

Neste sentido, afirma Robert Alexy serem os princípios também normas, "porquanto ambos [regras positivadas e princípios] se formulam com a ajuda de expressões deônticas ${ }^{191}$ fundamentais, como mandamento, permissão e proibição"192, o que se exemplifica pelo próprio princípio da legalidade, constitucionalmente previsto, segundo o qual ninguém será obrigado a fazer ou deixar de fazer algo senão em virtude de lei (art. $5^{\circ}$, inciso II), ou o próprio princípio de vedação do retrocesso social, que será melhor estudado adiante, e se faz presente em diversas passagens constitucionais, como no $\S 2^{\circ}$ do art. $5^{\circ}$ ou do caput do art. $7^{\circ}$ da norma constitucional.

\footnotetext{
${ }^{189}$ FERRAZ JR., Tércio Sampaio. Introdução ao Estudo do Direito, 3 ed., São Paulo: Atlas, 2001.

${ }^{190}$ BARROSO, Luís Roberto, Op. Cit., p. 16.

191 Proveniente de deontologia - indagação do fundamento da ordem jurídica e da razão da obrigatoriedade das normas de Direito, da legitimidade da obediência às leis, o que quer dizer indagação dos fundamentos ou dos pressupostos éticos do Direito e do Estado. In: REALE, Miguel. Filosofia do Direito, 12 ed., São Paulo: Saraiva, 1987, p. 308. Logo, por deôntico diz-se a carga de obrigatoriedade da norma, sua vinculação, o dever que carrega de ser cumprida.

192 ALEXY, Robert. Theorie der Grundrechte, apud BONAVIDES, Paulo. Curso de direito constitucional, 25 ed., São Paulo: Malheiros editores, 2009, p. 277.
} 
O emérito Prof. Paulo Bonavides, seguindo o quanto o professor alemão propugna, afirma ser a normatividade dos princípios algo inerente ao ordenamento constitucional, se convertendo, por isso, "no coração das Constituições"193, do que se pode depreender, finalmente, que todos os princípios constitucionais contêm, por si só, carga obrigacional, devendo ser respeitados tal qual normas postas e, portanto, ter sua sanção igualmente aplicada diante de descumprimento.

Para se chegar à nova teoria da hermenêutica Constitucional, o Direito brasileiro atravessou forte crise em todo seu sistema. Tal crise é relativa à efetividade de suas normas, e cujo estudo, a iniciar-se pela crise do Estado do Bem-Estar Social é imprescindível para a compreensão da nova hermenêutica, notadamente do princípio da vedação do retrocesso.

Segundo Norberto Bobbio ${ }^{194}$, o "Welfare-State" é “o Estado que garante tipos mínimos de renda, alimentação, saúde, habitação, educação, assegurados a todo cidadão, não como caridade, mas como direito político".

Conforme tratado no Capítulo 1, o Estado do Bem-Estar Social não se fez presente em território brasileiro, de forma que a brusca transição entre o fordismo aos novos métodos de produção do toyotismo provocou ainda mais rachaduras na já desestruturada sociedade brasileira, uma vez que o Estado foi incapaz de absorver a nova massa de pessoas marginalizadas do mercado de trabalho, a migração para os grandes centros urbanos, a criação de infra-estrutura e, portanto, o recrudescimento da pobreza. A falta de políticas públicas eficientes marcam a inefetividade das normas de cunho social positivadas na Constituição de 1988 e, então, a crise constitucional se torna evidente.

O modelo em voga, vem, portanto, enfrentar no Brasil crises já avançadas do "Welfare State", nos anos 70, diversamente dos países ocidentais de capitalismo mais avançado, visto que o descompasso entre gastos e receitas fazem com que haja o crescimento do déficit público - então, a queda da assistência social é consequência lógica. Nos anos 80, há a crise ideológica, patrocinada pelo embate entre

\footnotetext{
${ }^{193}$ Op. Cit., p. 281.

${ }^{194}$ BOBBIO, Norberto. Dicionário de Política, Brasília: UNB, 1986, Verbete 'Estado do Bem Estar', p. 416, apud STRECK, Lênio Luiz. Jurisdição Constitucional e Hermenêutica, Op. Cit., p. 56.
} 
democratização do acesso aos serviços públicos e a respectiva burocratização do atendimento, e, por fim, há a crise filosófica, própria do sistema jurídico.

Esta atinge os fundamentos do Estado do Bem-Estar, calcada na solidariedade, impondo um enfraquecimento ainda maior no conteúdo tradicional dos direitos sociais, característicos deste Estado.

Neste escólio, afirma o Prof. Lênio Streck ${ }^{195}$ que é neste momento que o projeto neoliberal encontra terra fértil no Brasil, de forma que:

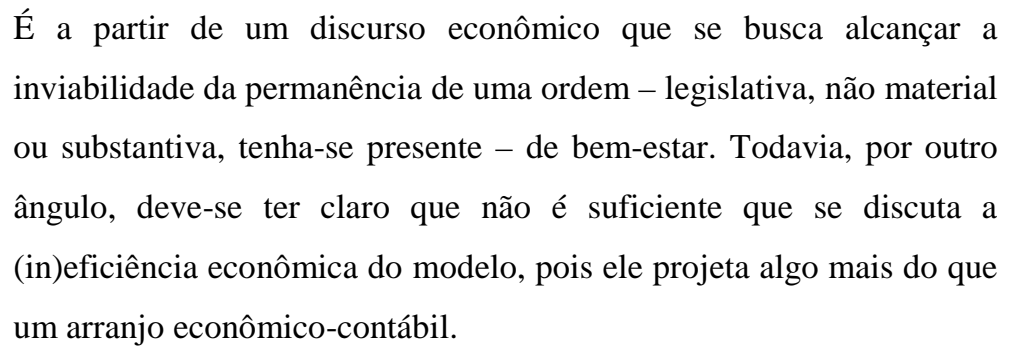

Todavia, muito embora não seja apenas o que glorificou o aparato de inefetividade de normas sociais, o arranjo econômico foi a viga-mestra de um projeto capitalista elaborado para que fosse possível realizar cortes nos gastos públicos. E, neste sentido, como afirma o mesmo professor, os cortes incidem sobre gastos sociais, seguidos de compulsiva venda de patrimônio público a preços desvalorizados. Nesse sentido, o Brasil está repleto de contundentes exemplos, como a venda da Vale do Rio Doce, da Usiminas, entre tantas outras empresas públicas ${ }^{196}$.

Seguindo-se o modelo neoliberal, o Estado foi beneficente apenas às camadas privilegiadas da sociedade, que se aproveitaram da sua prodigalidade neste período. Para o professor Lênio Streck ${ }^{197}$, as camadas superiores:

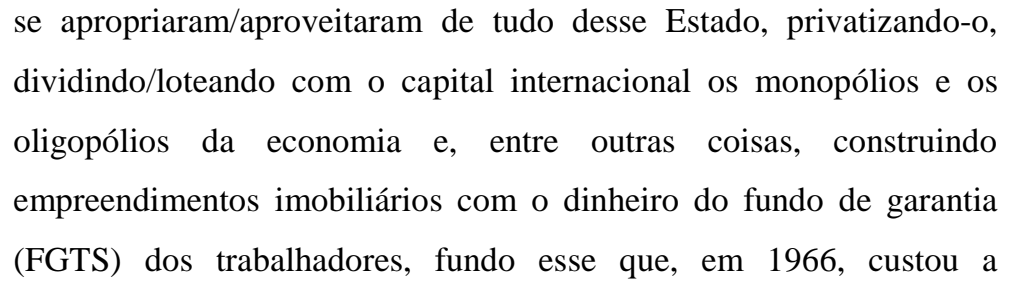

\footnotetext{
${ }^{195}$ STRECK, Lênio Luiz. Op. Cit., p. 59.

${ }^{196}$ Op. Cit., p. 61.

${ }^{197}$ Idem, p. 62.
} 
estabilidade no emprego para os milhões de brasileiros! (...) No Brasil, a modernidade é tardia e arcaica.

Depreende-se, portanto, que se está diante de uma simulação da existência de um Estado e da modernidade, bem como da continuidade de um modelo aristocrático do Brasil agrário, o que aponta ainda mais fortemente para uma crise; uma verdadeira contradição entre as normas propugnadas como princípios, objetivos e valores de uma nação e o que realmente impera em terras brasileiras.

Exsurge desta ideia, portanto, a pós-modernidade, ou, de acordo com Zygmunt Bauman $^{198}$, a "modernidade líquida", caracterizada, principalmente, pelo rompimento dos valores sociais e coletivos, em razão do afastamento do Estado e do domínio pelas empresas privadas; a extrema fluidez do consumo e da sociedade, onde a cada tempo, é necessário substituir o velho pelo novo; a libertação de qualquer tipo de rigidez é necessária, de modo que flexibilizar, desregulamentar, liberalizar, ser fluido, ou seja, ser cambiante são as palavras de ordem. E, quem dita as ordens, é a sociedade de consumo, que é fluida, leve, cambiante; mero instrumento de uma sociedade aristocrática que detém os meios de produção e o poder do Estado nas mãos.

E, tal conceito, forçoso admitir, também tenta se apropriar do ordenamento jurídico, que, a todo custo, para os neoliberais, a troco de uma suposta sobrevivência na concorrência mundial, tem de adaptar-se, flexibilizando-se e desregulamentando-se, para a finalidade de permitir o perfeito funcionamento desta fluidez. Sem dúvida, tais estratégias resultam no enfraquecimento dos institutos constitucionais, que deveriam funcionar como o aporte principal das normas de hierarquia inferior e, portanto, a razão de sua própria existência, tendo como função primordial o enfrentamento de quaisquer das ofensivas pós-modernas como ataque direto ao texto constitucional.

Uma vez que, todavia, os projetos desregulamentadores e flexibilizadores são aprovados e postos em prática, o texto constitucional se desguarnece de força política, restando comprometido o controle de constitucionalidade.

${ }^{198}$ BAUMAN, Zygmunt. Modernidade Líquida. Rio de Janeiro: Zahar, 2000, p. 7 e ss. 
Enfrentando a questão, Boaventura de Souza Santos sinaliza no sentido de que "precisamos de um Estado cada vez mais forte para garantir os direitos num contexto hostil de globalização neoliberal ${ }^{199}$,.

Isto porque, sem a necessária redoma política para a contenção da poderosa autonomia de vontade capitalista, é certo que quem ditará as regras será esta dita autonomia; a nova economia globalizada, com seu artefato industrial comprometido à maximização dos lucros, superará as barreiras legais e abastecerá o mundo com produtos criados para necessidades criadas, a preços mínimos, ofendendo, de uma só vez, dois preceitos básicos - a concorrência leal e o ordenamento jurídico interno de proteção ao trabalhador.

Assim, o Estado, por óbvio, se enfraquece; a ideia de Nação se enfraquece, passando o país ao status de mero agenciador político, recebendo e cumprindo ordens dos agentes econômicos externos, que ditam as regras da competitividade.

Substitui-se, desta forma, segundo Streck, “a política pelo mercado (...) fazendo surgir um pluralismo político marcado pela desinstitucionalização do Direito, que açambarca cada vez mais espaços - Lex mercatoria, direito marginal, etc. - ou a pax americana imposta pelas possibilidades militarizadas de definir os rumos da política em alguns locais do planeta. Esse processo leva ao fenômeno da desregulamentação, variante menor de propostas de desconstitucionalização. ${ }^{200,}$

Inevitável, portanto, falar-se em crise do Estado Democrático de Direito brasileiro e da necessidade de implementação da nova proposta hermenêutica, uma vez que, conforme colocado, o país não passou por uma maturação política adequada às exigências e mutações sociais, subvertendo sua própria ordem social à ingerência do capital, submetido ao jogo de poderes das relações próprias do capitalismo hodierno. Por fim, a própria ideia de Constituição, levada às últimas consequências, é posta em xeque, dado o histórico incisivo de negação de direitos.

Em países em que o Estado Social não existiu, o agente principal de toda política social (ainda) deve ser o Estado; isto porque não há maior dificuldade em compreender

\footnotetext{
199 "Boaventura defende o Estado forte". In: Correio do Povo, Secção Geral. Porto Alegre, 6 de abril de 1998, p. 9, apud STRECK, Lênio. Op. Cit., p. 64.
} 
que as políticas neoliberais, que visam a minimizá-lo, não apontarão para a realização de tarefas contrárias à sua própria natureza. O país segue exatamente um caminho inverso: quando países de ponta rediscutem e questionam a eficácia (social) do neoliberalismo, o Brasil pratica nos últimos anos, políticas públicas que apontam para um Estado mínimo. Trata-se, portanto, de um dilema: quanto mais são necessárias políticas públicas para o combate das misérias que se avolumam, mais o Estado é minimizado, o único agente que poderia erradicar tais desigualdades sociais.

E, neste sentido, superando o paradigma acima, Lênio Streck ${ }^{201}$ leciona:

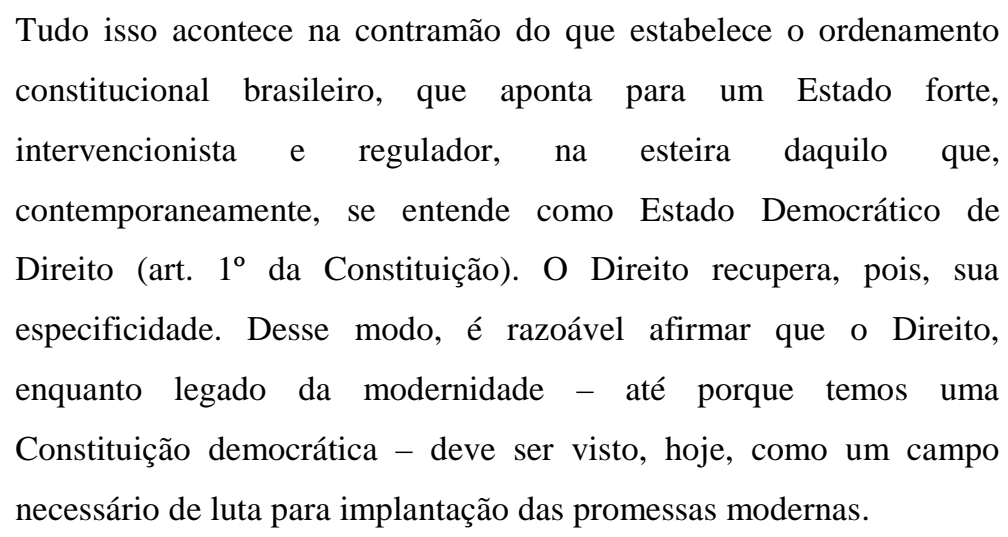

Promove-se, assim, no texto da Carta Magna, um conteúdo dirigente: ao estabelecer como norte a construção de um Estado Social, em seu artigo $3^{\circ}$, explicitando as condições necessárias para esse desiderato, como as garantias individuais e os direitos sociais, há o reconhecimento do verdadeiro não cumprimento dessas promessas da modernidade, provocado por séculos de políticas excludentes. Se há a determinação da construção de um Estado Social, é porque o pacto constituinte reconheceu a sua inexistência, sendo a partir daí, conforme mesmo afirma Streck, que se reconhece o nítido caráter dirigente da Constituição; seu perfil compromissário, apontando para a realização de políticas públicas aptas a construção de um Estado Social e Democrático de Direito ${ }^{202}$.

Os problemas, entretanto, ultrapassam a esfera econômica, dominada por países que alçaram voo nos ventos do capitalismo moderno mais precocemente e, diante de seu

\footnotetext{
${ }^{200}$ STRECK, op. cit., p. 66.

${ }^{201}$ Idem, p. 74.

${ }^{202}$ Idem, p. 76.
} 
desempenho, história e política, hoje exercem papel de liderança e, muitas vezes, de subjugador dos demais.

Neste sentido, a formação de um Estado forte, apto para conter avanços e abusos dos demais e da economia, preservando sua soberania, resta comprometida. E, assim sendo, o Estado fraco somente poderá ter uma Constituição, senão de palavras fracas, de efetividade relativa; pouco se fala da Constituição, esta tem um papel muitas vezes secundário diante das normas que lhe são hierarquicamente inferiores, de modo que acaba por tornar-se um documento alienígena da própria realidade da nação, que deveria ser nada menos que sua franca leitura e estandarte de direitos mínimos.

A isso também se atribui a crise Constitucional, e do Direito como um todo.

Afirma Streck $^{203}$, com a propriedade que lhe é peculiar, neste mesmo sentido:

\begin{abstract}
A inefetividade da Constituição está assentada num plano mais complexo, a partir da negativa dos Tribunais (assumindo maior relevância, aqui, os Tribunais Superiores) em dar efetividade aos princípios e às assim denominadas "Normas programáticas", ainda consideradas como "meramente" programáticas. Veja-se a dificuldade em fazer valer o valor da parametricidade do art. $3^{\circ}$ da Constituição, que consubstancia o Estado Social na Constituição. Uma hermenêutica adequada aponta, por exemplo, para a inconstitucionalidade de muitas das privatizações realizadas nos últimos oito anos; muito embora tais teses tenham recebido guarida na justiça federal, foram esvaziadas em grau de recurso pelo STJ e pelo STF.
\end{abstract}

Inobstante as privatizações, há de se mencionar ainda as leis aprovadas e sancionadas pelo planalto e que formalmente estão em vigor, mas que, em seu conteúdo, carregam nuanças inconstitucionais de enlevo e que, ademais promoveram o retrocesso social no direito do trabalho, e.g., o trabalho temporário (Lei 9.601/98), dentre outras leis absorvidas pela Constituição, sem o devido controle hermenêutico, como a Lei 6.019/74, que se serviu, ademais, para criar o fenômeno mais degradante dos direitos

\footnotetext{
${ }^{203}$ Idem, p. 78. Observe que o autor comenta "nos últimos oito anos", sendo que a obra data de 2004. Não seria enganoso afirmar que muitas outras privatizações posteriores estariam igualmente sob questionamento.
} 
trabalhistas já verificado, a terceirização de serviços, consolidada pelo Tribunal Superior do Trabalho mediante a Súmula 331, flagrantemente inconstitucional ${ }^{204}$.

Como se observa, o papel de uma Constituição transcende o da construção do Leviatã, ou seja, do abandono pelo indivíduo da sua mísera condição de guerra para uma harmônica vida em sociedade mediante a regulação por um poder dominante, mas a de estabelecer a máxima expansão em termos sociais e humanos, garantindo a franca evolução para uma sociedade não apenas livre de guerras e sobre a qual reside uma autoridade, mas para uma sociedade livre de injustiças sociais, soberana, capaz de promover a paz, a dignidade da pessoa humana, os valores sociais do trabalho e o bem comum.

Para tanto, mister é que seja superada a fase em que ainda estão calcadas as decisões judiciais, as súmulas e até mesmo a própria atuação legiferante, baseadas no modelo "liberal-individualista-normativista"205, que contamina os propósitos hermenêuticos constitucionais (os quais caíram prisioneiros do formalismo ${ }^{206}$ ), e que insiste em obstaculizar a atuação efetiva do Estado Democrático.

Exsurge desta crise constitucional, em contraposição à atuação limitada dos tribunais, uma maior atuação jurisdicional para se fazer cumprir os mandamentos constitucionais, de modo que a instrumentalização dos valores constitucionais e a aferição da conformidade ou não das leis ao texto constitucional se estabelecem através do que se convencionou chamar de justiça constitucional, mediante o mecanismo da jurisdição constitucional.

Neste comento, para o fim de tornarem as normas constitucionais efetivos instrumentos de direito, adquirindo real concretude, os Tribunais precisam amparar-se em pilares hermenêuticos que, a primeira vista, não seriam compreendidos por um Estado burguês conservador, mas sim por aquele que direciona seus benefícios à ordem social justa.

\footnotetext{
${ }^{204}$ Para um estudo pormenorizado da inconstitucionalidade do fenômeno da terceirização de serviços, vide: CUNHA, Tadeu Henrique Lopes da. Terceirização e seus efeitos sobre os direitos do trabalhador no ordenamento jurídico brasileiro. Dissertação de Mestrado. São Paulo: Faculdade de Direito da Universidade de São Paulo, 2007.

${ }^{205}$ Conforme propugna STRECK, Lênio Luiz. Op. Cit., p. 87.

${ }^{206}$ BONAVIDES, Paulo. Op. cit., p. 504.
} 
E, como preceitua o Prof. Streck ${ }^{207}$, os princípios são tais pilares, de modo que:

\begin{abstract}
Assumem relevância os princípios constitucionais, incidindo sobre o ordenamento e sobre a aplicação do ordenamento. Há um efeito de irradiação provocado pelos princípios, questão que pode ser observada nos tribunais constitucionais europeus e no desenvolvimento da teoria da argumentação jurídica, na medida em que toda a interpretação se submete aos princípios. (...) A consequência mais importante tem sido a acentuada transferência do protagonismo do Poder Legislativo em direção à Justiça Constitucional, a ponto de autores como Alexy falarem de uma "omnipotência dos Tribunais". Este deslocamento da esfera de tensão em direção do Poder Judiciário (ou à Justiça Constitucional) tem sido considerado por muitos como uma grave lesão ao princípio democrático.
\end{abstract}

Ora, não se trata de ferir e causar lesão grave à democracia, mas sim de finalmente estabelecer, após quase 25 anos de promulgação da Constituição da República, o verdadeiro enlace entre os preceitos de uma sociedade que escolheu para si como normas fundamentais, os direitos sociais e a realidade em que se vive, desprovida por completo de qualquer política pública proveniente do executivo ou mesmo de leis que venham realmente outorgar ao povo o que de direito lhe pertence.

Em iguais termos, parafraseando o ex-Ministro Eros Roberto Grau ${ }^{208}$ : "No Estado Democrático de Direito, e tomando em conta o conteúdo da Constituição brasileira de 1988, é proibido falar em normas programáticas!"

Pondera o Prof. Luís Roberto Barroso ${ }^{209}$, no mesmo sentido da nova hermenêutica Constitucional, designando que:

\footnotetext{
Modernamente, já não cabe negar o caráter jurídico e, pois, a exigibilidade e acionabilidade dos direitos fundamentais, na sua múltipla tipologia. É puramente ideológica, e não científica, a resistência que ainda hoje se opõe à efetivação, por via coercitiva, dos chamados direitos sociais.
}

\footnotetext{
${ }^{207}$ Idem, p. 103

${ }^{208}$ Apud STRECK, idem, ibidem.

209 BARROSO, Luís Roberto. O direito constitucional e a efetividade de suas normas, 5 ed., Rio de Janeiro: Renovar, 2001, p. 106.
} 
Trata-se mais, portanto, de ceder o parlamento à soberania da Constituição, e não se fazer valer mais um poder que outro; a submissão dos juízes à lei foi suplantada pela prevalência dos direitos dos cidadãos, garantido pelo poder constituinte originário, face às vontades políticas efêmeras e voláteis do Estado.

Propõe-se, contudo, um intervencionismo judicial longe das algemas autoritárias, mas baseadas em uma necessidade ínsita do estabelecimento de uma igualdade não apenas formal, da tentativa de reduzir o abismo social observado desde a construção da Nação, e se fazer valer, a todos, os princípios democráticos e os direitos fundamentais, assim como Andreas Krell ${ }^{210}$ pondera:

onde o processo político se omite na implementação de políticas públicas e dos objetivos sociais nela implicados, cabe ao Poder Judiciário tomar uma atitude ativa na realização desses fins sociais através da correição de prestações dos serviços sociais básicos.

Vale ressaltar que o Poder Judiciário respeitando a própria divisão política da Constituição, não deve interferir em esfera reservada a outro poder, exceto nas hipóteses em que haja violação evidente e arbitrária pelo legislador, da incumbência constitucional, como mesmo ressalta o autor acima. Não se trata, portanto, de invasão dos poderes constitucionalmente individualizados, mas sim do suprimento de uma função estatal indispensável e não cumprida.

Oportuno, nesta esteira de pensamentos, citar a brilhante lição de Alexy ${ }^{211}$ :

$$
\begin{aligned}
& \text { Quem pretenda escrever na Constituição ideais políticos não } \\
& \text { justiçáveis, deve ser consciente do que está em jogo. Com uma só } \\
& \text { disposição da Constituição não controlável judicialmente abre-se o } \\
& \text { caminho para a perda de sua obrigatoriedade. }
\end{aligned}
$$

E, em razão deste risco é que o Poder Judiciário deve agir no sentido de fazer valer as normas constitucionais mesmo que sob o apelo do ativismo judicial, tão

\footnotetext{
${ }^{210}$ KRELL, Andreas Joachim. "Realização dos Direitos Fundamentais Sociais Mediante Controle Judicial da Prestação dos Serviços Públicos Básicos”. In: Anuário dos Cursos de Pós-Graduação em Direito, $\mathrm{n}^{\circ}$ 10, Recife: UFPE, 2000, p. 56-57, apud STRECK, op. cit., p. 186.

211 ALEXY, Robert. "Los derechos fundamentales en el Estado Constitucional Democrático". In: Neoconstitucionalismo(s), p. 33, apud STRECK, idem, p. 188, nota de rodapé $\mathrm{n}^{\circ} 58$.
} 
criticado, mas indispensável para solucionar os problemas aventados pela crise Constitucional.

Não se pode olvidar, neste mesmo sentido, como complemento às razões atinentes ao Poder Judiciário apontadas da referida crise, o histórico colonizador do Brasil. Tendo sido proclamada a República, no final do século XIX, o Brasil, mesmo independente de Portugal, mantinha em sua mais alta Corte de justiça, o Supremo Tribunal de Justiça, membros originários das Cortes de Relação, instituídos pelo próprio colonizador.

Mesmo após a substituição desta corte pelo STF, aproveitou-se a maior parte dos ministros do antigo tribunal da monarquia, sendo alguns deles Viscondes e Barões.

Por muito tempo, portanto, o país ficou inconsciente da importância de seu texto constitucional, bem ainda do controle de constitucionalidade das leis, uma vez que, mesmo com a nomenclatura alterada, mantiveram-se as mesmas estruturas aristocráticas.

Com isso se explica parte da crise constitucional brasileira, isto é, a pouca importância que se tem dado ao direito constitucional e ao próprio texto constitucional, que, inobstante ter seguido os modelos de Constituições dirigentes do segundo pósguerra, privilegiando os direitos fundamentais, até hoje causa sofreguidão aos jurisdicionados quando se discute a efetividade de tais direitos.

Tendo sido relegada a um plano secundário a Constituição, hermeneuticamente foram estabelecidos limites à sua própria aplicação, de modo que, consequentemente, o legislador ordinário se erigia em dono absoluto dos conteúdos da Constituição, podendo desenvolvê-los com maior ou menor amplitude, ou, inclusive, desconhecê-los, sem que nem os cidadãos e nenhum outro órgão do Estado pudessem ser capazes de reprovar tais comportamentos. Na prática, muito embora as várias constituições brasileiras já existentes, sempre prevaleceram os Códigos, sendo relegados àquelas os assuntos eminentemente organizacionais e políticos. 
Mesmo com o advento da Constituição de 1988, ainda é considerável o movimento de resistência ao texto, "mormente naquilo que ele tem de ab-rogante e no seu papel de filtragem hermenêutica" ${ }^{212}$.

Desta forma, de modo a superar os antigos padrões, rompendo com a tradição que ora se tem e que não proporciona uma interpretação autêntica, em favor da pessoa humana, torna-se necessário compreender o sentido da Constituição, para o fim de entendê-la como um mecanismo prático que provoca mudanças na realidade.

Certo é, todavia, que a efetividade dos direitos sociais de um modo positivo, ou seja, de forma a se exigir uma prestação positiva do Estado trata-se de um problema mais complexo que se pode imaginar.

O cumprimento de um direito pode esbarrar no que se denomina por “financeiramente possível", ou "reserva do possível", isto é, aquilo que o indivíduo pode razoavelmente exigir do aparelho estatal. Tal cláusula expressa a necessidade de sua ponderação, notadamente diante do limitado orçamento público. Tal limitação, entretanto, muitas vezes é possível de ser transposta mediante a oposição de valores juridicamente tuteláveis superiores ao do orçamento público, como da vida e dignidade humanas.

Em outras situações, entretanto, as normas constitucionais geram situações prontamente desfrutáveis, como os direitos dos trabalhadores inscritos no art. $7^{\circ}$ da Constituição, bastando apenas a abstenção do ente estatal para sua plena eficácia.

Vale dizer: o Estado não poderá agir contra estas normas, sob pena de praticar atos impugnáveis, ou, como bem disciplina o Prof. Barroso ${ }^{213}$, “desviando-se os atos de quaisquer dos Poderes da diretriz lançada pelo comando normativo superior, viciam-se por inconstitucionalidade, pronunciável pela instância competente”.

Desta forma, tais normas, ditas programáticas, por força hermenêutica, revogam, como salientado, os atos normativos anteriores que disponham em sentido colidente com o princípio que substanciam, e, ainda, trazem consigo um juízo de

\footnotetext{
${ }^{212}$ STRECK, Op. Cit., 216.

${ }^{213}$ Op. Cit., p. 121.
} 
inconstitucionalidade para os atos normativos editados posteriormente, se com elas incompatíveis.

Logo, o indivíduo que se torna titular de um direito, ao ver-se ameaçado pela própria ordem jurídica, por ato que vise sua limitação de exercício, poderá, segundo leciona Barroso ${ }^{214}$ :

\footnotetext{
a) Opor-se judicialmente ao cumprimento de regras ou à sujeição a atos que o atinjam, se forem contrários ao sentido do preceptivo constitucional;

b) Obter, nas prestações jurisdicionais, interpretação e decisão orientadas no mesmo sentido e direção apontados por estas normas, sempre que estejam em pauta os interesses constitucionais por ela protegidos.
}

Observa-se, portanto, que ainda que a Constituição traga em seu bojo normas programáticas, a abstenção do Estado ou do particular em infringir-lhe o conteúdo é de dever aplicado de forma imediata e irrestrita, cabendo a responsabilização do ente esbulhador.

Assim, em sendo editado ato do poder executivo, ou aprovada lei pelo poder legislativo, que contenham em seu bojo este propósito, estarão eivados do vício da inconstitucionalidade, devendo ser repelidos do ordenamento, restabelecendo-se, desta forma, o status quo ante em que se encontravam os jurisdicionados prejudicados.

Incumbe afirmar que a hermenêutica constitucional volta-se hoje à satisfação das normas fundamentais, notadamente as de direito social, durante séculos negligenciadas, e cujos resultados se forçaram aparecer diante dos olhos da sociedade de forma impiedosa, mediante a marginalização dos indivíduos que a compõem.

O neoconstitucionalismo, marca da nova hermenêutica constitucional, caracterizado pela maior valoração dos princípios, em detrimento da norma posta e cujo controle hermenêutico se deixou de filtrar, pela maior exigência judicial do cumprimento das normas (jurisdição constitucional), é garantia de que, mediante os princípios e a hermenêutica, mãe da aplicação autêntica do Direito, será outorgada à sociedade maior eficácia aos direitos constitucionalmente conferidos. 
Portanto, é mister filiarmo-nos à lição de Streck $^{215}$ :

No topo do ordenamento, está a Constituição. Esta Lei Maior deve ser entendida como algo-que-constitui-a-sociedade, é dizer, a constituição do país depende de sua Constituição.

E, complementando a ideia de Streck, somente se terá um país nos moldes delineados pela sua Constituição, a contrário senso, quando efetivadas as garantias fundamentais nela expostas.

\subsection{Conceito e função dos princípios: o princípio como norma}

A nova hermenêutica Constitucional, conforme se balizou, está intrinsecamente ligada aos princípios em que se estabelece, tendo como normas fundantes de seu texto positivado os princípios, e a estes próprios uma característica de norma posta.

Desta forma, nunca na história do Direito a afirmação de que "o direito vigente está impregnado de princípios até as suas últimas ramificações” foi mais verdadeira.

Esta afirmação, do filósofo Simonius, citada por Reale em sua obra Lições Preliminares de Direito ${ }^{216}$, é fundamental para a compreensão de que, acima da norma posta, mas principalmente ao seu lado, está o princípio sobre o qual foi construída, sendo nada mais do que uma "verdade fundante", de forma que este sempre se servirá de norte para a aplicação ao fato concreto, bem como de limite teleológico para tanto.

Afirma, nesse sentido, Miguel Reale que os princípios gerais de direito são enunciações normativas de valor genérico, que condicionam e orientam a compreensão do ordenamento jurídico, quer para a sua aplicação e integração, quer para a elaboração de novas normas ${ }^{217}$.

À luz do quanto dispõe o art. $4^{\circ}$ da Lei de Introdução ao Código Civil (DecretoLei $\mathrm{n}^{\mathrm{o}}$ 4.567, de 1942), em se tratando a lei de omissa, uma vez que o legislador não exauriu, na elaboração de seu texto, a possibilidade de fatos para sua aplicação, a

\footnotetext{
${ }^{214}$ Idem, p. 122.

${ }^{215}$ Idem, p. 218.

${ }^{216}$ REALE, Miguel. Lições Preliminares de Direito. 27 ed., São Paulo: Saraiva, 2007, p. 304.

${ }^{217}$ Idem, Ibidem.
} 
integração das lacunas será feita de acordo com a analogia, os costumes e os princípios gerais de direito.

Uma vez que o princípio é a viga mestra da norma, estando sobre ele construído, afirma o Prof. Reale não ser necessário que se observe, nesta ordem, o sentido de integração das lacunas da norma, de forma que o princípio pode ser a primeira (e única) fonte para o suprimento do quanto se necessita.

Com efeito, a inserção dos princípios gerais no ordenamento até o ponto de adquirirem força coercitiva, pode operar-se através das fontes de Direito, a começar pelo processo legislativo, mas, mais frequentemente, através da atividade jurisdicional e a formação de precedentes judiciais, bem como através dos usos e costumes e da prática dos atos negociais.

Para Maria Helena Diniz ${ }^{218}$, os princípios gerais de direito contêm múltipla natureza:

\begin{abstract}
a) São decorrentes das normas do ordenamento jurídico, ou seja, dos subsistemas normativos. Princípios e norma não funcionam separadamente; ambos têm, na nossa opinião, caráter prescritivo. Atuam os princípios como fundamento de integração do sistema normativo e como limite da atividade jurisdicional.
\end{abstract}

b) São derivados das ideias políticas e sociais vigentes, ou seja, devem corresponder ao subconjunto axiológico e ao fático, que norteiam o sistema jurídico, sendo, assim um ponto de união entre consenso social, valores predominantes, aspirações de uma sociedade com o sistema de direito, apresentando, portanto, uma certa conexão com a filosofia política ou ideologia imperante, de forma que a relação entre norma e princípio é lógico-valorativa, apoiando-se estas valorações em critérios de valor "objetivo".

Como se vê, os princípios parecem rondar as normas positivadas em um suposto céu jurídico, de forma que, em caso de dúvida, de qualquer lacuna, basta olhar para cima que haverá algum tipo de orientação para o jurista. Lá de cima, entretanto,

\footnotetext{
${ }^{218}$ DINIZ, Maria Helena. Compêndio de Introdução à Ciência do Direito. 20 ed., São Paulo: Saraiva, 2009, p. 475.
} 
inobstante a afirmação de Josef $\operatorname{Esser}^{219}$, de que "enquanto são princípios, eles são eficazes independentemente do texto legal”, sendo consagrados ao atribuir à norma um juízo prévio, parecem não denotar uma característica cogente, coercitiva.

Nesta perspectiva, a violação do princípio por si só não corresponderia à violação de uma norma em especial, mas corresponderia à violação de todo um sistema, de uma ordem fundante, tal qual os alicerces de uma estrutura, colocando-se, conforme conclusão de Reale ${ }^{220}$, como "as bases teóricas ou as razões lógicas do ordenamento jurídico, que deles recebe o seu sentido ético, a sua medida racional e a sua força vital ou histórica."

Todavia, inobstante os magnos conceitos atribuídos pelos juristas em voga e que refletem exatamente o conceito geral dos princípios no Direito da Modernidade, Paulo Bonavides afirma que todos os conceitos de princípios até então formulados se baseiam em orientações e diretrizes de caráter geral e fundamental de um ordenamento jurídico, que norteiam tanto a aplicação das normas como sua elaboração, em linhas gerais. Ocorre, todavia, que o mesmo professor indica haver um "defeito capital" nesta conceituação, uma vez que todos omitem o traço característico dado pela doutrina contemporânea, qual seja, a sua normatividade.

A normatividade dos princípios, afirmada categórica e precursoramente, pode ser encontrada "excelente e sólida conceituação" formulada em 1952 pelo jurista e constitucionalista genovês Crisafulli ${ }^{221}$ :

\footnotetext{
Princípio é, com efeito, toda norma jurídica, enquanto considerada como determinante de uma ou de muitas outras subordinadas, que a pressupõem, desenvolvendo e especificando ulteriormente o preceito em direções mais particulares (menos gerais), das quais determinam, e portanto resumem, potencialmente, o conteúdo: sejam, pois, estas efetivamente postas, sejam, ao contrário, apenas dedutíveis do respectivo princípio geral que as contém.
}

\footnotetext{
${ }^{219}$ Apud REALE, op. cit., p. 305.

${ }^{220}$ Idem, p. 317.

${ }^{221}$ CRISAFULLI, Vezio. La costituzione e le sue disposizioni di principio, p. 15, apud BONAVIDES, Paulo. Op. Cit., p. 257.
} 
Interessante notar que o progresso dos estudos jurídicos de forma progressista já ocorria na Itália desde muito antes no Brasil, o que denota ainda mais o atraso jurídicocientífico em que o país ainda estava imerso na década de 50. Nesta época, em terras brasileiras, eram viçosos os entendimentos baseados nas políticas liberais, estando a indústria em franca expansão, e, portanto, o amadurecimento dos problemas sociais só viria a ocorrer décadas mais tarde.

Outrossim, os princípios tendiam a ficar no conforto das teorias jusnaturalistas, onde pouco se ousava falar de sua aplicação, sob pena de haver um suposto confronto entre a lei posta e um princípio.

Cabe salientar que os contornos estabelecidos por Crisafulli são seguidos por Bobbio $^{222}$, para quem:

Os princípios gerais são apenas, a meu ver, normas fundamentais ou generalíssimas do sistema, as normas mais gerais. A palavra princípio leva a engano, tanto que é velha questão entre os juristas se os princípios gerais são normais como todas as outras. E esta é também a tese sustentada por Crisafulli. Para sustentar que os princípios gerais são normas, os argumentos são dois, e ambos válidos: antes de mais nada, se são normas aquelas das quais os princípios gerais são extraídos, através de um procedimento de generalização sucessiva, não se vê por que não devam ser normas também eles: se abstraio da espécie animal (p. 158) obtenho sempre animais, e não flores ou estrelas. Em segundo lugar, a função para qual são extraídos e empregados é a mesma cumprida por todas as normas, isto é, a função de regular um caso. E com que finalidade são extraídos em caso de lacuna? Para regular um comportamento não-regulamentado: mas então servem ao mesmo escopo a que servem as normas expressas. E por que não deveriam ser normas?

E, para solucionar a questão, como norma deve-se entender a "regra de conduta", fato este que define o próprio direito, como um todo.

A regra de conduta, entretanto, pode se dividir em uma gama variada - regras sociais, morais, religiosas, de convivência, etc., ou como coloca Bobbio ${ }^{223}$, "são regras

\footnotetext{
${ }^{222}$ BOBBIO, Norberto. Teoria do Ordenamento Jurídico. 10 ed., Brasília: Editora Universidade de Brasília, 1999, p. 158-159.
} 
de conduta tanto os dez mandamentos quanto às prescrições do médico, tanto os artigos de uma Constituição quanto as regras do xadrez ou do bridge", de forma que se tornam incalculáveis. O que as caracteriza como normas é o fato de que tanto a sociedade como o indivíduo, ao estabelecer objetivos a atingir, estipula também os meios mais adequados para atingi-los.

Portanto, passará a ser jurídica a norma no momento em que passa a ser uma experiência jurídica, ou seja, é a norma institucionalizada, emanada de uma sociedade organizada e que estabelece uma ordem social, isto é, ordenada aos cidadãos ${ }^{224}$.

Pode-se, é certo, questionar se de toda norma violada nasce uma sanção. Pelo contrário, é fato inconteste que em todo ordenamento jurídico existem normas não sancionadas, o que, todavia, não as descaracteriza enquanto norma jurídica. Dessa forma, não se pode utilizar o pretenso argumento de que o princípio não teria força normativa porque de sua inobservância, por si só, não se sobressai a força de constranger à sua observância.

Neste sentido, Bobbio $^{225}$ leciona que não se pode negar às normas não sancionadas o caráter de normas jurídicas, vez que se trata de uma solução radical e desnecessária. Em verdade, a solução para este problema dá-se da seguinte forma:

\footnotetext{
Observando que quando se fala em uma sanção organizada como elemento constitutivo do direito, nos referimos não às normas singulares, mas ao ordenamento normativo tomado no seu conjunto, razão pela qual, dizer que a sanção organizada distingue o ordenamento jurídico de todo outro tipo de ordenamento não implica que todas as normas desse sistema sejam sancionadas, mas apenas que o seja a maior parte. (...) O critério da juridicidade não é certamente a sanção, mas a pertinência ao sistema, ou a validade, no sentido já aclarado de referibilidade da norma a uma das fontes de produção normativa reconhecidas como legítimas.
}

\footnotetext{
${ }^{223}$ BOBBIO, Norberto. Teoria da Norma Jurídica. São Paulo: Edipro, 2001, p. 26.

${ }^{224}$ BOBBIO, Op. Cit., 2001, p. 29.

${ }^{225}$ Idem, Ibidem, p. 167.
} 
No caso dos princípios, trata-se de "normas estabelecidas por autoridade tão alta na hierarquia das normas que se torna impossível, ou pelo menos pouco eficiente, a aplicação de uma sanção. ${ }^{226, "}$

Cabe dizer que serão os princípios, portanto, dotados de sanções distintas daquelas que se aplicam às normas, porquanto a ofensa é muito maior, transcendendo a um código ou ao texto constitucional, mas afetando toda a ordem jurídica estabelecida. Neste caso, o ato, se emanado de autoridade, é eivado de nulidade, porquanto incompatível com todo o sistema jurídico posto.

Destarte, no pós-positivismo, fase correspondente aos grandes momentos constituintes das últimas décadas do século XX, traz a nova Constituição a hegemonia axiológica dos princípios, "convertidos em pedestal normativo sobre o qual assenta todo o edifício jurídico dos novos sistemas constitucionais ${ }^{227, "}$.

E, por assim ser, os princípios erigem em torno de si as soluções para as mais diversas situações conflituosas, servindo-se, portanto, não apenas de elemento integrador da norma, sanando-lhes as omissões, mas também de juízo precursor e de finalidade dessa mesma norma, notadamente por ser base para uma nova hermenêutica Constitucional, onde adquirem caráter normativo.

A velha hermenêutica Constitucional, caracterizada no período que vai do final do século XIX e início do século XX, tem como mestre clássico o italiano Emilio Betti, o qual considera que não se pode empreender em nenhuma tentativa, no que tange aos princípios, de reduzi-los, fixá-los, ou traduzi-los em termos preceptivos, de forma que estariam fadadas ao fracasso tais tentativas.

Isso se deve, explica o doutrinador, em razão de que o princípio seria uma "ideia germinal", "um critério de avaliação", de modo que serve à norma, nunca, entretanto, servindo como norma acabada e formulada.

Ressalta, ainda, o célebre autor a antinomia insuperável, que se estabelece, "de um lado, entre a exigência, que todo preceito jurídico levanta de ser formulado em termos normativos, de tal sorte que permita uma interpretação jurídica e uma construção

${ }^{226}$ Idem, Ibidem. 
dogmática e, doutra parte, a repugnância que os princípios opõem a uma formulação preceptiva exata, enquanto afirmam orientações e ideais de política legislativa, capazes de indefinida, quase diria, inexaurível virtualidade" ${ }^{228}$.

Amadurecida a posição doutrinária acerca dos princípios, reconhece Josef Esser que "o princípio atua normativamente; é parte jurídica e dogmática do sistema de normas, é ponto de partida ("starting point") que se abre ao desdobramento judicial de um problema" 229 , de forma que não mais se tem, portanto, o princípio como mero indicador de uma hermenêutica superada, estando ao lado das normas positivadas.

Interessante destacar, segundo doutrina do Prof. Paulo Bonavides ${ }^{230}$, que por princípios gerais devem ser entendidos, em sentido e substância, os princípios constitucionais.

E, por assim ser, são os princípios normas primárias. Podem os princípios considerarem-se normas eles mesmos, principalmente se codificados; hoje, com mais razão, se inseridos nas Cartas Constitucionais, portanto.

A construção doutrinária da normatividade dos princípios provém, em grande parte, do empenho da Filosofia e da Teoria Geral do Direito em buscar um campo neutro onde se possa superar a antinomia clássica Direito Natural/Direito Positivo.

São momentos culminantes de uma revolução doutrinária, de que resultam para a compreensão dos princípios jurídicos importantes mudanças e variações acerca do entendimento de sua natureza: admitidos definitivamente por normas, "são normasvalores com positividade maior nas Constituições do que nos Códigos; por isso mesmo providos, nos sistemas jurídicos, do mais alto peso, por constituírem a norma de eficácia suprema $^{231 \% ;}$ essa norma, por conseguinte, não pode deixar de ser o princípio.

No que tange às funções dos princípios na nova hermenêutica, como mesmo preleciona Bobbio, não são mais atinentes apenas as funções tradicionais de fonte

\footnotetext{
${ }^{227}$ BONAVIDES, op. cit., p. 264.

${ }^{228}$ BETTI, Emilio. Teoria generalle della interpretazione, II, p. 846, apud BONAVIDES, Op. Cit., p. 269.

${ }^{229}$ ESSER, Josef. Grundsatz und norm in der richterlichen fortbildung des privatrechts, $3^{\mathrm{a}}$ tir., p. 69 , apud BONAVIDES, Op. Cit., p. 271.

${ }^{230}$ Op. Cit., p. 274.

${ }^{231}$ Idem, p. 276.
} 
orientadora do trabalho de interpretação e de fonte em caso de insuficiência legislativa. Reconhece-se, conforme o jurista espanhol F. de Castro demonstra, a função de ser "fundamento da ordem jurídica, com eficácia derrogatória e diretiva", sem dúvida a mais relevante, de enorme prestígio no Direito Constitucional contemporâneo. ${ }^{232}$

Certo é que a proclamação da normatividade dos princípios em novas formulações conceituais corroboram à tendência irresistível que conduz à valoração e eficácia dos princípios como normas-chaves de todo o sistema jurídico; normas das quais se retirou o conteúdo inócuo de programaticidade, mediante o qual se costumava neutralizar a eficácia das Constituições em seus valores reverenciais, em seus objetivos básicos, em seus princípios cardeais.

Considerar de forma diferente, conforme brilhantemente aduz Crisafulli ${ }^{233}$, seria negar validade à própria norma posta:

(...) se os princípios fossem simples diretivas teóricas, necessário seria, então, admitir coerentemente que em tais hipóteses a norma é posta pelo juiz, e não, ao contrário, por este somente aplicada a um caso concreto.

Não há, portanto, pelo que até ora foi posto, distinção entre princípios e normas; os princípios são dotados de normatividade, as normas compreendem regras e princípios, a distinção relevante não é, como nos primórdios da doutrina, entre princípios e normas, mas entre regras e princípios, sendo as normas o gênero, e as regras e os princípios a espécie.

Daqui se caminha para o passo final da incursão teórica a que propõe Paulo Bonavides $^{234}$ com a nova hermenêutica Constitucional observada com a normatividade dos princípios: a demonstração do reconhecimento da superioridade e hegemonia dos princípios na pirâmide normativa; supremacia que não é unicamente formal, mas sobretudo material, e apenas possível na medida em que os princípios são compreendidos e equiparados e até mesmo confundidos com os valores, sendo, na

\footnotetext{
${ }^{232}$ Citado por Flóres-Valdés, apud BONAVIDES, Op. Cit., p. 284.

${ }^{233}$ CRISAFULLI, La Costituzione..., p. 16., apud BONAVIDES, Op. Cit., p. 287.

${ }^{234}$ Op. Cit., p. 288.
} 
ordem constitucional dos ordenamentos jurídicos, a expressão mais alta da normatividade que fundamenta a organização do poder.

Os princípios, enquanto valores fundamentais, governam a Constituição, o regime jurídico, a ordem jurídica. Não são, portanto, apenas a lei, mas "o Direito, em toda a sua extensão, substancialidade, plenitude e abrangência"235.

Observa-se, por fim, a importância vital que os princípios assumem para os ordenamentos jurídicos, notadamente se lhes forem examinadas a função e a presença no corpo das Constituições contemporâneas, onde aparecem como os pontos axiológicos de mais alto destaque e prestígio.

Assim postos no ponto mais alto da escala normativa, eles mesmos, sendo normas, se tornam, doravante, as normas supremas do ordenamento, servindo-se de parâmetros ou critérios por excelência para a avaliação de todos os conteúdos normativos que se seguirão no ordenamento.

E, desta forma, atuando, conforme preceitua Bonavides ${ }^{236}$ :

Os princípios, desde sua constitucionalização, que é ao mesmo passo positivação no mais alto grau, portanto, recebem como instância valorativa máxima categoria constitucional, rodeada do prestígio e da hegemonia que se confere às normas inseridas na Lei das Leis. Com esta relevância adicional, os princípios se convertem igualmente em norma normarum, ou seja, norma das normas.

Por tudo quanto discorrido, mister depreender que na esfera jusprivatista, marcada pelo liberalismo acentuado, os princípios unicamente serviam à lei, possuindo no sistema o seu mais baixo grau de hierarquização positiva, como fonte secundária de normatividade - ou, ainda, mera fonte interpretativa e integradora, sem força determinante.

Doravante, colocados na esfera juspublicística, ou seja, do Direito Público, notadamente Constitucional, as posições se invertem: os princípios, em grau de positivação, se encarregam de residir no ápice do sistema, guiando e fundamentando

\footnotetext{
${ }^{235}$ Idem, p. 289.

${ }^{236}$ Idem, p. 290.
} 
todas as demais normas que a ordem jurídica institui. Trata-se de uma nova versão de legitimidade da ordem jurídica, com fundamento único no próprio texto Constitucional, rompendo-se, por fim, com a crise que assola o Direito e, principalmente, a própria Constituição.

Não é demais admitir, portanto, que a nova hermenêutica Constitucional trouxe ao Direito uma fase de hegemonia e preeminência dos princípios, de forma que os conflitos não resolvidos com pauta na lei posta, o serão, com a mesma força, com os princípios, dado que, como finaliza Bonavides, são estes "a viga-mestra do sistema, o esteio da legitimidade constitucional, o penhor da constitucionalidade das regras de uma Constituição",237.

\subsubsection{O princípio da proibição ao retrocesso social}

De acordo com o estudo da nova hermenêutica Constitucional, observa-se da Carta Magna de 1988, notadamente de seu caráter dirigente, de presença ampla do Estado nas relações sociais (especialmente no que tange à relação capital-trabalho, objeto do presente estudo), que a proteção conferida aos direitos fundamentais é vasta e possui caráter aberto. Entretanto, inobstante a presença ostensiva, constata-se um rol não exaustivo de direitos, conforme mesmo preceitua o $\S 2^{\circ}$ do artigo $5^{\circ}$ do Texto, abaixo transcrito:

$\S 2^{\circ}$. Os direitos e garantias previstos nesta Constituição não excluem outros decorrentes do regime e dos princípios por ela adotados, ou dos tratados internacionais em que a República Federativa do Brasil seja parte.

Verifica-se, portanto, que se açambarcam no rol dos direitos fundamentais também os princípios protetivos adotados pela Constituição e por quaisquer outros regimes legais que venham a ser aplicados em território brasileiro, notadamente aqueles trazidos pelos tratados internacionais.

Com isso, pode-se depreender que os artigos constitucionais entrelaçam-se, sendo a Constituição um texto alinhavado no sentido de se cumprir os objetivos

${ }^{237}$ Idem, p. 294. 
estabelecidos pela República em seu art. $3^{\circ}$ e 170 , notadamente de justiça social e solidariedade, com vistas à redução progressiva das desigualdades sociais.

Desta forma, está imposta ao legislador infraconstitucional a impossibilidade de adotar regimes legais que importem no retrocesso de proteção aos direitos fundamentais. Igualmente, lhe é proibido deixar de regulamentar, em sede legislativa, uma norma constitucional que lhe estabeleça tal dever, cabendo, inclusive, os recursos judiciais para que se faça valer tal direito, a exemplo do mandado de injunção (art. $5^{\circ}$, inciso LXXI) e da ação direta de inconstitucionalidade por omissão (art. 103, § $2^{\circ}$ ), bem como de outros recursos judiciais.

Neste sentido, Felipe Derbli ${ }^{238}$, proeminente procurador e professor carioca que explora a contento o princípio em voga, estabelece:

\footnotetext{
Uma vez alcançado determinado patamar de concretização de uma norma constitucional definidora de direito social, através de lei, será defeso ao legislador suprimir ou reduzir essa concretização, sem que, ao menos, crie algum mecanismo equivalente ou substituto.
}

Cabe dizer que, portanto, o conteúdo material estabelecido pela Constituição da República quanto aos direitos e garantias fundamentais é imutável; seu núcleo de proteção a tais direitos não pode ser atingido, ainda que reflexamente, por uma lei que venha a suprimir, reduzir ou limitar seus efeitos, sob pena de ser declarada inconstitucional.

Certo é que, como ressaltado no presente capítulo, as normas garantidoras de direitos fundamentais dividem-se em normas definidoras de direitos, sendo estas aquelas que geram direitos imediatamente desfrutáveis (como as férias aos empregados, ou direito de greve, colocados, respectivamente, nos artigos $7^{\circ}$ e $9^{\circ}$ da Constituição); as que exigem prestações positivas do Estado, e que podem esbarrar na "reserva do possível" (o que não inibe, entretanto, sua possibilidade de questionamento judicial); as que demandam edição de norma regulamentadora, e, por fim, as normas programáticas.

\footnotetext{
238 DERBLI, Felipe. O princípio da proibição de retrocesso social na Constituição de 1988. Rio de Janeiro: Renovar, 2007, p. 223.
} 
Tecendo séria, contundente e real crítica a esta última classe de normas, Derbli $^{239}$ assim realça:

Percebe-se, de imediato, que, parte considerável do pensamento jurídico contemporâneo ainda baralha as normas constitucionais definidoras de direitos sociais - especialmente aquelas que envolvem prestações positivas do Estado - e as normas programáticas. Com efeito, trata-se de reminiscência histórica da reação burguesa ao surgimento do constitucionalismo social, especialmente a partir do final da Primeira Guerra Mundial, quando as constituições, inspiradas principalmente pelos modelos da Carta mexicana de 1917 e da Constituição da República de Weimar (1919), passaram a conter também a tutela de interesses dos setores economicamente menos favorecidos da sociedade. Sem outra saída, a classe burguesa arvorouse no amesquinhamento da normatividade das disposições voltadas para a promoção da justiça social, lançando-as ao mundo cor-de-rosa das exortações e promessas constantes das normas programáticas. Recorda Cláudio Pereira de Souza Neto: “Quando se quis, nos últimos vinte anos, deixar de aplicar a Constituição, bastou-se etiquetar a norma suscitada como programática e transferir para o legislador uma tarefa que, muitas vezes, era mesmo do Judiciário."

Desta forma, as normas programáticas, ou normas que contém os fins sociais a serem alcançados pelo Estado, passaram a ser apenas disposições que fixam diretrizes, programas de ação para o Poder Público, para o fim de concretizar os objetivos constitucionais delineados no artigo $3^{\circ}$ da Carta Constitucional. Nestas normas, especialmente, e a contragosto da referida classe burguesa, encontra-se também a vedação do retrocesso, uma vez que, inobstante não determinem uma ação específica do Estado, assim como as demais normas classificadas acima, estabelecem também, normatividade, gerando a não recepção material dos atos posteriores que com elas forem incompatíveis; permitindo-se, ainda, ao administrador, conforme complementa Derbli, "opor-se às normas infraconstitucionais e aos atos contrários às normas programáticas e a obtenção, na prestação jurisdicional, de interpretação e aplicação do Direito em consonância com o conteúdo dessas normas. ${ }^{240,}$

\footnotetext{
${ }^{239}$ Op. Cit., p. 227.

${ }^{240}$ Op. Cit., p. 226.
} 
Neste particular, não seria demais afirmar que as normas flexibilizadoras do direito do trabalho, por conta da incompatibilidade substancial que lhes é ínsita, são contrárias ao princípio de vedação do retrocesso, de forma que, invariavelmente, se não esbarrassem nos obstáculos políticos para tanto, segundo a autêntica hermenêutica proposta, estariam eivadas completamente pelo vício da inconstitucionalidade em razão do seu conteúdo material, devendo ser repelidas pelo ordenamento jurídico brasileiro.

Como será visto, a subcontratação, em algumas de suas vertentes, constitui-se em um franco avanço à flexibilização das normas de direito do trabalho e, principalmente, instrumento de precarização das condições de trabalho, inobstante não tenha sobre si um regramento no ordenamento, cabendo discutir, portanto, a validade dos contratos civis celebrados entre as empresas contratantes e subcontratadas, bem como o vínculo de emprego dos empregados envolvidos nesta relação, e a consequente responsabilidade pelo adimplemento de suas verbas trabalhistas.

O que cabe ressaltar é que, independente de se tratarem as normas de aplicação imediata, limitada ou programática, o princípio da vedação do retrocesso está positivado em todas estas, aplicando-se, de acordo com a nova hermenêutica, imediata e irrestritamente a todas as relações sociais e leis formalmente aprovadas após a promulgação da Constituição da República de 1988.

Isso porque a necessidade de uma norma infraconstitucional para a completude de uma norma programática parte apenas de uma exigência instrumental ou técnica, a fim de dirigir a prestação positiva do Estado, alcançando, mediante os meios determinados pela referida lei, os fins colimados pela Carta Constitucional, o que não impede, entretanto, de já se verificar, ainda que como um imperativo categórico, a existência do direito subjetivo ao indivíduo, e, portanto, a impossibilidade de sua violação, uma vez que sua complementação pelo Legislativo passará pela aferição dos valores e do momento oportuno para a criação da lei.

Com fim exemplificativo, encontra-se a norma exposta no art. 170, inciso VIII da Carta Magna, a qual coloca como um dos princípios da ordem econômica a "busca do pleno emprego". Trata-se de uma norma programática, porquanto não estabelece ao legislador uma tarefa concreta, determinada, de editar ato que regulamente tal disposição constitucional. Não se impõe ao legislador o dever de criar lei que indique 
quando se deveria ter uma situação de "pleno emprego" ou em quais casos poderia o indivíduo exigir que o Estado ou algum particular lhe concedesse um emprego; admitir o contrário seria reduzir à inocuidade e à impossibilidade o cumprimento do comando constitucional.

Em contrapartida, a edição de normas que venham a reduzir as possibilidades de emprego, ocasionando desemprego estrutural ou incrementando ainda mais o desemprego (e não seria demais afirmar as práticas de mercado que também apontam para este fim), estariam diretamente em confronto com o princípio em questão, sendo combatidas, decerto, pelos instrumentos jurídicos de controle de constitucionalidade.

Em suma, conforme ressalta Derbli, o "princípio em questão veda ao legislador subtrair da norma constitucional definidora de direitos sociais o grau de concretização já alcançado, prejudicando a sua exequibilidade. Vale dizer, haverá retrocesso social quando o legislador, comissiva e arbitrariamente, retornar a um estado correlato a uma primitiva omissão inconstitucional ou reduzir o grau de concretização de uma norma definidora de direito social; onde não houver imposição legiferante - e, portanto, for mais fluida a delimitação das raias da liberdade de conformação do legislador (o que ocorre no caso das normas constitucionais programáticas), não se poderá falar propriamente em proibição de retrocesso social" ${ }^{241}$, exceto se ato normativo posterior assim lhe ofender, de modo a contrariar as finalidades constitucionais expressamente expostas.

Somente caberá, portanto, o mandado de injunção ou a ação direta de inconstitucionalidade por omissão acima indicadas na hipótese em que se verificar uma imposição legiferante descumprida pelo legislador.

Nada obstante, está garantida pelo próprio ordenamento a proteção a direitos sociais já afiançados pelo constituinte originário, de forma que em conformidade com o princípio da segurança jurídica, nenhuma norma poderá ofender-lhe em sua aplicação.

Ressalta, neste comento, o Prof. Ingo Wolfgang Sarlet que o princípio do não retrocesso, ou de proibição do retrocesso, guarda íntima relação com a segurança jurídica. Tal segurança jurídica não só se refere às decisões judiciais, mas também à

${ }^{241}$ Idem, p. 240. 
segurança em dimensão mais genérica, pessoal e social, além da proteção contra atos do poder público ou da esfera privada que violem direitos pessoais ${ }^{242}$.

Assim explicita sua tese:

Com efeito, a dignidade não restará suficientemente respeitada e protegida em todo o lugar onde as pessoas estejam sendo atingidas por um tal nível de instabilidade jurídica que não estejam mais em condições de, com um mínimo de segurança e tranquilidade, confiar nas instituições sociais e estatais (incluindo o Direito) e numa certa estabilidade das suas próprias posições jurídicas. ${ }^{243}$

Cabe dizer, portanto, que os direitos conquistados, reconhecidos pelo ordenamento, são impassíveis de supressão pelo Estado, ou violação pelo particular, estando cobertos pela segurança jurídica, de forma a garantir sempre uma imposição de abstenção de atos que venham a violá-los.

Assumem, portanto, como colocam os juristas portugueses Gomes Canotilho ${ }^{244} \mathrm{e}$ Vital Moreira, os direitos fundamentais sociais "a condição de verdadeiros direitos de defesa contra medidas de cunho retrocessivo, que tenham por objeto a sua destruição ou redução".

Torna-se possível, por derradeiro, impugnar judicialmente toda e qualquer medida, proveniente da esfera pública e privada que se encontre em conflito com o teor da Constituição (inclusive com os objetivos estabelecidos nas normas de cunho programático), bem como rechaçar medidas legislativas que venham, pura $\mathrm{e}$ simplesmente, subtrair supervenientemente a uma norma constitucional o grau de concretização anterior que lhe foi outorgado pelo legislador. Observa-se, por força de conclusão, que tais normas estão devidamente protegidas pelo núcleo duro da Constituição, de forma que estão dentro das denominadas “cláusulas pétreas”, tornandose, à exceção de uma nova ordem revolucionária, impassíveis de alteração, revogação ou limitação.

\footnotetext{
242 SARLET, Ingo Wolfgang. A eficácia dos direitos fundamentais - uma teoria geral dos direitos fundamentais na perspectiva constitucional, 10 ed., Porto Alegre, Ed. Livraria do Advogado: 2009, p. 433.

${ }^{243}$ Idem, p. 434.

${ }^{244}$ CANOTILHO, J.J. Gomes. Direito Constitucional e Teoria da Constituição, p. 474-5, apud SARLET, Op. Cit., p. 440.
} 
Vale ressaltar que tal proteção não está adstrita ao legislador, constitucional ou ordinário, mas também dos demais órgãos estatais (já que medidas administrativas e decisões jurisdicionais também podem atentar contra a segurança jurídica), que, portanto, além de estarem incumbidos de um dever permanente de desenvolvimento e concretização eficiente dos direitos fundamentais (inclusive e, no âmbito da temática versada, de modo particular os direitos sociais) não poderá, igualmente e em qualquer hipótese, suprimir, restringir ou invadir o núcleo essencial dos direitos fundamentais.

O supracitado autor, entretanto, defende, com o amparo da tese de Ingo Sarlet ${ }^{245}$, que deverá haver certa relatividade na aplicação do princípio da proibição do retrocesso no que tange aos direitos sociais. Isso porque deverá haver um cotejamento da situação histórica em que o país atravessa em conjunto às proteções demandadas, como se denota de sua explanação:

\footnotetext{
A dinâmica das relações sociais e econômicas, notadamente no que concerne às demandas de determinada sociedade em matéria de segurança social e, por via de consequência, em termos de prestações sociais asseguradas pelo poder público, por si só já demonstra a inviabilidade de se sustentar uma vedação absoluta de retrocesso em matéria de direitos sociais, até mesmo pelo fato de que, no que diz com a possibilidade de sua limitação e restrição, os direitos fundamentais em geral não podem ser qualificados como absolutos, o que, de resto, já foi salientado quando da análise da eficácia "protetiva" dos limites materiais ao poder de reforma constitucional.
}

Ora, como se admitir a possibilidade de uma aplicação relativa, se não se observa do texto Constitucional, qualquer possibilidade neste sentido?

O que se verifica, portanto, é uma tentativa de justificar os avanços neoliberais sobre o Direito Constitucional, notadamente sobre o núcleo dos direitos sociais, relativizando-os para o fim de uma pseudo-adaptação às exigências mercadológicas.

Aqui, a própria interpretação gramatical resolve a questão, uma vez que o art. 60 da Carta Magna expõe, expressamente, a impossibilidade de se limitar ou cotejar a aplicação dos direitos fundamentais, sob o amparo das ações constitucionais. Seria,

${ }^{245}$ SARLET, Op. Cit., p. 450-451. 
portanto, admitir a possibilidade, em completa contradição, que tais normas poderiam ser derrogadas.

No mesmo compasso, o caput do artigo $7^{\circ}$ constitucional expressamente proíbe a vedação, do retrocesso, conforme se denota de sua transcrição:

Art. $7^{\circ}$. São direitos dos trabalhadores urbanos e rurais, além de outros que visem à melhoria de sua condição social:

Observa-se do texto a mesma progressividade de proteção conferida ao trabalhador em igual forma àquela conferida à toda pessoa humana, pari passu ao que dispõe o $\S 2^{\circ}$ do art. $5^{\circ}$ alhures destacado.

Ao estabelecer o constituinte, mediante a expressão "além de outros [direitos] que visem à melhoria de sua condição social", está determinando a intenção de se manter permanentemente um necessário progresso às suas condições, em favor da redução das desigualdades sociais intrínsecas à relação capital-trabalho, o que importa afirmar, a contrario sensu, que este é o mínimo existencial proporcionado pelo ordenamento ao trabalhador, não cabendo, seja por qualquer ótica que se analise, sua limitação ou extirpação.

Neste comento, é interessante a lição de Massimiliano Delfino ${ }^{246}$, que qualifica o non regresso pela cristalização de um nível de proteção mais favorável ao trabalhador, produzindo, por conseguinte, a substancial imutabilidade do nível geral de tutela, com o que se firma um padrão mínimo de direitos.

Desta forma, não há quaisquer exceções conferidas aos direitos sociais em questão para a aplicação do princípio da vedação do retrocesso, seja às disposições do texto constitucional como da própria hermenêutica que se vem destacando.

Inobstante as determinações Constitucionais, certo é que o Brasil é signatário, dentre diversos outros documentos internacionais, da Declaração sobre o Direito ao Desenvolvimento, da ONU, desde 1986, em conjunto com mais 145 países.

\footnotetext{
${ }^{246}$ DELFINO, Massimiliano. Il principio di non regresso nelle direttive in matéria de política sociale. In: Giornale di Diritto del Lavoro e di relazioni industriali. Milano, n. 95, a. XXIV, p. 498-511, jul/set. 2002, p. 501, apud REIS, Daniela Muradas. O princípio da vedação do retrocesso no Direito do Trabalho, São Paulo: LTr, 2010, p. 19-20.
} 
Na referida declaração, o direito ao desenvolvimento, e portanto, ao permanente progresso, é conferido à pessoa humana, como corolário da consecução dos fins de redução das desigualdades entre os países e mesmo entre o próprio povo de uma nação. O Art. $2^{\circ}$ da Declaração sobre o Direito ao Desenvolvimento, de 1986, consagra:

A pessoa humana é o sujeito central do desenvolvimento e deve ser ativa participante e beneficiária do direito ao desenvolvimento.

Tal diretiva traz o dever do Estado em promover o desenvolvimento em consonância ao desenvolvimento de seu povo, de forma que não poderá ultrapassar suas barreiras sociais, ofendendo a dignidade da pessoa humana, mediante atitudes que importem prejuízos sociais de qualquer ordem, seja pelo incremento da miséria, da marginalidade, do desemprego ou do subemprego, que implicariam, invariavelmente, no enfraquecimento e empobrecimento de toda uma nação - e, por conseguinte, o desenvolvimento suscitado seria relativo.

E, neste sentido, é pertinente a lição do ex-juiz da Corte Internacional de Justiça, Mohammed Bedjaqui, citado pela Prof ${ }^{a}$. Flávia Piovesan ${ }^{247}$, que ensina:

O direito ao desenvolvimento demanda uma globalização ética e solidária. No entender de Mohammed Bedjaqui, "na realidade, a dimensão internacional do direito ao desenvolvimento é nada mais que o direito a uma repartição equitativa concernente ao bem-estar social e econômico mundial. Reflete uma demanda crucial de nosso tempo, na medida em que os quatro quintos da população mundial não mais aceitam o fato de um quinto da população mundial continuar a construir sua riqueza com base em sua pobreza".

Os estudos indicam, portanto, que é intrínseco ao amplo e perene progresso da sociedade que os impactos da globalização sejam de toda forma minimizados, com o desenvolvimento de políticas que venham a suprir as lacunas econômicas que afetam o espectro social.

O que se observa, portanto, é a incompatibilidade de medidas de ampliação econômica que venham causar desestabilização social; a exploração de países ricos

247 BEDJAQUI, Mohammed. The right to development. In: M. Bedjaqui (Ed.) International Law: achievements and prospects, 1991, p. 1182, apud PIOVESAN, Flávia e CARVALHO, Luciana Paula Vaz (Coord). Op. Cit., p. 12. 
sobre os pobres, em seus recursos naturais e humanos são fortes desagregadores sociais, contra os quais o Estado não consegue a contento refutar, utilizando-se, contrariamente, destas formas de exploração como justificativas para um suposto desenvolvimento do país.

O conceito de retrocesso e progresso está, portanto, intimamente ligado ao desenvolvimento econômico de um país, esclarecendo o eminente Professor Washington Peluso Albino de Souza ${ }^{248}$, que retrocesso tem caráter dinâmico, refere-se à modificação do status quo e traduz um sentido negativo.

E, neste sentido, traçando as diferenciações terminológicas entre desenvolvimento, crescimento e retrocesso, afirma:

\begin{abstract}
Para melhor situarmos o seu tratamento como tal, recorreremos à sua conceituação científica, quando as teorias a respeito o apresentam fundamentado no sentido dinâmico de modificação do status quo, na direção de configurações diferentes das atuais. A partir desse ponto, faz-se necessária a diferença entre o seu conceito e o de 'crescimento', podendo ambos incluir-se, sem qualquer confusão, na ideia de 'progresso'. O dado referencial, diferenciados, pode ser tomado, portanto, como ideia de 'equilíbrio', a ele prendendo-se a de 'desequilíbrio'. No 'crescimento', tem-se o 'equilíbrio' das relações entre os componentes do todo, podendo haver o seu aumento quantitativo ou qualitativo, porém mantidas as proporções dessas relações. No 'desenvolvimento', rompe-se tal 'equilíbrio', dá-se o 'desequilíbrio', modificam-se as proporções no sentido positivo. Se tal se verificasse em sentido negativo, teríamos o retrocesso, a recessão, embora também como forma de 'desequilíbrio', pois igualmente rompida com o status quo ante.
\end{abstract}

Portanto, a noção de vedação do retrocesso social está de maneira indissolúvel vinculada à noção de progresso, este, por sua vez, inerente ao crescimento. E, como não poderia ser distinto do quanto se vem afirmando, o desenvolvimento econômico de uma nação não poderá significar seu retrocesso social, desequilíbrio este não admitido pela ordem jurídica.

\footnotetext{
${ }^{248}$ SOUZA, Washington Peluso Albino de. Primeiras linhas de direito econômico. São Paulo: LTr, 1999, p. 404, apud REIS, Daniela Muradas. Op. Cit., p. 19.
} 
Da mesma forma, assim como o progresso econômico, a atividade legiferante deve vincular-se igualmente ao princípio em vista, de modo a proporcionar, juridicamente, a garantia dos avanços conquistados, para os quais não se admite, ademais, qualquer hipótese de eliminação dos padrões atingidos.

A nova hermenêutica Constitucional determina, portanto, que o princípio da proibição do retrocesso social tem igualmente caráter vinculativo com o póspositivismo, sendo possível reclamar por sua incidência em qualquer relação jurídica, invocando-o como norma protetora dos direitos sociais, em especial do direito do trabalho, instituto jurídico que mais vem sofrendo ataques desde o advento das políticas econômicas neoliberais.

Defende-se, portanto, que qualquer ato particular ou normativo ofensivo ao ordenamento Constitucional de promoção permanente dos direitos dos trabalhadores deve ser reprimido com afinco, de forma a garantir que as conquistas laborais durante séculos guerreadas não venha a se perder diante da satisfação de interesses econômicos escusos, os quais beneficiam apenas uma classe privilegiada.

Encontra-se como dever dos juristas, em todos os seus papeis de atuação, posições hierárquicas, cargos e funções, a manutenção de uma ordem social justa, baseada principalmente em sua vedação de retrocesso, repreendendo com vigor quaisquer atitudes que venham trazer prejuízos sociais ou ameaça às normas protetivas, bem como se esforcem no sentido de implementar em caráter ininterrupto os direitos fundamentais, mediante consistentes políticas normativas.

Cabe salientar, outrossim, que o princípio da proibição ao retrocesso, encontrando guarida como norma fundamental, tem seu conteúdo material hierarquicamente superior a qualquer ato normativo que lhe seja ulterior, uma vez que está, também, como direito fundamental, protegido sob o manto das cláusulas pétreas, atuando irrestritamente em todas as relações jurídicas que venham a ocorrer, sejam estas de âmbito privado ou público.

\subsubsection{O princípio justrabalhista da proteção e sua intersecção com o princípio da proibição ao retrocesso social}


O princípio da proibição ao retrocesso social, numa perspectiva de constante progresso, relaciona-se ao princípio da proteção ao trabalhador, coluna vertebral de todo o Direito do Trabalho, cabendo destacar que todos os institutos devem ser interpretados sempre à sua luz, enunciando o sentido teleológico de interpretação de todas as suas normas, bem ainda daquelas que são emprestadas de outros ramos, e agregadas à solução de seu conflitos.

Com lastro na dignidade da pessoa humana e no valor ínsito ao trabalho humano, o princípio tutelar enuncia ser a missão deste ramo jurídico a proteção do trabalhador, com a retificação jurídica da desigualdade socioeconômica inerente à relação entre capital e trabalho, fator agravado pela experiência de exploração do trabalho humano em épocas de escravidão indígena, negra e o trabalho assalariada do imigrante. Tal histórico é elemento preponderante para justificar a grande resistência social de implementação ideológica do direito do trabalho como elemento único de proteção dos direitos humanos nas relações trabalhistas, notadamente de sua ampliação.

O supracitado artigo $7^{\circ}$ denota o compromisso da ordem jurídica em promover, quantitativa e qualitativamente, o avanço das condições de pactuação da força de trabalho, bem como a garantia de que não serão estabelecidos recuos na situação sóciojurídica dos trabalhadores, onde se encontram, decerto, os princípios em voga.

O princípio protetor enaltece uma constante preocupação em proteger uma das partes, com o objetivo de alcançar-se uma igualdade verdadeira (e não apenas formal) entre as partes; vale dizer, promover ao máximo o combate às desigualdades inerentes existentes na relação de exploração do trabalho. Vale relembrar a lição do advogado e religioso Henri Lacordaire, que viveu no início do século XVIII, para quem "entre o fraco e o forte, entre o rico e o pobre, entre o patrão e o operário, é a liberdade que oprime e a lei que liberta".

O surgimento do direito do trabalho, como resposta aos séculos de exploração da mão de obra, reconheceu a existência de um desnível econômico real de condições entre as partes do contrato de trabalho, de modo que se inclinou, e não apenas formalmente, para uma compensação dessa desigualdade, criando-se, portanto, com outra 
desigualdade, como afirma o eminente Professor Américo Plá Rodrigues"249, "uma proteção jurídica favorável ao trabalhador".

Trata-se de tentar igualar cada vez mais as condições da luta pelo direito em que se encontra o economicamente desfavorável, a fim de se verem atenuadas as normas do direito privado individual, colocando-se como valor primordial o interesse social.

Desta forma, acredita o Prof. Jean L'Homme ${ }^{250}$ que “os privilégios (...) permitirão ao trabalhador recuperar, no terreno do direito, o que perdeu no terreno da economia, pois se percebe facilmente que o equilíbrio não é suficiente quando estabelecido unicamente no terreno jurídico", tentativa esta de se corrigir a outrora legítima desigualdade jurídica imposta.

Mister salientar, ademais, que o princípio em voga relaciona-se indistintamente com a proteção das normas de direito do trabalho, enunciando que deverá haver sempre interpretação da norma de forma favorável ao trabalhador.

Decorre esta interpretação, além das desigualdades históricas traçadas e que hoje formam a sociedade atual, a subordinação e dependência econômica do trabalhador ao seu empregador, sendo esta última, embora não necessária conceitualmente, apresentase na grande maioria dos casos, uma vez que somente labora para outrem, em troca de contraprestação financeira, aquele que se vê obrigado para sustentar a si ou a sua família; a lei, a fim de impedir abusos naturais provenientes dessa relação de dependência age no intento de serem impostos limites.

E, assim sendo, Daniela Reis ${ }^{251}$ parece sintetizar o princípio protetor da seguinte forma:

O princípio da norma mais favorável, cunhado na tradição justrabalhista, atua em dimensões distintas na ordem juslaboral (orientativa, interpretativa e hierarquizante) e enuncia que na criação, interpretação e aplicação da norma jurídica trabalhista deve-se considerar a melhoria das condições sociais do trabalhador. $\mathrm{Na}$

\footnotetext{
${ }^{249}$ PLÁ RODRIGUES, Américo. Princípios de Direito do Trabalho. 3 ed., Trad. Wagner Gilgio, São Paulo: LTr, 2004, p. 85.

${ }^{250}$ L'HOMME, Jean. El Derecho del Trabajo y su caráter unilateral, en la Ley”, 14.2.48, t. XLIX, p. 1003, apud PLÁ RODRIGUES, op. cit., p. 87.

${ }^{251}$ Op. Cit., p. 19-20.
} 
dimensão de fonte material, o princípio da norma mais favorável orienta o processo legislativo, estimulando a elaboração de normas que visem à elevação das condições sociais da classe trabalhadora.

Adequando o conceito supra, destaca-se também a normatividade do princípio protetor, que será aplicado independente da visualização de uma norma específica em um caso sub judice; o princípio será aplicado tal qual artigo de lei sempre que assim se necessite, de forma a vincular o intérprete tal qual um código o faz, transcendendo-se, portanto, seu caráter jusnaturalista outorgado pela autora.

O princípio protetor, outrossim, se expressa sob três formas distintas, que assim se desdobram:

a) A regra in dúbio pro operário. Critério que deve utilizar o juiz ou o intérprete para escolher, entre vários sentidos possíveis de uma norma, aquele que seja mais favorável ao trabalhador;

b) A regra da norma mais favorável determina que, no caso de haver mais de uma norma aplicável, deve-se optar por aquela que seja mais favorável, ainda que não seja a que corresponda aos critérios clássicos de hierarquia das normas; e

c) A regra da condição mais benéfica. Critério pelo qual a aplicação de uma nova norma trabalhista nunca deve servir para diminuir as condições mais favoráveis em que se encontrava um trabalhador.

Vislumbra-se, desta forma, que os esforços empreendidos pelos estudiosos do direito do trabalho voltaram-se para a consecução do fim da redução das desigualdades implementadas pela voraz exploração do trabalho humano pelo capital, o que, inclusive, direcionou suas regras interpretativas, e não apenas o conteúdo material das normas.

Arnaldo Süssekind, Délio Maranhão e Segadas Vianna ${ }^{252}$ sustentam que os fundamentos jurídico-políticos e sociológicos do princípio protetor geram outros mais:

d) O princípio da primazia da realidade, em razão do qual a relação objetiva evidenciada pelos fatos define a verdadeira relação

${ }^{252}$ SÜSSEKIND, Arnaldo Lopes et alii, Instituições de Direito do Trabalho - Vol. 1. São Paulo: LTr, 1997, p. 154. 
jurídica estipulada pelos contratantes, ainda que sob capa simulada, não correspondente à realidade;

e) Os princípios da integralidade e da intangibilidade do salário, que visam protegê-lo de descontos abusivos, preservar sua impenhorabilidade e assegurar-lhe posição privilegiada em caso de insolvência do empregador.

Todos os princípios vêm reforçar os fundamentos de que a proteção do trabalhador consiste-se em um fundamento maior da relação capital-trabalho, devendo haver a perfeita consonância entre um direito assegurado e a efetiva relação que se apresenta.

São tais princípios mutuamente aplicados, seja na interpretação da Lex ou em sua atividade legiferante, e mais ainda, na solução de um caso concreto, de forma a se garantir perenemente a existência de condições dignas ao trabalhador, em franco progresso de ampliação dos direitos sociais.

Deve-se destacar, neste ponto, que os princípios da norma mais favorável e o princípio da progressividade dos direitos sociais apresentam ponto de intersecção, relacionando-se intrinsecamente, embora, não se confundam.

Isto se deve em razão de que o conteúdo normativo do princípio da norma mais favorável desponta como importante instrumento de manutenção da civilização conquistada mediante o pacto social, atuando na preservação dos padrões sociais já assegurados pelo ordenamento jurídico estatal.

Pelo princípio da progressividade dos direitos humanos de caráter econômico, social e cultural, vincula-se a atividade legiferante nacional ao progresso ininterrupto das condições de proteção à pessoa humana na sua dimensão social, sendo juridicamente inviável, seja pela nova hermenêutica Constitucional ou pelo próprio conteúdo material do texto da Carta Magna, a eliminação dos padrões sociais já estabelecidos, sem a correspondente criação de um conjunto normativo compensatório e qualitativamente mais vantajoso, conforme determina o próprio princípio da norma mais favorável.

E, desta forma, apresentam como ponto de intersecção ambos os princípios o fato de que vinculam o Poder Legislativo e estabelecem obstáculo intransponível ao 
retrocesso sócio-jurídico do trabalhador, passando a ser a lei um verdadeiro "instrumento de ação concreta do Estado, tendo como método assecuratório de sua efetividade a promoção de determinadas ações pretendidas pela ordem jurídica ${ }^{253}$,.

E, da mesma forma, precede o princípio da proibição ao retrocesso o próprio princípio protetor, na visão de Daniela Muradas Reis, assim atuando:

É de se observar que tanto o princípio da norma mais favorável quanto
o princípio da progressividade dos direitos humanos sociais,
analisados sob o prisma da produção legislativa nacional, não
estabelecem a imutabilidade dos preceitos justrabalhistas; ao
contrário, determinam o constante aperfeiçoamento do ramo
juslaboral, a sua adaptação às novas necessidades sociais, sempre
encerrando o sentido de proteção, atávico ao Direito do Trabalho.

Logo, os princípios da norma mais favorável e da progressividade dos direitos humanos sociais traduzem um sentido normativo benéfico à pessoa humana, de forma que as alterações legislativas de ordem econômica ou social que, sob a perspectiva global, atendendo ao sentido dinâmico e positivo inerente à noção de progresso, não consubstanciam ofensa aos princípios basilares do Direito do Trabalho, devendo, por derradeiro, propiciar o desenvolvimento econômico também o mesmo desenvolvimento social propugnado.

$\mathrm{Na}$ hipótese, portanto, de se verificar, com as medidas econômicas, retrocesso social, devem estas ser repelidas do ordenamento jurídico, promovendo-se contra estas as ações judiciais constitucionais que visem desconstituir sua eficácia nas relações sociais. Não se pode olvidar, como o passado constitui de orientação ao futuro, que muitas das políticas econômicas do país foram malfadadas à sociedade, embora tenham a este trazido maior competitividade no mercado externo, pela implementação de novas tecnologias, mas que jamais foram questionadas, tais quais as privatizações acima mencionadas.

E, por assim ser, a ineficiência dos direitos sociais que até hoje se verificou, em conjunto com a ausência de políticas públicas voltadas ao amparo das vítimas das mazelas sociais, os direitos humanos reclamam uma tutela vigorosa, seja com a proteção

${ }^{253}$ STRECK, Lênio Luis. Hermenêutica jurídica e $(m)$ crise. Porto Alegre: Livraria do Advogado, 2003, 
do conteúdo normativo já conquistado e ainda, cumulativamente, com a promoção de direitos econômicos, sociais e culturais sempre progressiva, razão pela qual acerca destes direitos não se pode admitir o retrocesso.

Isto se deve em razão de que se deve ter como fundamento maior que "a consciência ética coletiva [...] amplia-se e aprofunda-se com o evolver da História. A exigência de condições sociais aptas a propiciar a realização de todas as virtualidades do ser humano é, assim, intensificada no tempo e traduz-se, necessariamente, pela formulação de novos direitos humanos. É esse movimento histórico de ampliação e aprofundamento que justifica o princípio da irreversibilidade dos direitos já declarados oficialmente, isto é, do conjunto de direitos fundamentais em vigor ${ }^{254}$,

p. 37-8, apud REIS, Daniela Muradas, p. 21.

${ }^{254}$ COMPARATO, Fábio Konder. A afirmação histórica dos direitos humanos. São Paulo: Saraiva, 1999, p. 53, apud REIS, Daniela Muradas, op. cit., p. 126-127. 


\section{CONSIDERAÇÕES FINAIS: SUBCONTRATAÇÃO COMO INSTRUMENTO DE VIOLAÇÃO AO PRINCÍPIO DA PROIBIÇÃO AO RETROCESSO SOCIAL}

Interessante indagar, a princípio, como um país historicamente caracterizado pela produção de bens primários, constituído, portanto, a partir de sua produção agrária se inseriria na produção de bens manufaturados, já que as potências capitalistas centrais o viam como mero fornecedor de matéria prima.

Certo é que o fim do tráfico negreiro (1850) e a abolição formal da escravidão (1888) constituíram-se de fatores importantes para a produção capitalista industrial, mediante a inserção do trabalho assalariado e, portanto, o alargamento do mercado consumidor em terras colonizadas.

A inserção da indústria no Brasil, conforme pode ser verificado, deu-se, classicamente, pelos modos fordista e taylorista de produção, sistemas científicos que determinavam o aumento da produtividade do trabalhador com o foco e a especialização em sua atividade, trabalhando de forma alienada ao processo de produção como um todo, para o fim de se evitar a perda de tempo.

Aliada à linha organizada, onde os conjuntos de peças e produtos passavam até sua finalização, referido modo de produção atingiu seu ápice, vindo a experimentar declínio a partir de 1974, após sua implementação pelo governo desenvolvimentista de Juscelino Kubitschek.

Tal modelo de produção apresentava rachaduras, demonstrando ser incapaz de sobreviver por si só, dados os limites de absorção da produção pelo restrito mercado consumidor, o inchaço da força de produção e a eclosão dos movimentos de luta dos trabalhadores dentro das fábricas, culminando na queda da taxa de lucros dos fabricantes e o acúmulo de bens em estoque.

Nos Estados Unidos e nos demais países capitalistas centrais, o sistema de produção fordista-taylorista vigorou fortemente até os anos 60 , quando começou a apresentar seus primeiros sintomas de crise, os mesmos acima enunciados. 
Ocorre, todavia, que a implementação das fábricas nestes territórios seguiu-se igualmente, pelo Estado, a implementação de políticas públicas que permitiam o crescimento industrial aliado à tranquilização do operariado revoltoso, criando-se, assim, o Welfare State, o qual funcionou como um fator de amortecimento das crises sociais que estariam por vir.

Com a crise do sistema produtivo e o recrudescimento do desemprego, o aumento da exploração no chão de fábrica, iniciou-se um movimento operário de questionamento, inclusive do que até então era fornecido pelo Estado do Bem-Estar Social - o que não ocorreu no Brasil.

Neste sentido, o capital novamente não deixaria de responder à crise, tratando logo de reorganizar seu ciclo produtivo. Nesse contexto se iniciou uma mutação no interior do padrão de acumulação, aliado à globalização, visando alternativas que conferissem maior dinamismo ao processo produtivo, que então dava claros sinais de esgotamento.

Gestou-se a transição do padrão taylorista e fordista anterior para as novas formas de acumulação flexibilizada.

O toyotismo, então, penetra, mescla-se ou mesmo substitui o padrão fordista dominante, em várias partes do capitalismo globalizado, tendo como forte aliado o sistema de computadores, utilizado em escala progressiva, o que faz tornar as antigas tecnologias completamente obsoletas, determinando, portanto, a sobrevivência ou a queda de uma organização empresarial.

Nota-se que em terras brasileiras a sociedade não experimentou as benesses do que o Welfare State pode proporcionar, como a assistência social. Logo, a já oprimida e massificada mão de obra operária do modelo fordista-taylorista de produção passou a ser marginalizada, excluída e ainda mais explorada com a transição de um modelo para outro.

Nesse contexto, o modelo japonês introduziu novas técnicas de produção, baseadas na liofilização (pulverização) organizativa, amparada na eliminação, 
transferência, terceirização e enxugamento de unidades produtivas ${ }^{255}$, do que se ressalta a subcontratação ora estudada.

A indústria toyotista, outrossim, disseminando o padrão enxuto da produção, o "lean production", inaugura o sistema horizontal, uma evidência que também se refletirá em novos padrões jurídicos de exploração da mão de obra, já que os direitos dos trabalhadores aparentam estar sendo flexibilizados.

A indústria outrora verticalizada passa ao novo padrão horizontal, reduzindo-se o âmbito de produção - o chão dá fábrica, propriamente dito - e estendendo-o às subcontratadas, às terceiras.

Neste sentido, a grande fábrica tende a se tornar simples gerenciadora, sem máquinas e sem operários. E a mesma razão que a faz "se enxugar" a impele a se desgarrar do território de origem, como se passasse de imóvel a móvel, sempre em busca de mão de obra barata, direitos flexíveis, sindicatos dóceis e políticas fiscais favoráveis.

A fábrica prioriza, portanto, o que é central (o "core business"), o que julga ser sua a especialidade no processo produtivo e transfere às empresas subcontratadas grande parte do que antes era produzido dentro de seu espaço produtivo. Esse fenômeno estende-se às subcontratadas, acarretando a expansão dos métodos e procedimentos da antiga fábrica para toda a rede de fabricantes, que passam a ser seus fornecedores.

Interessante demonstrar, como narrado, que, se durante a década de 1970, segundo Pochmann $(2000)^{256}$, no auge da expansão do emprego industrial, o Brasil chegou a possuir cerca de $20 \%$ do total dos empregos na indústria de transformação, 20 anos depois, a indústria de transformação absorvia menos de $13 \%$ do total da ocupação nacional.

\footnotetext{
${ }^{255}$ ANTUNES, Ricardo, Os sentidos do trabalho: Ensaio sobre a afirmação e a negação do trabalho. 2 ed., São Paulo: Boitempo, 2009, p. 51-52.

${ }^{256}$ POCHMANN, Márcio. Nova divisão internacional do trabalho e as ocupações no Brasil, 2000, apud ANTUNES, Ricardo e SILVA, Maria A. Moraes (orgs.). O avesso do trabalho, 2 ed., São Paulo: Expressão Popular, 2010, p. 21
} 
E, corroborando os dados estatísticos, para realizar a fábrica enxuta, o sistema toyotista de produção também se baseia na "fragmentação sistêmica"257" da indústria, constituindo as empresas redes, um dos exemplos mais notáveis do fenômeno da subcontratação.

As empresas se inserem um uma rede tão complexa de contratos e produção, que a principal acaba por se desfazer por completo de seus ativos fixos, propriedades e quaisquer bens, existindo apenas formalmente. Em contrapartida, possui margem de lucros estratosférica, conforme a grande patrocinadora esportiva Nike. Assim, ocorre a completa desverticalização total da empresa, criando uma rede de subcontratação com as empresas das quais passam a comprar o produto que antes produziam.

Em outras palavras, assistimos a transição da produção como meio de obtenção de lucro para um modelo capitalista parasitário e rentista, multiplicando-se a partir de si mesmo.

Como se destacou com a pesquisa empírica trazida a este trabalho ${ }^{258}$, observouse que quando se referem às vantagens da subcontratação, há similitude entre as justificativas apresentadas pelas empresas subcontratantes, as quais qualificam a subcontratação/terceirização como um procedimento que permite a centralização das tarefas, o foco na atividade que é importante. E o importante, conforme ressaltaram, é "manter as atividades que agreguem valor e não que agreguem custos": redução de investimentos em ativos, imóveis e a redução do custo da mão de obra.

Verifica-se que as empresas subcontratantes externalizam as atividades que se confundem com seu próprio "core business", notadamente em razão de não se estabelecer um método eficaz de distinção das atividades essenciais da indústria. Nesse sentido, poderia facilmente indagar-se se à indústria de confecção seu "core business" também não é o da montagem da peça de roupa, ou ainda, do seu bordado; mais ainda, se na indústria metalmecânica a montagem e produção dos eixos não constituiria sua atividade final ao mercado consumidor.

\footnotetext{
${ }^{257}$ ALVES, Giovanni, O novo (e precário) mundo do trabalho - reestruturação produtiva e crise do sindicalismo. Boitempo, 2010, p. 57.

${ }^{258}$ CARLEIAL, Liana. Redes industriais de subcontratação - em enfoque de sistema nacional de inovação, São Paulo: Hucitec, 2001.
} 
Conforme observado na pesquisa de Liana Carleial, a condição da maioria das empresas subcontradadas é precária; a pessoa que a representa não é seu sócio, tendo já sido empregado da empresa subcontratante, embora não mais tenha o mesmo salário; esta subcontratada depende integralmente do contrato que tem com a subcontratante, e, mão inversa, a subcontratante, em um determinado nicho de sua produção, depende também integralmente da produção da subcontratada, o que se justifica em razão da transferência total de sua produção para esta última ${ }^{259}$.

Como bem coloca o Prof. Souto Maior, tal medida (a subcontratação) resultou da necessidade do capital em tornar nebulosa a identificação da relação de emprego alastrando a linha de produção para além dos limites físicos da fábrica.

E, nesse contexto, o processo produtivo acabou por ser "pulverizado em diversas unidades, fornecendo a aparência de que cada uma das unidades seja a realização de uma atividade empresarial específica. ${ }^{260,}$

Em conjunto ao trabalho da pesquisadora Liana Carleial, também pudemos apreender o estudo empírico dos impactos causados pelas mudanças ocasionadas pela reestruturação produtiva, desde os anos 1980, na indústria de calçados de Franca-SP, e quais os impactos dessas transformações sobre o conjunto da força de trabalho ali empregada.

Alerta a pesquisadora Vera Lúcia Navarro ${ }^{261}$, conforme já ponderado, que, independentemente das variações ascendentes e decrescentes do volume da produção ao longo da década de 1986-1996, a indústria calçadista francana extinguiu pelo menos 16.500 postos de trabalho nesse período, em sua enorme maioria em decorrência não da incorporação de maquinaria mais desenvolvida ao setor, e, sim, da adoção de estratégias de gerenciamento da produção pelas indústrias, vale dizer, a substituição de postos de trabalho por empresas subcontratadas, e até mesmo de pessoas intermediadas por uma suposta legítima pessoa jurídica.

\footnotetext{
${ }^{259}$ Conforme se destacou no item 1.1, quando se analisa a subcontratante "C", do ramo da eletroeletrônica, e sua relação com a subcontratada "C1".

${ }^{260}$ MAIOR, Jorge Luiz Souto. Curso de direito do trabalho - A Relação de Emprego, Vol. II, São Paulo, LTr: 2008, p. 137.

${ }^{261}$ NAVARRO, Vera Lúcia. A reestruturação produtiva na indústria de calçados de couro em Franca $(S P)$, in ANTUNES, Ricardo. Op. Cit., 2010, p. 74.
} 
Ao mesmo tempo em que se reduziram drasticamente os postos de trabalho nas indústrias, proliferaram diversas modalidades de trabalho em domicílio e nas bancas ${ }^{262}$.

Igualmente, a reportagem da revista Época, produzida por Ana Aranha e denominada "Cerco às senzalas da moda" 263 trouxe a realidade das grandes confecções nacionais que se utilizam da subcontratação para a produção de suas peças.

O que se denota é que a subcontratação pode tratar-se de um meio perverso do desmantelamento da proteção social causada pelo capital, uma vez que se retira da esfera de proteção legal o trabalhador contratado pela subcontratada, alijando-o por completo da classe trabalhadora e, muitas vezes, da própria noção de dignidade, como no caso acima.

Portanto, na perspectiva da luta de classes, a terceirização é um processo enfraquecedor, debilitante da classe operária, relegando-a à massa de manobra política. Seus objetivos constitucionais sufragados pela melhoria contínua das condições sociais de deixam de ser cumpridos, contribuindo para a precarização das condições de trabalho, haja vista a completa ausência de resistência da classe frente ao corte salarial e de benefícios.

Desta feita, observamos também que o descumprimento das normas do direito do trabalho pode, igualmente, tratar-se de dano social, conforme se destacou o artigo publicado pelo Prof. Jorge Luiz Souto Maior ${ }^{264}$ :

O descumprimento deliberado do direito do trabalho pode ser considerado uma questão de interesse social, motivando a intervenção do Ministério Público, na medida em que, principalmente no que tange às regras de segurança e medicina do trabalho, esta atitude gera grande custo social, representado pelo acréscimo vertiginoso de doenças no trabalho e acidentes do trabalho, além de poder ser visto como uma forma de se estabelecer uma concorrência desleal entre as empresas, incentivando o "dumping” social numa perspectiva interna.

\footnotetext{
262 Bancas: denominação dada às unidades produtivas prestadoras de serviço para as indústrias de calçados de Franca, especializadas em realizar determinadas etapas de confecção de calçados. Ex.: banca de pesponto, banca de corte, banca de chanfração, banca de ponteação etc. Na região produtora de calçados do Rio Grande do Sul, essas unidades produtivas são denominadas "ateliers". NAVARRO, Vera Lúcia, Op. Cit., p. 123.

${ }^{263}$ Revista Época. ed. no 673/2011, Ed. Globo, 11/04/2012.

${ }^{264}$ MAIOR, Jorge Luiz Souto. A Fúria. In: Revista LTr, São Paulo, Ano 66, no 11, p. 1287-1309.
} 
E, por incentivar a concorrência desleal, concorre para a prática do dano social, proveniente do "dumping"; desagregando-se por completo o sistema protetivo, as empresas passam a auferir maior lucro, de forma indevida, prejudicando a malha social como um todo, seja a classe trabalhadora, seja o mercado consumidor, seja a própria cadeia produtiva.

Nesse sentido, por constituir-se um abuso de direito, o abuso do direito da livre iniciativa e da exploração de atividade empresarial, imprescindível se faz a reparação, nos termos do quanto representam os arts. 187 e 927, do Código Civil, de forma objetiva, isto é, sema a necessidade de aferição de culpa empresarial, que é presumida neste caso.

E a reparação não só visa a proteção à coletividade de trabalhadores, mas também, como já ressaltado, aos demais empregadores. Aquele empregador que, valendo-se das agressões aos direitos do trabalhador, consegue auferir maior lucro, obtém indevida vantagem econômica com relação aos demais, que cumprem a legislação. Desta forma, estes últimos, verificando uma verdadeira vantagem no descumprimento dos direitos dos trabalhadores, igualmente pendem à prática de tal atitude.

Certo é que o vilipêndio aos direitos do trabalhador até se chegar ao cúmulo do dano social decorre de um ranço histórico extremamente doloroso, proveniente da escravidão, que, em termos históricos, fora abolida há pouquíssimo tempo. Referida modalidade de exploração do trabalho humano trouxe ao Brasil prejuízos de toda a sorte, mais evidenciados na estrutura social e na valorização do trabalho humano, como apontou brilhantemente o Prof. Jorge Luiz Souto Maior ${ }^{265}$.

E, neste sentido, o direito do trabalho, nascido para a proteção dessa classe, acaba sendo desprezado e considerado pela aristocracia, inclusive, como resultado indevido da intervenção do Estado, combatido até hoje pelos neoliberais. Seu objetivo é manter as diferenças entre as classes como modo eficiente de exploração do trabalho; tais fatores, cumpre destacar, são responsáveis pela letargia do Estado na elaboração dos textos de lei voltados à regulação da relação de trabalho no Brasil.

\footnotetext{
${ }^{265}$ MAIOR, Jorge Luiz Souto. O direito do trabalho como instrumento de justiça social. São Paulo:
} LTr, 2000, p. 62-63. 
A lógica do novo modelo de exploração do trabalho, notadamente da reestruturação produtiva e da flexibilização das normas de proteção ao trabalho é precarização, de descarte desse meio de produção. Segundo a OIT, há perto de um bilhão de desempregados no mundo, sendo 40 milhões encontrados nos países $\operatorname{avançados}^{266}$, o que corrobora a gana e a fúria com que o capital avança sobre o trabalho. De outro modo, é interessante destacar que esse dado somente demonstra que as práticas flexibilizadoras do trabalho adotadas somente vieram a rechaçar a ideia de que se deveria flexibilizar para se continuar empregando.

Igualmente, neste mesmo sentido, conforme demonstrado ao longo desse trabalho, aponta o economista Joseph Stiglitz, pesquisando o desenvolvimento mundial e a pobreza, que, como reflexo das novas condições capitalistas da globalização, o número atual de pessoas vivendo na pobreza atualmente aumentou em quase 100 milhões ${ }^{267}$. Isto ocorreu ao mesmo tempo em que a renda mundial aumentou em média $2,5 \%$ ao ano.

O fato perverso é que um Estado fraco, mantendo em suas estruturas as mesmas oligarquias liberais de outrora, tende a chancelar referidas práticas, corroborando as mazelas sociais da época da colonização, de forma irreversível.

Ocorre, todavia, que inobstante a história capitalista demonstrar a derrocada do sistema de proteção conferido pelas leis trabalhistas em nome de poderes escusos, impossível olvidar que as garantias outorgadas pelo art. $7^{\circ}$ da Carta Magna jamais poderão ser objeto de emenda constitucional ou lei (nisso entenda-se a normatividade heterônoma e autônoma do direito do trabalho), que as tente abolir ou flexibilizar, uma vez que o artigo 60 do texto constitucional expressamente declara tratarem-se tais garantias de cláusulas pétreas.

Neste sentido, imprescindível é a lição do Prof. Paulo Bonavides ${ }^{268}$ :

\footnotetext{
${ }^{266}$ VIANA, Marcio Tulio. A proteção social do trabalhador no mundo globalizado, In: PIMENTA, José Roberto Freire et alii. Direito do Trabalho: evolução, crise, perspectivas. São Paulo: LTr, 2004, p. 163 267 STIGLITZ, Joseph E. Globalization and Its Discontants. New York/London, 2003, p. 6, apud PIOVESAN, Flávia. Direito ao trabalho e a proteção dos direitos sociais nos planos internacional e constitucional, In PIOVESAN, Flávia e CARVALHO, Luciana Paula Vaz de (orgs.). Direitos Humanos e Direito do Trabalho, São Paulo: Atlas, 2010, p. 13.

${ }^{268}$ BONAVIDES, Paulo. Curso de direito constitucional, 25 ed., São Paulo, Malheiros: 2009, p. 657.
} 
Tanto a lei ordinária como a emenda à Constituição que afetarem, abolirem ou suprimirem a essência protetora dos direitos sociais, jacente na índole, espírito e natureza de nosso ordenamento maior, padecem irremissivelmente da eiva da inconstitucionalidade, e como inconstitucionais devem ser declaradas por juízes e tribunais, que só assim farão, qual lhes incumbe, a guarda bem-sucedida e eficaz da Constituição.

Neste sentido, é indispensável e iminente a necessidade de tutela do Estado para o fim de se efetivar a proteção a tais direitos, o que ocorre, de acordo com o quanto analisou esta pesquisadora, apenas com a firme intervenção do Poder Judiciário.

E, assim sendo, conforme salienta o Prof. Souto Maior, a intervenção estatal como forma de garantir direitos não se trata de um autoritarismo, "mas do reconhecimento de que as regras do mercado livre já nos levaram e não se inibirão de nos levar, novamente, aos horrores sociais do período pós-revolução industrial e pósguerras. $^{269,}$

Desta forma, como se colocou como proposta de estudo, observou-se que as novas formas de exploração do trabalho, em especial a subcontratação, constitui-se de forma de precarização do trabalho e de patente instrumento de ofensa à legislação posta e, notadamente, à Constituição da República.

Neste sentido, o direito, como necessário instrumento de contenção das lides e de apaziguamento social, não pode permanecer inerte diante das afrontas diretas à Constituição e a à própria legislação vigente.

E, desta forma, é que se chama à responsabilidade o capital, mediante a coerção do Estado, que analisará, mediante o poder judiciário, a ocorrência de tais ofensas legais e danos - abstratos e concretos - e então aplicará a Justiça.

Para tanto, analisou-se as diversas possibilidades com as quais pode o prisma jurídico lidar com a situação fática apresentada, partindo-se sempre da perspectiva de reparação patrimonial ao quanto causado ao trabalhador quando se fala em subcontratação.

${ }^{269}$ MAIOR, Jorge Luiz Souto, Op. Cit., 2000, p. 279. 
Inicialmente, demonstrou-se o reconhecimento da responsabilidade subsidiária do tomador de serviços de maneira irrestrita, mas a discussão acerca do que se tratava como atividade-meio ou fim mostra-se inócua, uma vez que sua definição traz um ranço eminentemente subjetivo.

Isto porque deve-se supor, como premissa inicial embasada no art. $3^{\circ}$, da CLT, que a relação de emprego se estabelece pela natureza não eventual da prestação de serviços e não pela sua ligação direta ou indireta com o objeto central das atividades desenvolvidas. Nesses termos, o critério instituído pela Súmula 331, estabelecendo permissão jurisprudencial para prática da terceirização, por meio da divisão em atividade-fim ou atividade-meio, contraria dispositivo legal $\operatorname{expresso~}^{270}$.

Não é demais afirmar, nesse sentido, que o critério atribuído pelo TST acaba por gerar distorções na interpretação do direito, distanciando-o cada vez mais da realidade, o que significa dizer que se trata de uma tentativa do distanciamento do capital para com os meios de produção.

Entendemos, portanto, que os critérios estabelecidos para a configuração da responsabilidade subsidiária não devem ser aplicados à subcontratação, uma vez que o entendimento sobre o que se trata de atividade-fim ou meio pode ser controverso, gerando injustiça na apreciação do caso: pode-se, nesse contexto, entender que a atividade subcontratada tampouco se trata de atividade fim ou meio, mas que exista mera relação de consumo, o que gerará a declaração da inexistência de qualquer responsabilidade da empresa subcontratante.

Tal fator, ademais, fora analisado na presente pesquisa e, de acordo com os parâmetros fáticos colocados, notadamente diante do histórico da pulverização industrial ocorrida nos últimos 20 anos, não há como se admitir que a empresa subcontratante reste isenta de qualquer responsabilidade quando tenha se beneficiado diretamente da mão de obra do trabalhador.

270 LEITÃO, Tábata Gomes Macedo de. A terceirização no contexto de eficácia dos direitos fundamentais. Dissertação de Mestrado. São Paulo: Faculdade de Direito da Universidade de São Paulo, 2012. 
O caso NESTLÉ é paradigmático no sentido de se demonstrar o que se colocou no Capítulo 1, ou seja, na tentativa de ver-se livre dos meios de produção, o capital externaliza suas atividades produtivas, exigindo, para tanto, que lhe seja exclusiva a prestação dos serviços (nesse caso, a facção), fulminando-lhe de morte, contudo, ao fim do contrato. Trata-se da pseudo-empresa referida pela pesquisadora Liana Carleial.

De acordo com a análise do direito e dos fatos apresentados, a subcontratação, ora se verificando mediante o contrato de facção, ora como rede de empresas, prestando trabalho à pessoa jurídica com exclusividade, de atividade que lhe é permanente, gera a responsabilidade direta da empresa subcontratante, ou principal com os trabalhadores desta última, inclusive seus sócios e demais alto-empregados, que em tese estariam dispensados do registro em CTPS.

Observou-se, ainda, que não raro há o trabalho explorando o trabalho. Conforme aludido, ex-empregados, agora referidos como empresários ou gestores, passam a coordenar o trabalho de outros trabalhadores, tudo em benefício da empresa principal, oferecendo-lhe o produto acabado para que o explore economicamente no mercado.

A ineficiência do requisito trazido pela Súmula 331 (atividade fim/meio) deve ser encarada em conjunto, portanto, com a exclusividade da produção de determinado bem para se alcançar tal fim. Insuficiente, portanto, o critério da Súmula 331, do TST, pelo que não há que se falar em aplicação da responsabilidade subsidiária.

Não é demais lembrar que a responsabilidade subsidiária, conforme se verificará adiante, é notavelmente inconstitucional, porquanto contraria dispositivo expresso de lei (art. $\left.3^{\circ}, \mathrm{CLT}\right)$, além de colidir diretamente com os princípios protetivos do direito do trabalho e o princípio da proibição ao retrocesso social.

Contudo, sob outra vertente deve ser analisada a subcontratação, também.

Em não se verificando a exclusividade da subcontratada, mas ainda assim a permanência da atividade subcontratada de produção, nada impede a responsabilização solidária entre ambas as empresas no que tange aos créditos trabalhistas dos empregados da subcontratada, diante da inequívoca aplicação do $\S 2^{\circ}$, do art. $2^{\circ}$, da CLT, mediante a interpretação conferida pelo Prof. Marcio Tulio Viana; hipótese do grupo de empresas, 
de modo que tal regra se aplicaria, inclusive, às indústrias de auto-peças e as montadoras de veículos, que se pulverizam em um condomínio industrial, onde se verifica legítima relação de coordenação (Prof. Paulo Eduardo Vieira de Oliveira).

Certo que se tratam de personalidades jurídicas distintas, mas a subcontratação, como meio patente de externalização de atividade produtiva outrora componente da empresa subcontratante, lhe fornece bens que diretamente irão compor seu produto final, de modo que a mão de obra da subcontratada de forma igual, ou seja, diretamente, beneficia a subcontratante, laborando na atividade que lhe é permanente e essencial.

Deve-se eliminar os pressupostos da responsabilidade subsidiária, vez que esta não tem amparo legal e tampouco se sustenta mediante uma coerente construção doutrinária e jurisprudencial. Ataca, ademais, os princípios constitucionais.

Sua análise a partir do ponto de vista jurídico, portanto, é de um contrato civil ou comercial, nos termos do Código Civil, celebrado entre duas empresas, onde uma delas se compromete a fornecer (subcontratada), conforme destacado elo economista e pesquisador Éolo Marques Pagnani, peças, componentes, subconjuntos ou conjuntos, e que se agregarão ao produto final da outra (subcontratante) mediante pagamento.

De modo que, precarizando a relação de trabalho mediante a flagrante ingerência econômica na atividade produtiva da subcontratada, obtém indevidamente vantagens financeiras, devendo responsabilizar-se paritariamente à empresa que apenas e tão somente empregou formalmente aqueles empregados. Por tais razões, a existência do contrato de facção tal qual seu conceito - entrega de produtos acabados - não exclui a necessária aplicação da responsabilidade patrimonial da empresa subcontratante.

E essa proteção não se trata meramente em aplicar a responsabilidade subsidiária ou solidária às empresas envolvidas mas, em um caso de exploração exclusiva de uma empresa, consoante visto pelo exemplo NESTLÉ x OFICINA DO CACAU, das "fast shops" ou das oficinas de calçados, é de efetivar as normas sociais mediante a declaração do vínculo de emprego entre todos os empregados desta última empresa com a empresa principal, inclusive dos sócios proprietários que, mesmo constituídos como gestores de uma pessoa jurídica, também ostentam, na verdade, a função de empregados, com o diferencial de que assumem o risco do empreendimento. 
Igualmente, coloca o Professor Souto Maior ${ }^{271}$, em cujo trecho de sua obra se observa:

\begin{abstract}
"Nas situações, portanto, em que, por exemplo, costureiras trabalhem em suas residências para uma outra pessoa [realidade inclusive estudada no presente trabalho], ou empresa, que "compra" daquela o produto acabado para vendê-lo, livremente, no mercado [verdadeiro contrato de facção], há de se reconhecer que tais costureiras são empregadas da empresa final e que o intermediário, mesmo constituído como pessoa jurídica, também o é, com um aspecto ainda pior que é o de ter sido utilizado como empregador aparente, tendo, inclusive, que arcar com parcela do risco econômico que era próprio da grande empresa."
\end{abstract}

Certo é que nesses casos onde reina a exclusividade, patente é a existência da subordinação econômica das empresas e, também, da estudada subordinação estrutural/reticular, teoria que revisita o tradicional conceito de subordinação jurídica.

Isto porque, em tempos modernos, o avanço da sociedade industrial proporcionou desenvolvimento ao capitalismo de modo a suscitar um avanço tecnológico (notadamente diante do teletrabalho e dos sofisticados meios de comunicação e logística) que igualmente se sucedeu nas tentativas de elisão de sua responsabilidade pelo risco da atividade empreendida.

Tornou-se, portanto, difícil a tarefa de, muitas vezes, identificar o próprio empregador, muitas porque o empregado, ainda que formalmente respondendo a uma empresa, está inserido na dinâmica organizacional e estrutural de outra, daí advindo, então, a subordinação estrutural.

Como pondera Lorena Vasconcelos Porto, a subordinação deve ser verificada "pela simples integração da prestação laborativa nos fins da empresa. Havendo a inserção dos serviços prestados pelo trabalhador nos objetivos perseguidos pelo tomador, configura-se a subordinação."272

\footnotetext{
${ }^{271}$ MAIOR, Jorge Luiz Souto. Relação de emprego e direito do trabalho, São Paulo: LTr, 2008, p. 138.

${ }^{272}$ PORTO, Lorena Vasconcelos. A subordinação no contrato de trabalho - uma releitura necessária. São Paulo: LTr, 2009, p. 250.
} 
Nesse contexto, poderá se observar, à guisa dos julgados que isentam de qualquer responsabilidade a empresa principal da rede produtiva ou subcontratante do contrato de facção, que há evidente desvirtuamento conceitual da relação de emprego, mormente em razão da "crescente concepção do trabalhador (supostamente) autônomo, mas econômica e habitualmente dependente de uma mesma rede produtiva. ${ }^{273,}$

A subordinação jurídica, portanto, não emerge apenas do uso da voz do empregador, do supervisor ou do capataz direcionada diretamente ao empregado. Ela pode se formar a partir dos múltiplos agentes econômicos coordenados pela unidade central, de modo silencioso.

A subordinação jurídica pode ser então 'reticular', também nesse sentido e através de instrumentos jurídicos de associação empresária, onde nenhuma atividade econômica especializada é desenvolvida pelo suposto empregador, que se envolve na produção de um determinado resultado pactuado com a unidade central. Suposto, não porque em verdade não o seja, mas por não ser o único empregador.

Desta forma, imputando a todos os componentes da rede econômica (reticular, portanto), não se verificaria a necessidade de se perquirir a existência de fraude, de terceirização de atividade-fim ou da mera intermediação de mão de obra, consoante aponta a Súmula 331, do TST.

Interessante destacar, neste viés de falta de regulamentação, que no Congresso Nacional, conforme noticiado e estudado, existem diversos projetos legislativos em trâmite a fim de se dispor, mediante texto legal, o instituto da terceirização.

Daqueles que foram analisados, somente se comprometem efetivamente com os prospectos constitucionais o Projeto de Lei $\mathrm{n}^{\circ}$ 1.621/2007 (ANEXO 7), de autoria do Deputado Federal Vicentinho (PT-SP), porquanto determina a responsabilidade solidária da empresa subcontratante com relação aos créditos dos trabalhadores da empresa subcontrada, de maneira incondicional, bastando demonstrar a prestação de serviços entre as empresas e, por óbvio, o labor daquele determinado trabalhador.

\footnotetext{
${ }^{273}$ MENDES, Marcus Menezes Barberino \& CHAVES JUNIOR, José Eduardo de Resende. Subordinação estrutural-reticular e alienidade. In: Revista do Tribunal Regional do Trabalho da $15^{\mathrm{a}}$ Região, Campinas, SP, n. 32, jan/jun 2008, p. 136.
} 
À falta de dispositivos positivados que possam regulamentar referido instituto, possível é, também, afora as teorias acima apresentadas, analisarmos o direito comparado como forma de solução ao conflito proveniente das hipóteses de subcontratação.

Conforme explanado, os padrões do Mercosul são as referências metodológicas utilizadas em razão da conformação econômica de tais países, em conjunto às semelhanças históricas que apresentam com o Brasil.

Diante da possibilidade de integração dos ordenamentos mediante a aplicação do art. $8^{\circ}$, da CLT, entendemos que nem toda a legislação apresentada verifica-se consonante com os objetivos da República, bem ainda aos princípios protetores eleitos.

A base analógica fática relativa à terceirização é a mesma; observa-se a relação triangular e a presença de uma pessoa natural que lhes presta serviços.

Nos ordenamentos analisados, verifica-se a positivação no sentido de se admitir, como regra, a responsabilidade solidária das empresas principais, sendo esta, contudo, mitigada e limitada à subsidiária nas hipóteses em que demonstrarem o exercício do seu poder-dever de fiscalização.

Contudo, de acordo com nossa análise, sob a perspectiva da proteção do que cada um dos ordenamentos alienígenas representa, notadamente diante do que dispõe o art. $7^{\circ}$ da Constituição da República, acreditamos que revela-se mais compatível com o quanto defendido neste estudo é a aplicação do vínculo de emprego de acordo com o que prevê o ordenamento argentino, uma vez que o art. 26 da LCT dispõe sobre o conceito de empregador plural.

Sua interpretação conjunta aos artigos 690 e seguintes da lei civil levam à conclusão de que, nos casos de descentralização produtiva, deverá ser declarado o vínculo de emprego com a empresa principal, sendo, ainda, todas as demais empresas solidariamente responsáveis pelos créditos apurados.

Na Espanha, há interessante dicotomia entre os conceitos de terceirização e subcontratação, tendo a doutrina dispensado tratamento diverso à hipótese de descentralização produtiva tal qual ora estudamos. 
Segundo a jurista María Ángeles Alcalá Díaz ${ }^{274}$, há a cooperação entre indústrias para a produção e comercialização de produtos como estratégia de expansão dos negócios. Tal fenômeno se caracteriza:

\begin{abstract}
“(...) Bajo la denominación de subcontratación de la producción se incluyen las decisiones estratégicas de organización de la empresa en las que total o parcialmente se trasladan a otras empresas externas la fabricación del producto bajo la marca y según las características y métodos definidos por la empresa descentralizada."
\end{abstract}

Verifica-se, portanto, identidade no conceito de subcontratação acima para com a qual intencionamos conferir, de maneira que, ainda dentro deste contexto, há outra subdivisão - as empresas subcontratadas que possuem autonomia financeira e aquelas que são economicamente dependentes da empresa principal, ou subcontratante. Em ambos os casos, decerto, observa-se a independência formal entre as empresas.

No primeiro caso, as alianças horizontais, denota-se, geralmente, a intenção de comum desenvolvimento econômico entre as empresas, de modo que, para unir-se e garantir competitividade no mercado, grandes empresas empreendem uma união de esforços para operar no mesmo setor econômico, implementando um seccionamento de atividades com fins à especialização e à competitividade, proporcionando ao seu mercado consumidor produtos de tecnologia de ponta.

Geralmente se verifica tal engajamento nas atividades de informática, automação e eletrônica, que geralmente demandam altos investimentos e demonstram altos padrões de desenvolvimento tecnológico e de inovação, que assim serão dispostos no mercado.

Nesta espécie, em suma, não há precarização das condições de trabalho e tampouco se verifica a necessidade de reprimir tais técnicas de administração. Entretanto, como se verificou alhures, ainda que não haja qualquer intuito fraudulento, é mister deixar claro que se as empresas se unem para um fim comum, todas do grupo se beneficiam por meio do esforço conjunto de todos os empregados, devendo todas ser tratadas como empresas componentes do mesmo grupo empresarial, respondendo solidariamente por eventual inadimplemento de verba trabalhista.

${ }^{274}$ DÍAZ, María Ángeles Alcalá. Técnicas jurídico-contratuales de descentralización empresarial (p. 95- 
De outro modo, observa a doutrina espanhola que também se denotam as alianças verticais, ou piramidais.

Neste caso, há o nítido controle exercido pela grande empresa sobre as demais, estabelecendo relação de dependência e subordinação. Há, ademais, desigualdade entre as empresas, sendo que aquela que está no comando impõe condições de produção e do desenvolvimento dos aspectos empresariais das demais, em uma patente relação de exclusividade.

Assim como ora defendemos, o enfoque jurídico deve ser diversamente dispensado a uma e a outra situação.

$\mathrm{O}$ art. 42, do Estatuto dos Trabalhadores prevê, contudo, que deverá haver responsabilidade solidária quando se verifique a externalização de atividades próprias da empresa principal. Trata-se do mesmo entrave enfrentado pelos juristas brasileiros, uma vez que a definição da aplicação de um ou de outro dispositivo dependerá do conceito de "atividade própria", assim como aqui, o de "atividade-fim".

A atual doutrina vem conferindo à referida expressão interpretação extensiva, de modo a se coadunar com os princípios protetivos do direito do trabalho. Igualmente como entendemos para o caso brasileiro, a aplicação da responsabilidade solidária se dá apenas de forma residual, aos casos, portanto, das alianças horizontais.

Analisado o contexto fático e jurídico da subcontratação de acordo com os recursos dispostos no ordenamento, observamos como a subcontratação se verifica no campo dos fatos, e quais os reflexos estes proporcionam à sociedade.

Interessante destacar, mediante nossa pesquisa também teórica, que os fatos da subcontratação agridem os princípios e, portanto, o dever-ser jurídico, o qual tem como fim a busca incessante da justiça social e do apaziguamento dos conflitos sociais.

Certo é que o direito do trabalho, como se vem explorando, é norteado por princípios próprios, derivados do princípio protetor.

162). In: GAETA, Lorenzo y MOYA, Rosario Gallardo (orgs.). Los empresarios complejos: un reto para el Derecho del Trabajo. 1 ed., España: Editorial Bomarzo, 2010, p. 102. 
A nova hermenêutica constitucional determina que os princípios desçam do patamar meramente referencial e interpretativo a que estavam fadados e integrem-se, hodiernamente, à legislação protetiva, exercendo sua função tal qual norma fosse, uma vez que o ordenamento positivado não se mostra suficiente a solucionar as questões sociais postas sob a ótica do judiciário, cada vez mais complexas.

Fala-se, portanto, de neoconstitucionalismo, de nova hermenêutica constitucional ou do pós-positivismo, superando-se a dualidade do positivismo/jusnaturalismo, e da necessidade do Estado em reconhecer ao homem os direitos que já lhe são inatos.

Não se verifica, portanto, a previsão normativa de tantos comportamentos que a sociedade moderna apresenta - assim como a subcontratação - , de modo que os conflitos acabam por persistir com soluções ineficientes e muitas vezes injustas, sem qualquer respaldo científico ou que se contradizem.

Igualmente, a ineficiência das políticas públicas quanto às normas de direito social, em conjunto a um Estado cada vez menos presente, baseado em uma ideologia neoliberal de base, de cortes em investimentos sociais, marcam a necessidade da passagem entre uma exegese constitucional e outra.

Trata-se da correção de um padrão político que esteve presente nos 500 anos de existência do Brasil, onde os direitos estiveram baseados em um padrão eivado de ideais liberais. A determinação dos princípios como normas vem, portanto, em um sentido de correção de desigualdades sociais, e o chamamento do Estado aos deveres que hoje são impingidos a cumprir.

Abandona-se, portanto, o perfil autoritário e aristocrático dos modelos anteriores para se viver a democracia promulgada pela Assembleia Constituinte, instituindo-se um Estado Social, jamais antes visto no país. Para tanto, contudo, também deixa-se de lado as o mito das normas meramente programáticas para garantir a cada cidadão o direito estabelecido no texto Constitucional.

Trata-se, por conseguinte, de dar à Constituição e, portanto, ao Estado brasileiro, a força que merecem, não deixando nas mãos do legislador infra-constitucional o destino da nação, uma vez que tais leis, muitas vezes, esvaziam o caráter normativo e 
teleológico da própria Constituição. No direito do trabalho são exemplos as leis flexibilizadoras, como a do trabalho temporário (que erroneamente foi recepcionada) e a Súmula 331, do TST, que colidem frontalmente ao princípio da proibição ao retrocesso social.

Os direitos sociais detêm, portanto, exigibilidade e acionabilidade, baseados em postulados hermenêuticos científicos, e não na política anteriormente dirigida ao seu caráter programático. Ainda que sob o apelo do ativismo judicial, deve o judiciário fazer valer as normas constitucionais, não cabendo mais, na sociedade, a cegueira aos direitos conferidos ao cidadão, ranço histórico da colonização.

Nesse escopo interpretativo, observamos da Constituição da República, também, o princípio da proibição ao retrocesso social.

Nesta perspectiva, a violação do princípio por si só não corresponderia à violação de uma norma em especial, mas corresponderia à violação de todo um sistema, de uma ordem fundante.

Cabe dizer que serão os princípios, portanto, dotados de sanções distintas daquelas que se aplicam às normas, porquanto a ofensa é muito maior, transcendendo a um código ou ao texto constitucional, mas afetando toda a ordem jurídica estabelecida. Neste caso, o ato, se emanado de autoridade, é eivado de nulidade, porquanto incompatível com todo o sistema jurídico posto.

Reconhece-se, conforme o jurista espanhol F. de Castro demonstra, a função de ser "fundamento da ordem jurídica, com eficácia derrogatória e diretiva".

Não é demais admitir, portanto, que a nova hermenêutica Constitucional trouxe ao Direito uma fase de hegemonia e preeminência dos princípios, de forma que os conflitos não resolvidos com pauta na lei posta, o serão, com a mesma força, com os princípios, dado que, como finaliza Bonavides, são estes "a viga-mestra do sistema, o esteio da legitimidade constitucional, o penhor da constitucionalidade das regras de uma Constituição" 275 .

${ }^{275}$ Idem, p. 294. 
Com isso, pode-se depreender que os artigos constitucionais entrelaçam-se, sendo a Constituição um texto alinhavado no sentido de se cumprir os objetivos estabelecidos pela República em seu art. $3^{\circ}$ e 170 , notadamente de justiça social e solidariedade, com vistas à redução progressiva das desigualdades sociais.

Desta forma, está imposta ao legislador infraconstitucional a impossibilidade de adotar regimes legais que importem no retrocesso de proteção aos direitos fundamentais. Igualmente, lhe é proibido deixar de regulamentar, em sede legislativa, uma norma constitucional que lhe estabeleça tal dever, cabendo, inclusive, os recursos judiciais para que se faça valer tal direito, a exemplo do mandado de injunção (art. $5^{\circ}$, inciso LXXI) e da ação direta de inconstitucionalidade por omissão (art. 103, § $2^{\circ}$ ), bem como de outros recursos judiciais.

Neste sentido, Felipe Derbli ${ }^{276}$, proeminente procurador e professor carioca que explora a contento o princípio em voga, estabelece:

Uma vez alcançado determinado patamar de concretização de uma norma constitucional definidora de direito social, através de lei, será defeso ao legislador suprimir ou reduzir essa concretização, sem que, ao menos, crie algum mecanismo equivalente ou substituto.

Cabe dizer que, portanto, o conteúdo material estabelecido pela Constituição da República quanto aos direitos e garantias fundamentais é imutável; seu núcleo de proteção a tais direitos não pode ser atingido, ainda que reflexamente, por uma lei que venha a suprimir, reduzir ou limitar seus efeitos, sob pena de ser declarada inconstitucional.

Neste particular, não seria demais afirmar que as normas flexibilizadoras do direito do trabalho, por conta da incompatibilidade substancial que lhes é ínsita, são contrárias ao princípio de vedação do retrocesso, de forma que, invariavelmente, se não esbarrassem nos obstáculos políticos para tanto, segundo a autêntica hermenêutica proposta, estariam eivadas completamente pelo vício da inconstitucionalidade em razão do seu conteúdo material, devendo ser repelidas pelo ordenamento jurídico brasileiro.

${ }^{276}$ DERBLI, Felipe. O princípio da proibição de retrocesso social na Constituição de 1988. Rio de Janeiro: Renovar, 2007, p. 223. 
Em suma, conforme ressalta Derbli, o "princípio em questão veda ao legislador subtrair da norma constitucional definidora de direitos sociais o grau de concretização já alcançado, prejudicando a sua exequibilidade. Vale dizer, haverá retrocesso social quando o legislador, comissiva e arbitrariamente, retornar a um estado correlato a uma primitiva omissão inconstitucional ou reduzir o grau de concretização de uma norma definidora de direito social; onde não houver imposição legiferante - e, portanto, for mais fluida a delimitação das raias da liberdade de conformação do legislador (o que ocorre no caso das normas constitucionais programáticas), não se poderá falar propriamente em proibição de retrocesso social" ${ }^{277}$, exceto se ato normativo posterior assim lhe ofender, de modo a contrariar as finalidades constitucionais expressamente expostas.

Assumem, portanto, como colocam os juristas portugueses Gomes Canotilho ${ }^{278} \mathrm{e}$ Vital Moreira, os direitos fundamentais sociais "a condição de verdadeiros direitos de defesa contra medidas de cunho retrocessivo, que tenham por objeto a sua destruição ou redução".

O princípio da proibição ao retrocesso social, numa perspectiva de constante progresso, relaciona-se ao princípio da proteção ao trabalhador, coluna vertebral de todo o Direito do Trabalho, cabendo destacar que todos os institutos devem ser interpretados sempre à sua luz, enunciando o sentido teleológico de interpretação de todas as suas normas, bem ainda daquelas que são emprestadas de outros ramos, e agregadas à solução de seus conflitos.

E, assim sendo, Daniela Reis ${ }^{279}$ parece sintetizar o princípio protetor da seguinte forma:

O princípio da norma mais favorável, cunhado na tradição justrabalhista, atua em dimensões distintas na ordem juslaboral (orientativa, interpretativa e hierarquizante) e enuncia que na criação, interpretação e aplicação da norma jurídica trabalhista deve-se considerar a melhoria das condições sociais do trabalhador. $\mathrm{Na}$ dimensão de fonte material, o princípio da norma mais favorável

\footnotetext{
${ }^{277}$ Idem, p. 240.

${ }^{278}$ CANOTILHO, J.J. Gomes. Direito Constitucional e Teoria da Constituição, p. 474-5, apud SARLET, Op. Cit., p. 440.

${ }^{279}$ Op. Cit., p. 19-20.
} 
orienta o processo legislativo, estimulando a elaboração de normas que visem à elevação das condições sociais da classe trabalhadora.

Adequando o conceito supra, destaca-se também a normatividade do princípio protetor, que será aplicado independente da visualização de uma norma específica em um caso sub judice; o princípio será aplicado tal qual artigo de lei sempre que assim se necessite, de forma a vincular o intérprete tal qual um código o faz, transcendendo-se, portanto, seu caráter jusnaturalista outorgado pela autora.

Isto se deve em razão de que se deve ter como fundamento maior que "a consciência ética coletiva [...] amplia-se e aprofunda-se com o evolver da História. A exigência de condições sociais aptas a propiciar a realização de todas as virtualidades do ser humano é, assim, intensificada no tempo e traduz-se, necessariamente, pela formulação de novos direitos humanos. É esse movimento histórico de ampliação e aprofundamento que justifica o princípio da irreversibilidade dos direitos já declarados oficialmente, isto é, do conjunto de direitos fundamentais em vigor ${ }^{280, "}$

Neste comento, interessante destacar, a título de consideração final, que a subcontratação é um fenômeno real, isto é, um fato concreto. Verifica-se no campo da realidade, campo sobre o qual incidem as normas jurídicas, nos termos das doutrinas jusfilosóficas mais proeminentes ${ }^{281}$.

Com efeito, não há como afastar a percepção de que a subcontratação é prática que viola flagrantemente normas principiológicas que, embora se achem naquela esfera a que denominam "dever-ser", são a base primeira das demais normas do ordenamento positivo, do próprio conjunto normativo do Direito do Trabalho. Mais do que isso, a subcontratação viola o lastro normativo de todo o Direito - e não só do trabalhista - na medida em que confronta princípios de direitos humanos, caracterizando verdadeiro retrocesso nesse aspecto.

Desta feita, somente pode-se admitir a subcontratação em sua modalidade horizontal, garantindo-se, ademais, que todos os empregados serão amparados em seus

${ }^{280}$ COMPARATO, Fábio Konder. A afirmação histórica dos direitos humanos. São Paulo: Saraiva, 1999, p. 53, apud REIS, Daniela Muradas, op. cit., p. 126-127.

${ }^{281}$ A exemplo da Teoria Tridimensional do Direito, de Miguel Reale, sendo que é indubitável que o campo de atuação do direito é a realidade, ainda que as normas figurem naquilo a que chamam "dever ser". 
direitos a contento, mediante a correta aplicação da responsabilidade solidária. Do contrario, trata-se de verdadeiro instrumento de violação ao princípio da proibição ao retrocesso social. 


\section{Livros}

ALVES, Giovanni. O novo (e precário) mundo do trabalho - reestruturação produtiva e crise do sindicalismo. Boitempo, 2010.

ANTUNES, Ricardo. Adeus ao trabalho?, 7 ed., São Paulo: Cortez, 2000.

O caracol e sua concha, 1 ed., São Paulo: Boitempo, 2011.

Os sentidos do trabalho: Ensaio sobre a afirmação e a negação

do trabalho. $2^{\text {a }}$ ed., São Paulo: Boitempo, 2009.

ANTUNES, Ricardo e SILVA, Maria A. Moraes (orgs.). O avesso do trabalho. 2 ed., São Paulo: Expressão Popular, 2010.

BAUMAN, Zygmunt. Modernidade Líquida. Rio de Janeiro: Zahar, 2000.

BARROS, Alice Monteiro de. Curso de direito do trabalho. 6 ed., São Paulo: LTr, 2009.

BARROSO, Luís Roberto. O direito constitucional e a efetividade de suas normas, 5 ed., Rio de Janeiro: Renovar, 2001.

BIHR, Alain. Da grande noite à alternativa: o movimento operário europeu em crise. (trad. Wanda Caldeira Brant) 2 ed., São Paulo, Boitempo Editorial: 2010.

BOBBIO, Norberto. Teoria da Norma Jurídica. São Paulo: Edipro, 2001.

BOBBIO, Norberto. Teoria do Ordenamento Jurídico. 10 ed., Brasília: Editora Universidade de Brasília, 1999.

BONAVIDES, Paulo. Curso de direito constitucional, 25 ed., São Paulo, Malheiros: 2009.

CARLEIAL, Liana. Redes industriais de subcontratação - em enfoque de sistema nacional de inovação, São Paulo: Hucitec, 2001. 
CATHARINO, José Martins. Compêndio Universitário de Direito do Trabalho, vol. I, São Paulo: Jurídica e Universitária, 1972.

DELGUE, Juan Raso. La contratación atípica del trabajo. Montevideo: Editorial Amalio M. Fernández, 2003.

DERBLI, Felipe. O princípio da proibição de retrocesso social na Constituição de 1988. Rio de Janeiro: Renovar, 2007.

DINIZ, Maria Helena. Compêndio de Introdução à Ciência do Direito. 20 ed., São Paulo: Saraiva, 2009.

DRUCK, Maria da Graça. Terceirização: (Des)Fordizando a fábrica - um estudo do complexo petroquímico da Bahia. Tese de Doutoramento, UNICAMP, Campinas: 1995.

FERRAZ JR., Tércio Sampaio. Introdução ao Estudo do Direito, 3 ed., São Paulo: Atlas, 2001.

FURTADO, Celso. Formação econômica do Brasil. 34 ed., São Paulo, Companhia das Letras: 2007.

GARMENDIA ARIGÓN, Mario. Eficacia práctica de las normas laborales. Montevideo: FCU, 2005.

GARMENDIA, Mario \& GAUTHIER, Gustavo. Tercerizaciones - Análisis de las leyes $n^{o} 18.099$ y 18.251 y su aplicación jurisprudencial. 2 ed., Montevideo: Fundación de Cultura Universitaria, 2012.

GORZ, André. Metamorfoses do Trabalho: Busca do Sentido, Crítica da razão econômica, trad. Ana Montoia, Ed. Annablume, 1988.

KOSHIBA, Luiz e PEREIRA, Denise F. Manzi. História do Brasil, 6 ed., São Paulo: Atual, 1993.

LIKER, Jeffrey K. e MEIER, David. O modelo Toyota: Manual de Aplicação. Trad. Lene Belon Ribeiro, Porto Alegre: Bookman, 2007. 
MAIOR, Jorge Luiz Souto. Curso de direito do trabalho - Teoria Geral, Vol. I, Parte I, São Paulo: LTr, 2011.

Curso de direito do trabalho - A Relação de Emprego,

Vol. II, São Paulo: LTr, 2008.

Relação de emprego e direito do trabalho, São Paulo: LTr,

2008.

MAIOR, Jorge Luiz Souto e CORREIA, Marcus Orione Gonçalves (org.). Curso de Direito do Trabalho - Vol. II, Coleção Pedro Vidal Neto, São Paulo, LTr: 2008.

MARTINS, Sérgio Pinto. Flexibilização das condições de trabalho. 3 ed., São Paulo, Atlas: 2004.

MEDINA, David Montoya. Trabajo en contratas y protección de los trabajadores. Valencia: Tirant Lo Blanch, 2004.

MIÑO, Irene Rojas. Subcontratación laboral, suministro de trabajo y cesión ilegal de trabajadores. Chile: Abeledo Perrot Legal Publishing, 2011.

MORAES FILHO, Evaristo de. Apontamentos de direito operário. 2 ed., Edição comemorativa do centenário do Autor, LTr, São Paulo: 1971.

OLIVEIRA, Paulo Eduardo Vieira. $O$ dano social no direito do trabalho, 2 ed., São Paulo: LTr, 2010.

OLIVEIRA, Francisco de. Crítica à razão dualista/O ornitorrinco. São Paulo: Boitempo, 2011.

PASTORE, José. Flexibilização dos Mercados de Trabalho e Contratação Coletiva, São Paulo, LTr: 1995.

PLÁ RODRIGUES, Américo. Princípios de Direito do Trabalho. 3 ed., Trad. Wagner Gilgio, São Paulo: LTr, 2004.

PIOVESAN, Flávia e CARVALHO, Luciana Paula Vaz de (orgs.). Direitos Humanos e Direito do Trabalho, São Paulo: Atlas, 2010. 
PORTO, Lorena Vasconcelos. A subordinação no contrato de trabalho - uma releitura necessária. São Paulo: LTr, 2009.

REALE, Miguel. Lições Preliminares de Direito. 27 ed., São Paulo: Saraiva, 2007.

REIS, Daniela Muradas. O princípio da vedação do retrocesso no Direito do Trabalho, São Paulo: LTr, 2010.

ROSENBAUM, Jorge e CASTELLO, Alejandro. Régimen Jurídico de la Subcontratación e Intermediación Laboral. Montevidéo: Fundación de Cultura Universitária, 2007.

SALOMÃO FILHO, Calixto et alii, Concentração, estrutura e desigualdade: As origens coloniais da pobreza e da má distribuição de renda. São Paulo: Editado por Instituto de Direito do Comércio Internacional e Desenvolvimento (IDCID), 2008.

SANDRONI, Paulo. Dicionário de Economia, Série Os Economistas, Abril Cultural, 1985.

SARLET, Ingo Wolfgang. A eficácia dos direitos fundamentais - uma teoria geral dos direitos fundamentais na perspectiva constitucional, 10 ed., Porto Alegre, Ed. Livraria do Advogado: 2009.

STRECK, Lenio Luiz. Jurisdição constitucional e hermenêutica. 2 ed., Rio de Janeiro: Forense, 2004.

SÜSSEKIND, Arnaldo. Direito constitucional do trabalho, 2 ed., Rio de Janeiro, Renovar:2001.

SÜSSEKIND, Arnaldo Lopes et alii, Instituições de Direito do Trabalho - Vol. 1. São Paulo: LTr, 1997.

VIANA, Márcio Túlio. A proteção social do trabalhador no mundo globalizado, In: PIMENTA, José Roberto Freire et alii. Direito do Trabalho: evolução, crise, perspectivas. São Paulo: LTr, 2004.

\section{Artigos}


ALVAREZ, Eduardo. Artículo: Tercerización, descentralización productiva y derecho del trabajo, In: Revista Argentina - Derecho del Trabajo - ISSN 2250-8074 - Año I $n^{\circ} 1$ - Mayo 2012, Editorial Ministerio de Justicia y Derechos Humanos de la Nación.

BARROSO, Luís Roberto. Neoconstitucionalismo e constitucionalização do direito -o triunfo tardio do direito constitucional no Brasil. In: Revista da Escola da Magistratura do Tribunal Regional do Trabalho da $2^{\text {a }}$ Região, Ano 2, no 2 (set.2007), São Paulo, Semestral, Revista Oficial do TRT da $2^{\text {a }}$ Região - São Paulo, p. 11-52.

CADIDÉ, Iracema Mazetto. A subordinação estrutural no contexto da terceirização. In: Revista LTr Legislação do Trabalho, Ano 74, nº 05, Maio/2010.

CIAMPA, Gustavo. Artículo: Apuntes para una reforma del art. 30. LCT, In: Revista Argentina - Derecho del Trabajo - ISSN 2250-8074 - Año I - nº 1 - Mayo 2012, Editorial Ministerio de Justicia y Derechos Humanos de la Nación.

CONFALONIERI, Juan A. Artículo: Transformaciones productivas e identificación del empleador. El empleador plural o múltiple, In: Revista Argentina - Derecho del Trabajo - ISSN 2250-8074 - Año I - nº 1 - Mayo 2012, Editorial Ministerio de Justicia y Derechos Humanos de la Nación.

DAROCA, Elena Desdentado. La responsabilidad del empresario en la descentralización productiva. Un análisis crítico del art. 42 del estatuto de los trabajadores (p. 185-212). In: GAETA, Lorenzo y MOYA, Rosario Gallardo (orgs.). Los empresarios complejos: un reto para el Derecho del Trabajo. 1 ed., España: Editorial Bomarzo, 2010.

DÍAZ, María Ángeles Alcalá. Técnicas jurídico-contratuales de descentralización empresarial (p. 95-162). In: GAETA, Lorenzo y MOYA, Rosario Gallardo (orgs.). Los empresarios complejos: un reto para el Derecho del Trabajo. 1 ed., España: Editorial Bomarzo, 2010.

FERRARI, Irany. Terceirização - contrato de facção - responsabilidade subsidiária. In: LTr Suplemento Trabalhista, São Paulo, 2004, Ano 40, nº 110/04. 
FERRARI, Irany. Contratos de facção e terceirização - distinção para efeito de responsabilidade. In: LTr Suplemento Trabalhista, São Paulo, 2010, Ano 46, nº 036/10.

KROST, Oscar. Contrato de facção: fundamentos da responsabilidade da contratante por créditos trabalhistas dos empregados da contratada. In: Justiça do Trabalho, Ano 24 - no 287 - Novembro de 2007. HS Editora, pp. 28-35.

LOFFREDO, Antonio. O novo cenário da descentralização produtiva, In: GAETA, Lorenzo y MOYA, Rosario Gallardo (Dir.). Los empresários complejos: un reto para el Derecho del Trabajo, Editorial Bomarzo S.L., Albacete, Espanã, 2010.

MAIOR, Jorge Luiz Souto. A Fúria. In: Revista LTr, São Paulo, Ano 66, nº 11, p. $1287-$ 1309.

O Dano Sociale sua Reparação. In: Revista IOB Trabalhista e Previdenciária, Ano XIX, nº 225, março/2008. p.58-72.

MENDES, Marcus Menezes Barberino \& CHAVES JUNIOR, José Eduardo de Resende. Subordinação estrutural-reticular e alienidade. In: Revista do Tribunal Regional do Trabalho da 15ª Região, Campinas, SP, n. 32, jan/jun 2008.

\section{Dissertações e Teses}

CUNHA, Tadeu Henrique Lopes da. Terceirização e seus efeitos sobre os direitos do trabalhador no ordenamento jurídico brasileiro. Dissertação de Mestrado. São Paulo: Faculdade de Direito da Universidade de São Paulo, 2007.

LEITÃO, Tábata Gomes Macedo de. A terceirização no contexto de eficácia dos direitos fundamentais. Dissertação de Mestrado. São Paulo: Faculdade de Direito da Universidade de São Paulo, 2012.

PAGNANI, Éolo Marques. A subcontratação na pequena e média empresa industrial. Campinas. UNICAMP. Tese de Doutoramento, 1976.

\section{Sítios da internet}

www.ilo.org.br 
www.planalto.gov.br

www.tst.jus.br

www.trt2.jus.br

www.trt15.jus.br

www.trt3.jus.br

www.anamatra.org.br

www.camara.gov.br

www.losrecursoshumanos.com

http://www.ugt.es/DatoBasico/estatutodelostrabajadoresactualizado.pdf

http://infoleg.mecon.gov.ar - Ley de Contrato de Trabajo Argentina

www.dt.gob.cl - Código del Trabajo de Chile

www.mtss.gub.uy - Ley de Tercerización de Uruguay

www.ugt.es - Estatuto de los Trabajores de España 
ANEXOS 
ANEXO 1 - Contrato Nestlé e Oficina do Cacau 


\section{CONTRATO DE INDUSTRIALIZACC̃OO E FORNECIMENTO SOB ENCOMENDA DE PRODUTOS E OUTRAS AVENCAS}

Pelo presente instrumento particular e na melhor forma de direito, de um lado

NESTLÉ BRASIL LTDA., com sede na cidade de São Paulo (SP), à Avenida das Nações Unidas, n. ${ }^{\circ} 12.495$ - Brooklin Novo, inscrita no CNPJ sob o $n .^{\circ} 60.409 .075 / 0001-52$, neste ato representada na forma do seu Contrato Social, doravante denominada simplesmente "NESTLÉ", e, de outro lado,

OFICINA DO CACAU IND. E COM DE GENEROS ALIMENTICIOS LTDA.(EPP), com sede na cidade de Jacareí/SP, à Rod. Geraldo Scavone, $n^{\circ} 2.300$ - bloco G-29 do condomínio empresarial Jardim Califórnia, inscrita no CNPJ sob o n. $05036119 / 0001-38$, neste ato representada na forma de seus atos constitutivos, doravante denominada simplesmente "OFICINA DO CACAU",

\section{CONSIDERANDO QUE:}

a) A NESTLÉ é uma empresa que se dedica à fabricação e comercialização de diversos produtos alimentícios ;

b) A NESTLÉ deseja contratar a "OFICINA DO CACAU", para que esta última the industrialize e forneça sob encomenda algumas variedades de produtos alimentícios, com base nas receitas, fórmulas e especificaçōes de propriedade ou desenvolvidas para NESTLÉ (doravante somente os "Produtos") ;

c) A "OFICINA DO CACAU"é uma sociedade que conta com as instalações, capacidade técnica e industrial, bem como com os recursos humanos necessários para industrializar e fornecer sob encomenda os Produtos à NESTLÉ e assim cumprir com as obrigações estabelecidas no presente Contrato ;

Resolvem as Partes celebrar o presente Contrato, mediante as seguintes cláusulas e condições que reciprocamente estipulam, outorgam e aceitam, a saber:

\section{CLÁUSULA PRIMEIRA - OBJETO E PRODUTOS}

1.1 A "OFICINA DO CACAU" se obriga a proporcionar à NESTLÉ os serviços consistentes na industrialização (fabricação e/ou acondicionamento), fornecimento e entregá dos Produtos que NESTLÉ vier a the encomendar com base neste Contrato, nas quantidades e dentro da periodicidade que the sejam requeridas por esta última, serviços estes que serão executados nas instalaçōes industriais da "OFICINA DO CACAU" situadas na, à Rod. Geraldo Scavone, $n^{\circ} 2.300$ - bloco G-29 do condomínio empresarial Jardim Califórnia, cidade de Jacarei Estado de São Paulo (doravante a "Fábrica") e segundo o mecanismo previsto na cláusula segunda deste Contrato.

1.2 "OFICINA DO CACAU" se obriga a levar a cabo as atividades de industrialização (fabricação e/ou acondicionamento, dependendo do Projeto), fornecimento e entrega dos Produtos de conformidade com as instrúções, especificaçōes e receitas aplicáveis, pertencentes a ou desenvolvidas para o Grupo Nestlé, dos quais a 
NESTLÉ é a legítima proprietária ou licenciada exclusiva para o seu uso no Brasil (doravante os "Conhecimentos"), Conhecimentos estes que se encontrarão especificados e serão detalhados em cada projeto que NESTLÉ encomende à "OFICINA DO CACAU" (doravante somente os "Projetos"), conforme previsto na Cláusula Segunda.

1.2.1 Poderão existir Projetos em que estejam incluídos nos Conhecimentos passados por NESTLÉ à "OFICINA DO CACAU" "Know-how" de NESTLÉ e/ou processos de industrializaçăo específicos que somente NESTLÉ detenha a tecnologia. Nestes casos, fica desde já estabelecido que "OFICINA DO CACAU" irá dar a tais elementos o mesmo tratamento exigido neste Contrato aos outros que obrigatoriamente sempre compóem os Conhecimentos, em especial aqueles tratamentos exigidos pelas Cláusulas Quarta, Décima Primeira e Décima Quinta, parágrafo 15.3.

1.3 De acordo com cada Projeto encomendado por NESTLÉ, os Conhecimentos serão transmitidos pela NESTLÉ à "OFICINA DO CACAU", com a finalidade de que os Produtos sejam industrializados, fornecidos e entregues em linha com os requerimentos técnicos e industriais da NESTLÉ.

1.3.1 A NESTLÉ poderá alterar os Conhecimentos e demàis especificaçōes técnicas exigidas para qualquer dos Produtos, à qualquer tempo, mediante comunicação expressa à "OFICINA DO CACAU", com 30 (trinta) dias de antecedência.

1.3.2 Fica estabelecido que, na hipótese dos Conhecimentos e/ou outras exigências de padrão de qualidade de NESTLÉ serem mais rígidos do que aqueles estabelecidos na legislação vigente, prevalecerão sempre aqueles fixados por NESTLÉ.

\section{CLÁUSULA SEGUNDA - PROJETOS}

2.1 Durante a vigência deste contrato, sempre e quando NESTLÉ requeira que "OFICINA DO CACAU" the industrialize algum dos Produtos, deverá entregar a esta um Projeto, o qual deverá trazer os respectivos Conhecimentos do Produto encomendado e deverá seguir o modelo previsto no Anexo A deste Contrato.

2.2 O Anexo A mencionado no parágrafo anterior estabelece o modelo que deverá ser seguido por NESTLÉ para a formalização da encomenda de um Projeto à "OFICINA DO CACAU", bem como quais as informaçōes pertinentes que deverão ser fornecidas para a industrialização, fornecimento e entrega do Produto nele envolvido, quais sejam:

(a) Os Conhecimentos;

(b) O procedimento de liberação dos Produtos, incluindo o Plano de Monitoramento. Microbiológico;

(c) O rendimento e os indices de perdas; 
(d) A programação de abastecimento, com clara definição dos insumos que deverão ser fornecidos por NESTLÉ e aqueles que deverão ser fornecidos pela "OFICINA DO CACAU"; e

(e) As condições comerciais e fiscais acordadas, tais como preço e respectivos critérios e periodicidade de revisão/reajustes, os procedimentos fiscais a serem aplicados e as condições e/ou preços aplicáveis para as perdas de Insumos acima das variações aceitas por NESTLÉ.

2.3 A cada Projeto que NESTLÉ deseje encomendar à "OFICINA DO CACAU" deverá fazê-lo com base no mencionado Anexo $A$, incluindo todas as informações $\mathrm{e}$ condiçoes nele previstas, que deveräo ter sido previamente acordadas com "OFICINA DO CACAU". O Projeto será considerado parte do presente Contrato, estando sujeito a seus termos e condições, desde que devidamente firmado pelos representantes definidos e indicados por ambas as partes, previamente à data em que se pretenda iniciar a industrialização do Produto nele envolvido.

2.4 A menos que as Partes estabeleçam em forma expressa e especifica qualquer variação à forma definida no referido Anexo A para a encomenda de um Projeto, a NESTLÉ não estará obrigada a apresentar Projetos para industrialização e fornecimento de Produtos à "OFICINA DO CACAU" de forma distinta ao previsto em tal Anexo A.

\section{CLÁUSULA TERCEIRA - INSUMOS E MATERIAL DE EMBALAGEM (doravante os "Insumos")}

\subsection{Abastecimento dos Insumos}

Para a devida industrialização e fornecimento dos Produtos pela "OFICINA DO CACAU" à NESTLÉ, os insumos deverão ser adquiridos e entregues na "OFICINA DO CACAU" conforme Anexo A, em linha com o estabelecido no respectivo Projeto.

Neste sentido, como a programação de abastecimento e todo o respectivo planejamento estarão acordados e definidos no Projeto, NESTLÉ e/ou "OFICINA DO CACAU", conforme oportunamente neste sentido, deverão providenciar o abastecimento dos Insumos de forma a garantir que o programa de produção possa ser cumprido sem prejuizos para nenhuma das partes.

\subsection{Conservação dos Insumos}

A "OFICINA DO CACAU" conservará os Insumos em instalaçōes adequadas na Fábrica, garantindo perante a NESTLÉ que tais instalações possuem as condições pertinentes para manter a qualidade e características de tais Insumos.

\subsection{Registro}

A "OFICINA DO CACAU" manterá um registro dos Insumos utilizados, bem como dos procedimentos e controles levados a cabo para cada lote de industrialização dos Produtos, incluindo o controle efetivo dos Insumos não utilizados e suas perdas, documentação esta que deverá estar disponivel para verificação caso seja requerida pela NESTLÉ, de modo a possibilitar que NESTLÉ tenha condiçoes de rastrear os Insumos necessários para a industrialização dos Produtos e gerir o respectivo abastecimento. 


\subsection{Procedimentos de recepção e armazenagem dos Insumos}

A "OFICINA DO CACAU" deverá examinar os Insumos no momento do seu recebimento e antes da sua utilização na industrialização dos Produtos, tendo a responsabilidade final pela sua aceitação ou devolução. Neste sentido, deverá devolver os Insumos que não cumpram com (i) as especificações e padrões estabelecidos no Projeto respectivo do Produto a que o Insumo se refira; (ii) us demais termos e condições deste Contrato; e (iii) as leis, disposições e regulamentos aplicáveis.

\subsection{Perdas das Matérias-Primas}

Com relação às perdas dos Insumos, cada Projeto estabelecerá os rendimentos exigidos por NESTLÉ e os índices de perda que serão por esta tolerados, de onde as Partes acordam que, no processo de industrializaçāo dos Produtos, todas as perdas acima dos niveis aceitos por NESTLÉ deverão ser suportadas pela "OFICINA DO CACAU", não podendo esta incluir tais perdas no custo de industrialização e fornecimento dos Produtos, de acordo com as condições aplicáveis para tais perdas, que também estarão definidas no Projeto.

CLÁUSULA QUARTA - ESPECIFICAC̄ÕES, PROCESSOS DE INDUSTRIALIZACCÃOO, SISTEMAS DE GARANTIA DA QUALIDADE E INSPECÕES

4.1 Industrialização dos Produtos

a) A "OFICINA DO CACAU" fica obrigada e se compromete a industrializar e entregar os. Produtos, seguindo para cada uma de tais atividades as Boas Práticas de Manufatura, Segurança e Higiene aplicáveis à indústria relacionada com a industrialização dos Produtos, observando, em especial, todos os requisitos do Nivel 1 de prioridade do NQS (Nestlé Quality System) de NESTLE, cujo conteúdo se anexa ao presente Contrato por meio de seu Anexo B, e os Conhecimentos que the forem entregues juntamente aos Projetos. Fica acordado entre as partes que os custos inerentes a auditorias de qualidade (através de empresas terceiras de consultorias aprovadas por NESTLÉ) requeridas por NESTLÉ para o cumprimento com o referido NQS serão arcados total e exclusivamente por "OFICINA DO CACAU".

b) A "OFICINA DO CACAU" cumprirá em forma estrita com os preceitos contidos no Anexo B e com os Conhecimentos, com a finalidade de obter é garantir a segurança e qualidade que os Produtos exigem para serem comercializados por NESTLE junto ao público consumidor.

c) A "OFICINA DO CACAU" deverá contar com a aprovação prévia da NESTLÉ para realizar qualquer alteração nas atividades de industrialização e controle de qualidade dos Produtos na Fábrica.

\subsection{Garantia da Qualidade e Garantia sobre os Produtos}

a) A "OFICINA DO CACAU" assume total responsabilidade por todos os aspectos relacionados com a qualidade dos Produtos e de seu processo de industrialização e entrega, responsabilidade esta que se estenderá até a efetiva aceitação dos Produtos por parte de NESTLÉ, sob os termos e condições deste Contrato.

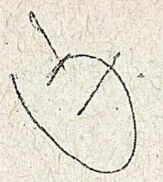


b) As análises sensoriais, organolépticas e microbiológicas dos Produtos serão realizadas de conformidade com os procedimentos e métodos previstos na Cláusula Sexta do presente instrumento (doravante as "Análises"), a fim de verificar e. assegurar o cumprimento dos Conhecimentos e demais especificaçōes contempladas neste Contrato.

4.3 Inspeções

a) A NESTLÉ terá a faculdade de contar com pelo menos um representante em forma permanente na Fábrica durante a industrialização e armazenagem dos Produtos, a fim de que possa observar e inspecionar todas as atividades levadas a cabo pela "OFICINA DO CACAU" durante tais processos, atividades estas mencionadas a seguir em forma enunciativa mas não limitativa: recebimento e armazenagem dos Insumos e industrialização e entrega dos Produtos.

b) Neste mesmo sentido, fica assegurado à NESTLÉ o direito de, por meio de preposto devidamente credenciado, ter acesso às instalações da Fábrica durante o horário comercial ou a qualquer momento que se faça necessário, devendo tal preposto designado por NESTLÉ ser sempre acompanhado de um funcionário designado pela "OFICINA DO CACAU".

\section{CLÁUSULA QUINTA -ENTREGA, TRANSPORTE E ARMAZENAGEM DOS PRODUTOS}

\subsection{Entrega}

A entrega dos Produtos pela "OFICINA DO CACAU" à NESTLÉ será considerada realizada no momento em que o lote ou lotes correspondentes tenham sido retirados por NESTLÉ na Fábrica, a qual deverá ser feita na modalidade FOB ("Free on Board"), sendo a "OFICINA DQ CACAU". responsável pela conservação e manipulação dos Produtos ate esse momento.

Fica acordado entre as partes que a entrega acima mencionada não implica em liberação e aceitação do Produto por parte de NESTLÉ, uma vez que o lote ou lotes entregues. serão transportados por NESTLÉ para destino definido por NESTLÉ, onde serão armazenados enquanto aguardam a realização das Análises e o decurso do prazo para poderem ser considerados liberados $c$ accitos por NESTLÉ, conforme previsto na Cláusula Sexta a seguir.

\subsection{Transporte}

A NESTLÉ será responsável pelo transporte dos Produtos da Fábrica ao seus destinos por ela definidos, sendo responsável pelos danos ou avarias ocasionados nos Produtos. durante o referido transporte.

\subsection{Armazenagem}

Assim que ocorra a industrialização de um ou mais lotes dos Produtos, estes deverão ser expedidos para o seu destina definido por NESTLÉ, conforme previsto nesta cláusula, não havendo portanto armazenamento dos Produtos na Fábrica.

Na hipótese de, por qualquer motivo, haver a necessidade de que os Produtos sejam. 
armazenados na Fábrica enquanto aguardam o seu respectivo transporte, a "OFICINA DO CACAU" se obriga a efetuar tal armazenagem em local adequado e devidamente preparado para tal firm na Fábrica, o qual poderá ser inspecionado pela NESTLÉ, com a finalidade de supervisionar as condições de armazenagem dos Produtos até a sua efetiva entrega.

Uma vez entregues por "OFICINA DO CACAU" e transportados por NESTLÉ, os Produtos serão armazenados por NESTLÉ em local apropriado, onde aguardarão a realização das Análises e a posterior liberaçāo, conforme previsto na Cláusula Sexta a seguir.

\section{CLÁUSULA SEXTA - ANÁLISES, LIBERACÃO E ACEITACC̃̃O DOS PRODUTOS}

6.1 As partes acordam que para a liberação e aceitação por NESTLÉ de qualquer lote de Produtos industrializado e entregue por "OFICINA DO CACAU", deverão ser observados os procedimentos de Análises estabelecidos na presente cláusula.

\subsection{As Análises}

(i) Para cada lote de Produto industrializado e entregue pela "OFICINA DO CACAU" à NESTLÉ, será enviado um documento chamado Dossiê Formal de Liberação (o "Dossiê"), devidamente acompanhado de amostras do Produto à fábrica de NESTLÉ indicada no Projeto ("Fábrica Controladora") ;

(ii) No mesmo momento, serão enviadas outras amostras do Produto ao Laboratório Regional de NESTLÉ, localizado na cidade de São Paulo, a Avenida Guido Caloi, n 1935 , Jd. São Luis.;

(iii) Sobre as amostras enviadas à Fábrica Controladora jūntamente com o Dossiê, será realizada por NESTLÉ uma análise sensorial organoléptica, enquanto que sobre as amostras enviadas ao Laboratório Regianal de NESTLÉ, será realizada por esta uma análise microbiológica ;

(iv) Para os casos em que houver necessidade de repetição da análise microbiológica, a Fábrica Controladora deverá informar a "OFICINA DO CACAU" logo após recebimento do primeiro resultado emitido pelo Laboratória Regional, ficando a "OFICINA DO CACAU" responsável por enviar novas amostras ao Laboratório Regional, conforme previsto no Plano de Monitoramento Microbiológico que constará do Projeto.

(v) A responsabilidade pelo transporte, inclusive no que se refere aos seus respectivos custos, do Dossiê e das amostras de cada lote de Produto, tanto para a Fábrica Controladora quanto para o Laboratório Regional previsto no item (ii) acima, será total e exclusiva de "OFICINA DO CACAU" ;

(vi) Por outro lado, a responsabilidade pelas Análises das amostras e os respectivos custos inerentes às suas realizaçōes será total e exclusiva de NESTLÉ, salvo nos casos onde houver resultado fora de norma na primeira análise microbiológica e conseqüente necessidade de repetição, conforme previsto no item (iv) acima, nos quais os custos inerente a essas repetições serão re responsabilidade da "OFICINA DO CACAU".

6

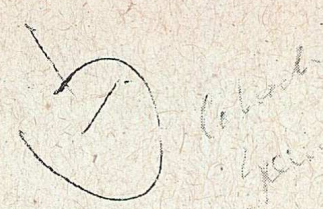


(vii) Do momento em que NESTLÉ receba de "OFICINA DO CACAU" o Dossiê e as amostras nos locais indicados acima, o que não poderá ocorrer com mais de 02 (dois) dias da entrega dos Produtos, NESTLÉ terá 30 (trinta) dias para manifestar qualquer discordância quanto à qualidade e/ou características do lote de Produtos referente às amostras que estão sendo objeto das Análises, ocorrendo a formal liberação e aceite de todo o respectivo lote de Produtos por parte de NESTLE se dentro de tal prazo esta não efetue qualquer manifestação contrária ;

(viii) Tendo em vista o previsto na Cláusula Quinta, no periodo em que as Análises estiverem sendo realizadas, os Produtos deverão permanecer armazenados sob responsabilidade de NESTLÉ, sendo considerados aceitos ou não somente no momento em que ocorrer uma das hipóteses previstas no item anterior.

6.3 O lote ou lotes dos Produtos recusados pela NESTLÉ serão devolvidos à "OFICINA DO CACAU" e esta poderá, por sua própria conta, reutilizá- los segundo seja legalmente permitido ou destruí-los, assumindo o custo respectivo em ambos casos. Fica expressamente estabelecido que a "OFICINA DO CACAU" não poderá utilizar os Produtos recusados pela NESTLÉ para fins de revenda como produtos alimentícios industrializados, já que os Produtos serão industrializados e fornecidos sob encomenda e com exclusividade pela "OFICINA DO CACAU" à NESTLÉ.

6.4 A NESTLÉ não terá a obrigação de pagar pelo lote ou lotes dos Produtos que sejam por ela recusados conforme o previsto nos parágrafos 6.1 e 6.2 anteriores.

No caso de a NESTLÉ já haver pago à "OFICINA DO CACAU" pelos serviços de industrialização e fornecimento do lote ou lotes dos Produtos que posteriormente sejam recusados de acordo com o previsto nesta cláusula, a "OFICINA DO CACAU" deverá reembolsar à NESTLÉ, na forma a ser acordada entre as partes, o custo de tais serviços que estiverem relacionados com o lote ou lotes de industrialização correspondentes, bem como qualquer outro custo ou gasto que a NESTLÉ tenha arcado em relação com a não aceitação dos Produtos.

6.5. O custo das referidas açōes e de industrialização do lote ou lotes de Produtos recusados serão imputados à "OFICINA DO CACAU", conforme procedimento previsto nesta cláusula, a menos que a situação gerada não tenha relação com qualquer ação ou omissão da "OFICINA DO CACAU".

\section{CLÁUSULA SÉTIMA - CUMPRIMENTO DAS NORMAS APLICÁVEIS}

7.1 A "OFICINA DO CACAU" se compromete a manter todas as instalações da Fábrica em condições ótimas de funcionamento, segurança e higiene, bem como a cumprir todas as normas legais aplicáveis, ademais de manter em plena vigência todas as autorizações, licenças e registros oficiais necessários, especialmente aqueles relacionados com o funcionamento e segurança da Fábrica, segurança do trabalho e licenças das autoridades sanitárias.

7.2 Além do previsto no parágrafo anterior, "OFICINA DO CACAU" se compromete a, além de seguir os Conhecimentos de cada um dos Produtos que the sejam encomendados e observar todos os requisitos do Nivel 1 de prioridade do NQS 
(Nestlé Quality System) de NESTLÉ do Anexo B, a aplicar e respeitar o NESTLÉ Corporate Business Principles, cujo conteúdo se anexa ao presente Contrato por meio de seu Anexo $C$.

7.3 A "OFICINA DO CACAU" industrializará e armazenará os Produtos de conformidade com as leis c normas aplicáveis.

7.4 A "OFICINA DO CACAU" deverá informar à NESTLÉ toda e qualquer anomalia detectada na Fábrica por inspeções das autoridades competentes que detectem. qualquer situação que possa por em risco o cumprimenta dos Conhecimentos e demais especificaçōes na industrialização e armazenagem dos Produtos previstas e exigidas por este Contrato.

7.5 A "OFICINA DO CACAU" deverá manter adequadamente a documentação referente ao recebimento e utilização dos Insumos, industrialização (fabricação e/ou acondicionamento), armazenagem e controle da qualidade dos Produtos, a fím de ser examinada pela NESTLÉ, quando assim esta o desejar, ou pelas autoridades competentes. CLÁUSULA OITAVA - PRECO, FATURAMENTO, FORMA DE PAGAMENTO E
PROCEDIMENTOS FISCAIS

\subsection{Preço}

O custo total dos serviços de industrialização (fabricação elou acondicionamento), fornecimento e entrega dos Produtos pela "OFICINA DO CACAU" à NESTLÉ serão determinados nos respectivas Projetos, conforme previsto na Cláusula Segunda - 2.2 (e), que estabelece que todas as condições comerciais, tais como preços e respectivos critérios e formas de revisáo e os procedimentos fiscais a serem aplicados, para cada Produto encomendado por NESTLÉ à "OFICINA DO CACAU", deverāo constar do Projeto correspondente.

O reajuste do preço de um Projeto será feito sempre a cada período de 12 (doze) meses, contados a partir do ínício de sua vigência, sendo certo que o índice a ser aplicado estará definido no anexo do Projeto que trata das condições comerciais e fiscais correspondentes (Cláusula Segunda - 2.2 (e)).

Sem prejuízo do reajuste previsto no parágrafo acima, as partes concordam em revisar o preço de um Projeto, em período inferior a um ano, na ocorrência de fatos imprevistos que afetem o equilíbrio econômico de mencionado Projeto, mediante a apresentação de planilha de estrutura de custos que demonstre, de forma incontestável, o desequilibrio incorrido.

\subsection{Faturamento e Forma de Pagamento}

A NESTLÉ pagará à "OFICINA DO CACAU" o custo total dos serviços contemplados neste Contrato e nos Projetos correspondentes, no prazo estipulado no respectivo Projeto, sempre contados a partir da data de emissão da respectiva nota fiscal/fatura, a qual deverá ser entregue por "OFICINA DO CACAU", à NESTLÉ com antecedência mínima de 15 (quinze) dias úteis da data do vencimento.

8

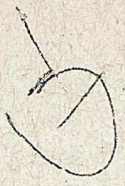


Não obstante o estipulado no parágrafo anterior, a NESTLÉ não poderá ser responsabilizada por atrasos no pagamento de lotes de industrialização dos Produtos se a respectiva nota fiscal/ fatura tiver sido enviada tardiamente pela "OFICINA DO CACAU", OU tiver sido emitida sem preencher os requisitos fiscais previstos na legislação $e$ regulamentação em vigor, em cujo caso a NESTLÉ efetuará tal pagamento somente após 15 (quinze) dias úteis após o recebimento efetivo da nota fiscal/fatura correta.

Na hipótese de que um determinado lote de industrialização dos Produtos não seja aprovado e liberado pela NESTLÉ, por năo cumprir com os termos e condições deste Contrato ou dos respectivas Conhecimentos, esta estará facultada a não realizar o pagamento correspondente, conforme parágrafos 6.4 e 6.5 da Cláusula Sexta.

A "OFICINA DO CACAU" deverá emitir as notas fiscais/faturas pela industrialização e entrega dos Produtos à NESTLE em nome desta última, de acordo com as normas fiscais vigentes

\section{CLÁUSULA NONA - VIGÊNCIA E DURACCÃO}

9.1 Este Contrato entra em vigor a partir da data de sua assinatura por ambas as partes e vigerá por prazo indeterminado.

9.2 Qualquer uma das Partes poderá dar por terminado este Contrato, ou qualquer um dos Projetos específicos, a qualquer momento durante a sua vigência, sendo suficiente para tanto o envio de uma comunicação por escrito a outra Parte com 180 (cento e oitenta) dias de antecipação à data na qual a parte interessada pretende que sejam produzidos os efeitos da terminaçăo.

9.3 No que diz respeito aos Projetos, conforme previsto no Anexo A, em cada um deles estará previsto o prazo de vigência específico para a industrialização e fornecimentos do Produto nele envolvido.

9.3.1 Caso as partes tenham interesse em prorrogar o prazo de vigência do Projeto por igual periodo, deverão manifestar sua intenção através do envio de comunicação formal à outra parte, com 60 (sessenta) dias de antecedência ao término do prazo de vigência do Projeto.

\section{CLÁUSULA DÉCIMA - EXCLUSIVIDADE}

10.1 Tendo em vista o detalhado na cláusula 15.3, a "OFICINA DO CACAU" nào poderá, de nenhuma forma, seja diretamente ou por intermédio de sociedades afiliadas, ou por qualquer relação de fato, contratual, combinação ou associação empresarial, desenvolver, elaborar, fabricar, fornecer e vender os Produtos a terceiros. Esta obrigação da "OFICINA DO CACAU" perdurará enquanto esteja vigente este Contrato e após a sua terminação.

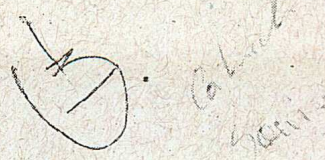




\section{CLÁUSULA DÉCIMA PRIMEIRA - CONFIDENCIALIDADE}

11.1 As Partes aceitam e reconhecem que a totalidade da informação técnica e comercial que se refira ao desenvolvimento e execução das atividades previstas neste Contrato deverão ser consideradas como confidencial e segredo de negócio.

11.2 Tendo em vista o disposto no parágrafo precedente, a totalidade da informação técnica e comercial relacionada com a industrialização, armazenagem e entrega dos Produtos que a "OFICINA DO CACAU" venha a ter acesso, por meio dos seus diretores, empregados e representantes, deverá sempre ser recebida e conservada sob estrito sigilo e confidencialidade, com o caráter de segredo de negócio, pelo que a "OFICINA DO CACAU" se obriga perante a NESTLÉ em seu próprio nome e em nome dos seus diretores, empregados e representantes a näo revelá-la a terceiros em geral, exceto se expressamente permitido pela NESTLÉ neste Contrato ou mediante comunicação por escrito dirigida à "OFICINA DO CACAU" em tal sentido. Assim, a "OFICINA DO CACAU" se obriga a utilizar tal informação exclusivamente para os fins contemplados neste Contrato.

\section{CLÁUSULA DÉCIMA SEGUNDA - DESCUMPRIMENTO}

12.1 O descumprimento parcial ou total das obrigações atribuidas a cada uma das Partes estipuladas neste Contrato e seus Anexos presentes ou futuros, outorga o direito a outra Parte de rescindir o presente, sem necessidade de notificação judicial ou extra-judicial, sempre e quando a Parte que tiver deixado de cumprir com qualquer das suas obrigaçōes contratuais não tome as providencias necessárias para corrigir tal descumprimento dentro de 30 (trinta) dias após ter recebido a comunicação por escrito que the tenha sido enviada pela outra Parte para que sane o descumprimento cometido.

12.2 Ademais, o direito de rescindir este Contrato nos termos do parágrafo anterior será cumulativo com o direito da Parte afetada de exigir da Parte infratora o pagamento de uma multa pecuniária no valor máximo de $\mathrm{R} \$ 50,000,00$ (cinqüenta mil reais), além dos danos e prejuízos eventualmente apurados.

\section{CLÁUSULA DÉCIMA TERCEIRA - EXTINCÃO DA RELACÃO CONTRATUAL}

13.1 Com relação à rescisão unilateral deste Contrato com expressão de causa, cujo conceito geral se encontra definido e previsto na cláusula anterior, fica estabelecido que tal iniciativa poderá ser tomada nas situações descritas a seguir, em forma enunciativa mas nào limitativa: .

a) Por qualquer uma das Partes, a qualquer momento, ante qualquer descumprimento da outra Parte das obrigações sob sua responsabilidade de acordo com o previsto neste Contrato, especialmente nos casos de falta de industrialização e fornecimento dos Produtos e de não aplicação ou aplicaçãa incompleta dos Conhecimentos e dos conceitos trazidos pelos Anexos B e C

10

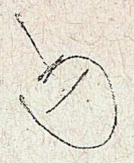


do presente.

b) Pela NESTLÉ, no caso de venda da Fábrica pela "OFICINA do CACAU" a terceiros.

c) Por qualquer uma das Partes, se a outra Parte tiver decretada a sua concordata ou falência, for objeto de uma dissolução societária ou encontrarse na impossibilidade de fato de cumprir com os seus compromissos financeiros com seus credores ou qualquer outro fato indicativo de estado de cessação de pagamentos.

d) Por qualquer uma das Partes, se a outra Parte ficar impossibilitada de cumprir com as suas obrigações contratuais, sem prejuizo da respectiva indenização por perdas e danos que possa corresponder.

\section{CLÁUSULA DÉCIMA QUARTA - RESPONSABILIDADES}

14.1 A "OFICINA DO CACAU" se compromete a cumprir cabalmente com as suas obrigações estipuladas neste Contrato, especialmente aquelas relacionadas com o cumprimento e aplicação dos Conhecimentos, bem como o cumprimento e aplicação das normas legais aplicáveis às suas atividades decorrentes da execução do objeto do presente e dos conceitos trazidos pelos Anexos B e C.

14.2 No caso de ocorrer qualquer problema referente à qualidade dos Produtos, seja de natureza sanitária, microbiológica ou organoléptica, a Parte que tomar conhecimento em primeiro lugar de tal fato, deverá notificar imediatamente a outra Parte, a fim de que, conjuntamente, possam tomar as medidas necessárias no menor tempo possível com o objetivo de assegurar o bem estar dos consumidores, bem como corrigir o problema ocorrido.

14.3 No caso de que ocorra um problema de qualidade e/ou segurança dos Produtos por irregularidades na recepção ou utilização dos Insumos ou na industrialização ou manipulação dos Produtos na Fábrica, fica estipulado que, ademais do procedimento de aceitação dos Produtos previsto na Cláusula Sexta, a "OFICINA DO CACAU" será responsável ante terceiros em geral, sobretudo perante os consumidores, por todo e qualquer gasto, perda ou dano. Neste sentido, a "OFICINA DO CACAU" deverá manter a NESTLÉ isenta de qualquer reclamação, queixa, denúncia e/ou ação iniciada por terceiros ou autoridades federais, estaduais e municipais, pelo que deverá assumir responsabilidade integral e responder isoladamente a tal reclamação, queixa, denúncia e/ou ação, requerendo a exclusão da NESTLÉ do pólo passivo da lide, caso esta figure na demanda, e assumindo, conseqüentemente, os gastos gerados e indenizações que sejam determinadas.

14.3.1 Para efeito do previsto no parágrafo 14.3 acima, qualquer autuação, notificação ou intimação recebida pela NESTLÉ, relativa a qualquer dos Produtos, será repassada imediatamente para a "OFICINA DO

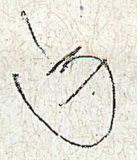


CACAU" para que tome as providências cabiveis. Sendo a NESTLÉ obrigada a efetuar qualquer pagamento em virtude do que prevê o parágrafo acima, em decorrência de decisão irrecorrivel de órgão público elou de processo judicial, a "OFICINA DO CACAU" compromete-se a reembolsá-la em até 30 (trinta) dias após a comunicação do efetivo desembolso.

14.4 A "OFICINA DO CACAU" manterá em correto funcionamento os seus sistemas de proteção contra roubo, furto e incêndio e, quando aplicável, deverá possuir uma brigada de incêndio devidamente treinada.

14.5 A "OFICINA DO CACAU" se compromete a estabelecer um plano de crise no caso de acidentes que afetem os insumos e/ou produtos da NESTLÉ, comunicando e acionando o setor Administrativo e a Gerencia da "Fabrica controladora" e ao mesmo tempo evitando descaracterizar o local do acidente até que' a NESTLÉ, através da "Fabrica controladora", inicie as medidas necessárias, juntamente com a respectiva empresa Seguradora.

14.6 A "OFICINA DO CACAU" deve por outro lado manter um seguro de responsabilidade civil geral ante terceiros que abranja as atividades que levará a cabo para o cumprimento do objeto deste Contrato

14.7 No caso de que alguma possivel irregularidade relacionada com os Produtos ocorra em decorrência de uma manipulação inadequada por parte da NESTLÉ, situação esta que deverá ser devidamente comprovada, esta última será responsável por toda e qualquer reclamação, queixa, denúncia elou ação iniciada por terceiros ou autoridades federais, estaduais e municipais.

\section{CLÁUSULA DÉCIMA QUINTA - DISPOSICÕES GERAIS}

\subsection{Instalações}

A "OFICINA DO CACAU" assegura que a Fábrica possui as instalações e condições necessárias para a industrialização e fornecimento dos Produtos.

\subsection{Independência e Autonomia}

a) A presente relação contratual entre a NESTLÉ e a "OFICINA DO CACAU" se caracteriza como sendo uma relação entre contratantes independentes, razão pela qual este Contrato não cria entre as Partes qualquer relação de representante e representado, em forma única ou reciproca, nem constitui qualquer tipo de associaçāo solidária, respondendo cada uma das Partes perante a outra e terceiros em forma individual e isolada pelos seus atos e/ou omissōes.

b) Nenhuma das Partes estará facultada para constituir ou assumir em nome da outra Parte qualquer obrigação, expressa ou tácita, agir ou dar a entender que age como sua procuradora ou representante legal, para qualquer fim que seja.

c) A "OFICINA DO CACAU" levará a cabo as suas atividades previstas nesté Contrato

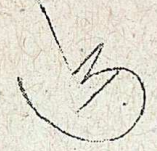




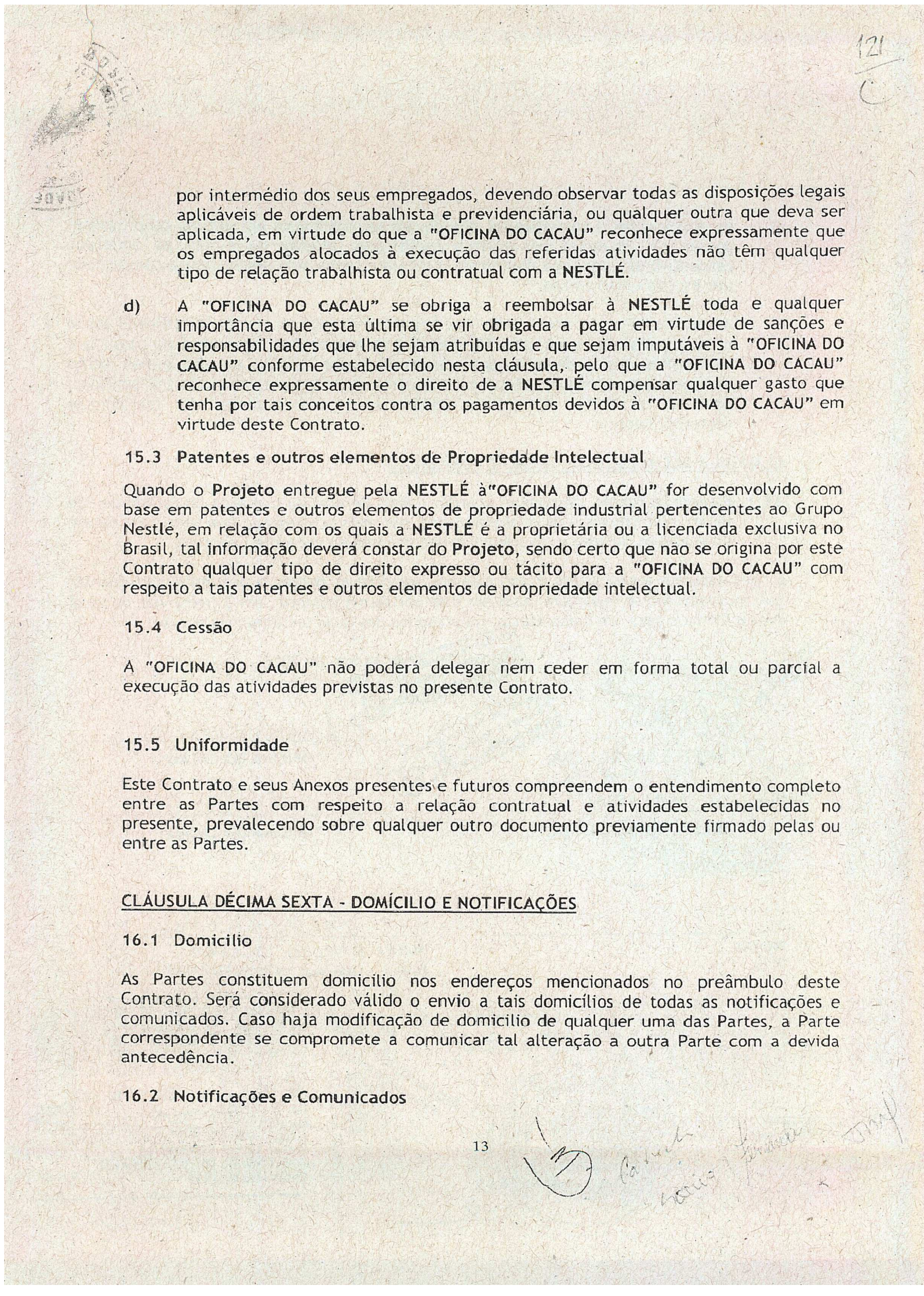




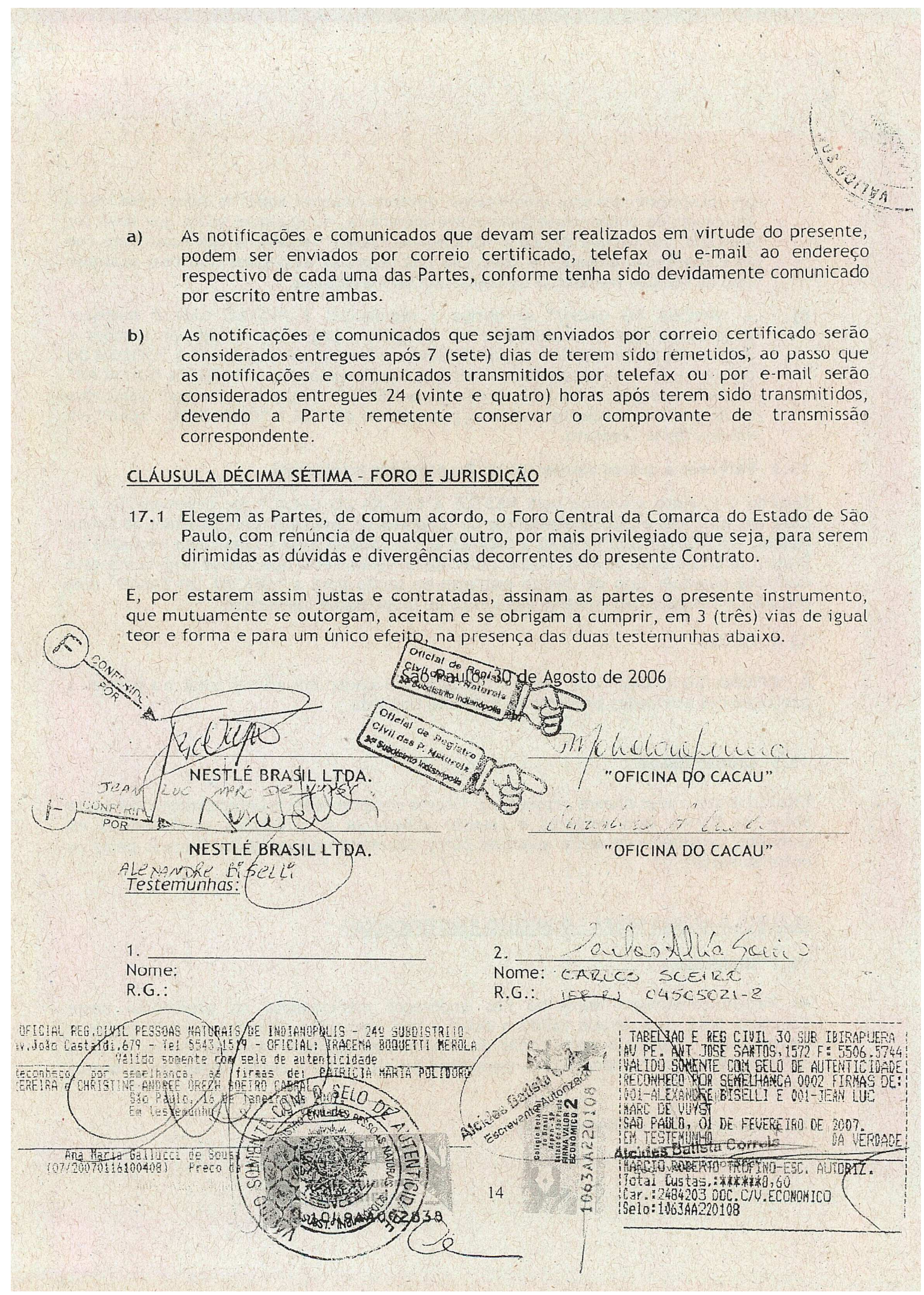


ANEXO 2 - Sentença autos no 0000889-03.2011.5.15.0138 


\section{VARA DO TRABALHO DE JACAREÍ \\ PROCESSO № 0000889-03.2011.5.15.0138 \\ Reclamante: CLAUDILENE RODRIGUES DA SILVA \\ 1aㅡㄹ Reclamada: OFICINA DE CACAU INDÚSTRIA E COMÉRCIO DE GÊNEROS ALIMENTÍCIOS LTDA \\ 2a Reclamada: NESTLÉ BRASIL LTDA}

A reclamante, qualificada às fls. 02 , apresenta reclamação trabalhista em face das reclamadas, também qualificadas. Afirma ter trabalhado de06.11.07 a 08.08.11, tendo percebido $\mathrm{R} \$ 746.50$ como última remuneração. Foi dispensada sem justa causa e sem pagamento das verbas rescisórias. Trabalhava na atividade-fim da segunda reclamada. Postula o pagamento de penalidade do artigo 467da CLT, saldo salarial, aviso prévio, décimo terceiro salário proporcional, férias integrais e proporcionais, ambas acrescidas de um terço, FGTS mais multa, multa convencional pelo atraso no pagamento das verbas rescisórias, cesta básica, indenização do seguro desemprego, honorários advocatícios, além da expedição de ofícios. Juntou procuração e documentos. Valorou a causa em $\mathrm{R} \$ 27.275,35$.

As reclamadas foram citadas, compareceram à audiência e apresentaram defesa escrita acompanhada de documentos.

A primeira reclamada apresentou preliminar de carência de ação por falta de submissão à Comissão de Conciliação Prévia. Afirma que aviso prévio, décimo terceiro salário proporcional, férias proporcionais mais um terço, saldo de salário, FGTS e seguro desemprego foram quitados no momento da dispensa. Não foram realizados os depósitos de FGTS e multa em razão do pedido de recuperação judicial. Contestou o pedido. Requereu a compensação.

A segunda reclamada impugnou o valor dado à causa e apresentou preliminar de ilegitimidade de parte. Alega não ser a empregadora da reclamante. Firmou contrato de industrialização e fornecimento sob encomenda de produtos e outras avenças com a primeira reclamada, sendo que sua posição se assemelha á figura do dono da obra, não se tratando de terceirização. A primeira reclamada não trabalhava exclusivamente para a Nestlé. Contesta o pedido.

Determinada a expedição de alvará para levantamento do FGTS depositado na conta vinculada da autora e habilitação aos benefícios do seguro desemprego.

A reclamante comprova os valores sacados às fls. 148/149.

Foi colhido o depoimento pessoal do primeiro reclamado e sem

outras provas, foi encerrada a instrução processual.

Razões finais remissivas.

Conciliação final rejeitada.

É o relatório.

\section{DECIDO}




\section{Da impugnação ao valor dado à causa}

A impugnação ofertada pela reclamada é rejeitada, posto que o valor atribuído à causa é compatível com o valor do pedido inicial.

Demais disto, simples impugnação sem que haja fundamento da incorreção do valor atribuído à causa e fixação do quantum não é suficiente para comprovar a violação aos dispositivos legais aplicáveis ao caso.

\section{Da Comissão de Conciliação Prévia}

Rejeito a preliminar, porquanto a ausência de submissão prévia da demanda em comissão de conciliação prévia não pode impedir o Poder Judiciário de apreciar alegação de lesão ou ameaça a direitos, nos exatos termos do art. $5^{\circ}, \mathrm{XXXV}$, da CF/88. 2160.

Nesse sentido, aliás, já se pronunciou o Excelso STF nas ADls 2139 e

Outrossim, a primeira reclamada sequer comprovou a existência de CCP instituída no local da prestação de serviços do reclamante.

\section{Da carência de ação}

A legitimidade para agir, chamada por Liebman de pertinência subjetiva da ação, significa que parte legítima é aquela que afirma ser titular de uma pretensão jurídica bem como aquela em face de quem se pretende a prestação.

A legitimidade de parte deve ser verificada pelo juiz de forma abstrata, a partir das alegações constantes na petição inicial, precariamente admitidas como verdadeiras ( in status assertionis), deixando o juízo axiológico sobre sua certeza para o momento processual oportuno, através da apuração da matéria fática colhida na instrução processual.

\section{Da ilegitimidade de parte - segunda reclamada}

Tendo a reclamante sido contratado pela primeira reclamada para prestar serviços para a segunda demandada, requerendo a responsabilização subsidiária desta, conforme entendimento jurisprudencial expresso na Súmula 331 do TST, é evidente a pertinência subjetiva da ação.

Preliminar rejeitada.

\section{Das contribuições previdenciárias - ofício ao INSS}

A reclamante pretende a expedição de ofício ao INSS porque existiriam fortes indícios de que a reclamada descontou a parcela de contribuição dos empregados, mas não efetuou o recolhimento ao órgão previdenciário.

Indefiro.

Cabia à reclamante juntar Extrato de Informações Previdenciárias, o qual pode ser obtido através da internet, no Portal da Previdência Social e 
dessa forma saberia se o empregador estava ou não recolhendo suas contribuições, não cabendo ao Juízo fazer prova para a parte.

\section{Da motivação rescisória - verbas rescisórias}

A primeira reclamada afirma que aviso prévio, férias mais um terço e décimo terceiro salário proporcionais, saldo de salário, FGTS e seguro desemprego foram quitados no momento da dispensa.

Demais disto, não foram realizados os depósitos de FGTS acrescidos da multa de $40 \%$ em virtude de pedido de recuperação judicial.

Inexistem recibos de pagamento e tampouco há qualquer indício da existência de recuperação judicial.

Incontroversa a dispensa sem justa causa, faz jus a reclamante ao pagamento de: saldo salarial de oito dias de agosto de 2011 - $R \$ 199,06$, aviso prévio indenizado - $\mathrm{R} \$ 746,50,8 / 12$ de décimo terceiro salário proporcional $R \$ 497,66$, um período integral de férias mais um terço - $R \$ 995,33,10 / 12$ de férias mais um terço - $R \$ 829,44$, diferenças de FGTS - R $\$ 1.358,29$, FGTS sobre verbas rescisórias ( saldo de salário, aviso prévio indenizado e décimo terceiro salário)- $R \$ 115,45$, multa de $40 \%$ do FGTS - R $\$ 1.192,80$, multa convencional pelo atraso no pagamento das verbas rescisórias ( $8^{\text {a }}$ cláusula do Acordo Coletivo de Trabalho) - $R \$ 1.493,00$, penalidade do artigo 467 da CLT ante a ausência de controvérsia acerca das verbas rescisórias $\mathrm{R} \$ 2.230,39$.

Ante os termos da presente, ratifico a antecipação de tutela consistente na expedição de alvará para levantamento do FGTS depositado em conta vinculada e habilitação aos benefícios do seguro desemprego.

\section{Da cesta básica}

Ausentes recibos de pagamento, faz jus a reclamante ao pagamento de cinco cestas básicas, conforme previsão da cláusula $24^{a}$ do ACT, no valor de $R \$ 70,00$ mensais $-R \$ 350,00$.

\section{Da responsabilidade da segunda reclamada}

Afirma a segunda reclamada que não se trata de terceirização, mas sim de contrato de industrialização e fornecimento sob encomenda de produtos e outras avenças, assemelhando-se à condição do dono da obra.

A cláusula terceira do contrato social aponta que o objetivo social da segunda reclamada, entre outros é a fabricação, transformação, beneficiamento, conservação, estocagem, distribuição, importação, exportação, comércio de produtos alimentícios e bebidas em geral.

O contrato celebrado entre as reclamadas estabelece que a primeira reclamada é contratada para a industrialização e fornecimento sob encomenda de algumas variedades de produtos alimentícios, com base nas receitas, fórmulas e especificações de propriedade ou desenvolvidas para a primeira reclamada, Nestlé. 
Muito embora a produção fosse realizada nas dependências da primeira reclamada, a prova documental e oral demonstram que o que ocorria, efetivamente, era a prestação de serviços pela primeira reclamada em favor da segunda e isso na atividade-fim desta.

A hipótese amolda-se ao entendimento consagrado na Súmula 331, 1 do E.TST, mas dada a ausência de pedido de vínculo direto com a segunda reclamada e, pois, nos limites do pedido, aplico o disposto no inciso IV da mesma Súmula e condeno a segunda reclamada a arcar de forma subsidiárias com os créditos ora deferidos à reclamante.

Não há se falar em exclusão de verbas de natureza punitiva e personalíssima da primeira reclamada, eis que a Súmula 331 do C. TST não faz qualquer exclusão.

Tampouco há se falar em desconsideração da pessoa jurídica quanto à primeira reclamada, eis que não foi sequer iniciada a execução, valendo a pena ressaltar já neste momento processual, que a posição do tomador dos serviços é equiparável à do fiador, invocando-se em face da inexistência de norma expressa na CLT, o contido nos arts. 827 e seguintes do CC, pelos quais 0 benefício de ordem decorre da natureza normalmente subsidiária ou complementar da responsabilidade do fiador, desaparecendo este benefício se o fiador renunciou expressamente ao benefício, se o mesmo se obrigou como principal pagador ou devedor solidário, ou ainda e principalmente, sendo 0 afiançado pessoa insolvente ou falida (art. 828, CC).

Ora, se o benefício de ordem não subsiste diante da falência da pessoa jurídica, com muito maior razão, não se justifica a desconsideração da pessoa jurídica da prestadora dos serviços como requisito ao cumprimento do comando jurisdicional que reconhece a responsabilidade subsidiária da tomadora dos serviços e principal beneficiária destes.

Ao tomador dos serviços resta buscar a satisfação do seu crédito regressivo em face da devedora principal, seus sócios ou mesmo a massa falida, se o caso, pois o simples pagamento da dívida já o sub-roga nos direitos do credor. O que não se admite é a transferência deste ônus ao trabalhador.

\section{Da compensação/dedução}

Não há comprovação nos autos de pagamento de qualquer valor pelos títulos que foram objeto de condenação, não havendo dedução/compensação a ser autorizada.

\section{Da assistência judiciária}

Defere-se a gratuidade processual, com a isenção das custas e emolumentos, ante a demonstrada insuficiência de recursos e o dever do Estado de prestar a assistência judiciária integral e gratuita, nos termos da Lei 1060/50 e o art. 5으,

LXXIV da CRFB/88.

\section{Dos honorários advocatícios sucumbenciais}

Quanto aos honorários advocatícios, acompanhávamos a Jurisprudência predominante consubstanciada nas Súmulas 219 e 329 do C. 
TST, considerando ser imprescindível a assistência jurídica prestada por sindicato à da parte sucumbente para a condenação do ex adverso nos honorários advocatícios, nos termos da Lei 5.584/70, no entanto, os dispositivos que tratavam desta matéria foram revogados pela Lei 10.288/01 que modificou a redação do art. 789 da CLT, acrescentando-lhe o parágrafo $10^{\circ}$, por ser mais recente e tratar da matéria específica e idêntica àquela (art. 2ํ, § 1ํ da Lei de Introdução ao Código Civil).

Posteriormente, esta norma celetista foi novamente modificada, Lei $10.537 / 2002$, suprimindo o parágrafo $10^{\circ}$, com o que, deixou de existir na norma consolidada e legislação específica, qualquer regramento à condenação em honorários advocatícios nesta Justiça Especializada, pois a revogação da norma recente não confere vigência tácita aos dispositivos por esta revogados, eis que é inadmissível em nosso ordenamento jurídico efeito repristinatório.

Com isso, deve o intérprete socorrer-se do direito comum ao tratar da assistência jurídica ao hipossuficiente nesta Justiça Especializada, observando a Lei 1060/50 que trata da matéria de forma pormenorizada e não faz qualquer exigência à assistência sindical para a condenação à verba honorária.

Não se pretende aqui negar vigência ao artigo 791 da CLT, mas há que ser considerado que a sua aplicabilidade nas Varas do Trabalho demonstra-se excepcional, não justificando a negativa de condenação ao pagamento de honorários advocatícios no processo do trabalho, notadamente quando as questões em discussão, cada vez mais, tornam a figura do advogado imprescindível à prestação jurisdicional.

Por fim, é oportuno considerar que o novo Código é bem mais severo com o devedor inadimplente, enfraquecendo ainda mais os argumentos que não consideravam devidos os honorários advocatícios na Justiça do Trabalho, pois, nos termos do artigo 389 do Novo Código Civil, o devedor que não cumpre a obrigação de pagar, no prazo devido, responde por perdas e danos, mais juros, atualização monetária e honorários advocatícios.

Portanto, sempre que as partes estiverem assistidas por advogado, mesmo quando este estiver atuando em causa própria, serão devidos os honorários advocatícios, nos termos do art. 20 e seguintes do CPC, de aplicação subsidiária ao processo do trabalho, salvo quanto à sucumbência recíproca e proporcional, eis que esta é inaplicável ao processo do trabalho, adotando-se o mesmo princípio que rege o pagamento das custas, ou seja, o obreiro somente será condenado em custas e honorários advocatícios quando o pedido for totalmente improcedente.

Assim sendo, defiro os honorários advocatícios arbitrados em 15\% sobre o valor da condenação, considerando para fins de arbitramento os termos do art. $20^{\circ}$, $\S 3^{\circ}$ do CPC.

Pelo exposto, o Juízo da $2^{\text {a }}$ Vara do Trabalho de Jacareí decide, com base nos elementos constantes dos autos e nos termos da fundamentação, julgar PROCEDENTE EM PARTE o pedido proposto por CLAUDILENE 
RODRIGUES DA SILVA em face de OFICINA DO CACAU INDÚSTRIA E COMÉRCIO DE GÊNEROS ALIMENTíCIOS LTDA e NESTLÉ BRASIL LTDA para condenar as reclamadas, a segunda demandada de forma subsidiária, ao pagamento de saldo salarial de oito dias de agosto de $2011-R \$ 199,06$, aviso prévio indenizado - $R \$ 746,50,8 / 12$ de décimo terceiro salário proporcional $R \$ 497,66$, um período integral de férias mais um terço - $R \$ 995,33,10 / 12$ de férias mais um terço - $R \$ 829,44$, diferenças de FGTS - $R \$ 1.358,29$, FGTS sobre verbas rescisórias ( saldo de salário, aviso prévio indenizado e décimo terceiro salário)- $\mathrm{R} \$ 115,45$, multa de $40 \%$ do FGTS - R\$1.192,80, multa convencional pelo atraso no pagamento das verbas rescisórias ( $8^{\text {a }}$ cláusula do Acordo Coletivo de Trabalho) - $\mathrm{R} \$ 1.493,00$, penalidade do artigo 467 da CLT - R\$2.230,39 e cestas básicas - R\$ 350,00.

As reclamadas são também condenadas ao pagamento de honorários advocatícios.

Tendo em vista a ampliação de competência desta Justiça Obreira para executar as contribuições sociais decorrentes de suas sentenças, conforme o art. 114, VIII da Constituição Federal e artigo 876 da CLT, com a nova redação dada pela lei 11.457/07, consoante disposto no art. 832, § $3^{\circ}$ da CLT, esclareço que não compõem o salário-de-contribuição, as seguintes parcelas: aviso prévio indenizado, férias indenizadas mais um terço, FGTS mais multa, multa convencional e cesta básica.

Contribuições sociais e fiscais, juros e correção monetária, nos termos das Súmulas 200 e 381 do C. TST, ficando autorizadas as retenções legais (Súmula368/TST), conforme assim calculado:

Atualização:14.02.2012

Juros: 19.09 .2011

INSS (incidência sobre R $\$ 696,72$ )

INSS Recte. (8\%) :..............R $\$ 55,73$ - atualizado: $\mathrm{R} \$ 56,01$

INSS Recda.(28,8\%):...........R \$ 200,65 - atualizado: $\mathrm{R} \$ 201,64$

Principal .............................R $\$ 10.057,29$

Juros ...............................R $\$ \quad 492,81$

Hon. Advocatícios ..............R $\$ \quad 1.582,51$

INSS recda. ........................R $\$ 201,64$

Total Bruto ..........................R\$ 12.334,25

- INSS recte. ......................R $\$ \quad 56,01$

- IRRF .......................................... Isento

Total Líquido ......................... $\$ 12.076,60$

Custas pelas reclamadas, no importe de $R \$ 248,00$, calculadas sobre $o$ valor atribuído à condenação de $\mathrm{R} \$ 12.400,00$, que deverão ser recolhidas em Guia de Recolhimento da União -GRU Judicial, sob o código de recolhimento 8.740-4 - STN - Custas (CAIXA/BB), conforme Anexo I do Ato Conjunto no 21/2010 TST.CSJT.GP.SG (DEJT de 09/12/2010), sendo que o campo obrigatório designado para "número de processo/referência" deverá ser 
preenchido também com o código numérico 080011, atribuído a esta Unidade Gestora, nos termos do Anexo II daquele mesmo Ato Conjunto.

Atendendo aos princípios da celeridade e eficácia, que regem o processo do trabalho, reforçados pela Emenda Constitucional 45 que erigiu à condição de direito constitucional o tempo razoável de duração do processo (art. 5o, XXVIII, CF), e ainda levando em consideração a interpretação teleológica do art. 769 da CLT, cuja finalidade precípua é evitar a sua contaminação pelo modelo civilista em prejuízo à eficácia e informalidade das regras consolidadas, bem como, diante da criação no paradigma processual comum de regra que melhor atende às necessidades do processo do trabalho, determino o cumprimento da sentença, ficando INTIMADA a PRIMEIRA reclamada(o), através de seu(sua) i. patrono(a), para quitar o valor devido, inclusive as contribuições sociais, no prazo de 15 dias a contar do trânsito em julgado, sob pena do montante da condenação ser acrescido de multa no percentual de $10 \%$, nos termos do caput do art. 475-J do CPC, competindo a(o) mesma(o) comparecer em secretaria do Juízo para a atualização dos valores devidos no momento do pagamento.

O VALOR DAS CONTRIBUIÇÕES SOCIAIS DEVERÁ SER ATUALIZADO PELA TAXA SELIC NA DATA DO PAGAMENTO, observando-se os critérios adotados pelo INSS e recolhidos através da guias guias GFIP e GPS, comprovado nos autos em 03 ( três) vias, 1 original e demais em cópias AUTENTICADAS.

A emissão da GPS com os acréscimos legais poderá ser efetuada junto ao site www.previdenciasocial.gov.br, opção CONTRIBUIÇÕES, sub-opção CONSULTAS-CALCULE SUA CONTRIBUIÇÃO.

Considerando a Portaria oㅜ 435 do Ministério da Fazenda, de 08.09.11 e a Recomendação GP-CR oㅜ 03/2011 do E.TRT, desnecessária a intimação da União.

Intimem-se as partes.

Jacareí, 14 de fevereiro de 2012.

ROSANA FANTINI NICOLINI

Juíza do Trabalho 
ANEXO 3 - Acórdão autos no 0000889-03.2011.5.15.0138 
6" CÂMARA (TERCEIRA TURMA)

0000889-03.2011.5.15.0138 RO - RECURSO ORDINÁRIO

VARA DO TRABALHO DE JACAREÍ 2A

RECORRENTE: NESTLÉ BRASIL LTDA

RECORRIDO: CLAUDILENE RODRIGUES DA SILVA

RECORRIDO: OFICINA DO CACAU INDÚSTRIA E COMÉRCIO DE GÊNEROS

ALIMENTÍCIOS LTDA. EPP

JUIZ SENTENCIANTE: ROSANA FANTINI

LB

Inconformada com a r. sentença de fls. 150/154, cujo

relatório adoto e que julgou parcialmente procedente os pedidos, recorre ordinariamente a segunda reclamada argumentando, preliminarmente a ilegitimidade de parte. No mérito, aduz que não pode ser responsabilizada subsidiariamente pelas dívidas trabalhistas da primeira reclamada.

Depósito recursal e custas às fls. 167/168.

Contrarrazões da reclamante às fls. 174/178.

É o relatório.

\section{O T O}

Conheço do recurso, eis que presentes os pressupostos de admissibilidade.

A reclamante foi admitida pela primeira reclamada em 06/11/2007 para exercer a função de auxiliar de produção em prol da segunda reclamada, conforme anotação na CTPS (fls. 14/16). Foi dispensada por iniciativa patronal em 08/08/2011, sem receber as verbas rescisórias.

llegitimidade de parte. 
Sustenta a recorrente que é parte ilegítima para figurar no pólo passivo da demanda.

Todavia, entendo que a análise de eventuais responsabilidades é de natureza meritória, o que não enseja extinção do feito sem resolução de mérito.

Isto porque, segundo a teoria da asserção, ao apreciar as condições da ação, o órgão judicial analisa abstratamente os fatos alegados pelo autor, sem adentrar ao mérito.

Assim, rejeito a preliminar.

\section{Inépcia da petição inicial.}

No processo do trabalho, a petição inaugural pode conter tão somente uma breve exposição dos fatos, conforme se verifica no art. 840, § $1^{\circ}$, da CLT. Sendo assim, fornecendo o reclamante elementos suficientes ao julgador para decidir a causa, este há de fazê-lo, considerando todo o conjunto probatório, desde as alegações iniciais até os documentos colacionados aos autos.

Nesse sentido, já se posicionou a $3^{\circ}$ turma do E. TRT da 15ำ Região:

PETIÇÃO INICIAL. INÉPCIA. NÃO CONFIGURAÇÃO. INTELIGÊNCIA DOS ARTS. 840, § 1ㅇ, DA CLT E 282 E 295, PARÁGRAFO ÚNICO, DO CPC. Estando presentes os requisitos dos arts. 840, $\S 1^{\circ}$, da CLT e 282 do CPC, e inexistindo aqueles previstos no parágrafo único do art. 295 deste mesmo Código, não há que se falar em inépcia da petição inicial, impondo-se ao juízo sentenciante a apreciação meritória de todas as matérias ventiladas no exórdio. (Relator: LUÍS CARLOS CÂNDIDO MARTINS SOTERO DA SILVA. Processo 0000480-59.2010.5.15.0074 RO disponível a partir de $13 / 04 / 2012)$

Portanto, deixo de acolher a preliminar arguida.

Responsabilidade Subsidiária. 
Alega a segunda reclamada que não pode ser responsabilizada pelos débitos trabalhistas, uma vez que a atividade desenvolvida pelo reclamante não se confunde com terceirização, já que se trata contrato de industrialização e fornecimento sob encomenda de produtos e outras avenças, assemelhando-se à condição da dono da obra.

A r. sentença condenou a recorrente como responsável subsidiária pelas verbas trabalhistas, em virtude de contrato de prestação de serviços mantido entre as reclamadas (fls. 115/121), motivo pelo qual pugna pela reforma.

\section{Sem razão.}

Incontroverso que a primeira reclamada foi contratada pela segunda reclamada para a industrialização e fornecimento sob encomenda de algumas variedades de produtos alimentícios, com base nas especificações de propriedade ou desenvolvida pela segunda reclamada (fls. 115/121).

A cláusula décima do contrato de prestação de serviços entre as reclamadas deixa claro a exclusividade da prestação de serviços (fl. 119):

10.1 Tendo em vista o detalhado na cláusula 15.3, a "OFICINA DO CACAU" não poderá de nenhuma forma, seja diretamente ou por intermédio de sociedades afiliadas, ou por qualquer relação de fato, contratual, combinação ou associação empresarial, desenvolver, elaborar, fabricar, fornecer e vender os Produtos a terceiros. (...)

Portanto, incontroverso que a reclamante laborou em prol da segunda reclamada, mesmo que nas dependências da primeira reclamada.

A empresa contratante possui a obrigação de vigiar o cumprimento das obrigações trabalhistas da empresa. 
Assim sendo, atuou a segunda reclamada com culpa in vigilando, pois não se verifica, no contexto dos autos, que tenha fiscalizado de forma efetiva a empresa prestadora no cumprimento de suas obrigações trabalhistas, apenas beneficiando-se da mão de obra que tinha a oferecer.

Aplica-se ao caso o disposto na Súmula 331 do C. TST. Isto porque o que torna o tomador dos serviços responsável subsidiariamente é o inadimplemento dos créditos trabalhistas que decorrem da relação de emprego entre o trabalhador e o seu direto empregador:

CONTRATO DE PRESTAÇÃO DE SERVIÇOS. LEGALIDADE (nova redação do item IV e inseridos os itens V e VI à redação) - Res. 174/2011, DEJT divulgado em 27, 30 e 31.05.2011

(..)

IV - O inadimplemento das obrigações trabalhistas, por parte do empregador, implica a responsabilidade subsidiária do tomador dos serviços quanto àquelas obrigações, desde que haja participado da relação processual e conste também do título executivo judicial.

Também não socorre a eventual alegação de inconstitucionalidade da Súmula 331, IV, do C. TST. Isto porque, tal questão foi enfrentada nos autos da Reclamação 6970, ajuizada com fundamento na violação ao disposto na Súmula Vinculante n.o 10. Na ocasião, embora liminarmente tenha suspendido a aplicação do disposto no inciso IV, da Súmula 331 do C. TST, ao apreciar o mérito, em 15/04/2009, o relator Exmo. Ministro Levandowski julgou improcedente o pedido, conforme verificado no sítio do $\mathrm{E}$. STF. Assim, entendo que não houve afronta ao disposto no artigo $5^{\circ}$, II, da $\mathrm{CF} / 88$.

Portanto, o recorrente deve ser responsabilizado pelos direitos deferidos, de forma subsidiária, nos termos da Súmula 331, IV, do C. TST.

Esclareça-se que a responsabilidade em foco alcança todas e cada uma das parcelas trabalhistas que sejam devidas pela empresa intermediária, nada importando se as mesmas possuem caráter salarial ou 
indenizatório (por exemplo, verbas rescisórias, horas extras, multas dos artigos 477 e 467 da CLT). Cuida-se aqui um ônus que deve suportar o recorrente por contratar uma pessoa jurídica sem suficiente idoneidade econômico/financeira, agindo, também, com culpa in eligendo. A questão inclusive foi pacificada pelo C. TST, com a inclusão do inciso IV à Súmula 331, razão pela qual não verifico afronta ao art. 5ำ XLV da Constituição Federal.

Entendo, assim, verificada aí mais uma razão para justificar a aplicação da responsabilidade subsidiária à recorrente, mormente se atentarmos para os termos do dispositivo constitucional acima citado e do artigos 927 c/c o artigo 186 do Código Civil.

Ademais, a cláusula terceira do contrato social da Nestlé deixa claro seu objetivo social (fl. 97):

CLÁUSULA TERCEIRA - A sociedade tem por objetivo a fabricação, transformação, beneficiamento, conservação, estocagem, distribuição, importação, exportação, comércio e divulgação d: a) produtos alimentícios e bebidas em geral; b) matérias-primas utilizadas no fabrico de alimentos e bebidas; (...)

Nota-se portanto que a primeira reclamada realizava prestação de serviços para atividade fim da segunda reclamada, sendo aplicável ao presente caso inciso I da Súmula 331 do C. TST, caso houvesse pedido.

Deste modo, mantenho incólume a decisão de origem.

\section{Aplicação do art. 460 do CPC.}

O art. 128 do CPC, corolário do Princípio da Congruência, dispõe sobre a necessidade de correspondência entre demanda e sentença. Portanto, o julgador está vinculado ao pedido apresentado na peça inicial, sendo-lhe defeso conceder mais, menos ou coisa diversa da postulada (art. $460 \mathrm{CPC})$. 
A sentença extra e citra petita viola o princípio da inafastabilidade da jurisdição, insculpido no artigo 5ํ, XXXV da Constituição Federal, pois qualquer pedido expressamente formulado pelas partes deve ser analisado na sentença (seja para acolhê-lo ou não), nos exatos limites daquilo que foi proposto. A prestação jurisdicional que desrespeita os parâmetros da lide constitui flagrante nulidade, passível de conhecimento pelo Tribunal, inclusive de ofício, tendo em vista tratar-se de matéria processual de ordem pública.

Assim, considerando que a sentença condenou o autor ao pagamento de $\mathrm{R} \$ 1.192,00$ a título de multa de $40 \%$ sobre o FGTS e o pedido foi limitado ao valor de $\mathrm{R} \$ 1.098,85$, reformo a sentença neste particular.

\section{Honorários Advocatícios.}

No processo trabalhista, consubstanciado no entendimento das Súmulas 219 e 329, do C. TST, os honorários advocatícios somente são devidos quando preenchidos os requisitos do art. 14, da Lei $5.584 / 70$, os quais não estão presentes nos autos, uma vez que o reclamante não está assistido pelo sindicato de sua categoria profissional.

No mais, entendo que os artigos 389 e 404 do Código Civil são normas de caráter geral e, portanto, são incapazes de revogar preceito especial contido na norma trabalhista.

Destarte, reformo o julgado de origem para excluir da condenação as verbas deferidas a título de honorários advocatícios.

\section{Multa 475-J do CPC.}

O MM. Juízo "a quo" determinou que o pagamento do débito apurado será feito na forma do artigo 475-J do CPC. Contra essa 
decisão, insurge-se a recorrente. Pleiteia que eventual execução contra a segunda reclamada ocorra nos moldes do capítulo $\mathrm{V}$ da CLT.

No tocante à aplicação do artigo 475-J da CLT entendo que a nova sistemática criada pela Lei 11.232/05 não é aplicável ao processo trabalhista, que possui regras próprias nos artigos 880 e seguintes da CLT. Inexiste, portanto, omissão que justifique a aplicação subsidiária do processo comum, inclusive no tocante ao regramento do cumprimento de sentença.

Neste sentido, aresto do C. TST:

MULTA DO ART. 475-J DO CPC. INAPLICABILIDADE NO PROCESSO DO TRABALHO. A aplicação subsidiária do Código de Processo Civil ao Direito Processual do Trabalho, de acordo com a doutrina e com a jurisprudência unânimes, exige dois requisitos para permitir a aplicação da norma processual comum ao Processo do Trabalho: a ausência de disposição na CLT e a compatibilidade da norma supletiva com os princípios do Processo do Trabalho. Observa-se que o fato preconizado pelo art. 475-J do CPC possui disciplina própria no âmbito do Processo do Trabalho, pelos arts. 880, 882 e 883 da CLT, que prevêem o prazo e a garantia da dívida por depósito ou a penhora de bens quantos bastem ao pagamento da importância da condenação, acrescido das despesas processuais, custas e juros de mora. Decisão em sentido contrário merece ser modificada. Recurso de Revista parcialmente conhecido e provido.

(RR - 71600-72.2006.5.17.0002, Relatora Ministra: Maria de Assis Calsing, Data de Julgamento: 17/08/2011, 4a Turma, Data de Publicação: 26/08/2011)

\section{Contudo, curvo-me ao entendimento majoritário desta}

E. Turma, que reiteradamente se manifestou neste sentido e mantenho o julgado de origem quanto à incidência da multa do art. 475-J, do CPC.

\section{Compensação.}

Indefiro o pedido de compensação, pois não há nos autos comprovação que alguma verba rescisória tenha sido paga.

\section{DIANTE DO EXPOSTO, DECIDO:}


DISPOSITIVO>conhecer do recurso de NESTLÉ BRASIL LTDA. o prover em parte, para nos termos da fundamentação, a) excluir a condenação à título de honorários advocatícios; b) limitar o valor da multa de $40 \%$ sobre o FGTS a $R \$$ $1.098,85$. Custas pela reclamada no valor de $R \$ 200,00$, atribuidos ao novo valor da condenação de $\mathrm{R} \$ 12.000,00$. </DISPOSITIVO>

ANTONIA REGINA TANCINI PESTANA

Desembargadora Relatora 
ANEXO 4 - acórdão autos n 0016200-96.2009.5.15.0140 


\section{ACÓRDÃO No \\ PROCESSO TRT/CAMPINAS n \\ 0016200-96.2009.5.15.0140 \\ RECURSO ORDINÁRIO \\ RECORRENTE : ROSELI APARECIDA MARTINS \\ RECORRIDO \\ : HBR INDÚSTRIA E COMÉRCIO DE CALÇADOS \\ LTDA. - EPP \\ RECORRIDO \\ : SAFETLINE EQUIPAMENTOS DE SEGURANÇA LTDA.}

ORIGEM

: VARA DO TRABALHO DE ATIBAIA

Inconformada com a r. sentença de fls. 526/534, que julgou procedentes em parte os pedidos, a reclamante interpõe o recurso ordinário de fls. 568/581.

Sustenta, em síntese, ser a segunda reclamada responsável solidária pelos débitos trabalhistas apurados, tendo em vista ser tomadora exclusiva dos serviços prestados pela primeira ré, afeitos à sua atividade-fim. Afirma não ter sido celebrado entre as demandadas contrato de facção, pois a empregadora não contava com tecnologia própria para produção de sapatos e dependia financeiramente da segunda reclamada. Requer, subsidiariamente, a responsabilização subsidiária desta ré, nos moldes da Súmula n. ${ }^{\circ} 331$ do C. TST. Por fim, pleiteia a exclusão de multa por oposição de embargos de declaração protelatórios.

Contrarrazões da primeira reclamada às fls. 586/620; da segunda reclamada, às fls. 635/660, alegando intempestividade do apelo.

Os autos não foram remetidos ao Ministério Público do Trabalho. 


\section{O T O}

\section{$\underline{1 \text { - Conhecimento }}$}

A reclamante foi intimada do teor da sentença em 10 de maio de 2010 (fl. 535). Em 14 de maio do mesmo ano, opôs tempestivamente embargos de declaração (fls. 552/555).

O Juízo de origem conheceu os embargos, julgandoos improcedentes, por entender não se destinarem ao saneamento de qualquer omissão ou contradição mas, sim, à reforma, no mérito, do decisum (fls. 565/566). A reclamante foi intimada de tal decisão em 10 de setembro de 2010 (fl. 567).

Diferentemente do alegado pela segunda reclamada, os embargos de declaração conhecidos e não providos interrompem, sim, o prazo para interposição de recurso ordinário, nos termos do artigo 538 do CPC. Na hipótese em tela, a reclamante protocolou o apelo em 17/09/2010, sete dias após tomar conhecimento da decisão proferida em embargos de declaração. Portanto, é tempestiva a medida.

Assim sendo, presentes os pressupostos de admissibilidade, conheço o recurso, exceto quanto à pretensão de exclusão de multa por oposição de embargos de declaração procrastinatórios, por falta de interesse recursal, já que a penalidade não foi imposta pelo Juízo de origem.

\section{$\underline{2 \text { - Mérito }}$}

Resume-se o recurso à análise da responsabilidade solidária ou subsidiária - da segunda ré quanto aos débitos trabalhistas apurados na presente reclamação.

Em primeiro lugar, remarca-se não haver inovação da lide, ao contrário do aduzido pela reclamada Safetline em contrarrazões.

A reclamante, em sua preambular, pleiteia expressamente a condenação subsidiária da segunda reclamada. $\mathrm{O}$ fato de 
ter aditado a inicial, para fazer constar também pedido de responsabilização solidária da ré, não exclui, automaticamente, aquele primeiro pleito, que persiste na forma de pedido subsidiário.

Portanto, possível o exame, no mérito, das irresignações formuladas pela autora.

Feitas tais considerações, importa verificar se houve ou, não, celebração de contrato de facção entre as partes demandadas.

O contrato de facção, tipicamente empresarial, dotase de natureza híbrida, assumindo caracteres ora do contrato de terceirização de mão de obra, ora do contrato de empreitada. Em regra, implica a atribuição à contratada de parcela da atividade industrial da contratante, obrigando-se aquela à fornecer a esta produtos prontos e acabados, afeitos à sua atividade-fim.

Na hipótese em tela, a segunda reclamada, Safetline, assevera ter celebrado verbalmente contrato de facção com a primeira ré, HBR. Todavia, a prova dos autos não aponta em tal direção, como sustentado pela reclamante em seu recurso ordinário.

Com efeito, o preposto da primeira reclamada, depondo nos autos do processo . $^{\circ}$ 1993/2008, tramitado perante a $1^{\text {a }}$ Vara do Trabalho de Atibaia, esclareceu que:

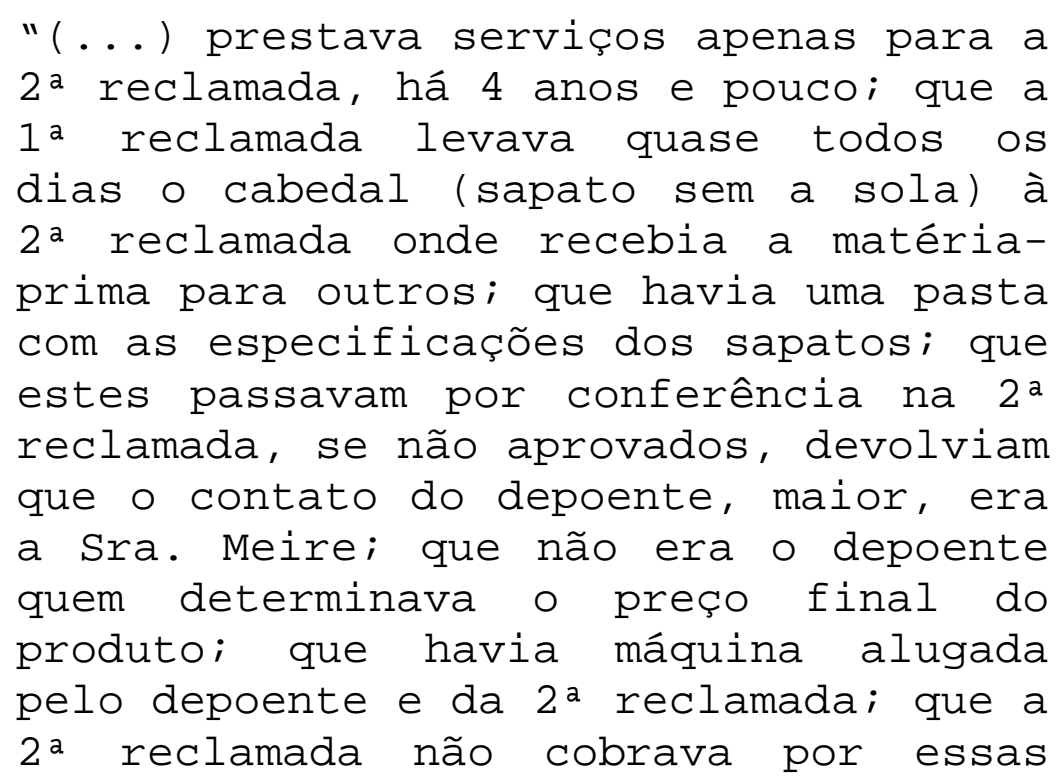


máquinas; que o depoente assim como funcionários receberam treinamentos na $2^{\text {a }}$ reclamada; (...) que o Sr. Jorge esteve na $1^{\text {a }}$ reclamada e falou com os funcionários, pedindo a colaboração, dizendo que não iria faltar serviço e que o salário seria acertado até dezembro (...)" (sic - fl. 442).

A testemunha Célia Maria da Silva, depoente nos autos supracitados, confirmou a versão do preposto da primeira ré, aludindo que:

"(..) a $1^{a}$ reclamada prestava
serviços para a $2^{a}$, somente; que
recebia ordens do Sr. Flávio, e quando
este não estava, recebia da Sra.
Meire; que o Sr. Jorge esteve na $1^{a}$
reclamada no final do ano; que o Sr.
Jorge disse que acertaria os
atrasados, que nada faltaria aos
funcionários (...); que a matéria-
prima era da 2 a reclamada; que a
depoente Sra. Meire algumas vezes na
la reclamada; (...) que a Sra. Meire
ia ver se o serviço estava certo; que
foi na sede da 2 a reclamada para
verificar como o sapato deveria ser
feito; que ao que sabe a Bs é uma
fábrica que faliu há muitos anos;
(...) que a $1^{a}$ reclamada não possui
estrutura para fabricar o sapato
inteiro (...)" (sic - fl. 442).

E ainda a testemunha Antonio Aparecido Goes

expôs que:

"(..) a $1^{\text {a }}$ reclamada prestava serviços somente à $2^{a} ;$ que pessoas da $2^{a}$ reclamada vinham na $1^{\text {a }}$ reclamada para 


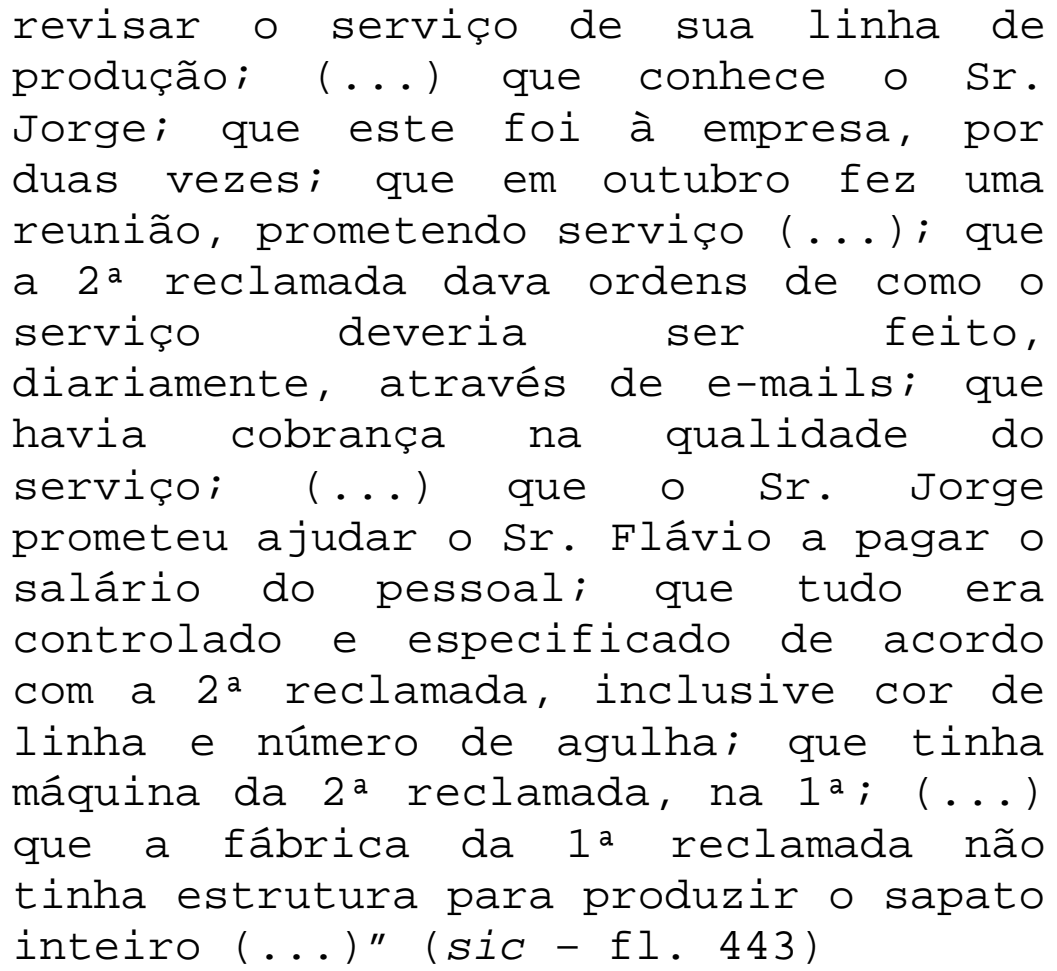

Os mesmos fatos são relatados pelas testemunhas Zafira Minervina Santana (fl. 443), Lucelia Antonio Pinheiro Leite (fl. 444) e José Vicente Pestana Ribela (fl. 444), depoentes nos autos n. ${ }^{\circ}$ 1993/2008, pela testemunha Hercilia Machado Gonçalves (fl. 452), depoente nos autos n. ${ }^{\circ}$ 154/2009 e pela testemunha Alexandre Cabral Fernandes (fls. 454 e 456), depoente nos autos n. ${ }^{\circ} 149 / 2009$.

A única narrativa destoante é a de Meire Aparecida Briante Peres (fl. 485), que afirma não haver contrato de exclusividade entre as demandadas. Suas palavras, porém, não podem prevalecer, diante da farta prova testemunhal que lhes é contrária.

Do exposto, entrevê-se que:

(a) a primeira reclamada, HBR, produzia cabedais (sapatos sem sola) exclusivamente para a segunda ré, Safetline;

(b) a Safetline ingeria nos negócios da HBR, tecendo exigências técnicas diretamente associadas ao modo de produção dos cabedais comprados; 
(c) a Safetline fornecia tecnologia e maquinário à HBR para fabricação dos produtos que comprava com exclusividade;

(d) a Safetline oferecia treinamento aos empregados da HBR.

Não fossem suficientes as provas da ingerência, foi comprovado ter o sócio da Safetline, segunda reclamada, comparecido à HBR, primeira reclamada, para tratar diretamente com os empregados desta última o aumento dos níveis de produção, comprometendo-se a assisti-los inclusive para o pagamento de seus salários em atraso.

Saliente-se, no mais, que todos estes fatos foram demonstrados também documentalmente. Os e-mails de fls. 99/102, 104/110, 116/167 evidenciam a coordenação das atividades industriais das demandadas. As notas de fls. 111/115 corroboram o fornecimento de tecnologia à HBR para a produção dos cabedais. As fichas de fls. 190/200, por fim, apontam as especificações técnicas à que a primeira reclamada se submetia.

Todos esses elementos indicam não a existência de um contrato de facção, mas a verdadeira terceirização mascarada de parte da produção industrial da segunda reclamada.

O entendimento é corroborado pelo fato de não haver prova documental do alegado contrato de facção. Ora, não se pode admitir prova exclusivamente testemunhal de um contrato que, certamente, por suas características empresariais, teria valor superior a dez salários mínimos, consoante previsto no artigo 402 do Código de Processo Civil. Por outro lado, é inacreditável que uma avença de tal monta não tenha sido formalizada entre as partes, o que é de praxe no meio industrial.

Ressalte-se, por fim, que a nota fiscal de venda de um sapato "BS", alegadamente produzido pela primeira reclamada, não mitiga a tese da exclusividade na prestação de serviços (fl.426). Isso porque, como esclarecido pela testemunha Lucélia Antonio Pinheiro Leite, a HBR forneceu, de fato, produtos para a "BS", porém muitos anos antes da prestação de serviços exclusiva à Safetline (fl. 424). Nada impediria, pois, que um par de sapatos remanescente daquela época, ou embalado em 
caixa antiga, tivesse sido vendido em 2009, o que originaria o aludido documento fiscal.

Por conseguinte, em face de todos os argumentos explanados, reputa-se não configurado o contrato de facção, reconhecendose a celebração, entre as rés, de contrato de prestação de serviços, para terceirização de mão de obra.

Nesse contexto, considerada a evidente culpa in vigilando da tomadora dos serviços, e em face do inadimplemento de diversas obrigações trabalhistas pela intermediadora de mão de obra, impõe-se a responsabilização subsidiária da segunda reclamada pelos débitos trabalhistas apurados na presente demanda, nos termos da Súmula n. ${ }^{\circ} 331$, IV, do C. TST.

Nesse mesmo sentido, e em caso relativo às mesmas reclamadas, já decidiu este E. Tribunal:

\begin{tabular}{l} 
"Desta feita, evidente está que não há \\
que se falar em mero contrato de \\
facção, diante dos requisitos que \\
demonstram uma real intermediação de \\
mão-de-obra para a realização de \\
atividade fim, com a finalidade de \\
eliminar o custo de mão-de-obra e \\
eximir-se das obrigações trabalhistas \\
que tocariam à segunda recorrida, caso \\
fosse a real empregadora dos \\
funcionários da primeira ré. \\
Restou claro, portanto, que a segunda \\
reclamada é a real beneficiária direta \\
do produto do trabalho dos empregados \\
da primeira reclamada. \\
De sorte que o apelo da reclamante \\
deve ser acolhido para que a sentença \\
seja modificada a fim de condenar a \\
segunda reclamada subsidiariamente por \\
todos os créditos já deferidos na \\
\hline origem." (TRT15, Proc. n. $0015800-$ \\
82.2009.5.15.0140 Ro, rel. Juiz Manoel \\
Carlos Toledo Filho, DJ 15/04/2001) \\
[grifos nossos]
\end{tabular}


Por fim, destaque-se não ser a responsabilização solidária da demandada possível, pois não foi requerido o reconhecimento de vínculo empregatício diretamente com a segunda ré, não havendo outro fundamento legal a embasar o pedido.

Pelo exposto, decide-se conhecer o recurso ordinário da reclamante e, no mérito, dar-lhe provimento, para condenar subsidiariamente a segunda reclamada nos débitos trabalhistas apurados na presente reclamação. Valor da condenação mantido.

JOSÉ PEDRO DE CAMARGO RODRIGUES DE SOUZA

Juiz Relator 
ANEXO 5 - Projeto de Lei $n^{\circ}$ 4.302/98 
PROJETO TRT LET No 4.301 TE 1998

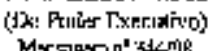

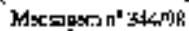

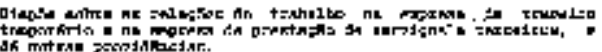

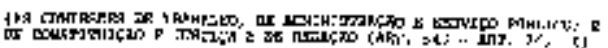

OCostam:

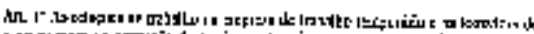

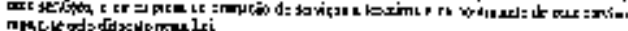

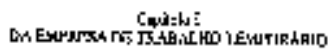

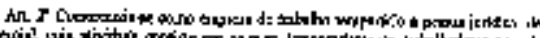

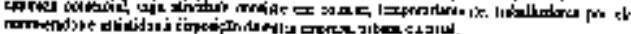

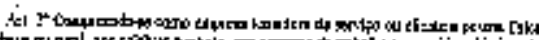

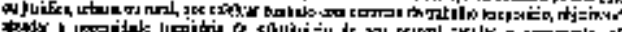

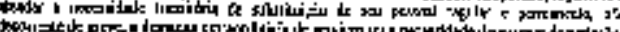

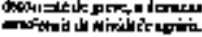

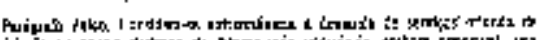

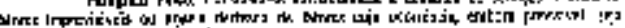
1

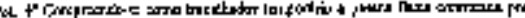
Coger

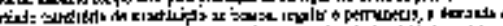

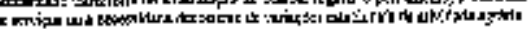

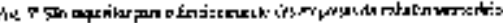

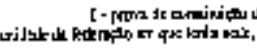

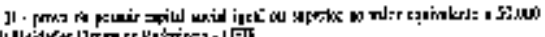

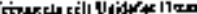

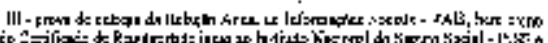

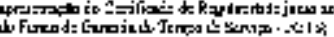

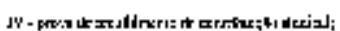

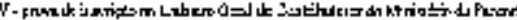

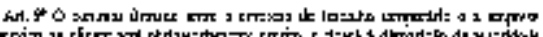

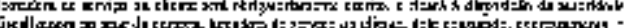

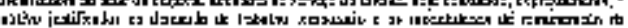

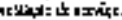

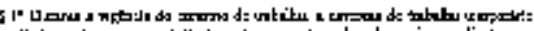

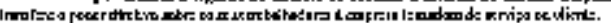

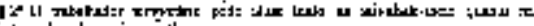

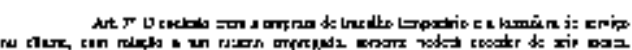

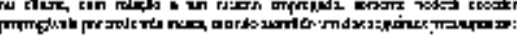

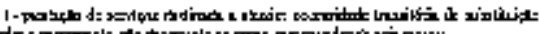

ח- ח

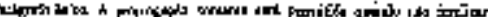

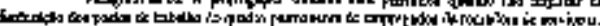

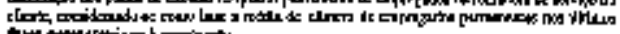

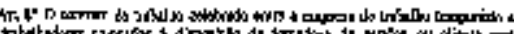

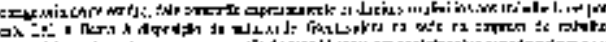
Xirotion

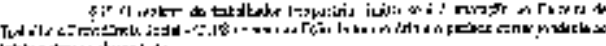

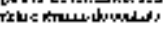

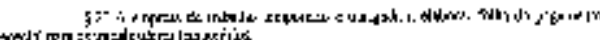

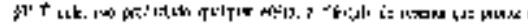

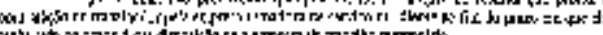

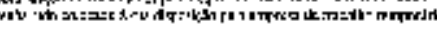

ill

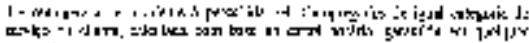

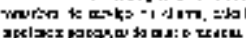

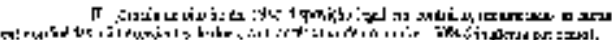

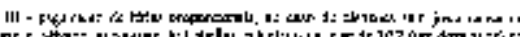

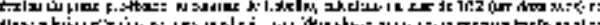

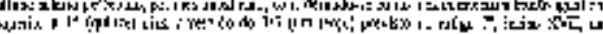

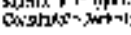

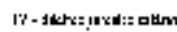

i-1; 1;

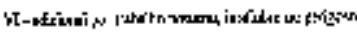

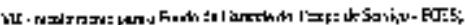

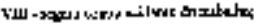

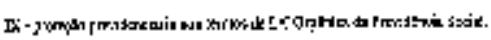

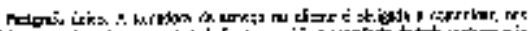

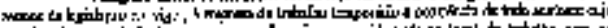

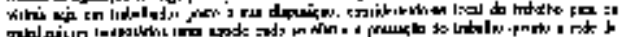

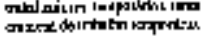

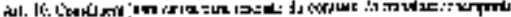

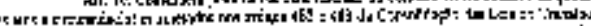

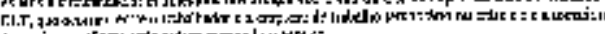

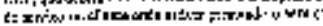

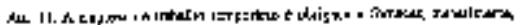

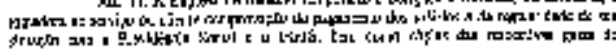
modrsed:

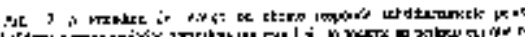

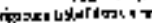

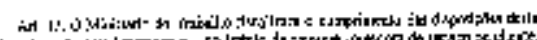
1. 1 y

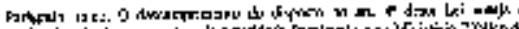

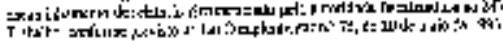

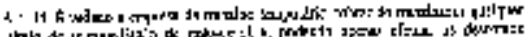

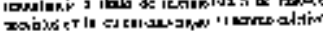

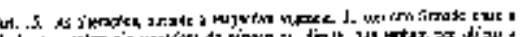

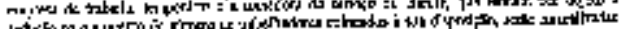
N

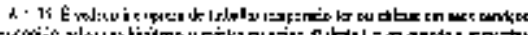

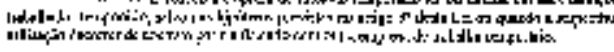

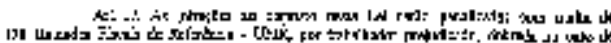

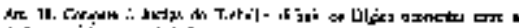

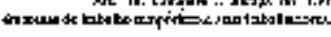




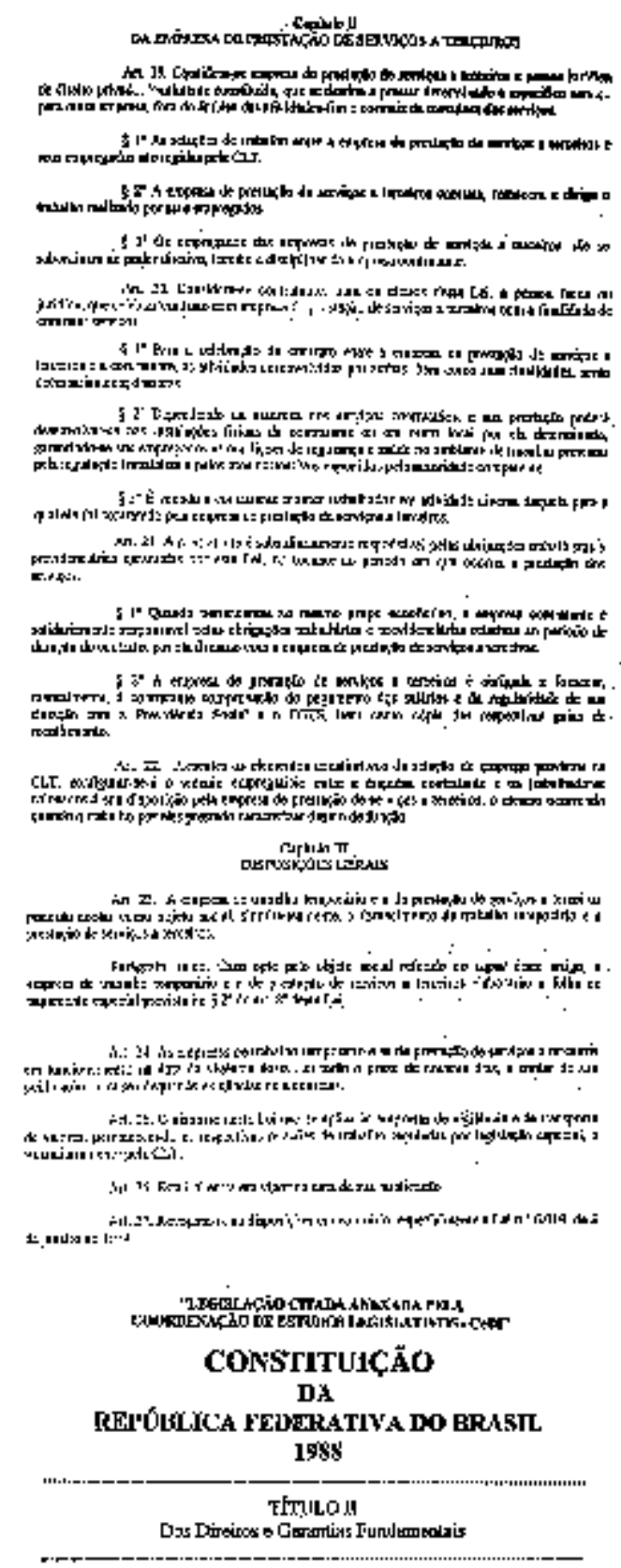

CAPTILOI

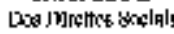

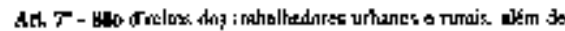

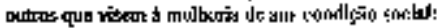

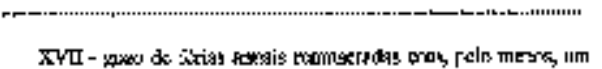

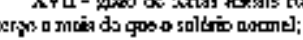

-

Tiтนо Гi

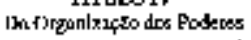

crittion

ix) foder Loginatio

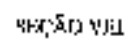

Do J'rocess-Laxigiation

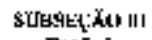

תha Liv

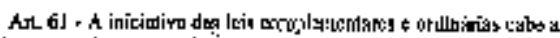

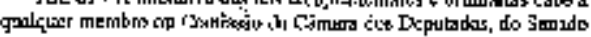

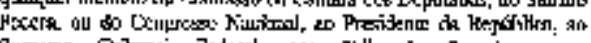

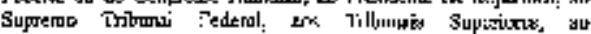

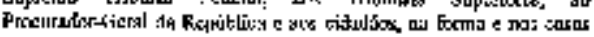

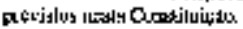

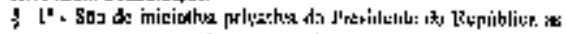
kls que:

j- lisem uu modi

$\pi$. dismonhum sobre:

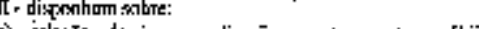

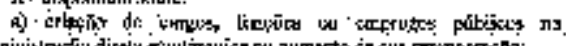

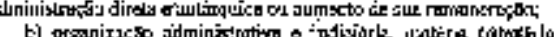

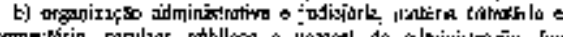

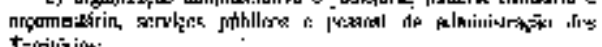
t=órilīiôti

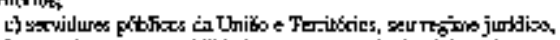

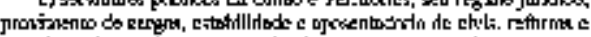

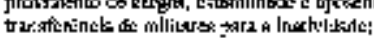

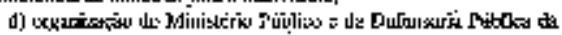

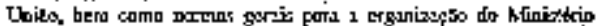

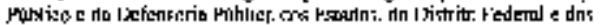
Trxilitrivdi

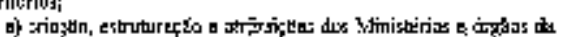

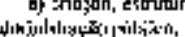

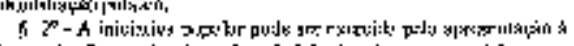

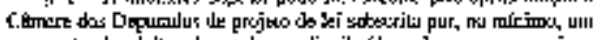

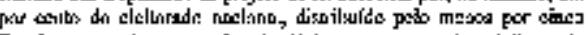

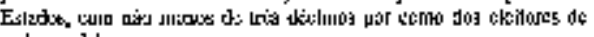
cods seir \&elo.

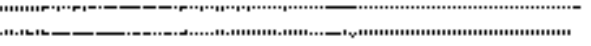

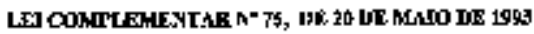

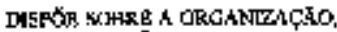
AS ATRIRUITLEYX E O HSCATUTO

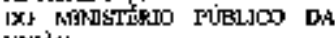
LNrits. 
ANEXO 6 - Projeto de Lei $n^{\circ}$ 4.330/2004 


\section{PROJETO DE LEI No}

, DE 2004

\section{(Do Sr. Sandro Mabel)}

Dispõe sobre o contrato de prestação de serviço a terceiros e as relações de trabalho dele decorrentes.

O Congresso Nacional decreta:

Art. $1^{\circ}$ Esta Lei regula o contrato de prestação de serviço e as relações de trabalho dele decorrentes, quando o prestador for sociedade empresária que contrate empregados ou subcontrate outra empresa para a execução do serviço.

Parágrafo único. Aplica-se subsidiariamente ao contrato de que trata esta Lei o disposto no Código Civil, em especial os arts. 421 a 480 e 593 a 609.

Art. $2^{\circ}$ Empresa prestadora de serviços a terceiros é a sociedade empresária destinada a prestar à contratante serviços determinados e específicos.

$\S 1^{\circ}$ A empresa prestadora de serviços contrata e remunera o trabalho realizado por seus empregados, ou subcontrata outra empresa para realização desses serviços.

$\S 2^{\circ}$ Não se configura vínculo empregatício entre a empresa contratante e os trabalhadores ou sócios das empresas prestadoras de serviços, qualquer que seja o seu ramo.

Art. $3^{\circ}$ São requisitos para o funcionamento da empresa de prestação de serviços a terceiros:

I - prova de inscrição no Cadastro Nacional de Pessoa Jurídica (CNPJ);

II - registro na Junta Comercial;

III - capital social compatível com o número de empregados, observando-se os seguintes parâmetros:

a) empresas com até dez empregados: capital mínimo de $\mathrm{R} \$ 10.000,00$ (dez mil reais);

b) empresas com mais de dez e até vinte empregados: capital mínimo de $\mathrm{R} \$ 25.000,00$ (vinte e cinco mil reais);

c) empresas com mais de vinte e até cinqüenta empregados: capital mínimo de $\mathrm{R} \$ 45.000,00$ (quarenta e cinco mil reais);

d) empresas com mais de cinqüenta e até cem empregados: capital mínimo de $\mathrm{R} \$ 100.000,00$ (cem mil reais); e e) empresas com mais de cem empregados: capital mínimo de $\mathrm{R} \$ 250.000,00$ (duzentos e cinqüenta mil reais).

$\S 1^{\circ}$ Convenção ou acordo coletivo de trabalho podem exigir a imobilização do capital social em até cinqüenta por cento dos valores previstos no inciso III deste artigo.

$\S 2^{\circ} \mathrm{O}$ valor do capital social de que trata o inciso III deste artigo será reajustado:

I - no mês de publicação desta lei, pela variação acumulada do Índice Nacional de Preços ao Consumidor (INPC), da Fundação Instituto Brasileiro de Geografia e Estatística (IBGE), 
verificada de novembro de 2004, inclusive, ao mês imediatamente anterior ao do início de vigência desta lei;

II - anualmente, a partir do ano subseqüente ao do reajuste mencionado no inciso anterior, no mês correspondente ao da publicação desta lei, pela variação acumulada do INPC nos doze meses imediatamente anteriores.

Art. $4^{\circ}$ Contratante é a pessoa física ou jurídica que celebra contrato de prestação de serviços determinados e específicos com empresa prestadora de serviços a terceiros.

$\S 1^{\circ}$ É vedada à contratante a utilização dos trabalhadores em atividades distintas daquelas que foram objeto do contrato com a empresa prestadora de serviços.

$\S 2^{\circ} \mathrm{O}$ contrato de prestação de serviços pode versar sobre o desenvolvimento de atividades inerentes, acessórias ou complementares à atividade econômica da contratante.

Art. $5^{\circ}$ São permitidas sucessivas contratações do trabalhador por diferentes empresas prestadoras de serviços a terceiros, que prestem serviços à mesma contratante de forma consecutiva.

Art. $6^{\circ}$ Os serviços contratados podem ser executados no estabelecimento da empresa contratante ou em outro local, de comum acordo entre as partes.

Art. $7^{\circ}$ É responsabilidade da contratante garantir as condições de segurança e saúde dos trabalhadores, enquanto estes estiverem a seu serviço e em suas dependências, ou em local por ela designado.

Art. $8^{\circ}$ Quando o empregado for encarregado de serviço para o qual seja necessário treinamento específico, a contratante deverá:

I - exigir da empresa prestadora de serviços a terceiros certificado de capacitação do trabalhador para a execução do serviço; ou

II - fornecer o treinamento adequado, somente após o qual poderá ser o trabalhador colocado em serviço.

Art. $9^{\circ}$ A contratante pode estender ao trabalhador da empresa de prestação de serviços a terceiros benefícios oferecidos aos seus empregados, tais como atendimento médico, ambulatorial e de refeição destinado aos seus empregados, existentes nas dependências da contratante ou local por ela designado.

Art. 10. A empresa contratante é subsidiariamente responsável pelas obrigações trabalhistas referentes ao período em que ocorrer a prestação de serviços, ficando-lhe ressalvada ação regressiva contra a devedora.

Parágrafo único. Na ação regressiva de que trata o caput, além do ressarcimento do valor pago ao trabalhador e das despesas processuais, acrescidos de juros e correção monetária, é devida indenização em valor equivalente à importância paga ao trabalhador. 
Art. 11. A empresa prestadora de serviços a terceiros, que subcontratar outra empresa para a execução do serviço, é solidariamente responsável pelas obrigações trabalhistas assumidas pela empresa subcontratada.

Art. 12. Nos contratos de prestação de serviços a terceiros em que a contratante for a Administração Pública, a responsabilidade pelos encargos trabalhistas é regulada pelo art. 71 da Lei $n^{\circ} 8.666$, de 21 de junho de 1993.

Art. 13. O recolhimento das contribuições previdenciárias relativas aos trabalhadores contratados para a prestação de serviços a terceiros observa o disposto no art. 31 da Lei $n^{\circ}$ 8.212 , de 24 de julho de 1991.

Art. 14. O contrato de prestação de serviços a terceiros deve conter, além das cláusulas inerentes a qualquer contrato:

I - a especificação do serviço a ser prestado;

II - o prazo para realização do serviço, quando for o caso;

III - a obrigatoriedade de apresentação periódica, pela empresa prestadora de serviços a terceiros, dos comprovantes de cumprimento das obrigações trabalhistas pelas quais a contratante é subsidiariamente responsável.

Art. 15. O recolhimento da contribuição sindical prevista nos arts. 578 e seguintes da Consolidação das Leis do Trabalho (CLT) deve ser feito ao sindicato representante da categoria profissional correspondente à atividade exercida pelo trabalhador na empresa contratante.

$\S 1^{\circ}$ A contribuição sindical devida pelo trabalhador de empresa de prestação de serviços a terceiros, contratado para o cumprimento do contrato de que trata esta Lei, é proporcional ao período em que foi colocado à disposição da empresa contratante e consiste na importância correspondente a um doze avos da remuneração de um dia de trabalho por mês de serviço ou fração superior a quatorze dias.

$\S 2^{\circ}$ Não é devida a contribuição pelo trabalhador se este já houver pago, no mesmo ano, a título de contribuição sindical, importância correspondente à remuneração de um dia de trabalho, nos termos do art. 582 da CLT.

Art. 16. O disposto nesta Lei não se aplica:

I - à prestação de serviços de natureza doméstica, assim entendida aquela fornecida à pessoa física ou à família no âmbito residencial destas;

II - às empresas de vigilância e transporte de valores, permanecendo as respectivas relações de trabalho reguladas por legislação especial.

Art. 17. O descumprimento do disposto nesta Lei sujeita a empresa infratora ao pagamento de multa administrativa de $\mathrm{R} \$ 500,00$ (quinhentos reais) por trabalhador prejudicado, salvo se já houver previsão legal de multa específica para a infração verificada.

$\S 1^{\circ}$ A fiscalização, a autuação e o processo de imposição de multas reger-se-ão pelo Título VII da CLT. 
$\S 2^{\circ}$ As partes ficam anistiadas das penalidades não compatíveis com esta Lei, impostas com base na legislação anterior.

Art. 18. Os contratos em vigência serão adequados aos termos desta Lei no prazo de cento e vinte dias a partir da vigência.

Art. 19. Esta Lei entra em vigor trinta dias após a publicação.

\section{JUSTIFICAÇÃO}

O mundo assistiu, nos últimos 20 anos, a uma verdadeira revolução na organização da produção. Como conseqüência, observamos também profundas reformulações na organização do trabalho. Novas formas de contratação foram adotadas para atender à nova empresa.

Nesse contexto, a terceirização é uma das técnicas de administração do trabalho que têm maior crescimento, tendo em vista a necessidade que a empresa moderna tem de concentrar-se em seu negócio principal e na melhoria da qualidade do produto ou da prestação de serviço.

No Brasil, a legislação foi verdadeiramente atropelada pela realidade. Ao tentar, de maneira míope, proteger os trabalhadores simplesmente ignorando a terceirização, conseguiu apenas deixar mais vulneráveis os brasileiros que trabalham sob essa modalidade de contratação.

As relações de trabalho na prestação de serviços a terceiros reclamam urgente intervenção legislativa, no sentido de definir as responsabilidades do tomador e do prestador de serviços e, assim, garantir os direitos dos trabalhadores.

A presente proposição tem origem no Projeto de Lei $n^{\circ} 4.302$, de 1998, que após mais de cinco anos de tramitação, teve a retirada solicitada pelo Poder Executivo. Ressalta-se que durante a tramitação do Projeto de Lei do Executivo, que também alterava a lei do trabalho temporário, travaramse longos e frutíferos debates sobre o tema, tanto nesta Casa quanto no Senado Federal, que muito enriqueceram a proposta original.

O Projeto de Lei que ora apresentamos exclui os dispositivos que tratavam do trabalho temporário, limitando-se à prestação de serviços a terceiros, e incorpora as contribuições oferecidas por todos os que participaram dos debates do Projeto de Lei n 4.302, de 1998.

A nossa proposição regula o contrato de prestação de serviço e as relações de trabalho dele decorrentes. O prestador de serviços que se submete à norma é, portanto, a sociedade empresária, conforme a nomenclatura do novo Código Civil, que contrata empregados ou subcontrata outra empresa para a prestação de serviços.

Deve ser destacada a definição da empresa prestadora de serviços como aquela que presta serviços determinados e específicos para a empresa contratante. É a prestadora responsável pela contratação, remuneração e direção do trabalho de seus empregados, podendo, ainda, subcontratar outras empresas para realizar os serviços contratados.

Não há, obviamente, vínculo empregatício entre a tomadora de serviços e os trabalhadores contratados pela prestadora ou seus sócios. 
São estabelecidos requisitos para o funcionamento das empresas prestadoras de serviço que visam a garantir o adimplemento das obrigações trabalhistas e previdenciárias. O capital social mínimo estipulado em função do número de empregados é um exemplo.

É prevista, ainda, a possibilidade de ser exigida a imobilização de até $50 \%$ do capital social da prestadora de serviços mediante acordo ou convenção coletiva de trabalho.

A nossa proposição define também a figura do contratante que pode ser pessoa física ou jurídica. A inclusão de pessoa física justifica-se pela necessidade de permitir a contratação de prestadoras de serviço por profissionais liberais.

Vários dispositivos estipulam limitações contratuais que protegem o trabalhador, como a vedação de sua utilização, pela empresa contratante, em atividades diversas das estipuladas em contrato com a empresa prestadora de serviços.

O objeto da contratação deve ser especificado. É, no entanto, amplo, podendo versar sobre atividades inerentes, acessórias ou complementares à atividade econômica da contratante.

Uma das situações que muito nos preocupou foi a possibilidade de um trabalhador continuar prestando serviços a uma empresa contratante, ainda que se sucedam várias empresas prestadoras de serviço.

Optamos por abordar o tema no art. $5^{\circ}$, permitindo a continuidade do trabalho para a mesma empresa contratante.

A empresa contratante é diretamente responsável pelas condições de segurança e saúde do ambiente de trabalho.

Além disso, caso seja necessário treinamento específico para a realização do trabalho, a empresa contratante pode exigir da prestadora o certificado de capacitação do trabalhador ou pode fornecer o treinamento adequado.

Uma das maiores críticas que se faz à terceirização é a precarização das relações de trabalho dela decorrentes, apresentando altos índices de acidentes do trabalho. Atribuir a responsabilidade à contratante por esse aspecto ligado às condições de trabalho representa uma garantia ao trabalhador e, certamente, contribui para a melhoria do ambiente laboral.

É prevista a responsabilidade subsidiária da contratante quanto às obrigações trabalhistas, sendo-lhe assegurado, obviamente, o direito de ação regressiva contra a prestadora de serviços / devedora.

O projeto inova ao assegurar mediante a ação regressiva, além do ressarcimento dos valores pagos pela contratante, o pagamento de uma indenização equivalente ao valor pago ao trabalhador.

Há, ainda, previsão de responsabilidade solidária quanto às obrigações trabalhistas pela empresa prestadora de serviços que subcontratar outra empresa.

No caso de contratação com a Administração Pública, o projeto remete à Lei n ${ }^{\circ}$ 8.666, de 21 de junho de 1993, que "regulamenta o artigo 37, inciso XXI, da Constituição Federal, institui normas para licitações e contratos da Administração Pública e dá outras providências". 
Isso significa que a Administração Pública é solidariamente responsável quanto aos encargos previdenciários, mas não quanto às dívidas trabalhistas.

O contrato de prestação de serviços deve conter a especificação do serviço a ser prestado e o prazo para a sua realização. Deve, além disso, prever a apresentação periódica, pela empresa prestadora de serviços, dos comprovantes de cumprimento das obrigações trabalhistas, o que

possibilitará a fiscalização por parte da empresa contratante.

Outro aspecto relevante da proposição é que o recolhimento da contribuição sindical compulsória deve ser feito à entidade representante da categoria profissional correspondente à atividade terceirizada.

Aumenta-se, dessa forma, o poder de negociação com as entidades patronais, bem como é favorecida a fiscalização quanto à utilização correta da prestação de serviços.

São excluídas da aplicação da lei as atividades de empregado doméstico, e ainda as atividades de vigilância e transporte de valores, que já possuem legislação específica.

É estabelecida multa administrativa de $\mathrm{R} \$ 500,00$ (quinhentos reais) por trabalhador prejudicado em caso de descumprimento da norma.

É concedida anistia aos débitos, penalidades e multas impostas com base em normas não compatíveis com a lei.

A proposição concede prazo de cento e vinte dias para a adequação dos contratos vigentes aos termos da nova lei, sendo que a vigência ocorrerá trinta dias após a publicação.

Tal prazo, acreditamos, é suficiente para que as partes interessadas tenham ciência das alterações e adeqüem seus contratos.

Destacamos, ainda, que a proposição é fruto de discussão com vários segmentos da sociedade. Tal discussão não está encerrada. Deve, outrossim, ser ampliada, a fim de aprimorar o texto da norma. Colocamo-nos, desde já, à disposição daqueles que queiram contribuir para a regulação dessa matéria, tão relevante para as relações de trabalho no Brasil.

Por considerarmos de alta relevância a regulamentação da terceirização, rogamos aos nobres Colegas pela aprovação deste Projeto de Lei.

Sala das Sessões, em de de 2004.

Deputado Sandro Mabel

2004.12234.999 
ANEXO 7 - Projeto de Lei $\mathbf{n}^{\circ}$ 1.621/2007 


\section{PROJETO DE LEI No , DE 2007}

\section{(Do Senhor Vicentinho)}

Dispõe sobre as relações de trabalho em atos de terceirização e na prestação de serviços a terceiros no setor privado e nas sociedades de economia mista.

\section{O CONGRESSO NACIONAL decreta:}

Art. $1^{\circ}$. A presente Lei dispõe sobre as relações de trabalho em atos de terceirização e na prestação de serviços a terceiros no setor privado e nas sociedades de economia mista.

Art. $2^{\circ}$. Para fins de aplicação desta lei, consideram-se os seguintes conceitos de terceirização, tomadora e prestadora de serviços:

I - terceirização é a transferência da execução de serviços de uma pessoa jurídica de direito privado ou sociedade de economia mista para outra pessoa jurídica de direito privado;

II - tomadora é a pessoa jurídica de direito privado ou sociedade de economia mista que contrata serviços de outra pessoa jurídica prestadora;

III - prestadora é a pessoa jurídica de direito privado que exerce atividade especializada e que, assumindo o risco da atividade econômica, contrata, assalaria e comanda a prestação de serviços para uma tomadora.

Art. $3^{\circ}$. É proibida a terceirização da atividade-fim da empresa.

$\S 1^{\circ}$ - Entende-se por atividade fim, o conjunto de operações, diretas e indiretas que guardam estreita relação com a finalidade central em torno da qual a empresa foi constituída, está estruturada e se organiza em termos de processo de trabalho e núcleo de negócios.

$\S 2^{\circ}$ - Na atividade fim da empresa não será permitida a contratação de pessoa jurídica, devendo tais atividades serem realizadas somente por trabalhadores diretamente contratados com vínculo de emprego.

Art. $4^{\circ} \mathrm{A}$ empresa que pretenda terceirizar serviços informará ao sindicato respectivo da sua categoria profissional, com no mínimo seis meses de antecedência, sobre os projetos de terceirização.

$\S$ único. No ato de comunicação dos projetos, a empresa deverá fornecer ao sindicato da categoria profissional, dentre outras, as seguintes informações:

I - os motivos da terceirização;

II - os serviços que pretende terceirizar;

III - o número de trabalhadores diretos e indiretos envolvidos na terceirização;

IV - a redução de custos pretendida;

$\mathrm{V}$ - os locais de prestação dos serviços;

VI - que prestadoras pretende contratar para executar os serviços, exceto empresas de economia mista, por terem regulamentação própria.

Art. $5^{\circ}$ No contrato de prestação de serviços firmado entre a tomadora e a prestadora deverá constar a especificação dos serviços a serem executados e seu prazo de duração.

Art. $6^{\circ}$ A tomadora deverá exigir da prestadora e manter sob sua guarda, para fins de controle e fiscalização, cópia dos seguintes documentos: 
a) comprovação do Registro da prestadora na Junta Comercial;

b) comprovação do capital social integralizado da prestadora, suficiente para garantir a satisfação dos direitos e créditos trabalhistas, inclusive na rescisão;

c) comprovação de entrega da Relação Anual de Informações Sociais (RAIS) pela prestadora;

d) Certidão Negativa de Débito Previdenciário (CND) pela prestadora;

e) comprovação da propriedade do imóvel-sede ou recibo referente ao último mês, relativo ao contrato de locação da prestadora;

f) inscrição da prestadora no Cadastro Nacional de Pessoas Jurídicas (CNPJ) da Secretaria da Receita Federal;

g) comprovação pela prestadora de regularidade do Fundo de Garantia por Tempo de Serviço (FGTS) expedida pela Caixa Econômica Federal;

h) certidão negativa de infrações trabalhistas pela prestadora, expedida pelos órgãos locais do Ministério do Trabalho e Emprego;

i) acordo coletivo ou convenção coletiva.

Parágrafo Único: Os itens d, g e h deverão ser entregues mensalmente pela prestadora.

Art. $7^{\circ}$ - Dependendo da natureza dos serviços contratados, a sua prestação poderá desenvolver-se nas instalações físicas da tomadora ou em outro local, respeitadas, em quaisquer das ipóteses, as seguintes exigências:

I - não haverá distinção de salário, jornada, benefícios, ritmo de trabalho e condições de saúde e de segurança entre os empregados da tomadora e os empregados da prestadora que atuem nas instalações físicas da tomadora ou em outro local por ela determinado;

II - a tomadora será responsável em garantir aos empregados da prestadora, enquanto estes estiverem a seu serviço, os gastos com o deslocamento, bem como, com as acomodações destinadas ao trabalhador terceirizado deslocado do lugar onde iniciou a prestação do serviço;

III - é vedado à tomadora manter empregado em atividade diversa daquela para a qual foi contratado pela prestadora;

IV - os empregados da prestadora não poderão ser subordinados ao comando disciplinar e diretivo da tomadora;

V - a tomadora não poderá exigir a pessoalidade na prestação de serviços.

Art. $8^{\circ}$ É proibida a contratação de prestadoras constituídas com a finalidade de fornecer mão-de-obra, ressalvados os casos de trabalho temporário, serviços de vigilância e asseio e conservação.

Art. $9^{\circ}$ - A tomadora é solidariamente responsável, independentemente de culpa, pelas obrigações trabalhistas, previdenciárias e quaisquer outras decorrentes do contrato de prestação de serviços, inclusive nos casos de falência da prestadora.

$\S 1^{\circ}$. A prestadora é obrigada a fornecer, mensalmente, à tomadora comprovação do pagamento dos salários, do recolhimento das contribuições previdenciárias e do FGTS, bem como cópia das respectivas guias de recolhimento, devendo tais informações e documentos serem fornecidos pela prestadora ou tomadora aos sindicatos das categorias profissionais sempre que por eles solicitados. 
$\S 2^{\circ}$. A tomadora assegurará o pagamento imediato de salários, $13^{\circ}$ salário, férias com o terço constitucional e recolhimento de FGTS, sempre que a prestadora deixar de cumprir estas obrigações com seus trabalhadores.

Art. 10. Haverá vínculo empregatício entre a tomadora e os empregados da prestadora, sempre que presentes os elementos previstos no artigo $3^{\circ}$ da Consolidação das Leis do Trabalho, que caracterizam a relação de emprego - ressalvados os casos que exigem concurso público para a sua admissão, sem prejuízo do previsto no caput e $\S 1^{\circ}$ do artigo $9^{\circ}$.

Art. 11. Será assegurado aos sindicatos das categorias profissionais representarem os empregados administrativa e judicialmente, na qualidade de substituto processual, com o objetivo de assegurar o cumprimento do disposto nesta Lei.

Art. 12. Será constituída Comissão formada por representantes das empresas prestadoras, contratadas e sindicatos de trabalhadores para acompanhamento dos contratos de prestação de serviços.

Art. 13. O descumprimento do disposto nesta Lei sujeita os infratores (tomador e prestador) ao pagamento de multa percentual de $10 \%$ (dez por cento) sobre o valor do contrato de terceirização em favor do trabalhador prejudicado, se movida por este Reclamação Trabalhista perante a Justiça do Trabalho.

$\S 1^{\circ}$. No caso de reincidência o valor percentual da multa será de $15 \%$ (quinze por cento).

$\S 2^{\circ}$. No caso de ações coletivas movidas pelo Ministério Público do Trabalho, entidades sindicais ou em caso auto de infração lavrado por Auditor Fiscal do Trabalho, a multa será cobrada por trabalhador prejudicado e revertida ao Fundo de Amparo do Trabalhador.

Art. 14. Os contratos de prestação de serviços em vigor na data da vigência desta Lei terão o prazo de noventa dias, a contar de sua publicação, para se adequar às exigências nela contidas, exceto a estabelecida no artigo $4^{\circ}$.

Art. 15. Esta Lei entra em vigor na data de sua publicação.

\section{JUSTIFICATIVA}

Este Projeto de Lei tem como objetivo a definição da terceirização, assegurando a dignidade no trabalho. Com base nas experiências vividas pelos trabalhadores e dirigentes sindicais, é que a Central Única dos Trabalhadores elaborou algumas premissas que foram transformadas em proposições na forma deste Projeto de Lei.

No Brasil, não existe uma legislação específica que regule a terceirização. A Súmula 331 do TST é hoje a principal referência jurídica no assunto. A referida Súmula estabelece que a contratação de mão-de-obra por empresa interposta é ilegal, à exceção do trabalho temporário, serviço de vigilância, conservação/limpeza e os serviços especializados ligados à atividade-meio da tomadora. Entretanto, cabe dizer que as decisões judiciais são contraditórias quanto à sua interpretação.

Nos últimos anos, a terceirização tem avançado das atividades de apoio para áreas habitualmente relacionadas à atividade principal da empresa.

A suposta redução de custos tem sido acompanhada muitas vezes de diversos problemas trabalhistas, entre os quais: redução de postos de trabalho; redução de remuneração e benefícios, incremento de jornadas; insalubridade; aumento de acidentes de trabalho; redução fraudulenta de custos, com a subordinação direta e pessoal do empregado terceirizado à empresa contratante; ausência de responsabilidade subsidiária e solidária da empresa contratante, entre outros. 
Tais premissas nos levam a concluir pela importância do Projeto de Lei ora apresentado. É sabido que a terceirização ao invés de proporcionar um bem, tem causado, em alguns casos, graves problemas no aspecto da qualidade e sobretudo nas condições de trabalho.

Nesse sentido é que nós acreditamos na sensibilidade e na responsabilidade dos parlamentares para que se cumpra a missão social do trabalho.

E essas são as razões pelas quais contamos com o apoio dos Ilustres Pares para a aprovação da presente proposição.

Sala das Sessões, em de julho de 2007.

Deputado Vicentinho

PT-SP 
ANEXO 8 - Projeto de Lei $\mathbf{n}^{\circ} \mathbf{6 . 8 3 2 / 2 0 1 0}$ 
(Do Sr. Paulo Delgado)

Dispõe sobre a contratação de serviços

terceirizados por pessoa de natureza jurídica

de direito privado.

Art. $1^{\circ}$ Os contratos de prestação de serviços terceirizados, assim considerados aqueles executados por uma contratada, pessoa jurídica especializada, para uma contratante pessoa jurídica ou física, serão pactuados na forma desta Lei.

Parágrafo único. Considera-se pessoa jurídica especializada aquela que possua conhecimento específico e utilize profissionais qualificados para a consecução de sua atividade.

Art. $2^{\circ} \mathrm{O}$ contrato de prestação de serviços terceirizados deverá possuir cláusulas com as seguintes disposições:

I. A especificação dos serviços a ser executados;

II. Prazo de vigência de, no máximo, cinco anos;

III. Comprovação, pela contratada a contratante, do cumprimento das obrigações trabalhistas relativas aos empregados que participarem da execução dos serviços, que devem ser individualmente identificados, e ainda o monitoramento do contrato pela contratante, em conformidade com o regulamento previsto no art. 12 ; e

IV. Resolução do contrato, quando identificado o inadimplemento das obrigações trabalhistas.

Parágrafo único. Será nula de pleno direito a cláusula contratual que proíba ou imponha condição a contratação de empregados da contratada pela contratante.

Art. $3^{\circ}$ Integrarão o contrato de prestação de serviços terceirizados os seguintes documentos comprobatórios da regularidade da contratada, dentre outros que possam ser exigidos pela contratante:

I. Registro como pessoa jurídica, na forma da lei;

II. Inscrição no Cadastro Nacional de Pessoa Jurídica - CNPJ do Ministério

da fazenda;

III. Alvará de localização e funcionamento;

IV. Comprovante de entrega da última Relação Anual de Informações Sociais - RAIS devida;

V. Certidão Negativa de Débito - CND ou certidão Positiva de Débitos com efeito negativo - CPD-EN, da Previdência Social;

VI. Certificado de regularidade do Fundo de Garantia do Tempo de Serviço - FGTS;

VII. Contrato Social atualizado, com capital social considerado, pela contratante, compatível com a execução do serviço.

Art. $4^{\circ} \mathrm{O}$ contrato de prestação de serviços terceirizados será regido pelas disposições gerais dos contratos, exceto se, na prestação de serviços, ficar configurada, judicialmente, relação de emprego, nos 
termos do caput do art. $3^{\circ}$ da Consolidação das Leis do Trabalho, aprovada pelo Decreto-lei ${ }^{\circ}$ 5.452, de $1^{\circ}$ de maio de 1943.

Art. $5^{\circ}$ A contratante será solidariamente responsável pelas obrigações e deveres trabalhistas durante o período e nos limites da execução do serviço contratado, inclusive se houver subcontratação de serviços, nos termos do art. $6^{\circ}$.

$\S 1^{\circ}$ A responsabilidade solidária transmudar-se-á para subsidiária se a contratante comprovar que na celebração e durante a vigência do contrato cumpriu o disposto nos arts. $2^{\circ}, 3^{\circ}$ e $7^{\circ}$, especialmente se houver rompimento do contrato nos termos do inciso IV do art. $2^{\circ}$.

$\S 2^{\circ}$ A imputação de responsabilidade solidária ou subsidiária refere-se ao pagamento de direitos e cumprimento de obrigações trabalhistas, sem gerar vínculo empregatício entre a contratante e o empregado da contratada.

Art. $6^{\circ}$ A contratada poderá subcontratar a realização de parte dos serviços terceirizados, desde que previsto no contrato originário firmado com a contratante, que deverá exercer, na subcontratação, a obrigação prevista no inciso III do art. $2^{\circ}$.

Parágrafo único. O contrato de subcontratação será regido pelas disposições desta lei, cabendo a contratada assumir todos direitos e obrigações de contratante.

Art. $7^{\circ}$ o local da prestação de serviços deverá ser especificado no contrato e, quando o serviço for executado em suas dependências, deverá a contratante:

I- manter ambiente de trabalho, inclusive equipamentos e instalações, em condições adequadas ao cumprimento, pela contratada, das normas de segurança e saúde no trabalho; e

II- assegurar aos empregados da contratada, se esta não o fizer, o acesso às instalações disponíveis a seus empregados, no que se refere a alimentação, transporte, atendimento ambulatorial e condições sanitárias.

Art. $8^{\circ}$ Aos empregados da empresa contratada serão assegurados os direitos instituídos em convenção coletiva celebrada pelo sindicato representativo da categoria profissional respectiva.

Art. $9^{\circ}$ A contratação de prestação de serviços terceirizados com empresa não especializada configura locação e fornecimento de mão-de-obra, improtando na existência de relação de emprego entre os empregados contratados e a contratante, salvo nos casos de serviços terceirizados regidos por lei própria.

Art. $10^{\circ} \mathrm{O}$ descumprimento do disposto no parágrafo único do art. $1^{\circ}$, nos arts. $2^{\circ}, 3^{\circ}$ e caput do art. $6^{\circ}$, implicará a aplicação de multa administrativa, à contratante e a contratada, no valor de $\mathrm{R} \$ 1.000,00$ (um mil reais) por trabalhador envolvido, dobrado na reincidência.

Parágrafo único. O descumprimento das obrigações previstas no art. $7^{\circ}$ implicará a aplicação de multa administrativa, a contratante, no valor de $\mathrm{R} \$ 500,00$ (quinhentos reais) por trabalhador envolvido, dobrado na reincidência.

Art. $11^{\circ} \mathrm{O}$ processo de fiscalização, de autuação e de imposição de multas regerse-á pelo disposto no Título VII da Consolidação das Leis do Trabalho.

Art. $12^{\circ}$ Caberá ao Ministério do trabalho e Emprego editar normas regulamentares necessárias a execução desta Lei, assim como instruções a fiscalização.

Art. $13^{\circ}$ Esta Lei entra em vigor na data de sua publicação.

\section{JUSTIFICATIVA}


Há um grave descompasso entre a realidade da terceirização, fenômeno irreversível de organização da produção, e sua regulamentação pela legislação trabalhista. $O$ que preocupa a trabalhadores, empresários, Ministério do Trabalho e todos os que se preocupam com a modernização e segurança das relações de trabalho e emprego.

O artigo 170, parágrafo único, da Constituição da República é claro ao assegurar o livre exercício de qualquer atividade econômica e, por conseguinte, de qualquer trabalho, ofício ou profissão.

Nesse mesmo sentido, o artigo 421 do Código Civil assegura a liberdade de contratar, disposição esta fundada no princípio da autonomia da vontade. É de se destacar, ainda, que os artigos 593 e seguintes do Código Civil disciplinam e regulamentam a prestação de serviços, assegurando, dentre outros aspectos, que "toda a espécie de serviço ou trabalho lícito, material ou imaterial, pode ser contratada mediante retribuição".

Ocorre que a norma constitucional e os dispositivos do Código Civil vêm sendo ultrapassados por súmulas, portarias, enunciados e autuações de órgãos públicos que, sistematicamente, desconsideram os princípios da livre iniciativa, da autonomia da vontade e da licitude das atividades empresariais.

Pode-se dizer, portanto, que são abusivas, ilegais e inconstitucionais as ações trabalhistas que tenham por base a definição do que sejam os objetivos e as atividades principais e secundárias de uma empresa, bem como aquelas passíveis de terceirização.

Em verdade, essas ações trabalhistas abusivas, ilegais e inconstitucionais são decorrentes do fato de que o Brasil, até o momento, não regulamentou, por lei específica, a contratação de serviços terceirizados. Esse quadro revela-se extremamente preocupante, haja vista que é cada vez menor o número de empresas que mantêm as tradicionais estruturas verticalizadas, realizando todas as tarefas inerentes ao processo produtivo.

A atual complexidade dos arranjos produtivos e a busca cada vez maior por especialização e produtividade criaram novas ferramentas de gestão empresarial, nova divisão do trabalho e nova tendência no mercado. É fato, a maioria das empresas compra de outras empresas grande parte dos itens que compõem seus produtos finais.

Trata-se, assim de uma verticalização virtual. Isso vale para todos os setores da atividade econômica.

Logo, a inexistência de uma lei que discipline, de forma contemporânea, a terceirização de atividades e os correspondentes mecanismos de controle empurra o Brasil para uma terceirização mal feita. Até agora, é apenas o enunciado 331 do TST que, suprindo o indesejável vácuo legal, regulamenta, sob o prisma do Direito do Trabalho, o processo de terceirização.

A conseqüência imediata é o engessamento do mercado de trabalho, que limita sua expansão, favorecendo o desemprego e a informalidade.

Preocupa ainda o inchaço cada vez maior dos quadros de pessoal das empresas estatais e dos órgãos públicos bem como a existência de conflitos desnecessários em virtude da apontada inexistência de um marco regulatório que crie a relação terceirizada protegida, tanto para o trabalhador como para as empresas envolvidas.

Com o objetivo de colaborar para o combate a terceirização aviltante e fixar limites legais que impeçam a fiscalização arbitrária - eliminando a insegurança jurídica que gera o impagável passivo trabalhista propõe-se este Projeto de Lei sobre a terceirização protegida em torno dos seguintes princípios, que passamos a elencar: 
1- Cuidado com o parceiro: a terceirização deve ser vista como uma parceira entre as empresas, devendo ser plenamente esclarecidas e definidas as responsabilidades de cada uma das partes. Portanto, a tomadora deverá selecionar os seus possíveis parceiros, conferindo a sua qualificação empresarial para o serviço;

2- Segurança jurídica: deve-se sair do campo da Jurisprudência e ir para o campo da lei da livre possibilidade de contratação, Lei da terceirização protegida (enunciados e leis sobre o assunto: 239, $331 \mathrm{e}$ leis $6.019 ; 70102)$. O objetivo dessa lei deve ser o seguinte: decidindo terceirizar que o faça bem feito, protegendo os direitos trabalhistas e previdenciários. É preciso zelar pelo cumprimento do contrato e assegurar o pleno respeito à competência da Justiça do Trabalho para efeito de reconhecimento de vínculo empregatício. A nova lei busca, ainda, estabelecer requisitos mínimos para a qualificação de empresas terceirizadas: idoneidade, capital mínimo, especialização, legalidade fiscal e tributária;

3- Responsabilidade subsidiária: definir as responsabilidades do contratante sobre o contratado, preservando a autonomia empresarial. Sinalizar com a possibilidade de coadministração do contrato e responsabilidade subsidiária (a responsabilidade solidária pura e simples livra a contratada da repartição de riscos resultados de sua própria inépcia, quando houver).

4- Proteção dos direitos dos trabalhadores: fiscalização ativa do cumprimento das Normas Regulamentadoras - NR's pelos órgãos competentes (DRT, MPT, Sindicatos) com objetivo de melhorar o ambiente de trabalho, e de proteção à saúde e segurança do trabalhador e reverter os índices de acidentes dos terceirizados em relação aos trabalhadores do quadro próprio, estabelecer novos patamares para renovação do contrato e remuneração.

5- Especialização e eficiência: permitir a terceirização de atividades que sejam inerentes e necessárias para a produção das empresas, guiar a terceirização por critérios de qualificação empresarial, norteada pelos seguintes princípios: contratação para eficiência, eficácia, e segurança. Manter o controle de gestão, decisão e competência da Contratante. Pleno cumprimento das exigências legais pela Contratada. Uso de tecnologias compatíveis. Confiabilidade, respeito e senso de responsabilidade entre contratantes e contratados tanto na relação entre trabalhadores das empresas como entre seus empresários (padrão de qualidade, treinamento, empreendedorismo, investimento em tecnologia e aperfeiçoamento, cálculo adequado e justo da estrutura de preços.

Atenção as reivindicações sindicais diminuindo atritos. Buscar a melhor qualificação da mão-de-obra nessa que é uma nova e promissora área de expansão do mercado de trabalho.

6- Geração de empregos e de receita pública. A terceirização orientada pelos princípios acima enunciados contribuirá para maior geração de empregos - e empregos formais - o que ajudará a combater a extensa informalidade que domina o mercado de trabalho.

Sala das Sessões 23 de fevereiro de 2010.

Deputado PAULO DELGADO 
ANEXO 9 - Sentença Rodríguez x Cía. Embotelladora de Argentina S.A. 
Buenos Aires, abril 15 de 1993.

Considerando: $1^{\circ}$. Que contra la sentencia de la sala VI de la Cámara Nacional de Apelaciones del Trabajo que, al confirmar parcialmente la de primera instancia, hizo extensiva la condena de pago de salarios e indemnizaciones motivadas en la ruptura de la relación laboral habida entre el actor y la demandada principal, la codemandada dedujo el recurso extraordinario federal cuya denegación dio origen

a esta

queja.

La cámara consideró que la apelante no desvirtuó los fundamentos del fallo de primera instancia para extender la responsabilidad, sino que 'por el contrario, ellos son claramente corroborantes de la segmentación de su proceso productivo, proceder que bien puede responder a una estrategia empresarial pero, de ningún modo, puede servir de argumento válido para declinar la responsabilidad solidaria que en el marco de la ley de contrato de trabajo y de la realidad le cabe en virtud de la segregación de funciones que le son propias o con las que no concibe un acabado cumplimiento de su giro comercial, a otras empresas', con cita del art. 30 de la ley de contrato de trabajo.

$2^{\circ}$. Que el art. 30 citado establece, en lo pertinente, la responsabilidad solidaria de 'quienes ... contraten o subcontraten, cualquiera sea el acto que le dé origen, trabajos o servicios correspondientes a la actividad normal y específica propia del establecimiento ...' por las obligaciones laborales del contratista o subcontratista.

Con ello se persigue evitar la interposición de 'hombres de paja' entre un trabajador y su verdadero empleador y realizar los ponderables fines tuitivos del ordenamiento laboral (confr. antecedentes parlamentarios de la ley 20.744 (DT, 1976, 238), opinión del senador Pennisi, Diario de Sesiones de la Cámara de Senadores del Honorable Congreso de la Nación, año 1974, t. I, ps. 480/481).

$3^{\circ}$. Que en el sub lite, el actor se hallaba vinculado laboralmente a Compañía Embotelladora Argentina S. A., empresa dedicada, según surge de la sentencia de primera instancia, a la fabricación, venta y distribución de gaseosas de la línea Pepsi en la Capital Federal y Gran Buenos Aires.

La recurrente se dedica a elaborar los concentrados de las bebidas gaseosas, vendiéndolos a su vez a otras empresas. Compañía Embotelladora compraba a Pepsi Cola Argentina S. A. C. I. esos extractos, elaboraba el producto final, $\quad$ y lo vendía Estas circunstancias relativas a la actividad comercial normal y real de ambas empresas no se encuentran controvertidas en la causa. Por lo demás, también se tuvieron por acreditadas en otra análoga, sentenciada el 12/9/91 por la sala II de la CNTrab. (autos 'Taboada c. Compañía Embotelladora Argentina S. A. s/ despido'), en la que se pretendía la misma declaración de solidaridad a la que se hizo lugar en el sub lite. La cámara juzgó allí que 'Pepsi ha elegido sólo producir concentrados concluyendo allí la etapa de elaboración industrial y luego comercializar ese producto a quienes se encarguen de fabricar la bebida 
gaseosa'. Y más adelante, que 'de acuerdo a los datos suministrados por el informe pericial contable, Compañía Embotelladora Argentina S. A. adquiría los concentrados por un precio determinado y luego a partir de ellos fabricaba la gaseosa que, aunque por razones comerciales y de identificación del producto obviamente correspondiera a la marca de la licenciataria originaria, no aparecía ligada en su resultado, precio y demás consecuencias a la fabricante del concentrado, surgiendo nítidamente la separación entre ambas explotaciones y sumándose a ello que su actuación sólo se limitaba a un ámbito geográfico -Gran Buenos Aires y Capital Federal-'.

$4^{\circ}$. Que la recurrente, al expresar agravios ante la Cámara sostuvo, sobre la base del peritaje no impugnado en lo pertinente, que su actividad normal se limitaba a fabricar el concentrado, sin vincularse en absoluto con la fabricación y ulterior distribución de las gaseosas, realizada por una empresa jurídicamente independiente, cual es Compañía Embotelladora Argentina S. A. A su vez, afirmó, sin que haya sido controvertido por la contraparte, que Pepsi 'no participa en manera alguna en la distribución, dirección o supervisión de la actividad desarrollada por Compañía Embotelladora Argentina'. Por ello, consideró que no había mediado la contratación o subcontratación prevista por el art. 30 de la ley de contrato de trabajo. En apoyo de esta consideración, argumentó que no obstaba a ello el hecho de que el objeto social de Pepsi estuviera formulado en términos amplios ('fabricación, industrialización, destilación y/o comercialización de toda clase de concentrados y/o licores y/o bebidas alcohólicas o no; compra, venta, consignación, fabricación, importación, exportación, transporte, almacenaje y distribución de productos y mercaderías de todo tipo y clase y materias primas industrializadas o no...', confr. el estatuto obrante a fs. 194), entendiendo que la norma laboral no se refiere al objeto sino a la actividad social, de acuerdo a la distinción efectuada en la ley de sociedades (art. 19, ley 19.550).

$5^{\circ}$. Que la cámara se limitó a afirmar que Pepsi había segmentado su proceso productivo y segregado funciones que le son propias, sin considerar la negativa que al respecto planteó la recurrente, ni la prueba pericial en que la fundó. Esto basta para descalificar la sentencia como acto de imparcial administración de justicia, por tratarse de una cuestión esencial para la solución del pleito.

Por otra parte, la cámara omitió examinar la distinción propuesta por la apelante entre objeto y actividad social, de relevancia decisiva para resolver esta causa. $6^{\circ}$. Que, en las condiciones expuestas, la sentencia impugnada omite una apreciación crítica de los elementos relevantes de la litis en el punto discutido (Fallos 303:1258, entre muchos otros) y se base en pautas de excesiva latitud (confr. 'Bariain, Narciso T. c. Mercedes Benz Argentina S. A.', pronunciamiento del 7/10/86, entre otros) con grave lesión al derecho de defensa en juicio de la recurrente, por lo que debe descalificársela como acto judicial válido.

$7^{\circ}$. Que la solución del presente caso puede contribuir al desarrollo del derecho sobre la materia, en la que 
están involucradas modalidades de la contratación comercial que posiblemente tendrán considerable trascendencia para la economía del país. La cuestión a decidir reviste, por tanto, significativa importancia para el desarrollo del comercio interno e internacional, suscitando cuestión federal trascendente (confr. art. 67, inc. 12 de la Constitución Nacional y art. 280, Cód. Procesal). Procede, por ello, y con el propósito de afianzar la seguridad jurídica, que esta Corte resuelva el fondo del asunto y decida, en uso de la facultad que le concede el art. 16 de la ley 48, si un contrato de las características del que ocasiona esta controversia se encuentra subsumido en la norma del art. 30 de la ley de contrato de trabajo, a fin de poner un necesario quietus en la evolución de las diversas tendencias jurisprudenciales que distan de ser pacíficas, como surge de numerosos pronunciamientos del fuero laboral.

$8^{\circ}$. Que las gravísimas consecuencias que derivan de la extensión de la responsabilidad patrimonial a terceros ajenos en principio a la relación sustancial que motivó la reclamación de autos, requiere la comprobación rigurosa de los presupuestos fácticos establecidos en el art. 30 de la ley de contrato de trabajo. Esta exigencia de un escrutinio estricto de los recaudos legales que condicionan la obligación de garantía de un tercero, tiene su fundamento en la fuerte presunción de inconstitucionalidad que brota de toda norma -o de su interpretación- que obligue al pago de una deuda en principio ajena, solución que se aparta de la regla general consagrada por los arts. 1195 y 1713 del Cód. Civil y 56 de la ley 19.550, vinculados, en este aspecto, con la intangibilidad del patrimonio establecida por el art. 17 de la Constitución Nacional.

$9^{\circ}$. Que no corresponde la aplicación del art. 30 de la ley de contrato de trabajo toda vez que un empresario suministre a otro un producto determinado, desligándose expresamente de su ulterior procesamiento, elaboración y distribución. Este efecto se logra en la práctica comercial por contratos de concesión, distribución, franquicia y otros que permiten a los fabricantes o, en su caso, a los concedentes de una franquicia comercial, vincularse exclusivamente con una empresa determinada sin contraer riesgo crediticio alguno por las actividades de esta última, que actúa en nombre propio y a su riesgo. Esta finalidad económica de la referida contratación comercial se frustraría si el derecho aplicable responsabilizara sin más a los concedentes por las deudas laborales de las concesionarias, con perjuicio para la economía nacional por las indudables repercusiones que ello tendría en las inversiones, en contratos de este tipo. Esta Corte no puede omitir la consideración de estas circunstancias pues como reiteradamente ha juzgado 'no debe prescindirse de las consecuencias que naturalmente derivan de un fallo toda vez que constituye uno de los índices más seguros para verificar la razonabilidad de la interpretación y su congruencia con el sistema en que está engarzada la norma' (Fallos 302:1284).

Este entendimiento resulta válido por cuanto deja plenamente vigente la debida y severa tutela de los derechos del trabajador en los supuestos en que aquella contratación sea tan solo la apariencia para evadir la responsabilidad laboral (arts. 14 y 31, ley de contrato de trabajo). 10. Que el art. 30 de la ley de contrato de trabajo contempla supuestos distintos de los que son materia de 
recurso. La norma comprende las hipótesis en que un empresario encomienda a un tercero la realización de aspectos o facetas de la misma actividad que desarrolla en su establecimiento. Son supuestos en los que se contrata prestaciones que completan o complementan la actividad del propio establecimiento, esto es, 'la unidad técnica o de ejecución destinada al logro de los fines de la empresa, a través de una o más explotaciones' (art. $6^{\circ}$, ley de contrato de trabajo).

En los contratos de concesión, distribución y los demás mencionados, la actividad normal del fabricante o concedente excluye las etapas realizadas por el distribuidor o concesionario, por lo que no existe contratación de servicios en los términos del art. 30 de la ley de contrato de trabajo.

11. Que no media en el caso la contratación o subcontratación prevista en el art. 30 de la ley de contrato de trabajo, pues los trabajos y servicios de Compañía Embotelladora no corresponden a la actividad normal y específica de Pepsi Cola Argentina S. A. C. I., cual es la fabricación de los concentrados. No obsta a ello la lata formulación del objeto social, que ordinariamente tiene por fin asegurar la capacidad y el ámbito de actuación eventual de la persona jurídica, pues el art. 30 citado precedentemente no se refiere al objeto ni a la capacidad societaria sino a la actividad real propia del establecimiento. Las figuras delegativas previstas por aquella norma, en lo pertinente, contratación y subcontratación, son inherentes a la dinámica del giro empresarial y, por ello, no cabe examinar su configuración con respecto al objeto social.

En el caso no se ha probado vinculación jurídica entre las accionadas. Tampoco que Pepsi tuviera participación de algún tipo en la actividad de Compañía Embotelladora. El solo hecho de que la primera provea a la segunda materia prima no compromete, por si mismo, su responsabilidad solidaria por las obligaciones laborales de la segunda en los términos del art. 30 de la ley de contrato de trabajo. Para que nazca aquella solidaridad es menester que una empresa contrate o subcontrate servicios que complementen o completen su actividad normal. Debe existir una unidad técnica de ejecución entre la empresa y su contratista, de acuerdo a la implícita remisión que hace la norma en cuestión al art. $6^{\circ}$ del mismo ordenamiento laboral. Esta unidad no ha sido probada en el presente caso.

12. Que tampoco se ha probado en el caso la concurrencia de las circunstancias que habilitan la aplicación del art. 31 de la ley de contrato de trabajo, por lo que no corresponde que esta Corte se pronuncie al respecto. Por lo demás, las relaciones comerciales que habitualmente tienen lugar en estos casos no consisten en el control de la concesionaria -o en su caso, la beneficiaria de la franquicia- por parte de la concedente, sino que tienden a lograr una mutua colaboración. A su vez, los servicios que la concedente presta no implican, de ordinario, la asunción de riesgo del negocio propio del concesionario ni la toma de decisiones laborales relativas a los empleados de éste. En consecuencia, corresponde hacer lugar a la queja, declarar procedente el recurso extraordinario y 
decidir el fondo del asunto de conformidad con lo expuesto en las consideraciones que anteceden, pues media en el caso el nexo necesario y directo entre lo debatido y resuelto y las garantías constitucionales que se dicen vulneradas (art. 15, ley 48).

Por ello, se hace lugar a la queja, se declara procedente el recurso extraordinario y se rechaza la demanda respecto de Pepsi Cola Argentina S. A. C. I. (art. 16, ley 48). - Ricardo Levene (h.). - Mariano A. Cavagna Martínez. - Carlos S. Fayt (en disidencia). - Augusto C. Belluscio (en disidencia). - Enrique S. Petracchi (en disidencia). - Antonio Boggiano. - Julio S. Nazareno (en disidencia). - Rodolfo C. Barra. Disidencia del doctor Belluscio.

Considerando: $1^{\circ}$. Que contra la sentencia de la sala VI de la CNTrab. que, al confirmar parcialmente la de primera instancia, hizo extensiva la condena de pago de salarios e indemnizaciones motivadas en la ruptura de la relación laboral habida entre los actores y demandada principal, la codemandada dedujo el recurso extraordinario federal cuya denegación dio origen a la queja en examen.

Para así decidir, en lo que interesa, el a quo consideró que la apelante no logró rebatir los fundamentos invocados en el fallo de primera instancia para extender la responsabilidad, 'sino por el contrario, ellos son claramente corroborantes de la segmentación de su proceso productivo, proceder que bien puede responder a una estrategia empresarial pero, de ningún modo, puede servir de argumento válido para declinar la responsabilidad solidaria que en el marco de la ley de contrato de trabajo y de la realidad le cabe la virtud de la segregación de funciones que le son propias con las que no se conciben un acabado cumplimiento de su giro comercial, a otras empresas', con cita del art. 30 de la ley de contrato de trabajo (confr. fs. 334 vta. de los autos principales, foliatura que se mencionará en lo sucesivo).

$2^{\circ}$. Que la recurrente se agravia con sustento de la doctrina de la arbitrariedad y formula diversas tachas; cada una de ellas constituye una causal autónoma de modo que la sola aceptación de una bastaría para decidir la apertura y el acogimiento de la apelación deducida, no obstante que las cuestiones discutidas en la causa son, en principio, ajenas por su naturaleza a la esfera del mencionado recurso (Fallos 298:24; 299:104 y otros muchos, entre ellos 'Farrell, Martín D. c. Universidad de Belgrano', F.532. XXII, sentencia del 2/10/90, considerando segundo).

$3^{\circ}$. Que la prescindencia de circunstancias concretas del caso, la omisión de una adecuada exégesis de las normas invocadas y el apoyo en pautas de excesiva latitud, redundan en el menoscabo de la adecuada fundamentación exigible a los fallos judiciales. Es en este punto en el que reside, a criterio del tribunal, el aspecto verdaderamente relevante del debate vinculado con la apelación sub examine. En efecto, todo el peso de la argumentación efectuada por el tribunal a quo giró en torno a la denominada 
'segmentación' del proceso productivo de la codemandada, sin formular mención alguna acerca de los presupuestos en que -de acuerdo a los términos de la norma citada en la sentencia- la solidaridad se impondría: cesión total o parcial del establecimiento o explotación, contratación o subcontratación de trabajos o servicios correspondientes a la actividad normal y específica propia del establecimiento, dentro o fuera de su ámbito (art. 30, ley de contrato de trabajo), y sin examinar si las circunstancias del caso encuadraban en dicha normativa.

Tales consideraciones se imponían a fin de brindar a la apelante adecuada respuesta a los planteos que formuló en defensa de sus derechos. Ello es así, habida cuenta de los términos sostenidos en su expresión de agravios ante la cámara al apelar la decisión de primera instancia en los que sostuvo -en relación al tema que motivó sus impugnaciones ante esta Corte- no menos de cuatro argumentaciones relacionadas con el objeto social, la actividad específica de la empresa, las pruebas rendidas en la causa y la interpretación de las normas de la ley de contrato de trabajo que, en su opinión, avalaban su postura. Ninguna de ellas fue examinada por el a quo.

$4^{\circ}$. Que, en las condiciones expuestas, la sentencia impugnada omite una apreciación crítica de los elementos relevantes de la litis en el punto discutido (Fallos: 303:1258, entre muchos otros) y se base en pautas de excesiva latitud (confr. 'Bariain, Narciso T. c. Mercedes Benz Argentina S. A.', pronunciamiento del 7/10/86, ente muchos otros) con grave lesión del derecho de defensa juicio de la impugnante, por lo que debe descalificarse carácter de acto judicial válido -en cuanto fue motivo de agravios- pues media la relación directa e inmediata requerida por la ley 48 para la procedencia de la vía extraordinaria.

Por ello, se declara procedente el recurso extraordinario y la queja interpuestos, y se deja parcialmente sin efecto la sentencia. Con costas. Vuelvan los autos al tribunal de origen para que, por quien corresponda, proceda a dictar nuevo pronunciamiento. - Augusto C. Belluscio.

Disidencia de los doctores Fayt, Petracchi y Nazareno.

Considerando: Que el recurso extraordinario, cuya denegación motivó la presente queja, es inadmisible (art. 280, del Cód. Procesal).

Por ello, se desestima la queja. Declárase perdido el depósito de fs. 1. - Carlos S. Fayt. - Enrique S. Petracchi. - Julio S. Nazareno 